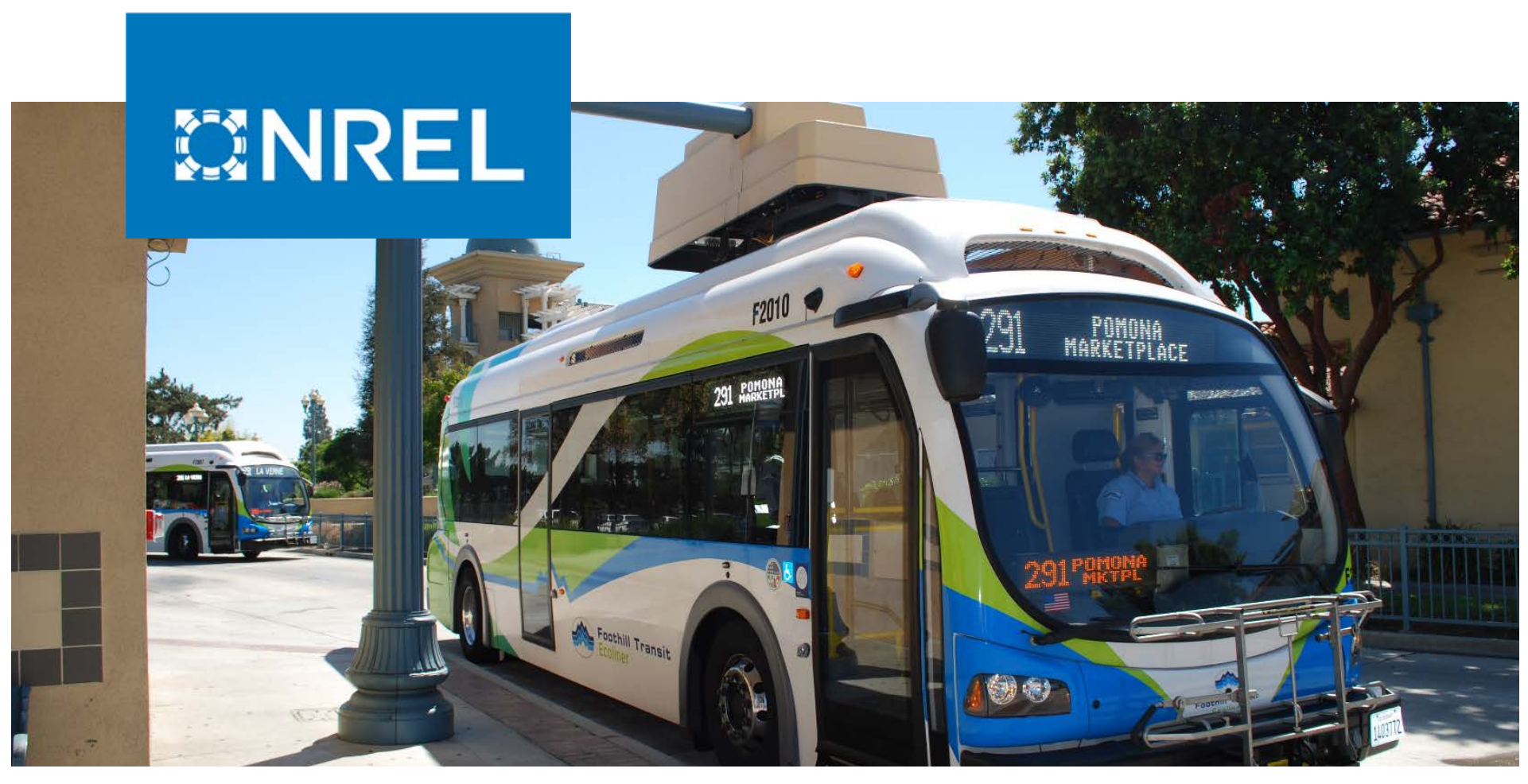

\title{
Foothill Transit Battery Electric Bus Evaluation: Final Report
}

Matthew Jeffers and Leslie Eudy

National Renewable Energy Laboratory

NREL is a national laboratory of the U.S. Department of Energy Office of Energy Efficiency \& Renewable Energy

Operated by the Alliance for Sustainable Energy, LLC

This report is available at no cost from the National Renewable Energy Laboratory (NREL) at www.nrel.gov/publications.

\section{Technical Report}

NREL/TP-5400-80022

June 2021 


\section{GHREL}

\section{Foothill Transit Battery Electric Bus Evaluation: Final Report}

Matthew Jeffers and Leslie Eudy

National Renewable Energy Laboratory

\section{Suggested Citation}

Jeffers, Matthew and Leslie Eudy. 2021. Foothill Transit Battery Electric Bus Evaluation: Final Report. Golden, CO: National Renewable Energy Laboratory. NREL/TP-540080022. https://www.nrel.gov/docs/fy21osti/80022.pdf.

NREL is a national laboratory of the U.S. Department of Energy Office of Energy Efficiency \& Renewable Energy Operated by the Alliance for Sustainable Energy, LLC

This report is available at no cost from the National Renewable Energy Laboratory (NREL) at www.nrel.gov/publications.

Contract No. DE-AC36-08GO28308
Technical Report NREL/TP-5400-80022 June 2021

National Renewable Energy Laboratory 15013 Denver West Parkway Golden, CO 80401 303-275-3000 • www.nrel.gov 


\section{NOTICE}

This work was authored by the National Renewable Energy Laboratory, operated by Alliance for Sustainable Energy, LLC, for the U.S. Department of Energy (DOE) under Contract No. DE-AC36-08GO28308. Funding provided by the California Air Resources Board. The views expressed herein do not necessarily represent the views of the DOE or the U.S. Government.

This report is available at no cost from the National Renewable Energy Laboratory (NREL) at www.nrel.gov/publications.

U.S. Department of Energy (DOE) reports produced after 1991 and a growing number of pre-1991 documents are available free via www.OSTI.gov.

Cover Photo by Leslie Eudy: NREL 35803.

NREL prints on paper that contains recycled content. 


\section{Acknowledgments}

This evaluation at Foothill Transit would not have been possible without the support and cooperation of many people. The authors thank the following individuals:

\section{California Air Resources Board (CARB)}

Yachun Chow

Jennifer Lee

Jing Guo

Bo Yang

U.S. Department of Energy's National Renewable Energy Laboratory (NREL)

Matthew Post

\section{Foothill Transit}

Doran Barnes

Roland Cordero

Andrew Papson (former Foothill Transit staff)

Jon House

Luis Renderos

Ritta Merza (former Foothill Transit staff)

\section{Proterra}

Mike Finnern

Derrick Allen

Sam Sperling

Unless otherwise noted, all photos by L. Eudy, NREL 


\section{List of Acronyms}

$\begin{array}{ll}\text { AITC } & \text { Azusa Intermodal Transit Center } \\ \text { ATA } & \text { American Trucking Associations } \\ \text { BEB } & \text { battery electric bus } \\ \text { BTM } & \text { battery thermal management } \\ \text { CARB } & \text { California Air Resources Board } \\ \text { CNG } & \text { compressed natural gas } \\ \text { dge } & \text { diesel gallon equivalent } \\ \text { DOE } & \text { U.S. Department of Energy } \\ \text { ESS } & \text { energy storage system } \\ \text { EVSE } & \text { electric vehicle supply equipment } \\ \text { FCEB } & \text { fuel cell electric bus } \\ \text { gge } & \text { gasoline gallon equivalent } \\ \text { GVWR } & \text { gross vehicle weight rating } \\ \text { hp } & \text { horsepower } \\ \text { HVAC } & \text { heating, ventilation, and air conditioning } \\ \text { KMBRC } & \text { kilometers between roadcalls } \\ \text { MBRC } & \text { miles between roadcalls } \\ \text { mpdge } & \text { miles per diesel gallon equivalent } \\ \text { mpgge } & \text { miles per gasoline gallon equivalent } \\ \text { mph } & \text { miles per hour } \\ \text { NABI } & \text { North American Bus Industries (now part of New Flyer) } \\ \text { NREL } & \text { National Renewable Energy Laboratory } \\ \text { OEM } & \text { original equipment manufacturer } \\ \text { O\&M } & \text { operations and maintenance } \\ \text { PMI } & \text { preventive maintenance inspection } \\ \text { psi } & \text { pounds per square inch } \\ \text { PTC } & \text { Pomona Transit Center } \\ \text { rpm } & \text { revolutions per minute } \\ \text { SCE } & \text { Southern California Edison } \\ \text { scf } & \text { standard cubic feet } \\ \text { SI } & \text { International System of Units } \\ \text { SOC } & \text { state of charge } \\ \text { TOU } & \text { time of use } \\ \text { VMRS } & \text { Vehicle Maintenance Reporting Standards } \\ \text { ZEB } & \text { zero-emission bus } \\ & \end{array}$




\section{Executive Summary}

This report summarizes results of a battery electric bus (BEB) evaluation at Foothill Transit, located in Southern California. Foothill Transit began a demonstration of three Proterra BEBs in October 2010 to evaluate the battery technology and determine if the BEBs could meet Foothill Transit's service requirements. Since that pilot project, the agency has added 31 BEBs to its fleet. Foothill Transit is collaborating with the California Air Resources Board (CARB) and the U.S. Department of Energy's (DOE's) National Renewable Energy Laboratory (NREL) to evaluate the buses in revenue service. The focus of the evaluation is to compare performance and cost of the BEBs to that of conventional technology in similar service and track progress over time.

Each NREL evaluation tracks data and performance results for a specific transit agency operating a specific manufacturer's technology design. Results from different manufacturer designs will vary and are not necessarily representative of a specific technology. Results will also vary from agency to agency and even between operating facilities within the same agency.

Foothill Transit operates BEBs at both its operation and maintenance facilities: Pomona and Arcadia. The BEBs in service at both locations are composite-body buses built by Proterra. The BEBs at the Pomona facility are fast-charge buses that use a high-powered overhead charger located at a transit center along the scheduled BEB route. NREL's evaluation covers a fleet of 12 35-ft fast-charge BEBs (identified in the report as BEB 35FC) and two 40-ft fast-charge BEBs (BEB 40FC). NREL collects data on a fleet of eight 40-ft North American Bus Industries (NABI) compressed natural gas (CNG) buses at Pomona for a baseline comparison. The BEBs operating out of the Arcadia facility are 40-ft extended-range buses (BEB 40E2) primarily charged by plugging in at the depot, but are also capable of fast charging using the overhead charger like the Pomona BEBs. The baseline CNG fleet for Arcadia includes 14 40-ft New Flyer buses. This report summarizes the results of the BEB and baseline fleets through December 2020.

The COVID-19 pandemic resulted in the need to reduce service during shutdowns. In March 2020 , Foothill Transit reduced service to about $70 \%$ of normal operation. The agency increased service up to $95 \%$ in late June. During this period, the BEB 35FC and BEB 40FC fleets at Pomona were used sparingly and did not accumulate mileage at the same rate as before. Issues with the buses and downtime for the fast-charge station further reduced use of these buses through the end of 2020. This resulted in significantly lower mileage accumulation for the BEBs, which has a noticeable effect on analyses that use mileage for calculations. The level of service in 2020 is not representative of normal fleet operations.

\section{Pomona Results Summary}

NREL began collecting data on the BEB 35FC fleet in April 2014 and on the BEB 40FC fleet in January 2017. The data collection on the CNG buses began in October 2014. Table ES-1 provides a summary of results for several categories of data presented in this report from the start date of each fleet through December 2020. Since being placed into service, the BEB 35FC fleet has traveled more than 1.7 million miles, and the BEB 40FC fleet has traveled more than 153,000 miles. Overall, the average monthly mileage per bus during the evaluation period was 
1,885 miles for the BEB 35FC fleet and 1,594 miles for the BEB 40FC fleet. The CNG buses accumulated 4,606 miles per month, on average - significantly more than the BEBs. This difference is the expected result of the scheduled operation of these fleets. The BEBs are operated primarily on Line 291 and the CNG buses are randomly dispatched on all routes out of the Pomona Operations and Maintenance facility, including express and commuter routes that have much higher average speeds.

Table ES-1. Summary of Evaluation Results, Pomona (Fast-Charge BEBs)

\begin{tabular}{|c|c|c|c|}
\hline Data Item & BEB 35FC & BEB 40FC & CNG \\
\hline Number of buses & 12 & 2 & 8 \\
\hline Model year & 2014 & 2016 & 2014 \\
\hline Data period & $\begin{array}{l}4 / 2014- \\
12 / 2020\end{array}$ & $\begin{array}{l}1 / 2017- \\
12 / 2020\end{array}$ & $\begin{array}{c}10 / 2014- \\
12 / 2020\end{array}$ \\
\hline Number of months & 81 & 48 & 75 \\
\hline Total mileage in data period & $1,772,084$ & 153,005 & $2,763,746$ \\
\hline Average monthly mileage per bus & 1,885 & 1,594 & 4,606 \\
\hline Availability ( $85 \%$ is target) & 80.6 & 76.1 & 94.0 \\
\hline Average speed, including stops (mph) & 10.6 & 10.6 & 17.6 \\
\hline Fuel economy (BEB in kWh/mile, CNG in mpgge ${ }^{a}$ ) & 2.15 & 2.10 & 3.74 \\
\hline Fuel economy $\left(\mathrm{mpdge}^{\mathrm{b}}\right)$ & 17.47 & 17.96 & 4.29 \\
\hline Fuel cost (BEB in \$/kWh, CNG in $\left.\$ / g^{\prime} e^{c}\right)$ & 0.18 & 0.18 & 1.05 \\
\hline Fuel cost $(\$ /$ mile $)$ & 0.45 & 0.45 & 0.28 \\
\hline Miles between roadcalls (MBRC) - bus ${ }^{d}$ & 5,680 & 8,053 & 25,125 \\
\hline MBRC - propulsion system only ${ }^{d}$ & 13,425 & 17,001 & 37,860 \\
\hline MBRC - ESSe only ${ }^{d}$ & 196,898 & 153,005 & - \\
\hline Total maintenance cost $(\$ / \text { mile })^{f}$ & 0.500 & 0.564 & 0.320 \\
\hline Maintenance cost - propulsion system only (\$/mile) & 0.182 & 0.225 & 0.133 \\
\hline \multicolumn{4}{|c|}{ 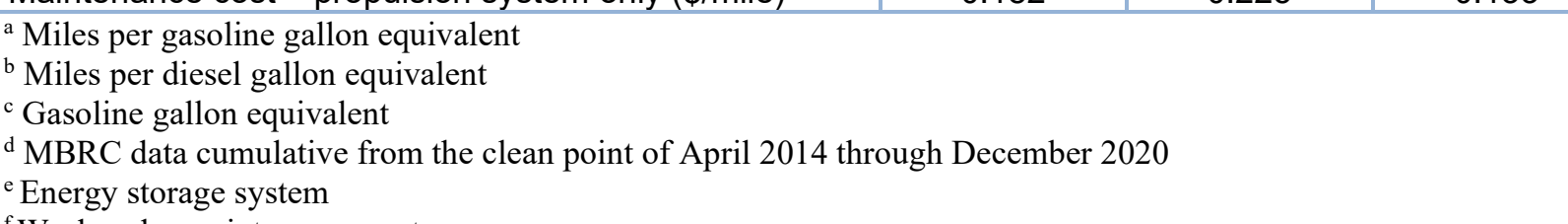 } \\
\hline
\end{tabular}

The average availability for the BEBs was $80.6 \%$ for the BEB $35 \mathrm{FC}$ fleet and $76.1 \%$ for the BEB 40FC fleet, compared to $94 \%$ for the CNG baseline buses. The per-bus availability for the BEBs ranged from a low of $67 \%$ to a high of $88 \%$. The BEB 35FC fleet had consistently high availability during the first few years of the evaluation and began to decline steadily from 2017 through 2020. Most of the issues causing downtime were general bus issues not related to the propulsion system. Electric drive system issues were the second most common reason for downtime, followed by transmission issues. For the BEB 40FC fleet, the most common reason for downtime was general bus issues, followed by charging system issues. For the CNG buses, most downtime was caused by general bus issues, followed by engine issues.

The BEB fleets had overall average efficiencies of $2.15 \mathrm{kWh}$ per mile for BEB 35FC and 2.10 $\mathrm{kWh}$ per mile for BEB 40FC, which equate to diesel-equivalent fuel economies of $17.47 \mathrm{mpdge}$ and 17.96 mpdge, respectively. The CNG fleet had an average diesel-equivalent fuel economy of 4.29 mpdge, approximately four times lower than that of the BEB fleets. The operating duty cycle of a bus has a significant effect on fuel economy. Because Foothill Transit operates its 
BEB and CNG bus fleets differently, the efficiency results presented here are not compared on the same duty cycle.

Foothill Transit has been subject to multiple electricity rate structures over the last 6 years. On average, the agency paid $\$ 0.18$ per $\mathrm{kWh}$ to charge the BEBs. The cost for $\mathrm{CNG}$ at Pomona averaged \$1.21 per diesel gallon equivalent (dge) during the same period. Based on the total electricity Foothill Transit purchased from the utility to charge the BEBs, the energy cost was $\$ 0.45$ per mile. The $\mathrm{CNG}$ fleet averaged $\$ 0.28$ per mile for fuel.

NREL tracks the bus reliability - measured as miles between roadcalls (MBRC). The overall bus MBRC for the BEB fleet through December 2020 was 5,680 for the BEB 35FC fleet and 8,053 for the BEB 40FC fleet. This is higher than the target of 4,000 $\mathrm{MBRC}^{1}$ but much lower than that of the CNG buses, which achieved more than 25,000 MBRC. The propulsion system-related MBRC was 13,425 for the BEB 35FC fleet and 17,001 for the BEB $40 \mathrm{FC}$ fleet, compared to 37,860 for the CNG buses.

NREL also analyzed work order data to provide a comparison of maintenance costs between the BEBs and the baseline CNG fleet. After removing accident- and warranty-related items for both fleets, the average per-mile maintenance cost was $\$ 0.50 / \mathrm{mi}$ for the BEB $35 \mathrm{FC}$ fleet, $\$ 0.56 / \mathrm{mi}$ for the BEB 40FC fleet, and $\$ 0.32 / \mathrm{mi}$ for the CNG fleet. These combined totals include scheduled and unscheduled maintenance. Costs for all three fleets have increased over time as the buses age; however, the increasing cost trend for the BEBs was steeper than that of the CNG buses. The propulsion-related maintenance costs for the BEB 35FC buses were $37 \%$ greater than that of the $\mathrm{CNG}$ buses. For the BEB 40FC buses, the propulsion-related costs were $70 \%$ greater than that of the CNG fleet.

After 6 years, the BEB 35FC fleet has reached half its expected life and is showing signs of wear. Foothill Transit has experienced several issues with the Pomona BEBs that caused downtime and resulted in higher maintenance costs, including the premature failure of lowvoltage batteries, issues with bolts on the rooftop charging system, tire wear, parts availability, and parts cost.

\section{Arcadia Results Summary}

NREL collects data on three fleets operated out of the Arcadia facility: 14 40-ft E2s (BEB 40E2), 14 40-ft CNG buses, and three 35-ft E2s (BEB 35E2). Although Foothill Transit's BEB 35E2 fleet is not a focus of this report, NREL collects mileage and energy data for these buses to calculate cost per mile for Arcadia because all 17 BEBs are charged at the facility. Table ES-2 provides a summary of selected data on the three fleets. Since being placed into service, the BEB 40E2 fleet has traveled more than 507,000 miles with an average monthly mileage per bus of 3,022 miles. The CNG buses accumulated 4,687 miles per month, on average. The BEBs are operated primarily on Line 280 and the CNG buses are randomly dispatched on all routes out of the Arcadia Operations and Maintenance facility. The BEB 40E2 fleet at Arcadia had some

\footnotetext{
1 "Fuel Cell Bus Targets," Fuel Cell Technologies Program Record \# 12012, Sept. 2012, www.hydrogen.energy.gov/pdfs/12012_fuel_cell_bus_targets.pdf.
} 
slowdown of use in April and May 2020 due to the COVID-19 pandemic, but not to the same degree as the Pomona BEBs.

The average availability for the BEB 40E2 fleet was $82 \%$, compared to $94 \%$ for the CNG baseline buses. The per-bus availability for the BEBs ranged from a low of $43 \%$ to a high of $95 \%$. Most of the downtime for the BEBs was related to general bus issues. The BEB fleet also experienced downtime due to transmission issues and a few problems with electric drive systems in the second half of the evaluation period. The primary reasons for CNG fleet downtime were divided between general bus-related maintenance and engine issues.

Table ES-2. Summary of Evaluation Results, Arcadia

\begin{tabular}{|c|c|c|c|}
\hline Data Item & BEB 40E2 & BEB 35E2 & CNG \\
\hline Number of buses & 14 & 3 & 14 \\
\hline Model year & 2017 & 2019 & 2017 \\
\hline Data period & $\begin{array}{l}1 / 2020 \\
12 / 2020\end{array}$ & $\begin{array}{l}1 / 2020 \\
12 / 2020\end{array}$ & $\begin{array}{l}1 / 2020 \\
12 / 2020\end{array}$ \\
\hline Number of months & 12 & 12 & 12 \\
\hline Total mileage in data period & 507,619 & 100,130 & 787,353 \\
\hline Average monthly mileage per bus & 3,022 & 2,781 & 4,687 \\
\hline Availability ( $85 \%$ is target) & 81.9 & - & 93.5 \\
\hline Average speed (mph) & 21.0 & 17.9 & 17 \\
\hline Fuel economy (BEB in kWh/mile or CNG in mpgge) & 1.90 & 1.82 & 3.38 \\
\hline Fuel economy (mpdge) & 19.76 & 20.71 & 3.88 \\
\hline Fuel cost (BEB in \$/kWh, CNG in \$/gge) & 0.19 & 0.19 & 1.27 \\
\hline Fuel cost (\$/mile) & 0.42 & 0.42 & 0.37 \\
\hline MBRC - bus ${ }^{a}$ & 23,074 & - & 24,605 \\
\hline MBRC - propulsion system only ${ }^{a}$ & 33,841 & - & 31,494 \\
\hline MBRC - ESS onlya & - & - & - \\
\hline Total maintenance cost $(\$ / \text { mile })^{b}$ & 0.364 & - & 0.354 \\
\hline Maintenance cost - propulsion system only ( $\$ /$ mile) & 0.101 & - & 0.120 \\
\hline
\end{tabular}

${ }^{a}$ MBRC data cumulative from the clean point of April 2014 through December 2016

${ }^{\mathrm{b}}$ Work order maintenance cost.

The BEB 40E2 fleet had an overall average efficiency of $1.9 \mathrm{kWh}$ per mile, which equates to a diesel-equivalent fuel economy of 19.76 mpdge. The CNG fleet had an average diesel-equivalent fuel economy of 3.88 mpdge, approximately four times lower than that of the BEB fleet. The BEB 40E2 fleet is primarily charged by plugging into depot chargers overnight but can take advantage of the overhead fast charger at the Azusa Intermodal Transit Center (AITC). The overall average electricity price for the BEB fleet was $\$ 0.19$ per $\mathrm{kWh}$. This equates to an energy cost of $\$ 0.42 / \mathrm{mi}$ for the BEB 40E2 fleet. At an average price of $\$ 1.46 / \mathrm{dge}$, the fuel cost for the CNG buses was $\$ 0.37 /$ mile.

The overall bus MBRC for the BEB 40E2 fleet was 23,074, which is similar to that of the CNG buses at 24,605 MBRC. The propulsion system-related MBRC was 33,841 for the BEB 40E2 fleet, compared to 31,494 for the CNG buses.

Both the BEB and CNG fleets at Arcadia are under warranty, resulting in low maintenance costs. The average per-mile maintenance cost for the BEB 40E2 fleet was $\$ 0.36 / \mathrm{mi}$ and $\$ 0.35 / \mathrm{mi}$ for 
the CNG buses. The propulsion-related maintenance costs for the BEB 40E2 fleet was 16\% lower than that of the CNG buses.

\section{Summary of Experience}

Foothill Transit was an early adopter of BEB technology, deploying one of the first fleets of BEBs in larger numbers than previous demonstrations. This early demonstration was valuable to help the original equipment manufacturer (OEM) identify issues, develop solutions, and make design improvements for the next-generation buses. However, early adopter agencies take on added risk and cost during these demonstrations.

Advanced technology demonstrations typically experience new and sometimes unique challenges that need to be resolved to continue advancing the state of the technology. This section summarizes the primary challenges experienced by Foothill Transit during the evaluation.

BEB range - Foothill Transit reports that it still has range limitations because the current extended-range BEB technology cannot meet all its service blocks. Some planned blocks include interlines between multiple routes, which are too long for the BEBs. The agency is exploring options for meeting these more demanding routes with zero-emission buses (ZEBs) in the future.

On-route chargers - Deploying on-route chargers can be complicated and expensive. An agency needs to find the optimal site for charger installation and may need more than one site to cover multiple routes.

On-route charger availability - For on-route charged buses, availability of the charger is paramount for operating BEBs. Foothill Transit installed two chargers at its Pomona Transit Center to help avoid schedule delays and downtime of the fast-charge BEBs. In May 2020, one of the chargers experienced a thermal event in which electrical arcing at the charging interface ignited a fire during a charging event, damaging the charger and taking it out of service. When a similar event in October 2020 damaged the remining charger, the agency was forced to park the fast-charge BEB fleet and service the route with CNG buses until the chargers could be repaired. The extensive downtime for the chargers highlights the critical role of charger availability in successfully operating BEBs.

Coordination with charger installation and bus delivery-One of the biggest challenges Foothill Transit experienced with deploying its BEB 40E2 fleet was planning and installation of the charging infrastructure at the Arcadia facility. Delays in planning and construction resulted in the buses being delivered before Foothill Transit had the means to consistently charge the entire BEB fleet. Although bus delivery began in 2017, the agency was not able to put the buses in full service until early 2020, after the charging infrastructure had been completed and commissioned.

Foothill Transit has gained valuable experience in deploying BEBs. The agency highlights the following key recommendations for other agencies when considering deployment of BEBs:

- Conduct a full analysis of your routes to identify the energy requirements to meet service. Use the data collected to model the number of BEBs that would be required. Some routes will be well suited for the current capabilities of electric buses and others might require 
midday charging or more buses. Understand that heating, ventilation, and airconditioning (HVAC) use lowers the effective range in warmer and cooler months and take this into account when planning service. Also consider battery degradation over time to determine if a particular BEB can meet service as it ages.

- Design and develop the infrastructure based on the route analysis to ensure you can charge the buses effectively.

- Work with the local utility to install charging infrastructure and address potential costs for demand and time-of-use charges. Start discussions with the utility early in the planning process.

- Consider redundant chargers for on-route charged buses to avoid downtime.

- Plan for cost and operational impacts when adding new technology buses. Agencies need to train staff, including operators, maintenance technicians, and dispatchers. Develop procedures to ensure BEBs are fully charged in time for service.

- Develop a plan for how to handle meeting service with BEBs during an emergency. Traffic backups can result in depletion of charge before the buses complete routes. Consider how to charge buses during major power outages.

- Monitor BEB performance to help identify potential issues prior to failure and understand how the buses are operating in your service. There are different options to collect and analyze bus performance data. Many OEMs provide solutions for tracking performance. Another option is outfitting buses with data loggers from third-party companies that can collect data on any bus OEM.

With the arrival of 2 Alexander Dennis double deck electric buses in January 2021, Foothill Transit's fleet of BEBs has grown to 34 buses. The agency continues to work to fully transition its fleet to zero-emission buses and meet state regulations. The agency is exploring options for ZEB technologies to meet the requirements for some of its longer routes which surpass 150miles. Evaluations of fuel cell electric buses (FCEBs) have shown range and operational characteristics similar to CNG buses. Foothill Transit is moving forward with an order of 20 FCEBs and a hydrogen station slated for completion in the third quarter of 2022. Results from these deployments will allow a comparison between the two ZEB technologies and provide data the agency will use in future purchase decisions. 


\section{Table of Contents}

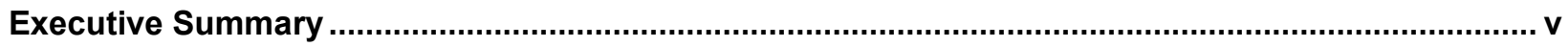

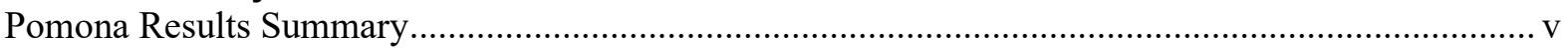

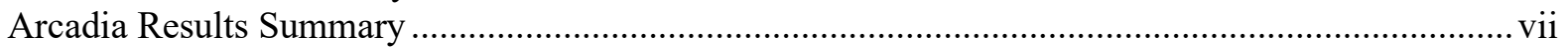

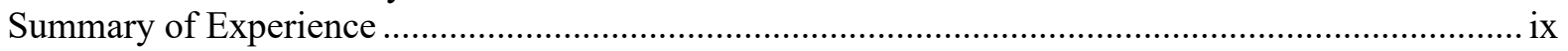

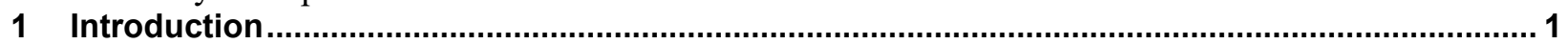

1.1 Fleet Profile_-Foothill Transit Agency.................................................................................. 1

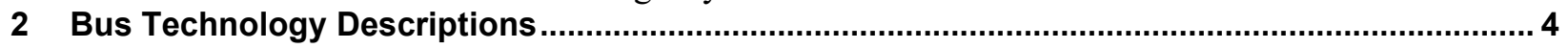

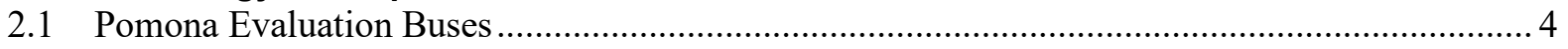

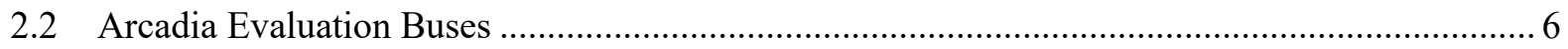

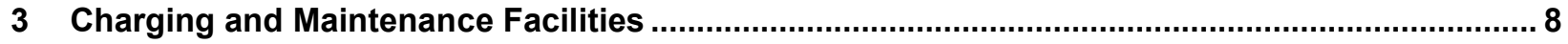

3.1 Pomona Operations and Maintenance Facility .................................................................... 8

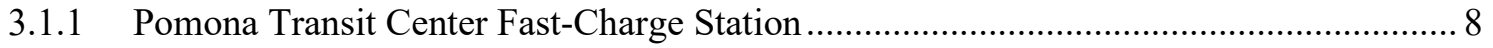

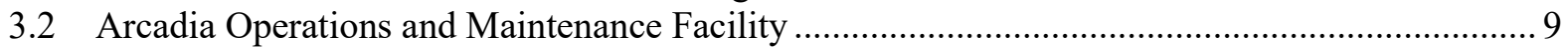

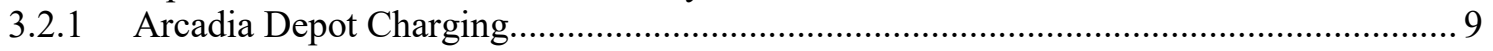

3.2.2 Azusa Intermodal Transit Center Fast-Charge Station............................................... 10

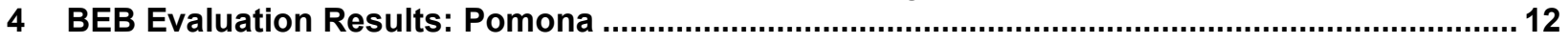

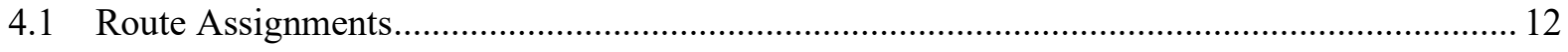

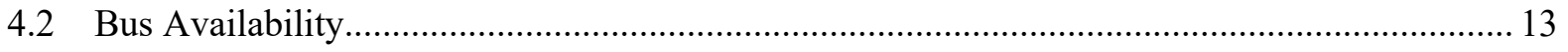

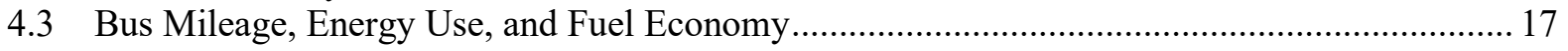

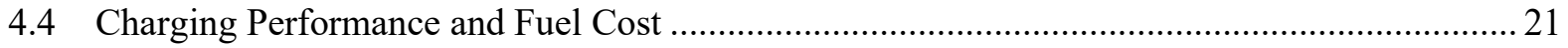

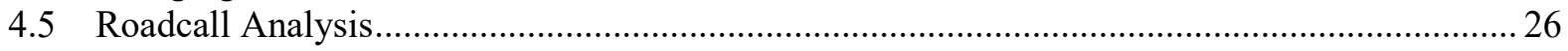

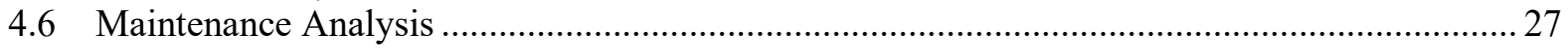

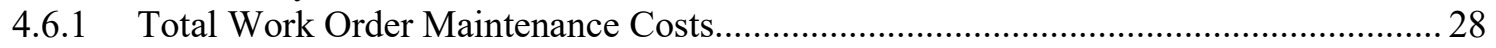

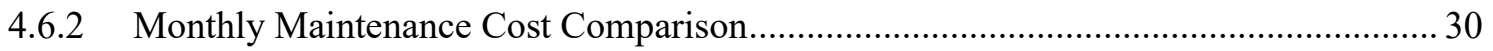

4.6.3 Work Order Maintenance Costs Categorized by System .......................................... 33

4.6.4 Propulsion-Related Work Order Maintenance Costs ................................................ 35

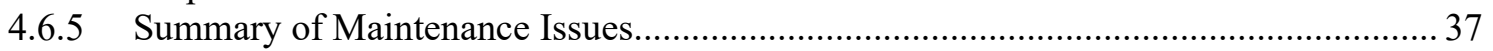

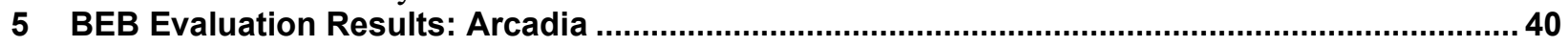

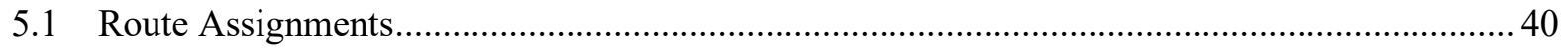

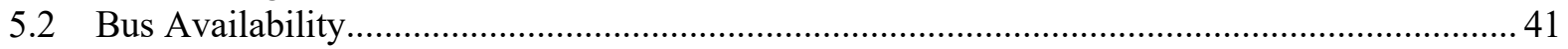

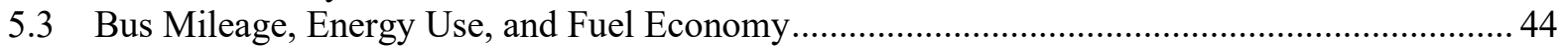

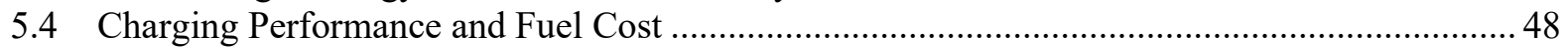

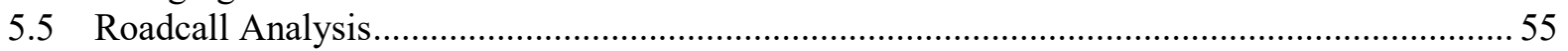

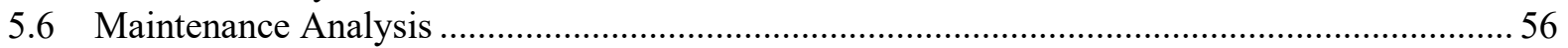

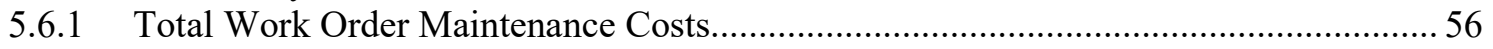

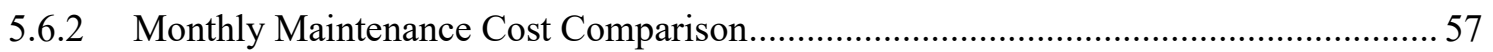

5.6.3 Work Order Maintenance Costs Categorized by System ............................................... 60

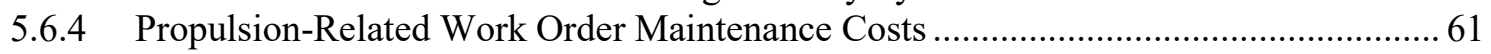

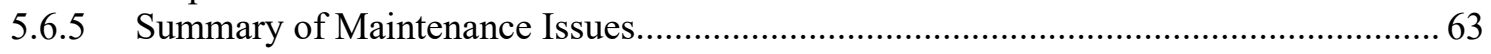

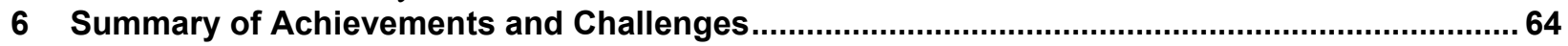

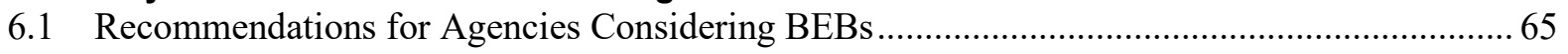

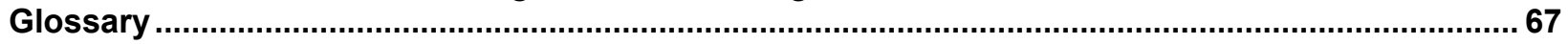

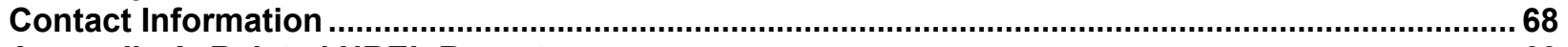

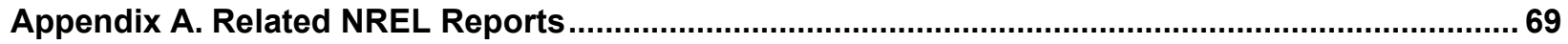

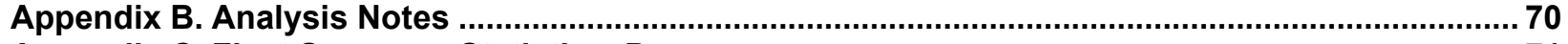

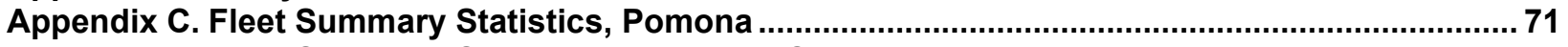

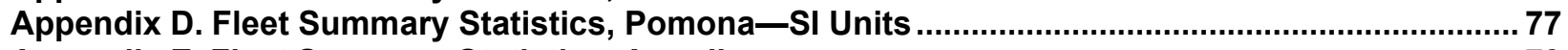

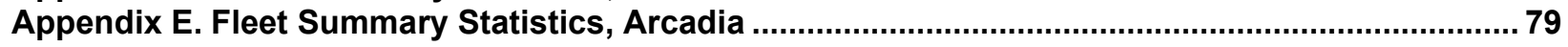

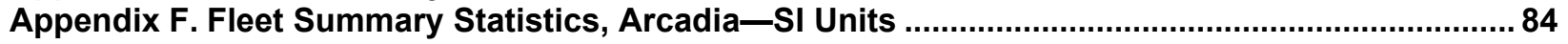




\section{List of Figures}

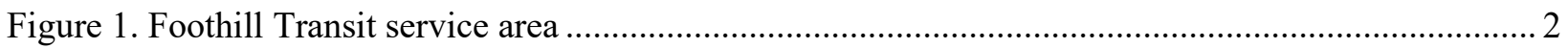

Figure 2. Foothill Transit Proterra BE 35 electric bus (BEB 35FC fleet) .............................................. 5

Figure 3. Foothill Transit Proterra Catalyst electric bus (BEB 40FC fleet) ............................................... 5

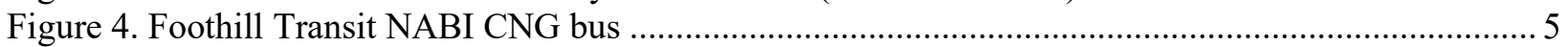

Figure 5. Foothill Transit Proterra Catalyst E2 electric bus (BEB 40E2 fleet)....................................... 6

Figure 6. Foothill Transit Proterra Catalyst E2 electric bus (BEB 35E2 fleet)....................................... 7

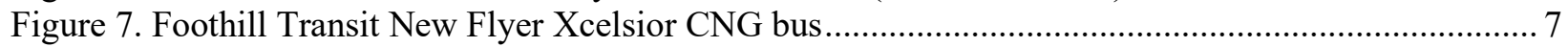

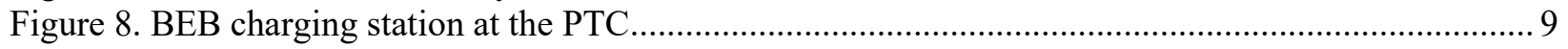

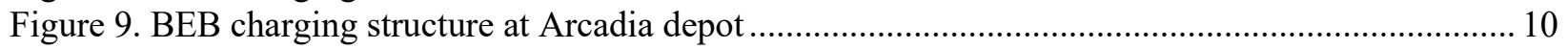

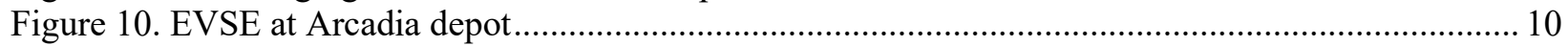

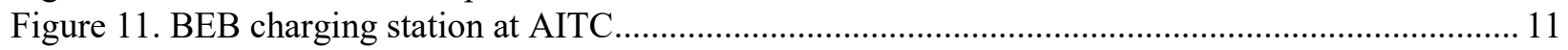

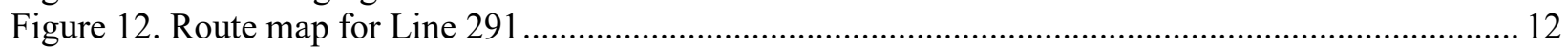

Figure 13. Routes traveled by randomly-dispatched CNG buses (red) and Line 291 traveled by the BEBs

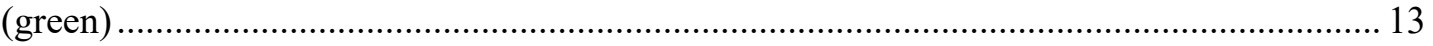

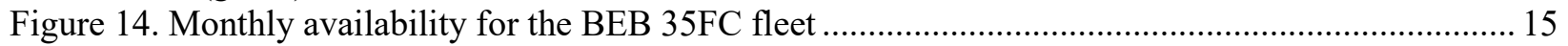

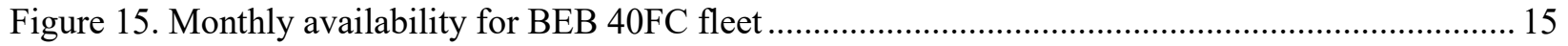

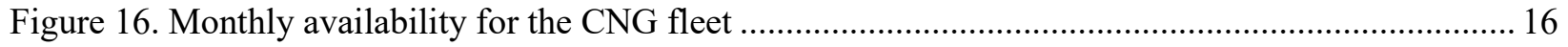

Figure 17. Cumulative availability for the Pomona BEB and CNG fleets ............................................ 17

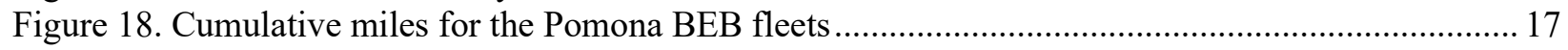

Figure 19. Average monthly miles for the Pomona BEB and CNG fleets............................................. 19

Figure 20. Monthly average fuel economy for the BEB and CNG fleets ............................................ 21

Figure 21. Impact of ambient temperature on median fuel economy ....................................................2 21

Figure 22. Number of daily charges and average charge duration for the Pomona BEBs........................ 22

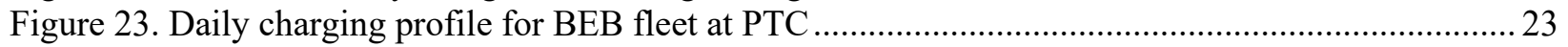

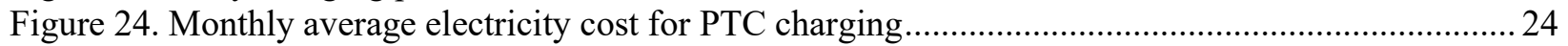

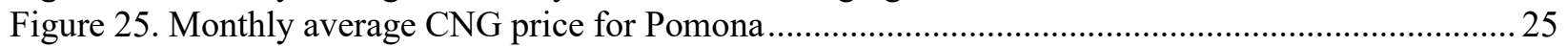

Figure 26. Monthly average fuel price for the BEB and CNG fleets..................................................25

Figure 27. Monthly average energy cost per mile for the BEB and CNG fleets ...................................26

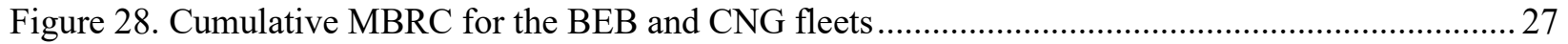

Figure 29. Cumulative maintenance costs per mile for the BEB and CNG fleets .................................29

Figure 30. Monthly maintenance costs per mile for the BEB and CNG fleets ..................................... 30

Figure 31. Monthly scheduled and unscheduled maintenance costs per mile for the BEB 35FC fleet ...... 31

Figure 32. Monthly scheduled and unscheduled maintenance costs per mile for the BEB 40FC fleet ...... 31

Figure 33. Monthly scheduled and unscheduled maintenance costs per mile for the CNG fleet ............... 31

Figure 34. Monthly parts and labor maintenance costs per mile for the BEB 35FC fleet ........................ 32

Figure 35. Monthly parts and labor maintenance costs per mile for the BEB 40FC fleet .......................... 32

Figure 36. Monthly parts and labor maintenance costs per mile for the CNG fleet ................................ 33

Figure 37. Monthly maintenance cost per mile by vehicle system for the BEB 35FC fleet....................... 34

Figure 38. Monthly maintenance cost per mile by vehicle system for the BEB 40FC fleet..................... 35

Figure 39. Monthly maintenance cost per mile by vehicle system for the CNG fleet............................... 35

Figure 40. Monthly maintenance cost per mile by propulsion subsystem for the BEB 35FC fleet............ 36

Figure 41. Monthly maintenance cost per mile by propulsion subsystem for the BEB 40FC fleet............ 37

Figure 42. Monthly maintenance cost per mile by propulsion subsystem for the CNG fleet .................... 37

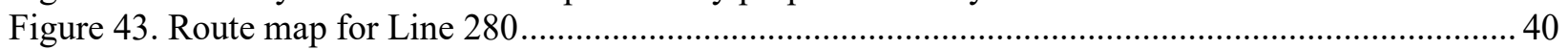

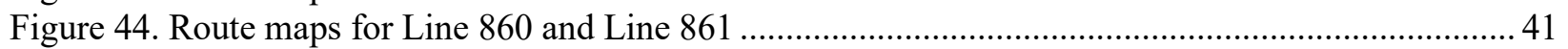

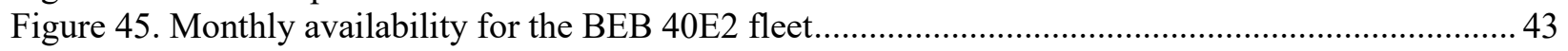

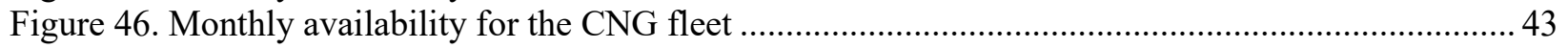

Figure 47. Cumulative availability for the BEB 40E2 and CNG fleets ............................................... 44 
Figure 48. Cumulative miles for the Arcadia BEB fleets

Figure 49. Average monthly miles for the Arcadia BEB and CNG fleets ......................................... 46

Figure 50. Monthly average fuel economy for the BEB and CNG fleets ............................................... 48

Figure 51. Energy regen and energy consumption by subsystem, BEB 40E2 fleet.................................. 48

Figure 52. Charge energy and charge duration for the BEBs at Arcadia ............................................... 49

Figure 53. ESS SOC by charging method and BEB daily distance for the BEBs at Arcadia.................... 49

Figure 54. Daily total charging profile for BEB fleet at Arcadia depot................................................. 50

Figure 55. Heatmap of energy consumption by TOU category for Arcadia depot charging ..................... 51

Figure 56. Average TOU electricity consumption rates for Arcadia depot charging .............................. 51

Figure 57. Monthly electricity costs for Arcadia depot charging ..........................................................5 52

Figure 58. Monthly electricity costs for AITC fast charging ............................................................ 52

Figure 59. Monthly electricity consumption for Arcadia depot and AITC charging ................................5 53

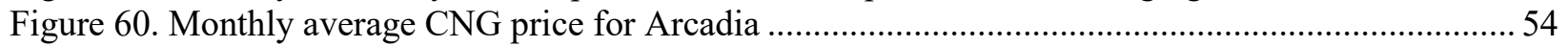

Figure 61. Monthly average fuel price for the BEBs and CNG fleets ................................................... 54

Figure 62. Monthly average fuel cost per mile for the BEB and CNG fleets ....................................... 55

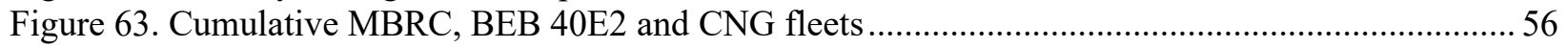

Figure 64. Monthly maintenance costs per mile, BEB 40E2 and CNG fleets ….................................5 58

Figure 65. Monthly scheduled and unscheduled maintenance costs per mile, BEB 40E2 fleet .................58

Figure 66. Monthly scheduled and unscheduled maintenance costs per mile, CNG fleet ........................59

Figure 67. Monthly parts and labor maintenance costs per mile, BEB 40E2 fleet .................................59

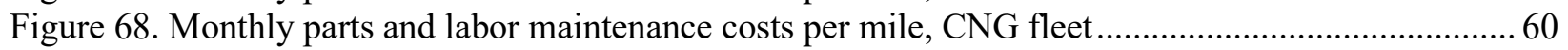

Figure 69. Monthly maintenance cost per mile by vehicle system, BEB 40E2 fleet............................... 61

Figure 70. Monthly maintenance cost per mile by vehicle system, CNG fleet...................................... 61

Figure 71. Monthly maintenance cost per mile by propulsion subsystem, BEB 40E2 fleet..................... 62

Figure 72. Monthly maintenance cost per mile by propulsion subsystem, CNG fleet ............................. 63 


\section{List of Tables}

Table ES-1. Summary of Evaluation Results, Pomona (Fast-Charge BEBs) ..........................................vi

Table ES-2. Summary of Evaluation Results, Arcadia ........................................................................ viii

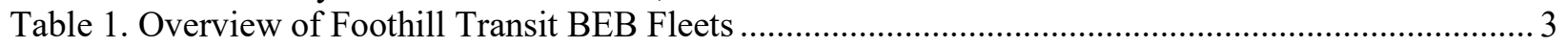

Table 2. Pomona Facility BEB and CNG Bus Specifications ............................................................. 4

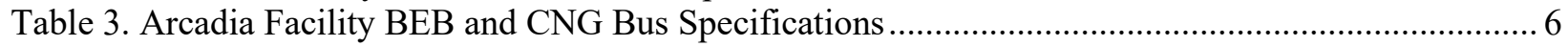

Table 4. Summary of Availability by Bus for the Pomona BEB Fleets .................................................. 14

Table 5. Summary of Availability and Unavailable Days for the Pomona BEB and CNG Fleets ............. 16

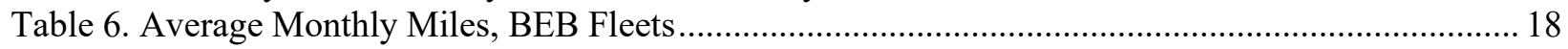

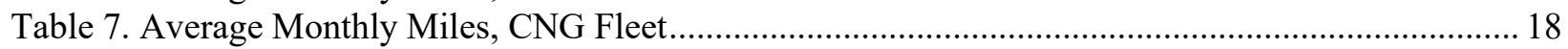

Table 8. Energy Use and Fuel Economy for the BEB Fleets.............................................................. 20

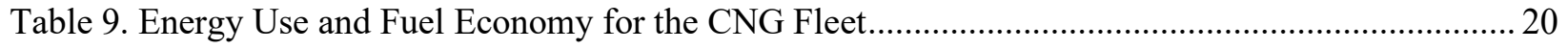

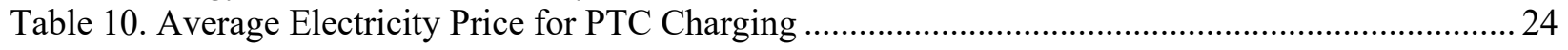

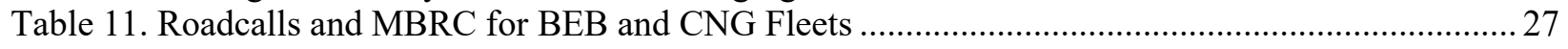

Table 12. Total Work Order Maintenance Costs, BEB Fleets ................................................................28

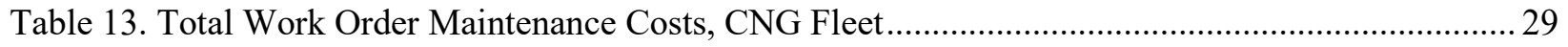

Table 14. Maintenance Cost per Mile by Vehicle System.................................................................... 34

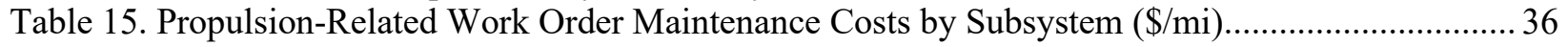

Table 16. Summary of Availability by Bus for the Arcadia BEB 40E2 Fleet .......................................... 42

Table 17. Summary of Availability by Bus for the Arcadia CNG Fleet ................................................ 42

Table 18. Summary of Availability and Unavailable Days for the BEB 40E2 and CNG Fleets ................ 43

Table 19. Average Monthly Miles, BEB 40E2 Fleet ......................................................................... 45

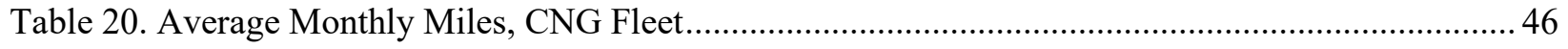

Table 21. Total Miles, Fuel Consumption, and Fuel Economy, BEB 40E2 Fleet .....................................47

Table 22. Total Miles, Fuel Consumption, and Fuel Economy, CNG Fleet............................................ 47

Table 23. Average Electricity Price for the Arcadia BEB Fleets..........................................................5

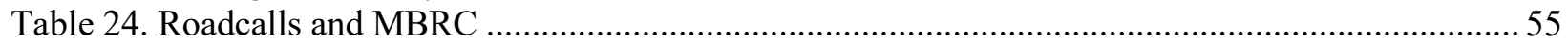

Table 25. Total Work Order Maintenance Costs, BEB 40E2 Fleet ................................................... 57

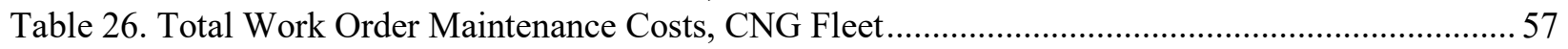

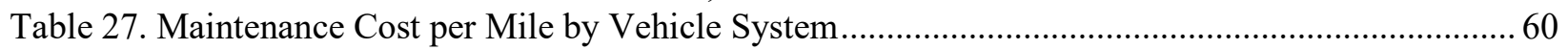

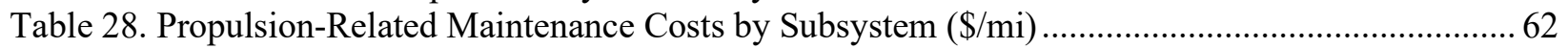




\section{Introduction}

This report summarizes the results of a battery electric bus (BEB) evaluation at Foothill Transit, located in Southern California. In 2010, Foothill Transit initiated a pilot project to evaluate the technology and determine the feasibility of BEBs for its service. Since that pilot project, the agency has added $31 \mathrm{BEBs}$ to its fleet. Foothill Transit is collaborating with the California Air Resources Board (CARB) and the U.S. Department of Energy's (DOE's) National Renewable Energy Laboratory (NREL) to evaluate the buses in revenue service. The focus of the evaluation is to compare performance and cost of the BEBs to that of conventional technology in similar service and track progress over time.

NREL has evaluated advanced technology transit buses for more than a decade. Recent evaluations focus on zero-emission buses (ZEBs) - both BEBs and fuel cell electric buses (FCEBs). The results of these evaluations are published with several objectives: document the performance results and lessons learned, present data and experience to aid interested agencies in deployments of ZEBs, and provide feedback to federal and state agencies that could inform research and development funding decisions.

NREL published the first report on the Foothill Transit BEBs in January 2016; that report covered the operation of the first BEB fleet during the initial data period of April 2014 to July 2015. A second technical report was published in 2017, followed by six semiannual progress reports, incorporating additional BEBs as they were deployed in service. A list of all previous NREL reports for the Foothill Transit evaluation is provided in Appendix A. This report summarizes the evaluation of four BEB fleets at two operating facilities, covering data analysis through December 2020. Data were provided by Foothill Transit on a selection of compressed natural gas $(\mathrm{CNG})$ buses for baseline fleet comparisons.

Each NREL evaluation tracks data and performance results for a specific transit agency operating a specific manufacturer's technology design. Results from different original equipment manufacturer (OEM) designs will vary and are not necessarily representative of a specific technology. Results will also vary from agency to agency and even between operating facilities within the same agency. Readers should keep this in mind when using these results for decisionmaking.

\subsection{Fleet Profile-Foothill Transit Agency}

Foothill Transit serves a 327-square-mile area covering the San Gabriel and Pomona Valley region of Los Angeles County. Foothill Transit's administrative office is in West Covina, California. Foothill Transit is governed by a joint powers authority of 22 member-cities and the County of Los Angeles, with representation from the following areas: 


$\begin{array}{ccc}\text { Arcadia } & \text { Azusa } & \text { Baldwin Park } \\ \text { Bradbury } & \text { Claremont } & \text { Covina } \\ \text { Diamond Bar } & \text { Duarte } & \text { El Monte } \\ \text { Glendora } & \text { Industry } & \text { Irwindale } \\ \text { La Puente } & \text { La Verne } & \text { Monrovia } \\ \text { Pasadena } & \text { Pomona } & \text { San Dimas } \\ \text { South El Monte } & \text { Temple City } & \text { Walnut } \\ \text { West Covina } & \text { Los Angeles County } & \end{array}$

Foothill Transit operates 36 local and express routes including commuter runs to downtown Los Angeles, serviced with $343 \mathrm{CNG}$ buses and 33 BEBs. Figure 1 shows the Foothill Transit service area.

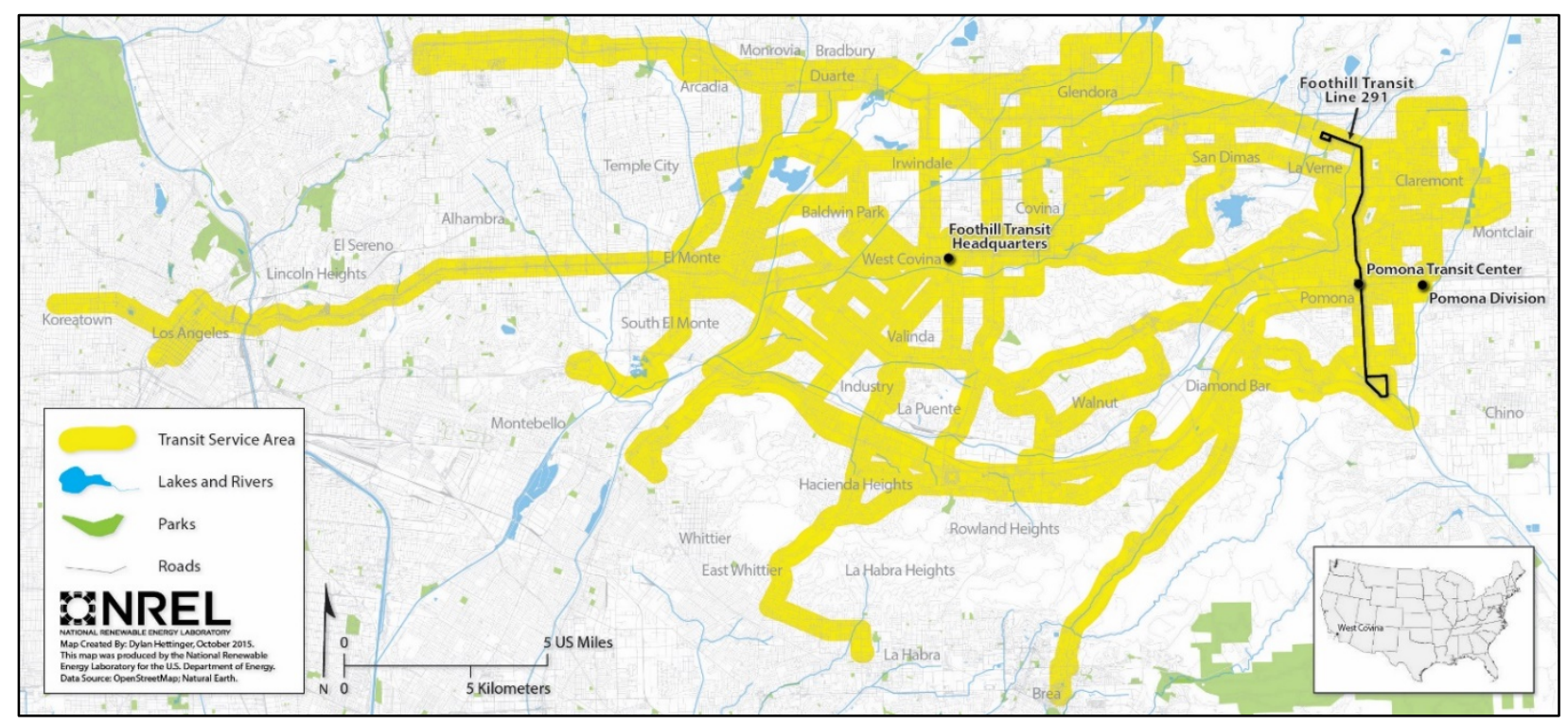

Figure 1. Foothill Transit service area

Foothill Transit operates BEBs at both its operation and maintenance facilities: Pomona and Arcadia. Table 1 outlines Foothill Transit's BEB fleets by facility. The Pomona facility has operated three fleets of BEBs, all of which are fast-charge buses. The Arcadia facility operates two BEB fleets that are primarily plugged in for overnight charging. The table includes a fleet ID code assigned by NREL to distinguish between fleets in the results section. NREL is collecting data on four of the five BEB fleets; the BEB pilot fleet is no longer in operation. The BEB 35E2 fleet at the Arcadia facility is not the focus of the report; however, NREL collects selected data to enable analysis of cost per mile for all the BEBs at the Arcadia facility. NREL collects electricity consumption data from the Arcadia utility bills but the charging data are not separated by bus; therefore, NREL must combine the mileage and charging data for both BEB fleets at Arcadia to calculate an average cost per mile. NREL collects data on a selection of CNG buses at each facility to provide a baseline comparison for the cost and performance of the BEB fleets. 
Table 1. Overview of Foothill Transit BEB Fleets

\begin{tabular}{|c|c|c|c|c|}
\hline Facility & BEB Fleet Description & Fleet ID & $\begin{array}{l}\text { Number of } \\
\text { Buses }\end{array}$ & Charging Strategy \\
\hline \multirow{3}{*}{ Pomona } & $\begin{array}{l}\text { Proterra BE35 } \\
35 \text {-ft fast charge }\end{array}$ & Pilot & 2 & On-route fast charging \\
\hline & $\begin{array}{l}\text { Proterra BE35 } \\
\text { 35-ft fast charge }\end{array}$ & BEB 35FC & 12 & On-route fast charging \\
\hline & $\begin{array}{l}\text { Proterra Catalyst } \\
40-\mathrm{ft} \text { fast charge }\end{array}$ & BEB 40FC & 2 & On-route fast charging \\
\hline \multirow[t]{2}{*}{ Arcadia } & $\begin{array}{l}\text { Proterra Catalyst E2 } \\
40-\mathrm{ft} \text { extended range }\end{array}$ & BEB 40E2 & 14 & $\begin{array}{l}\text { Plug-in depot charging and } \\
\text { supplemental on-route fast } \\
\text { charging }\end{array}$ \\
\hline & $\begin{array}{l}\text { Proterra Catalyst E2 } \\
35-\mathrm{ft} \text { extended range }\end{array}$ & BEB 35E2 & 3 & Plug-in depot charging \\
\hline
\end{tabular}

In early January 2020, Bus 2004 (of the BEB 35FC fleet) experienced a thermal event and was permanently removed from service. Foothill Transit determined the damage was severe and the bus was not salvageable. The agency reports that there is an ongoing investigation into the cause of the incident. NREL removed the bus from the analysis - data for 2020 include 11 buses for the BEB 35FC fleet.

The COVID-19 pandemic resulted in the need to reduce service during shutdowns. In March 2020, Foothill Transit reduced service to about $70 \%$ of normal operation. The agency increased service up to $95 \%$ in late June. During this period, the BEB 35FC and BEB 40FC fleets at Pomona were used sparingly and did not accumulate mileage at the same rate as before. Issues with the buses and downtime for the fast-charge station further reduced use of these buses through the end of 2020. This resulted in significantly lower mileage accumulation on the BEBs, which has a noticeable effect on analyses that use mileage for calculations. The level of service in 2020 is not representative of the fleet. For some charts, the low mileage results in extremely high values that extend out of range for the chart. NREL removed these data points from the charts; however, the data are included in the overall calculations. To show the effect of the 2020 data on the overall totals, Appendix C and Appendix D provide the overall totals for the Pomona buses and the totals for 2020 separately.

The BEB 40E2 fleet at Arcadia had some decreased use in April and May 2020 due to the pandemic, but not to the same degree as the Pomona BEBs. Overall, mileage accumulation for the BEB 40E2 fleet was consistent during the year at approximately 2,700 monthly miles per bus. As a result, analyses did not result in anomalous data points that required adjustments to the charts for the Arcadia buses. 


\section{Bus Technology Descriptions}

\subsection{Pomona Evaluation Buses}

The BEBs in service at Foothill Transit are composite-body buses built by Proterra. The BEBs at the Pomona facility are all fast-charge buses that use a high-powered overhead charger designed by Proterra. NREL collects data on conventional buses at each demonstration site for a baseline comparison to the BEB fleets. This is important because fuel economy and fuel costs are impacted by duty cycle and because operations and maintenance practices can vary from site to site, even within the same transit agency. To provide the best comparison to the BEBs and focus the evaluation on the difference in propulsion system, NREL selects the most similar baseline fleet available based on bus manufacturer, size/model, production year, and mileage/duty cycle. The CNG buses selected for baseline comparison to the BEBs are 40-ft North American Bus Industries (NABI) buses of the same model year as the BEB 35FC fleet, which was the first BEB fleet included in this evaluation. Table 2 provides bus specifications for the BEBs and baseline CNG buses at the Pomona facility. Figure 2, Figure 3, and Figure 4 show example photos of the Pomona 35-ft BEBs, 40-ft BEBs, and baseline CNG buses, respectively.

Table 2. Pomona Facility BEB and CNG Bus Specifications

\begin{tabular}{|c|c|c|c|}
\hline & BEB 35FC & BEB 40FC & CNG \\
\hline Number of buses & 12 & 2 & 8 \\
\hline $\begin{array}{l}\text { Bus manufacturer and } \\
\text { model }\end{array}$ & $\begin{array}{l}\text { Proterra } \\
\text { BE35 }\end{array}$ & $\begin{array}{c}\text { Proterra } \\
\text { Catalyst Fast Charge }\end{array}$ & $\begin{array}{c}\text { NABI } \\
\text { BRT-07.03 }\end{array}$ \\
\hline Model year & 2014 & 2016 & 2014 \\
\hline Bus purchase cost & $\$ 904,490$ & $\$ 879,845$ & $\$ 575,000$ \\
\hline Length/width/height & $35 \mathrm{ft} / 102 \mathrm{in} . / 129 \mathrm{in}$. & $42.5 \mathrm{ft} / 102 \mathrm{in} . / 134 \mathrm{in.}$ & $42 \mathrm{ft} / 102 \mathrm{in} . / 137 \mathrm{in}$. \\
\hline GVWRª/curb weight & $37,320 \mathrm{lb} / 27,680 \mathrm{lb}$ & $39,050 \mathrm{lb} / 27,000 \mathrm{lb}$ & $42,540 \mathrm{lb} / 33,880 \mathrm{lb}$ \\
\hline Wheelbase & $237 \mathrm{in}$ & 296 in. & 308 in. \\
\hline Passenger capacity & $\begin{array}{l}35 \text { seats, } 2 \text { wheelchair } \\
\text { positions, } 18 \text { standees }\end{array}$ & $\begin{array}{l}40 \text { seats, } 2 \text { wheelchair } \\
\text { positions, } 18 \text { standees }\end{array}$ & $\begin{array}{l}38 \text { seats, } 2 \text { wheelchair } \\
\text { positions, } 10 \text { standees }\end{array}$ \\
\hline Motor or engine & $\begin{array}{c}\text { Permanent magnet, UQM, } \\
\text { PP220 }\end{array}$ & $\begin{array}{l}\text { Permanent magnet, UQM, } \\
\text { PP220 }\end{array}$ & $\begin{array}{c}\text { CNG engine, Cummins, } \\
8.9 \mathrm{ISL} G\end{array}$ \\
\hline Rated power & 220-kW peak (295 hp) & 220-kW peak (295 hp) & $280 \mathrm{hp}$ at $2,200 \mathrm{rpm}$ \\
\hline $\begin{array}{l}\text { Energy storage (BEB) } \\
\text { Fuel capacity (CNG) }\end{array}$ & $\begin{array}{l}\text { Lithium-titanate batteries, } \\
\text { Altairnano, TerraVolt } 368 \\
\text { volts, } 88 \mathrm{kWh} \text { total energy }\end{array}$ & $\begin{array}{l}\text { Lithium-titanate batteries, } \\
\text { Toshiba, TerraVolt } 331 \\
\text { volts, } 106 \text { kWh total energy }\end{array}$ & $\begin{array}{l}7 \text { Type IV cylinders, } \\
22,204 \text { scf at } 3,600 \text { psi }\end{array}$ \\
\hline Accessories & Electric & Electric & Mechanical \\
\hline Emissions equipment & $\mathrm{N} / \mathrm{A}$ & $\mathrm{N} / \mathrm{A}$ & 3-way catalyst \\
\hline Transmission/retarder & Regenerative braking & Regenerative braking & $\mathrm{N} / \mathrm{A}$ \\
\hline
\end{tabular}

a Gross vehicle weight rating 


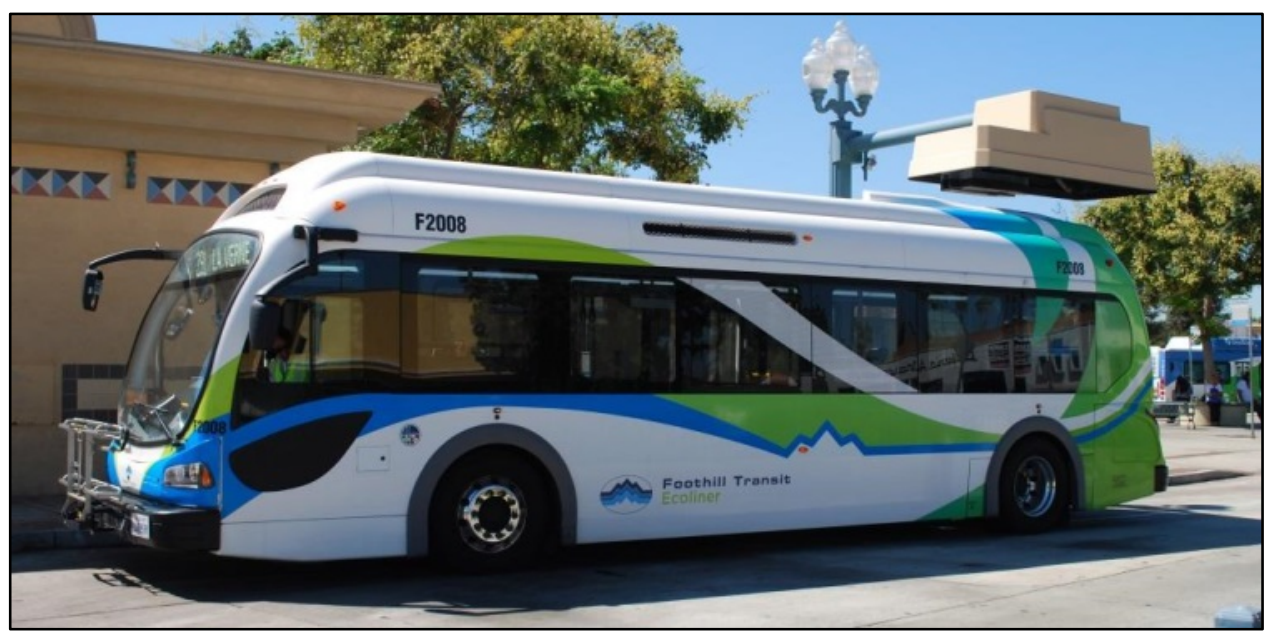

Figure 2. Foothill Transit Proterra BE 35 electric bus (BEB 35FC fleet)

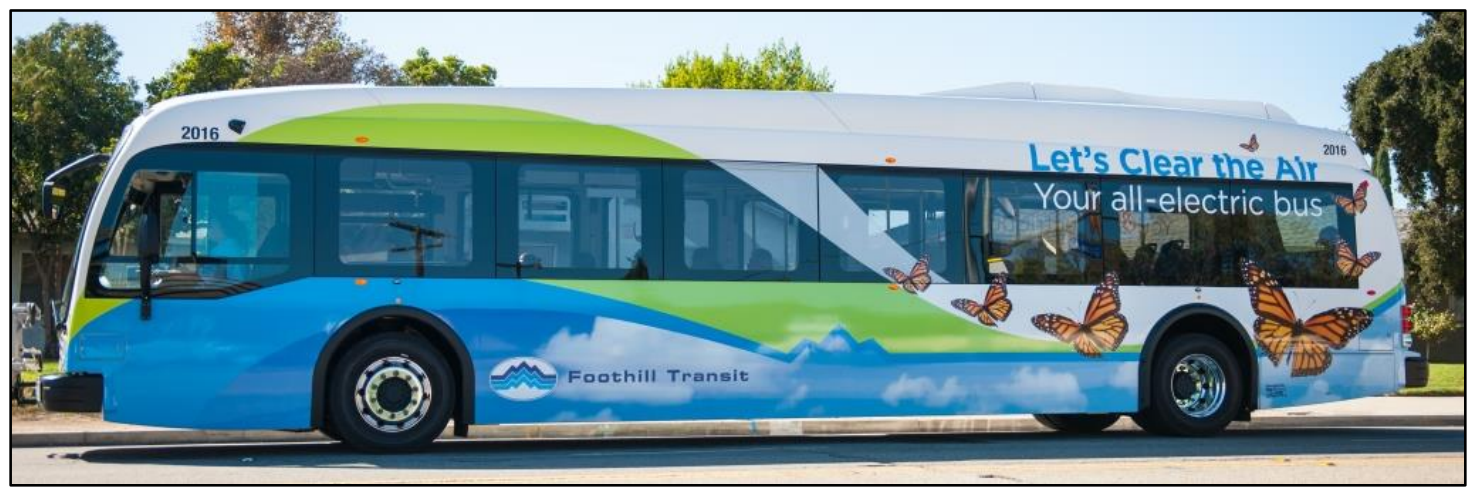

Figure 3. Foothill Transit Proterra Catalyst electric bus (BEB 40FC fleet)

Photo courtesy of Foothill Transit

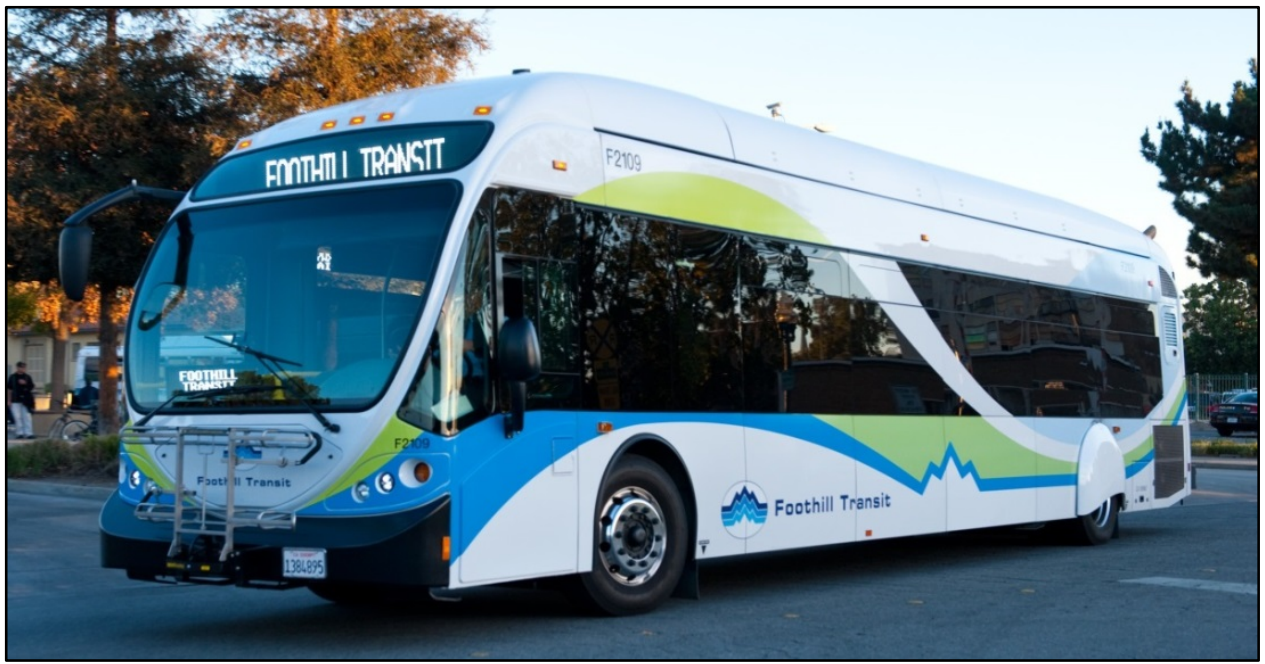

Figure 4. Foothill Transit NABI CNG bus 


\subsection{Arcadia Evaluation Buses}

The BEBs operating out of the Arcadia facility are extended-range buses built by Proterra. They are primarily charged by plugging in to electric vehicle supply equipment (EVSE) at the depot but are also capable of fast charging using the overhead charger like previous Proterra models. The baseline CNG fleet for Arcadia includes 14 New Flyer buses of the same model year as the BEB 40E2 fleet. Table 3 provides specifications for the BEBs and baseline CNG buses operated from the Arcadia facility. Figure 5, Figure 6, and Figure 7 show example photos for the Arcadia 40-ft BEBs, 35-ft BEBs, and baseline CNG buses, respectively.

Table 3. Arcadia Facility BEB and CNG Bus Specifications

\begin{tabular}{|c|c|c|}
\hline & BEB 40E2 & CNG \\
\hline Number of buses & 14 & 14 \\
\hline $\begin{array}{l}\text { Bus manufacturer and } \\
\text { model }\end{array}$ & $\begin{array}{l}\text { Proterra } \\
\text { Catalyst E2 }\end{array}$ & $\begin{array}{l}\text { New Flyer } \\
\text { Xcelsior XN40 }\end{array}$ \\
\hline Model year & 2017 & 2017 \\
\hline Bus purchase cost ${ }^{a}$ & $\$ 898,854$ & $\$ 575,000$ \\
\hline Length/width/height & $42 \mathrm{ft} / 102 \mathrm{in.} / 133 \mathrm{in.}$ & $40 \mathrm{ft} / 102 \mathrm{in.} / 133 \mathrm{in.}$ \\
\hline GVWR/curb weight & $42,000 \mathrm{lb} / 31,360 \mathrm{lb}$ & $43,720 \mathrm{lb} / 32,270 \mathrm{lb}$ \\
\hline Wheelbase & 296 in. & $283 \mathrm{in}$. \\
\hline Passenger capacity & 40 seats, 2 wheelchair positions & 35 seats, 2 wheelchair positions \\
\hline Motor or engine & Permanent magnet & CNG engine, Cummins, 8.9 ISL G \\
\hline Rated power & 220-kW peak & $280 \mathrm{hp}$ at $2,000 \mathrm{rpm}$ \\
\hline $\begin{array}{l}\text { Energy storage (BEB) } \\
\text { Fuel capacity (CNG) }\end{array}$ & $440 \mathrm{kWh}$ & $\begin{array}{c}7 \text { carbon fiber cylinders, Hexagon } \\
23,065 \text { scf at } 3,600 \text { psi }\end{array}$ \\
\hline Accessories & Electric & Mechanical \\
\hline Emissions equipment & $\mathrm{N} / \mathrm{A}$ & 3-way catalyst \\
\hline Transmission/retarder & Regenerative braking & $\mathrm{N} / \mathrm{A}$ \\
\hline
\end{tabular}

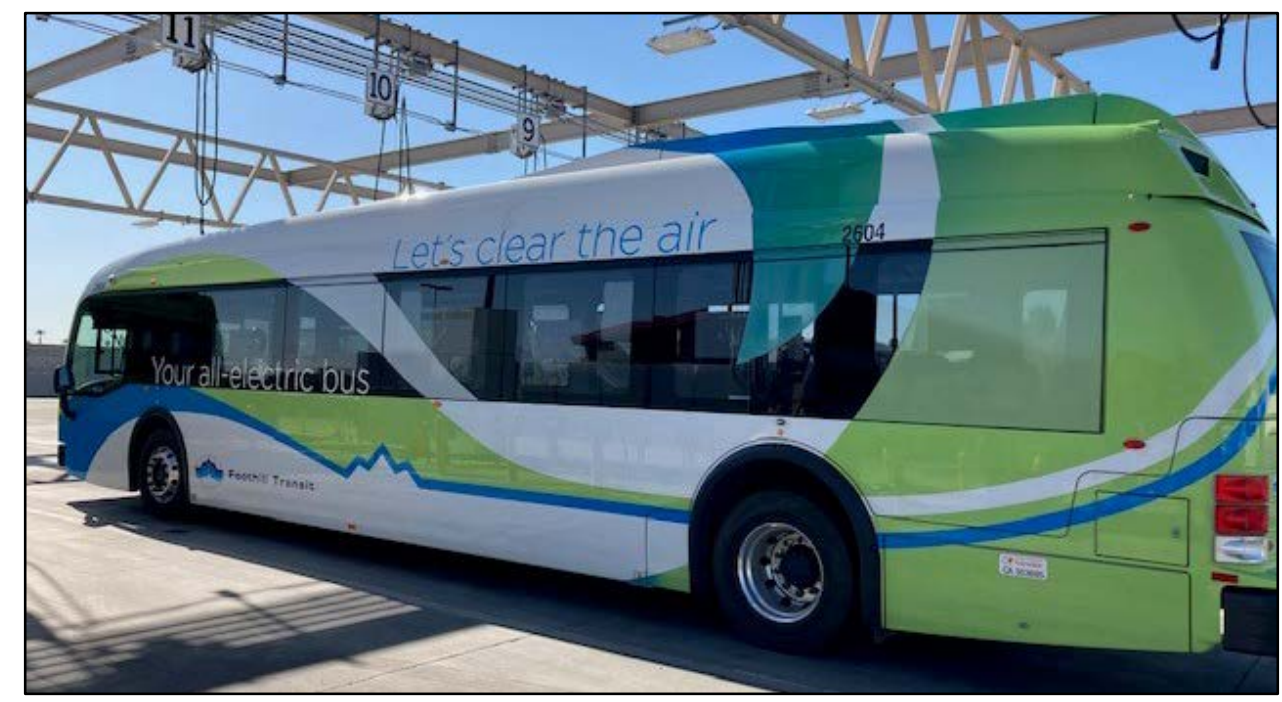

Figure 5. Foothill Transit Proterra Catalyst E2 electric bus (BEB 40E2 fleet)

Photo courtesy of Foothill Transit 


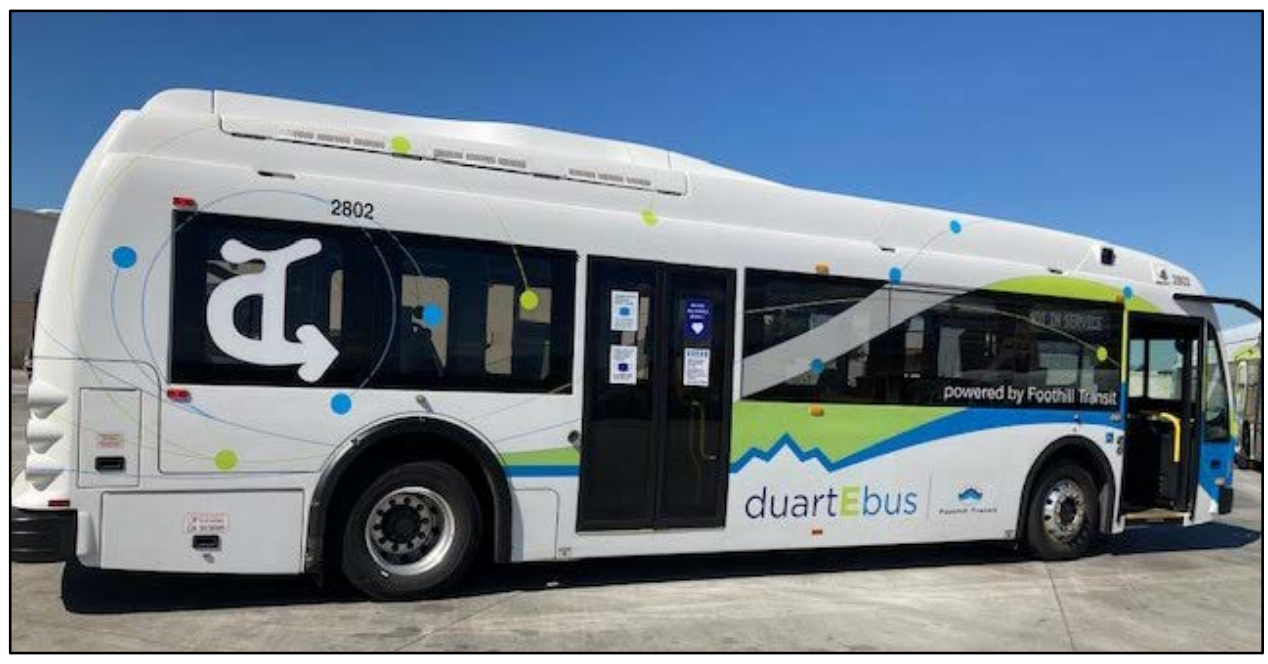

Figure 6. Foothill Transit Proterra Catalyst E2 electric bus (BEB 35E2 fleet)

Photo courtesy of Foothill Transit

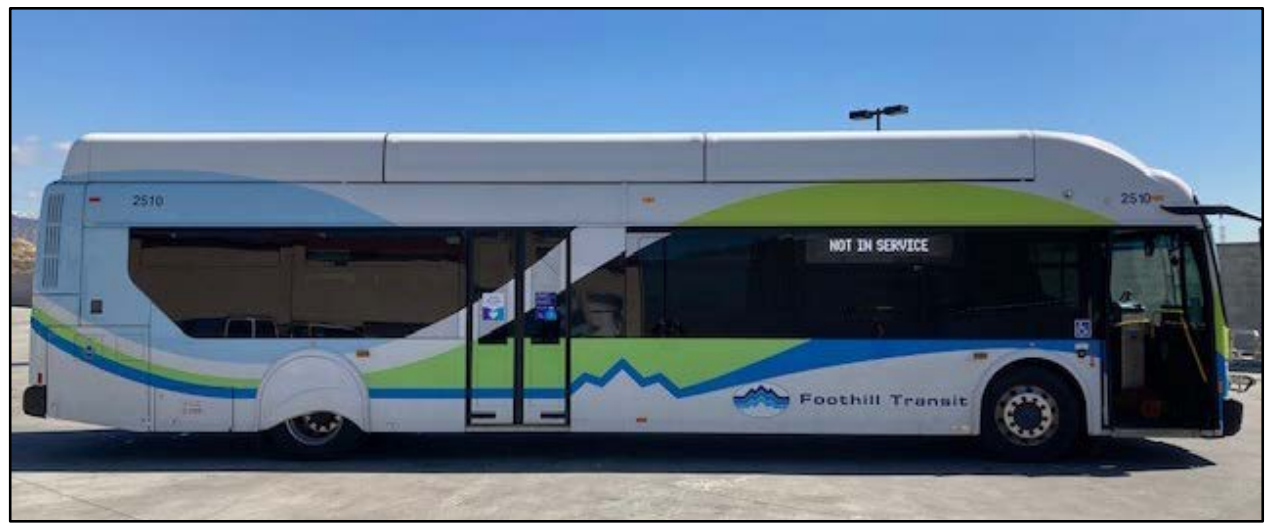

Figure 7. Foothill Transit New Flyer Xcelsior CNG bus

Photo courtesy of Foothill Transit 


\section{Charging and Maintenance Facilities}

Foothill Transit operates BEBs out of both the Pomona and Arcadia Operations and Maintenance facilities. Foothill Transit provides operation and maintenance of its fleets through contracts with private companies; the Pomona and Arcadia facilities are operated by different companies. This section outlines the modifications made at each facility to enable operation, charging, and maintenance of the BEBs.

\subsection{Pomona Operations and Maintenance Facility}

Foothill Transit introduced BEBs to its Pomona facility beginning with the pilot buses in 2010 . The BEB 35FC fleet was added in 2014 and the BEB 40FC fleet was added in 2016. These BEBs are now out of warranty for most bus systems. Maintenance staff at the Pomona facility handle all maintenance work on the CNG buses and cover most maintenance for the BEBs. Maintenance staff call on Proterra technicians as needed for troubleshooting and repair. A lowpower plug-in charger was installed at the operations and maintenance facility for times when a bus at the facility needs additional charging. The installation of this plug-in charger was the only modification needed to allow maintenance of the BEBs at Pomona. In recent years, Foothill Transit also installed a fast charger at the operations and maintenance facility at a cost of $\$ 665,000$ (charger and installation). The 500-kW charger is the same type as those used at the Pomona Transit Center (PTC), described below. At the end of each day, bus operators typically charge the BEBs at the PTC prior to returning to the depot. Otherwise, the fast charger at the operations and maintenance facility can be used to charge buses prior to service each day.

\subsubsection{Pomona Transit Center Fast-Charge Station}

Foothill Transit installed a fast-charge station at the PTC for on-route charging of the BEBs. The station consists of a climate-controlled building that holds two Eaton 500-kW chargers, each with one charge head located on opposite sides of the building. The two chargers operate as separate units with a dedicated control system for each. A common communication network serves both units with sensors to detect which charge head a bus is approaching to enable proper bus-to-charger communication for docking. Emergency shut-off switches for each charging head are located on both sides of the building. Figure 8 shows the fast-charge station with two BEBs at the charging heads. The building that houses the chargers and equipment is in the center. 


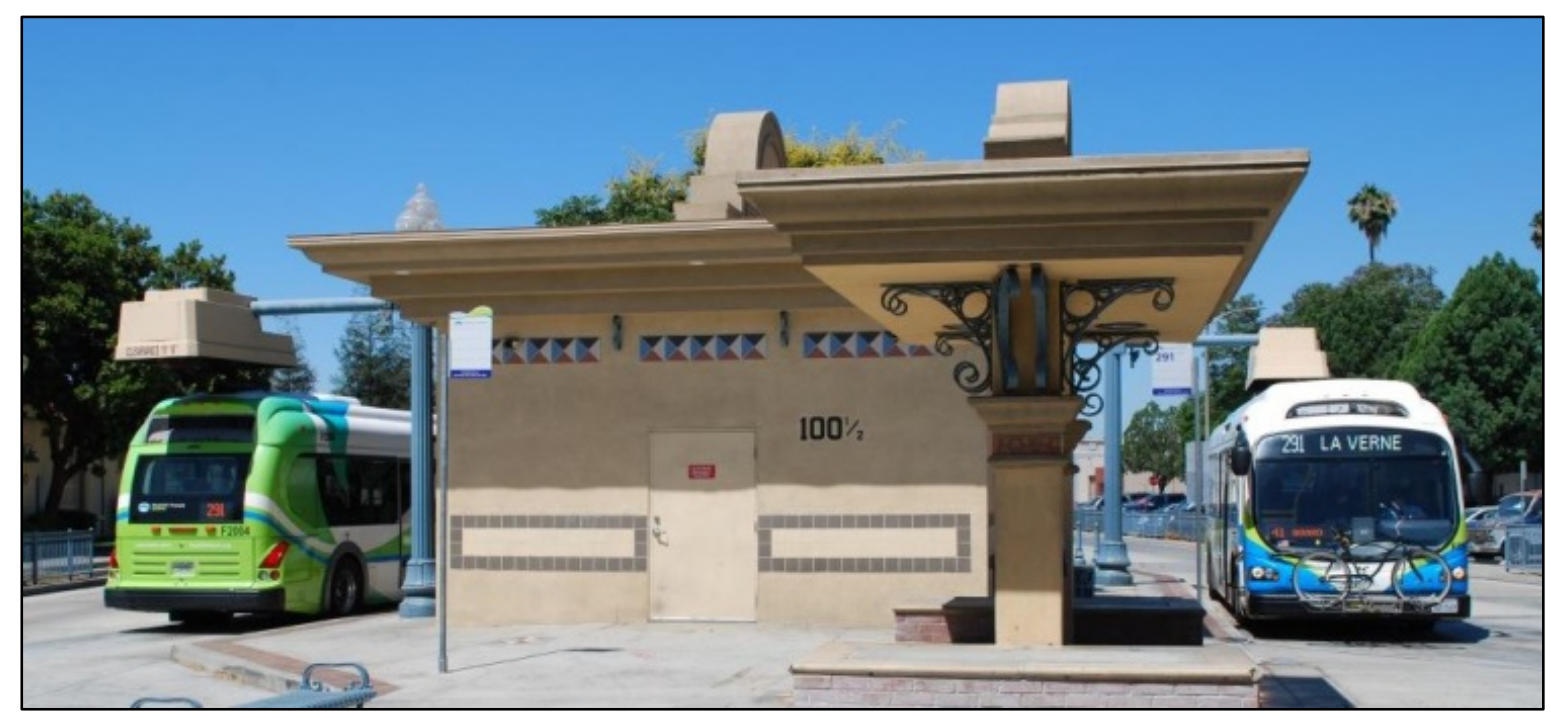

Figure 8. BEB charging station at the PTC

The system can charge two buses simultaneously. Docking a bus with the charging head occurs semi-autonomously, and the operator does not have to exit the bus to make any connections. The system is designed to charge a bus from a partial charge to full in less than 10 minutes. For Foothill Transit's Line 291, typical charge times are around 7 minutes. Foothill Transit built a layover time into the block schedule to allow enough time for charging. Early in the deployment, Foothill Transit entered a contract with Proterra to maintain the chargers and associated equipment. The cost for this service was $\$ 1,500$ per month. Foothill is currently negotiating a new 3-year contract for service on the chargers that includes preventive maintenance at a fixed fee. Foothill Transit will pay Proterra time and materials for any non-scheduled maintenance at a set labor rate. Preventive maintenance covers monthly ( $\$ 500$ per charger), 6-month ( $\$ 1,000$ per charger), and annual ( $\$ 5,200$ per charger) inspections of the overhead fast chargers, including labor and parts.

\subsection{Arcadia Operations and Maintenance Facility}

Foothill Transit introduced BEBs to its second facility in early 2018, when the first buses were delivered. The BEB E2s are designed for plug-in charging as the primary source of power, although the buses are also equipped with a rooftop charging system.

\subsubsection{Arcadia Depot Charging}

The primary means of charging for the BEB E2s is plug-in chargers installed at the Arcadia facility. Foothill Transit installed $1260-\mathrm{kW}$ chargers and one $125-\mathrm{kW}$ charger to accommodate its 17 BEBs. The charging system, which has a capacity for up to 40 chargers, was designed for gantry-style charging with cables that drop down by motorized hose reels from the support structure. The support structure design will allow for adding photovoltaic panels in the future. The system was commissioned in December 2019. Foothill Transit is not currently using software to manage charging; instead, staff manually plug in the BEBs as they return to the facility at the end of each day. Staff try to avoid charging the buses between 4-9 p.m. to minimize peak electricity charges while ensuring all BEBs are recharged prior to morning pullout. Figure 9 shows the overhead structure at Arcadia that supports the 13 plug-in chargers, one 
of which is shown in Figure 10. The new contract with Proterra for charging system maintenance will cover monthly inspections of the plug-in charters at $\$ 125$ per charger.

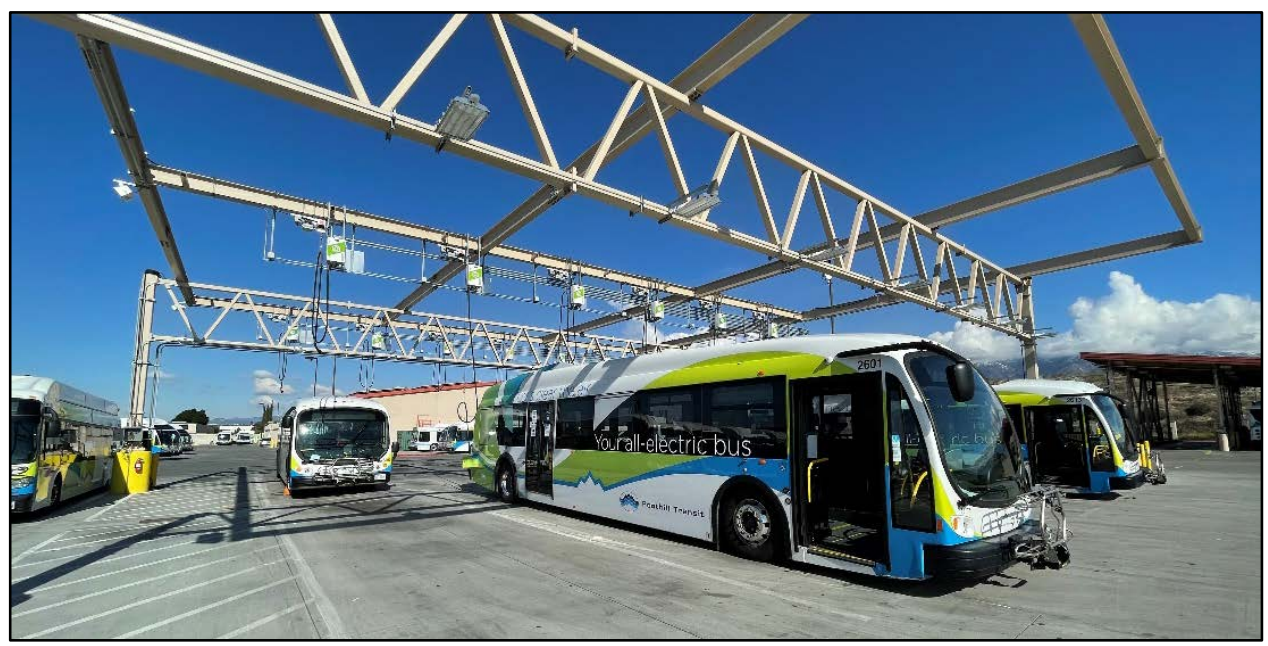

Figure 9. BEB charging structure at Arcadia depot

Photo courtesy of Foothill Transit
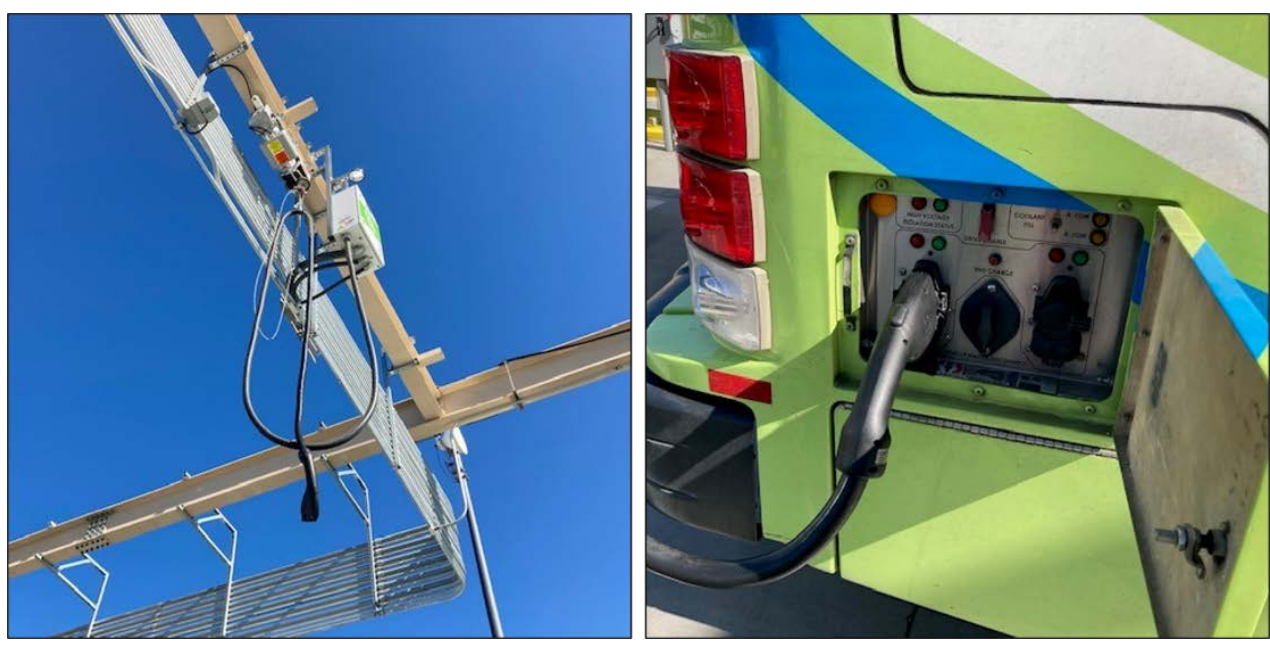

Figure 10. EVSE at Arcadia depot

Photos courtesy of Foothill Transit

\subsubsection{Azusa Intermodal Transit Center Fast-Charge Station}

Foothill Transit installed a second on-route fast-charging station at the Azusa Intermodal Transit Center (AITC) to serve the BEBs operating from the Arcadia facility. The station is similar to the one at the PTC, with two charging heads of the same design and charging power. The BEBs can be charged at this transit center to extend the range of the buses and enable the completion of longer block schedules. The current schedule for the BEB 40E2 fleet includes a 10-minute stop at Azusa, but this can be longer if the driver is at a break period. The BEBs are not charged every time they stop at the transit center. (Note: The BEB 35E2 fleet does not charge at the AITC due to different scheduled routes.) 


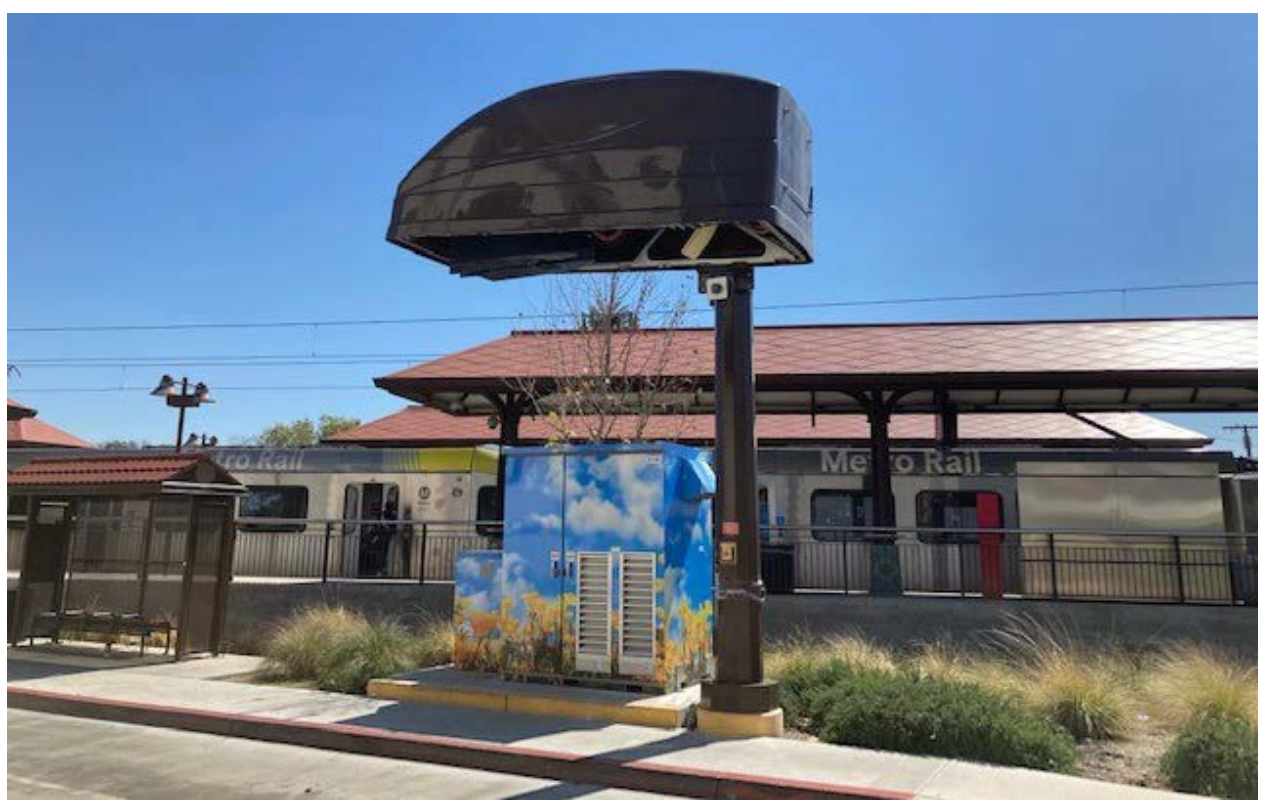

Figure 11. BEB charging station at AITC

Photo courtesy of Foothill Transit 


\section{BEB Evaluation Results: Pomona}

The results presented in this section include analysis of data collected from April 2014 through December 2020 on the two BEB fleets and baseline CNG fleet. In early 2020, one of the BEB $35 \mathrm{FC}$ buses (2004) was significantly damaged and was permanently removed from service. From January 2020, results for this fleet include 11 buses. Data analyzed by NREL for the evaluation included daily mileage and fuel/energy consumption by each bus, daily availability records (readiness for service) for each bus, monthly electric utility bills and CNG fuel bills, and detailed work orders for all non-warranty maintenance performed on the buses. The results sections below examine the scheduled/assigned service for the BEBs and availability for service; mileage, energy consumption, and fuel economy; charging performance and fuel costs; on-road reliability; and detailed maintenance costs. As mentioned previously, low mileage accumulation on the Pomona BEBs during 2020 results in data that are not representative of the fleet operation. For some analyses, anomalous data points have been removed from the charts to avoid scaling issues, but these data are included in the calculations and totals. Appendix $\mathrm{C}$ provides a detailed summary of the Pomona bus operation and costs. Appendix D provides a summary of results in metric units. To enable the reader to understand how 2020 affects the results, the appendices present the overall data for the entire evaluation and for just 2020.

\subsection{Route Assignments}

Foothill Transit's service from the Pomona facility consists of 21 routes: 15 local and six commuter/express routes. The agency operates the BEB fleets primarily on Line 291 . This line is a 16.1-mile route that travels between La Verne and Pomona with minimal deadhead distance from the Pomona facility. The line serves a transit-dependent community and has high ridership. Figure 12 shows the route map for Line 291.

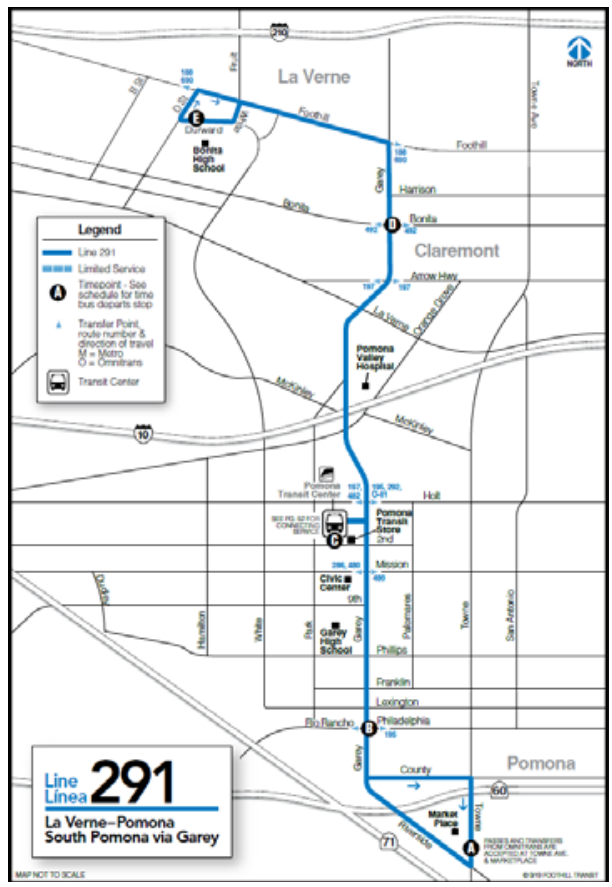

Figure 12. Route map for Line 291

Image courtesy of Foothill Transit 
The route loops through the PTC in both directions, making the PTC an ideal location for the fast-charging station. The agency adjusted the schedule to accommodate time for charging the BEBs. Early in the deployment, Foothill Transit used the BEBs on Line 855 because it also cycled through the PTC. In October 2017, Line 855 was eliminated. From that point, the BEBs were operated only on Line 291. Based on Foothill Transit's schedule, in-service speed for Line 291 is $10.6 \mathrm{mph}$. Average in-service speed for all of Pomona operations is $17.6 \mathrm{mph}$. Figure 13 outlines the difference in route assignment between the BEBs and the CNG buses. The CNG baseline buses are randomly dispatched on all the routes out of the Pomona facility including commuter routes, which results in a higher average speed and greater mileage accumulation than for local routes such as Line 291. Because fuel economy can be highly dependent on duty cycle, this has a significant impact on the fleet-average fuel economy comparison between the BEBs and CNG fleets in this evaluation. Maintenance costs can also vary when comparing the higher mileage CNG fleet with the lower mileage, stop-and-go duty cycle of the BEBs.

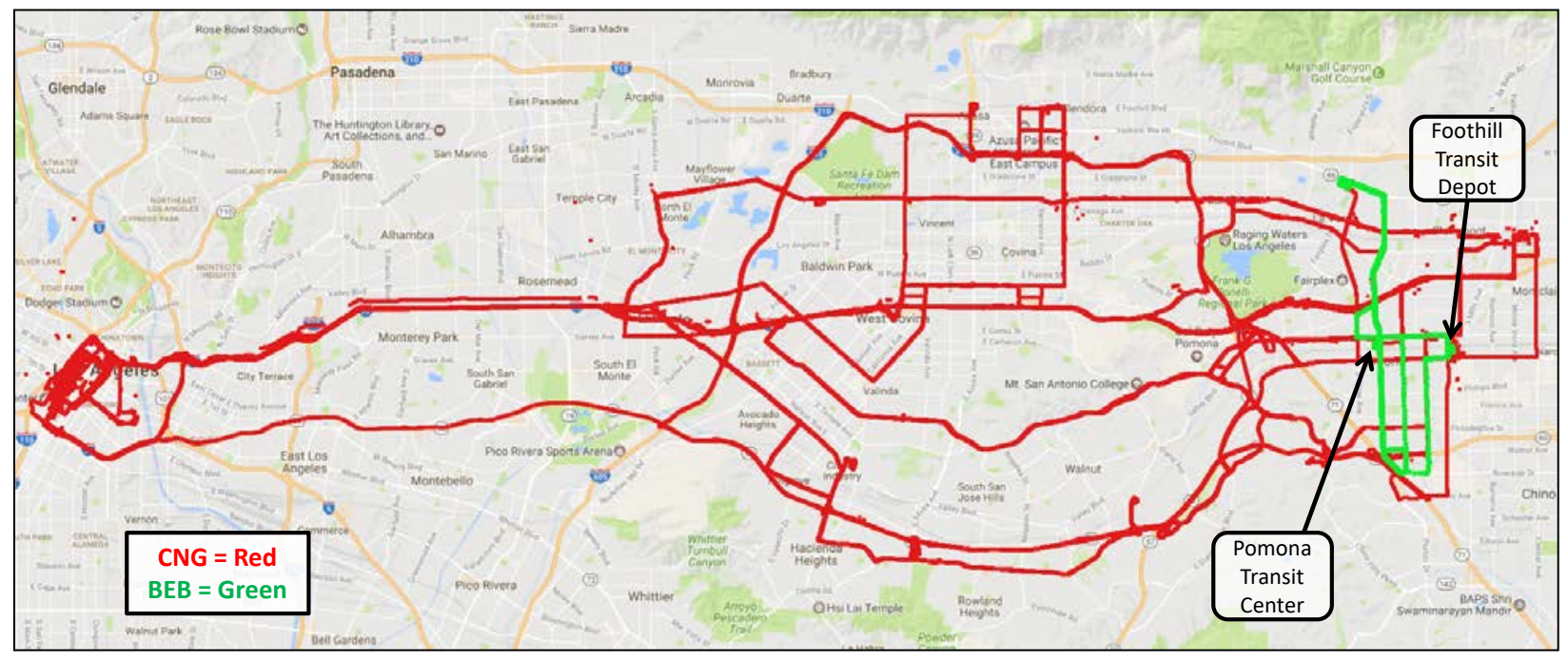

Figure 13. Routes traveled by randomly-dispatched CNG buses (red) and Line 291 traveled by the BEBs (green)

Map data @ 2017 Google

\subsection{Bus Availability}

The availability of a bus for scheduled service is an indicator of reliability. Lower bus availability may indicate downtime for maintenance or purposeful reduction of planned work for the buses. This section summarizes bus usage and availability for the BEBs and baseline buses at Pomona.

NREL calculates bus availability as the percentage of days buses are available for passenger service (whether or not they are used) out of days the buses are planned for service. Buses that are available may be used for passenger service, training, or special events, or they may be available but not used for any purpose. The results presented are based on availability for morning pull-out and do not necessarily reflect all-day availability. Transit agencies typically have a target of $85 \%$ availability for their fleets to allow for time to handle scheduled and unscheduled maintenance. Accidents are removed from the data-the bus is considered "not planned" during the repair time for accident-related repairs. For the Foothill Transit fleet, the 
buses are planned to operate every day, including weekends. To calculate availability for the BEB and CNG fleets, NREL used the daily garage activity sheets for the Pomona facility, which list each bus that is not available for morning pull-out and provide a general reason for unavailability. The garage activity sheets are typically available for weekdays. During the evaluation period, $60 \%$ of the activity sheets were available for NREL's analysis.

The availability is presented as a monthly average for each fleet as well as overall availability. Unavailable time is separated into several categories to show the primary reasons for downtime. Table 4 summarizes the availability for the BEBs during the evaluation period. The per-bus availability ranges from a high of $87.9 \%$ to a low of $67.0 \%$. The overall average is $80.6 \%$ for the BEB 35FC fleet and $76.1 \%$ for the BEB 40FC fleet.

Table 4. Summary of Availability by Bus for the Pomona BEB Fleets

\begin{tabular}{|c|c|c|c|}
\hline Bus ID & $\begin{array}{l}\text { Planned } \\
\text { Days }\end{array}$ & $\begin{array}{l}\text { Available } \\
\text { Days }\end{array}$ & $\begin{array}{l}\text { Percent } \\
\text { Availability }\end{array}$ \\
\hline 2004 & 1,384 & 1,217 & 87.9 \\
\hline 2005 & 1,701 & 1,448 & 85.1 \\
\hline 2006 & 1,727 & 1,458 & 84.4 \\
\hline 2007 & 1,650 & 1,349 & 81.8 \\
\hline 2008 & 1,662 & 1,269 & 76.4 \\
\hline 2009 & 1,675 & 1,375 & 82.1 \\
\hline 2010 & 1,628 & 1,311 & 80.5 \\
\hline 2011 & 1,640 & 1,331 & 81.2 \\
\hline 2012 & 1,641 & 1,308 & 79.7 \\
\hline 2013 & 1,668 & 1,117 & 67.0 \\
\hline 2014 & 1,604 & 1,347 & 84.0 \\
\hline 2015 & 1,639 & 1,289 & 78.6 \\
\hline BEB 35FC Fleet & 19,619 & 15,819 & 80.6 \\
\hline 2016 & 881 & 616 & 69.9 \\
\hline 2017 & 891 & 733 & 82.3 \\
\hline BEB 40FC Fleet & 1,772 & 1,349 & 76.1 \\
\hline
\end{tabular}

Figure 14, Figure 15, and Figure 16 track the monthly availability for the BEB 35FC, BEB $40 \mathrm{FC}$, and CNG fleets, respectively, during the evaluation period. The figures also provide an indication of the reasons for unavailability for each fleet. The stacked bars for each month show the number of days the buses were not available, divided into six categories for the BEBs-Bus Maintenance, Preventive Maintenance (PM), Electric Drive, Energy Storage System (ESS), Charging Issues, and Transmission. The CNG fleet unavailability is divided into four categories - Bus Maintenance, PM, Engine, and Transmission. The general "Bus Maintenance" category includes everything that does not fall into one of the other listed categories and consists primarily of systems that are independent of the bus propulsion system.

The BEB 35FC fleet had consistently high availability during the first few years of the evaluation and began to decline steadily from 2017 through 2020. During the first 2 years of operation, Proterra technicians were permanently on-site to handle warranty work. This resulted in quick repair and fewer days out of service. Most downtime was due to general bus maintenance issues, which increased in the last few years as availability declined. The bus fleet 
experienced some scattered issues with the ESS and electric drive systems early in the evaluation period, and then saw significantly more problems with these systems throughout 2019 and early 2020. Charging issues at the end of 2020 were due to damage to the rooftop charging system on the buses (described in Section 4.6.5). The monthly availability trend for the BEB 40FC fleet, which consists of only two buses, is much more sensitive to fluctuations in bus availability and downtime. This small fleet also had declines in the last few years after showing higher initial availability, similar to the BEB 35FC fleet. Issues with the rooftop charging system on several buses (from both BEB 35FC and BEB 40FC fleets) resulted in low availability for several months in 2020. The CNG fleet had very high availability during the first 4 years of the evaluation, declining only slightly in the last 2 years due to a combination of issues with engines, transmissions, and general bus maintenance as the buses continue to age.

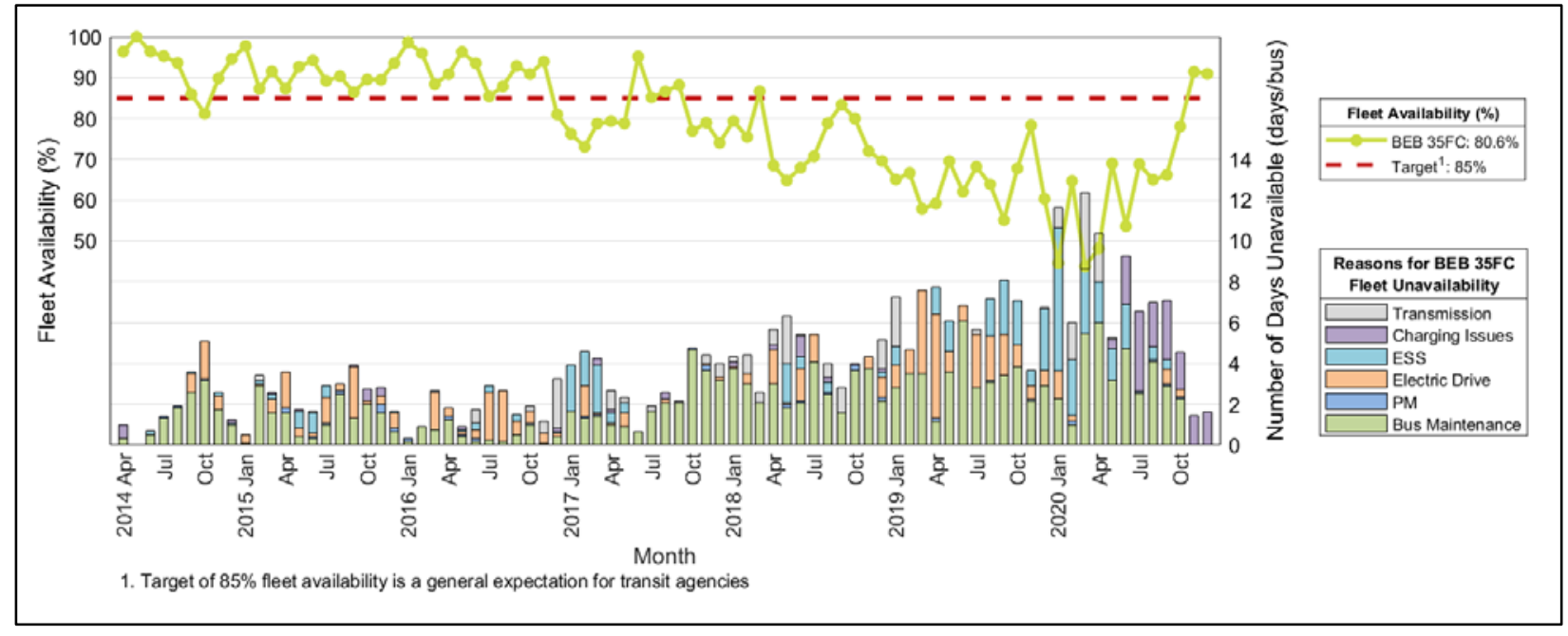

Figure 14. Monthly availability for the BEB 35FC fleet

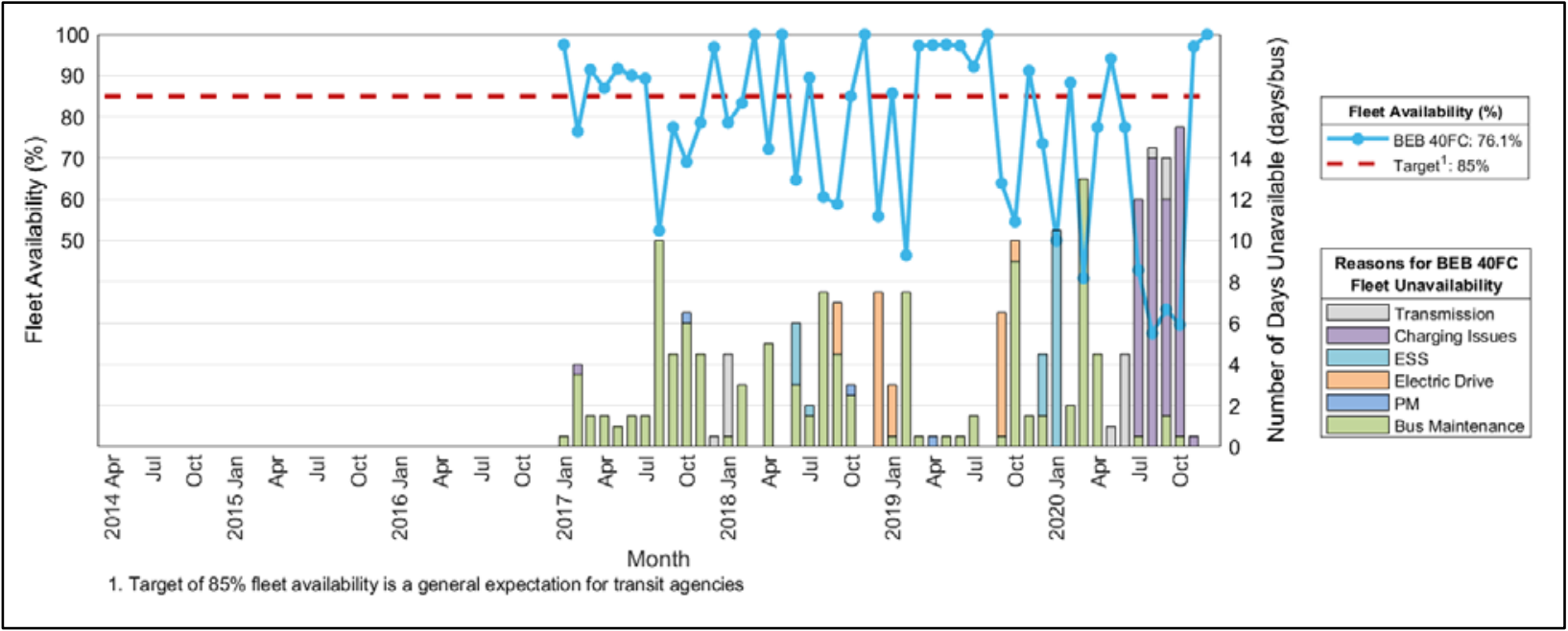

Figure 15. Monthly availability for BEB 40FC fleet 


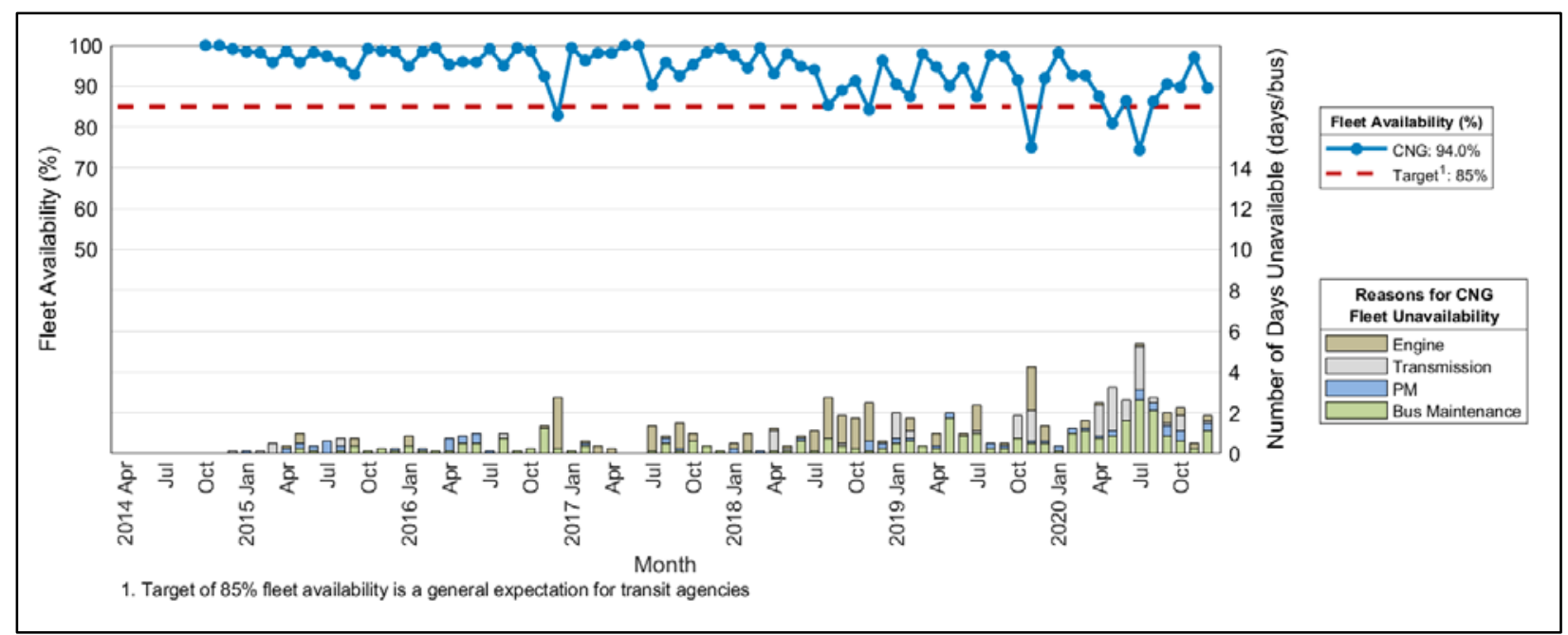

Figure 16. Monthly availability for the CNG fleet

Table 5 and Figure 17 show a summary of the cumulative availability and the unavailability by category for the three Pomona fleets. For both BEB fleets, approximately half of all downtime was related to general bus maintenance; the remaining half is distributed among electric drive, ESS, and charging-related issues.

Table 5. Summary of Availability and Unavailable Days for the Pomona BEB and CNG Fleets

\begin{tabular}{|l|c|c|c|c|c|c|}
\multicolumn{1}{c}{} & \multicolumn{2}{c}{ BEB 35FC } & \multicolumn{2}{c}{ BEB 40FC } & \multicolumn{2}{c|}{ CNG } \\
\cline { 2 - 8 } \multicolumn{1}{c}{ \# Dategory } & \#ays & $\%$ & \# Days & $\%$ & \# Days & $\%$ \\
\hline Planned work days & $\mathbf{1 9 , 6 1 9}$ & - & $\mathbf{1 , 7 7 2}$ & - & $\mathbf{1 0 , 8 3 6}$ & - \\
\hline Available days & 15,819 & 80.6 & 1,349 & 76.1 & 10,183 & 94.0 \\
\hline Unavailable days & $\mathbf{3 , 8 0 0}$ & $\mathbf{1 9 . 4}$ & $\mathbf{4 2 3}$ & $\mathbf{2 3 . 9}$ & $\mathbf{6 5 3}$ & $\mathbf{6 . 0}$ \\
\hline ESS & 568 & 2.9 & 34 & 1.9 & - & - \\
\hline CNG engine & - & - & - & - & 199 & 1.8 \\
\hline Electric drive & 677 & 3.5 & 39 & 2.2 & - & - \\
\hline Charging issues & 241 & 1.2 & 104 & 5.9 & - & - \\
\hline Preventive maintenance & 50 & 0.3 & 3 & 0.2 & 80 & 0.7 \\
\hline General bus maintenance & 1,951 & 9.9 & 218 & 12.3 & 254 & 2.3 \\
\hline Transmission & 313 & 1.6 & 25 & 1.4 & 120 & 1.1 \\
\hline
\end{tabular}




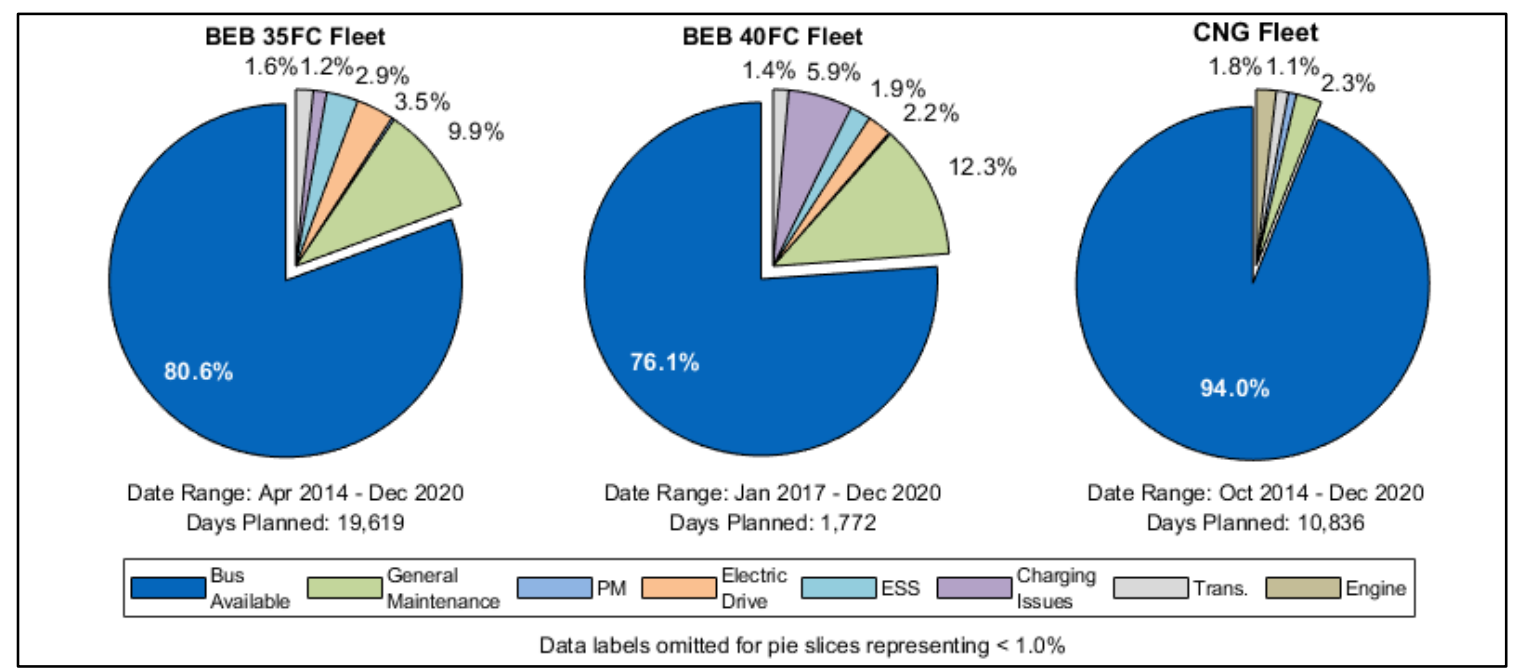

Figure 17. Cumulative availability for the Pomona BEB and CNG fleets

\subsection{Bus Mileage, Energy Use, and Fuel Economy}

Since the beginning of the evaluation period, the BEB 35FC fleet (12 buses) operated for more than 1,772,000 miles in 81 months of service. Entering service in January 2017, the BEB 40FC fleet (two buses) operated for more than 153,000 miles in 48 months of service. Figure 18 shows the cumulative mileage trends for the two fleets, which were both used steadily from the time Foothill Transit deployed them in service until the early part of 2020.

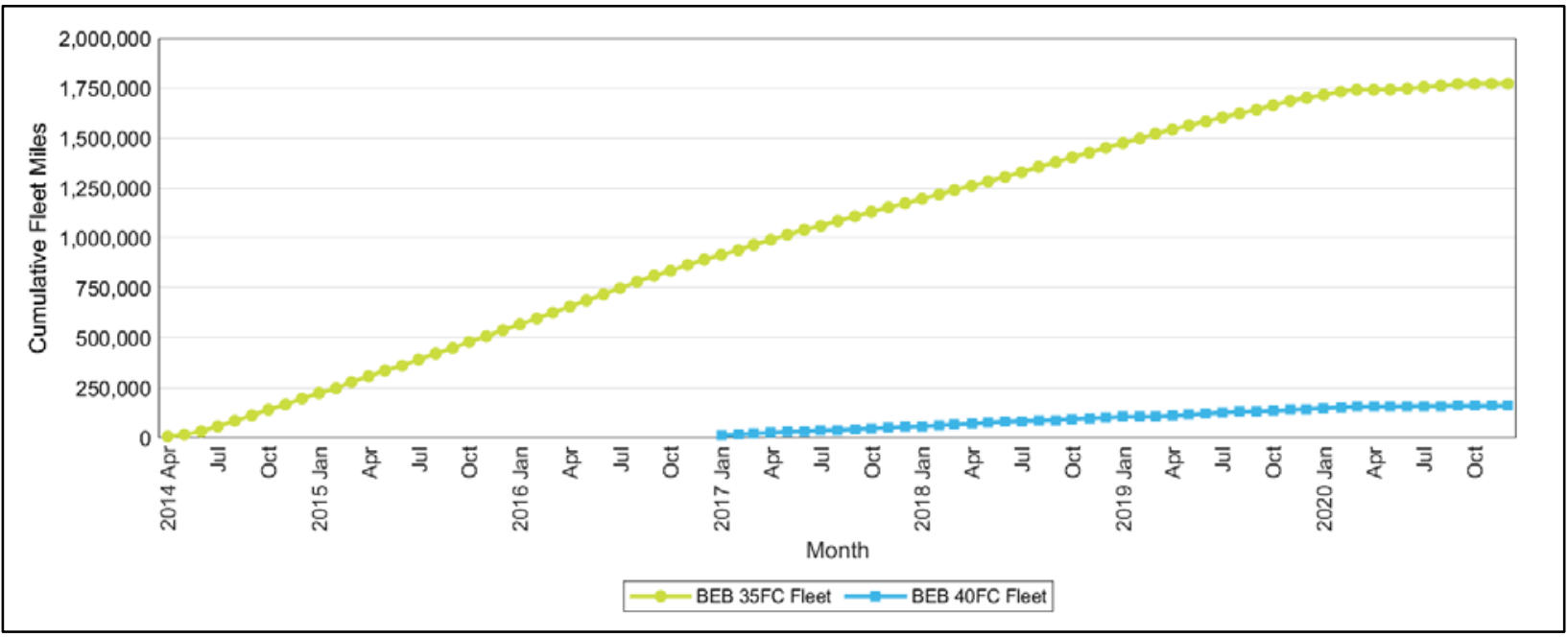

Figure 18. Cumulative miles for the Pomona BEB fleets

Table 6 and Table 7 summarize the overall mileage for each bus in the BEB and CNG fleets, respectively. Figure 19 compares the average monthly mileage trends between the three fleets. Overall, the average monthly mileage per bus during the evaluation period was 1,885 miles for the BEB 35FC fleet and 1,594 miles for the BEB 40FC fleet. The CNG buses accumulated 4,606 miles per month, on average - significantly more than the BEBs. This difference is the expected result of the scheduled operation of these fleets. The BEBs are operated exclusively on Line 291 and the CNG buses are randomly dispatched on all routes out of the Pomona facility, including 
express and commuter routes that have much higher average speeds. In addition, the operating hours of the scheduled blocks may be different between the fleets.

Monthly mileage trends were relatively consistent for most of the evaluation period. The BEB $35 \mathrm{FC}$ fleet experienced a slight decrease in average monthly miles after 2016, yet remained near 2,000 miles per bus per month until 2020. All fleets experienced a drastic decline in operation in 2020 when service was disrupted by the COVID-19 pandemic. After a few months, the CNG fleet operation returned to normal. Although BEB operation began to recover as service was restored, issues with the buses and downtime of the charger at PTC resulted in very restricted use of the BEBs during the remainder of 2020. The BEB fleets accumulated very few or zero miles during several months of 2020. This low mileage had a significant impact on the analysis, and in some cases required outlier data points be removed from charts in this report, for calculated metrics such as fuel economy (kWh per mile, miles per gallon), fuel cost per mile, and maintenance cost per mile.

Table 6. Average Monthly Miles, BEB Fleets

\begin{tabular}{|c|c|c|c|c|}
\hline Bus ID & $\begin{array}{l}\text { Start } \\
\text { Month }\end{array}$ & Miles & $\begin{array}{c}\text { Bus } \\
\text { Months }\end{array}$ & $\begin{array}{c}\text { Average } \\
\text { Monthly Miles }\end{array}$ \\
\hline $2004^{a}$ & April 2014 & 140,363 & 69 & 2,034 \\
\hline 2005 & April 2014 & 157,628 & 81 & 1,946 \\
\hline 2006 & April 2014 & 155,491 & 81 & 1,920 \\
\hline 2007 & July 2014 & 149,091 & 78 & 1,911 \\
\hline 2008 & June 2014 & 147,522 & 79 & 1,867 \\
\hline 2009 & June 2014 & 164,316 & 79 & 2,080 \\
\hline 2010 & June 2014 & 153,130 & 79 & 1,938 \\
\hline 2011 & June 2014 & 144,789 & 79 & 1,833 \\
\hline 2012 & June 2014 & 147,865 & 79 & 1,872 \\
\hline 2013 & June 2014 & 114,170 & 79 & 1,445 \\
\hline 2014 & July 2014 & 160,798 & 78 & 2,062 \\
\hline 2015 & June 2014 & 136,920 & 79 & 1,733 \\
\hline BEB 35FC Fleet & & $1,772,084$ & 940 & 1,885 \\
\hline 2016 & Jan. 2017 & 70,885 & 48 & 1,477 \\
\hline 2017 & Jan. 2017 & 82,120 & 48 & 1,711 \\
\hline BEB 40FC Fleet & & 153,005 & 96 & 1,594 \\
\hline
\end{tabular}

a Bus 2004 was retired from service in January 2020.

Table 7. Average Monthly Miles, CNG Fleet

\begin{tabular}{|c|c|c|c|c|}
\hline Bus ID & \multicolumn{1}{c}{$\begin{array}{c}\text { Start } \\
\text { Month }\end{array}$} & Miles & $\begin{array}{c}\text { Bus } \\
\text { Months }\end{array}$ & $\begin{array}{c}\text { Average } \\
\text { Monthly Miles }\end{array}$ \\
\hline 2200 & Oct. 2014 & 348,085 & 75 & 4,641 \\
\hline 2201 & Oct. 2014 & 322,333 & 75 & 4,298 \\
\hline 2202 & Oct. 2014 & 350,310 & 75 & 4,671 \\
\hline 2203 & Oct. 2014 & 348,350 & 75 & 4,645 \\
\hline 2204 & Oct. 2014 & 331,246 & 75 & 4,417 \\
\hline 2205 & Oct. 2014 & 351,153 & 75 & 4,682 \\
\hline 2206 & Oct. 2014 & 356,190 & 75 & 4,749 \\
\hline 2207 & Oct. 2014 & 356,079 & 75 & 4,748 \\
\hline CNG Fleet & & $\mathbf{2 , 7 6 3 , 7 4 6}$ & $\mathbf{6 0 0}$ & $\mathbf{4 , 6 0 6}$ \\
\hline
\end{tabular}




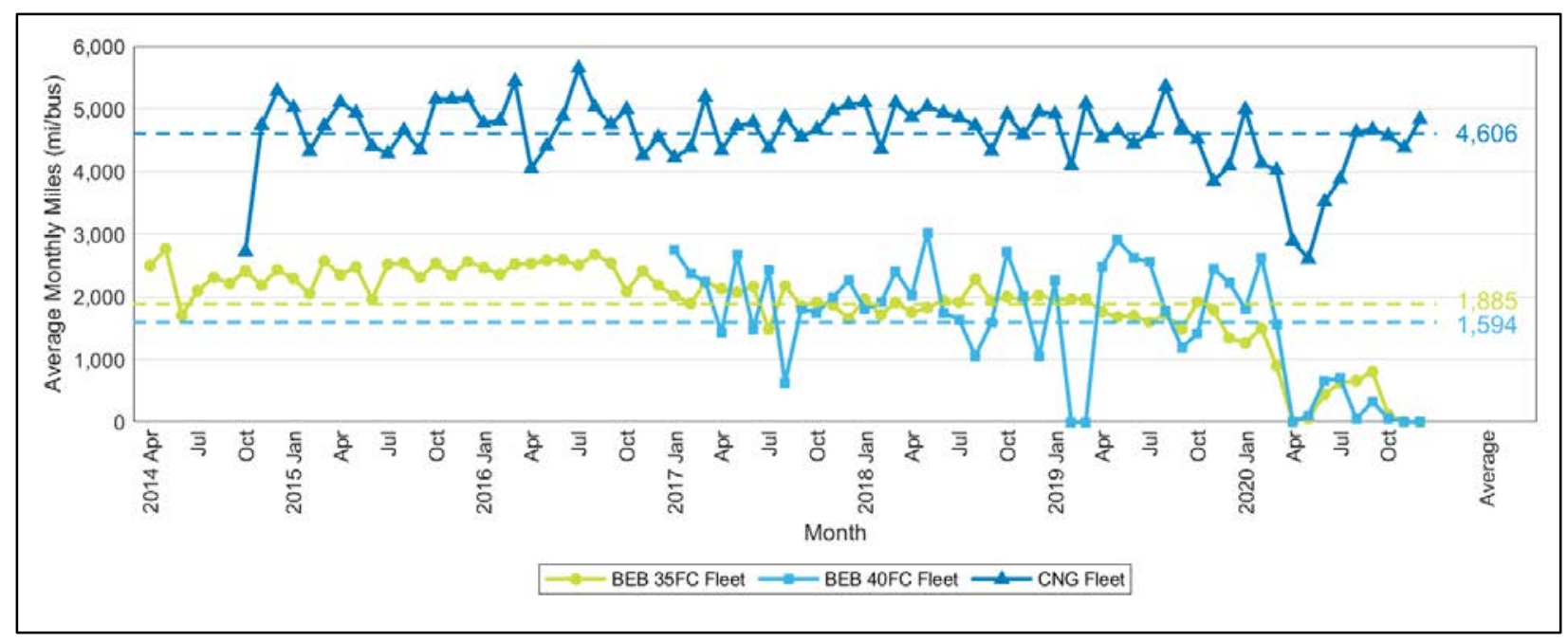

Figure 19. Average monthly miles for the Pomona BEB and CNG fleets

The BEBs at Pomona are charged frequently throughout the day as they operate on Line 291. NREL receives data summaries of daily mileage and energy consumption for each bus, which are used to calculate performance metrics such as fuel economy. The CNG buses are normally fueled once each day, and the fueling records are provided by Foothill Transit. CNG fuel is typically tracked in units of gasoline gallon equivalent (gge). To compare the BEBs to the CNG buses, NREL converted the CNG fuel energy from gge to diesel gallon equivalent (dge) using a conversion factor of 1.146 gge/dge and converted the electrical energy of the BEBs from $\mathrm{kWh}$ to dge using a conversion factor of $37.64 \mathrm{kWh} /$ dge. More information on the energy conversions is provided in Appendix B.

Table 8 shows mileage, energy consumption, and the resulting fuel economy for each BEB during the evaluation period. Table 9 shows the comparable results for each of the CNG buses. The BEB fleets had overall average efficiencies of $2.15 \mathrm{kWh}$ per mile for BEB 35FC and 2.10 $\mathrm{kWh}$ per mile for BEB 40FC, which equate to diesel-equivalent fuel economies of 17.47 miles per diesel gallon equivalent (mpdge) and 17.96 mpdge, respectively. The $\mathrm{CNG}$ fleet had an average diesel-equivalent fuel economy of 4.29 mpdge. The BEB fuel economies are approximately four times higher than the CNG fleet fuel economy. As previously mentioned, the CNG and BEB fleets are operated in different service, which influences the fuel economy. NREL previously reported that CNG buses operating on Line 291 would have a fuel economy closer to 2 mpdge ${ }^{2}$.

\footnotetext{
${ }^{2}$ https://www.nrel.gov/docs/fy17osti/67698.pdf
} 
Table 8. Energy Use and Fuel Economy for the BEB Fleets ${ }^{3}$

\begin{tabular}{|c|c|c|c|c|c|}
\hline Bus ID & $\begin{array}{l}\text { Fuel } \\
\text { Miles }\end{array}$ & $\begin{array}{c}\text { Fuel } \\
\text { Consumption } \\
\text { (kWh) }\end{array}$ & $\begin{array}{c}\text { Fuel } \\
\text { Consumption } \\
\text { (dge) }\end{array}$ & $\begin{array}{l}\text { Fuel Economy } \\
\text { (kWh/mi) }\end{array}$ & $\begin{array}{l}\text { Fuel Economy } \\
\text { (mpdge) }\end{array}$ \\
\hline 2004 & 136,024 & 290,549 & 7,720 & 2.14 & 17.62 \\
\hline 2005 & 153,037 & 334,668 & 8,892 & 2.19 & 17.21 \\
\hline 2006 & 150,020 & 330,923 & 8,793 & 2.21 & 17.06 \\
\hline 2007 & 145,572 & 316,518 & 8,410 & 2.17 & 17.31 \\
\hline 2008 & 143,969 & 320,209 & 8,508 & 2.22 & 16.92 \\
\hline 2009 & 159,493 & 340,079 & 9,036 & 2.13 & 17.65 \\
\hline 2010 & 152,064 & 325,543 & 8,650 & 2.14 & 17.58 \\
\hline 2011 & 140,189 & 294,317 & 7,820 & 2.10 & 17.93 \\
\hline 2012 & 142,704 & 301,231 & 8,004 & 2.11 & 17.83 \\
\hline 2013 & 111,994 & 229,276 & 6,092 & 2.05 & 18.38 \\
\hline 2014 & 156,302 & 329,728 & 8,761 & 2.11 & 17.84 \\
\hline 2015 & 136,669 & 309,464 & 8,223 & 2.26 & 16.62 \\
\hline $\begin{array}{l}\text { BEB 35FC } \\
\text { Fleet }\end{array}$ & $1,728,036$ & $3,722,506$ & 98,909 & 2.15 & 17.47 \\
\hline 2016 & 35,928 & 75,748 & 2,013 & 2.11 & 17.85 \\
\hline 2017 & 43,991 & 91,714 & 2,437 & 2.08 & 18.05 \\
\hline $\begin{array}{l}\text { BEB 40FC } \\
\text { Fleet }\end{array}$ & 79,918 & 167,461 & 4,450 & 2.10 & 17.96 \\
\hline
\end{tabular}

Table 9. Energy Use and Fuel Economy for the CNG Fleet

\begin{tabular}{|c|c|c|c|c|c|}
\hline Bus ID & $\begin{array}{c}\text { Fuel } \\
\text { Miles }\end{array}$ & $\begin{array}{c}\text { Fuel } \\
\text { Consumption } \\
\text { (gge) }\end{array}$ & $\begin{array}{c}\text { Consumption } \\
\text { (dge) }\end{array}$ & $\begin{array}{c}\text { Fuel Economy } \\
\text { (mpgge) }\end{array}$ & $\begin{array}{c}\text { Fuel Economy } \\
\text { (mpdge) }\end{array}$ \\
\hline 2200 & 311,256 & 81,895 & 71,459 & 3.80 & 4.36 \\
\hline 2201 & 285,314 & 79,223 & 69,127 & 3.60 & 4.13 \\
\hline 2202 & 307,261 & 79,748 & 69,585 & 3.85 & 4.42 \\
\hline 2203 & 308,518 & 82,715 & 72,174 & 3.73 & 4.27 \\
\hline 2204 & 292,113 & 79,558 & 69,419 & 3.67 & 4.21 \\
\hline 2205 & 307,333 & 80,633 & 70,358 & 3.81 & 4.37 \\
\hline 2206 & 310,390 & 83,213 & 72,608 & 3.73 & 4.27 \\
\hline 2207 & 317,237 & 84,419 & 73,661 & 3.76 & 4.31 \\
\hline CNG Fleet & $\mathbf{2 , 4 3 9 , 4 2 2}$ & $\mathbf{6 5 1 , 4 0 4}$ & $\mathbf{5 6 8 , 3 9 2}$ & $\mathbf{3 . 7 4}$ & $\mathbf{4 . 2 9}$ \\
\hline
\end{tabular}

${ }^{a}$ Miles per gasoline gallon equivalent

Fuel economy is an important factor in the operating costs of the buses, and it can be impacted by several factors including duty cycle, ambient conditions (requiring heating or cooling), vehicle weight, and driver behavior. The monthly average fuel economy trends for the three Pomona fleets are shown in Figure 20, along with the monthly average high temperature near Pomona to track seasonal variation. The BEBs are significantly more energy-efficient than the CNG fleet but also more sensitive to changes in ambient temperature, which causes the fuel economy to vary seasonally.

\footnotetext{
${ }^{3}$ Average speed for the BEBs was 10.7 mph compared to 17.9-mph average speed for the CNG buses.
} 


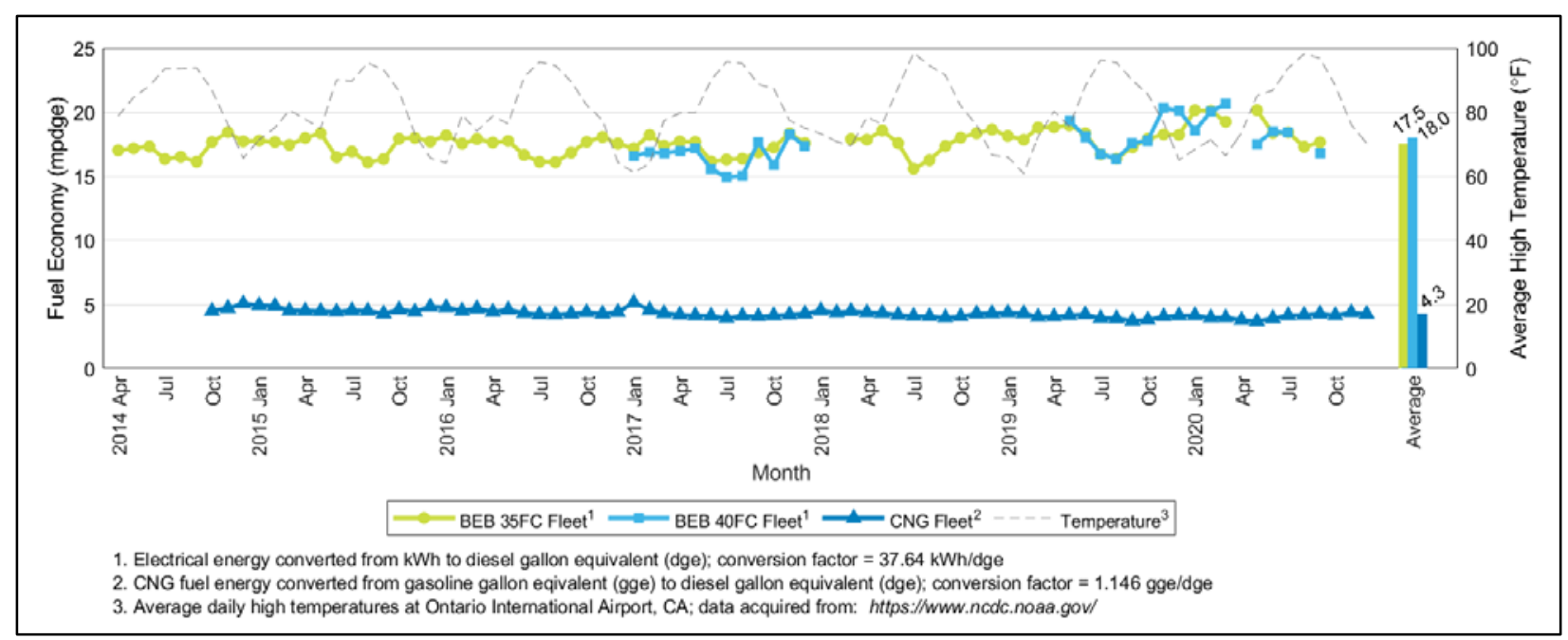

Figure 20. Monthly average fuel economy for the BEB and CNG fleets

Figure 21 plots the median daily fuel economy of the BEBs as a function of daily average ambient temperature. The peak fuel economy occurs between $60^{\circ} \mathrm{F}$ and $70^{\circ} \mathrm{F}$ and decreases for higher and lower temperatures as energy requirements for heating and cooling increase. Although the ambient conditions in Foothill Transit's service area are relatively mild throughout the year compared to many other cities, the higher temperatures have a considerable effect on BEB fuel economy.

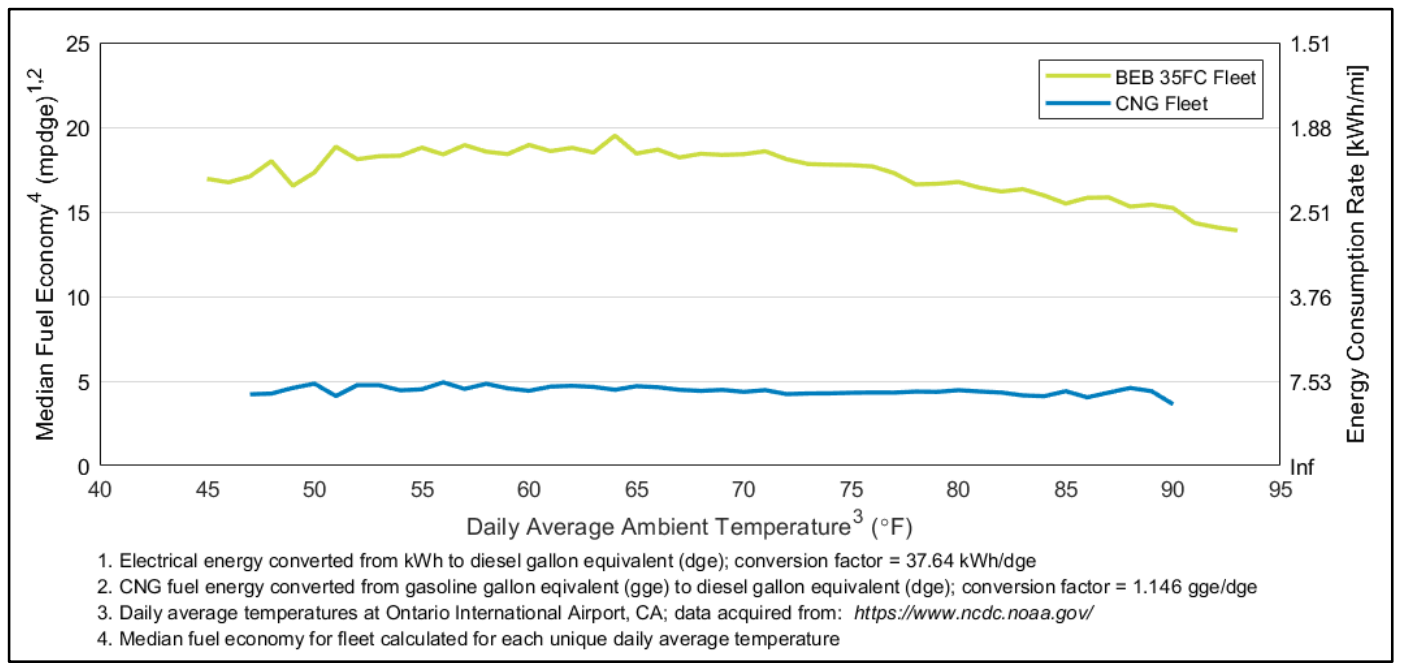

Figure 21. Impact of ambient temperature on median fuel economy

\subsection{Charging Performance and Fuel Cost}

Foothill Transit's charging station at PTC was installed with a dedicated utility meter for the chargers to help quantify the electrical energy used to fuel the BEBs, separate from other electrical loads at the charging station. Foothill Transit provided energy consumption data and monthly utility bills to NREL for analysis of the charging behavior and energy costs.

The fast-charge BEBs operating on Line 291 use on-route charging, allowing them to continue operating as long as the route schedule dictates, subject to charger and driver availability. Each 
BEB is typically charged every time it stops at the PTC, although it is possible for the BEBs to complete more than one lap of the route before needing to recharge. This charging strategy results in up to 20 charges per day for BEBs traveling up to 150 miles per day. Charging duration is typically between 5 and 10 minutes, as indicated by the distribution in Figure 22. The inset plot in the figure shows the state of charge (SOC, \%) of the battery pack at the start of numerous fast-charging events - the SOC is typically around $60 \%$ or $80 \%$, depending on the number of route laps completed since last charge. The plot also shows the SOC at the end of the charging events, indicating the battery is usually above $80 \%$ SOC and very often near a full charge $(100 \%$ SOC).

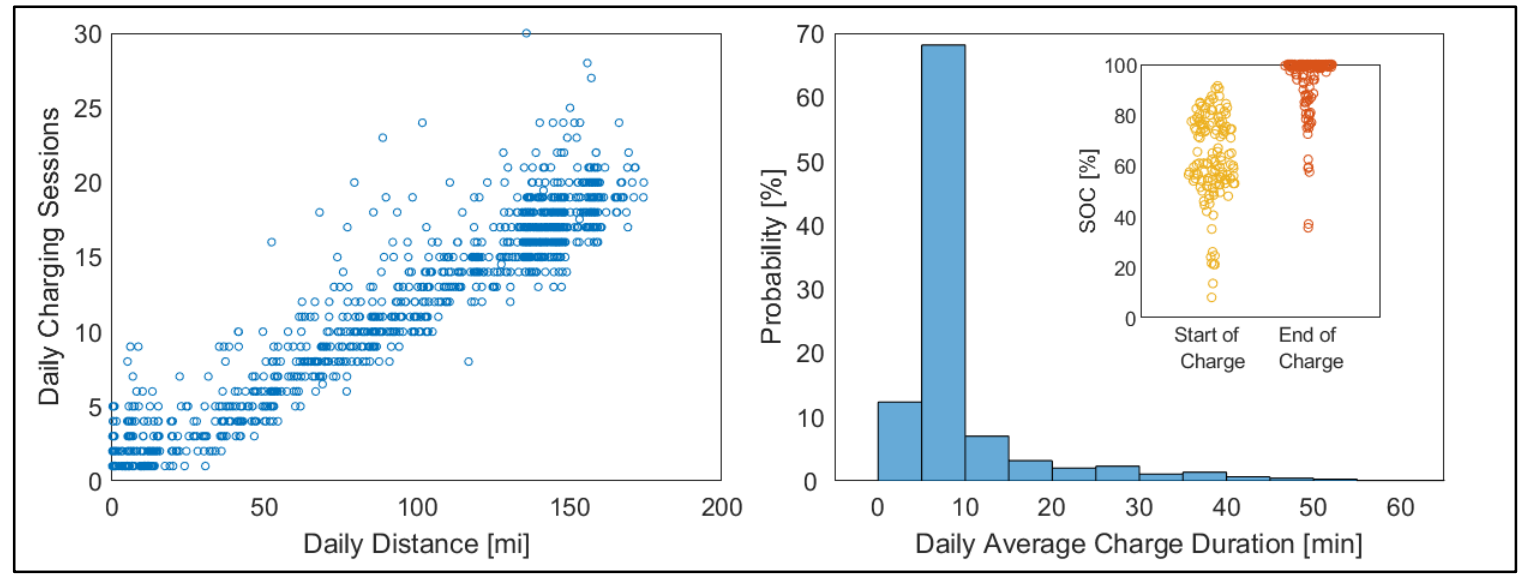

Figure 22. Number of daily charges and average charge duration for the Pomona BEBs

Because the Pomona BEBs operate continuously throughout the day and only one BEB can charge at each of the two fast chargers at a time, the overall electrical load is spread out throughout the day. Figure 23 shows the daily charging profile of the BEB fleet as measured by the electrical meter at the PTC charging station. The charging power for each day, reported in 15-minute increments, is displayed by overlapping translucent columns, which stack up to reveal the typical daily charging profile for the BEB operation overall. The figure also displays trend lines for median charging power for weekday and weekend operations, which have different route service levels. This BEB fleet draws electricity during all time-of-use (TOU) periods defined by the utility rate structure, which can affect electricity costs significantly. 


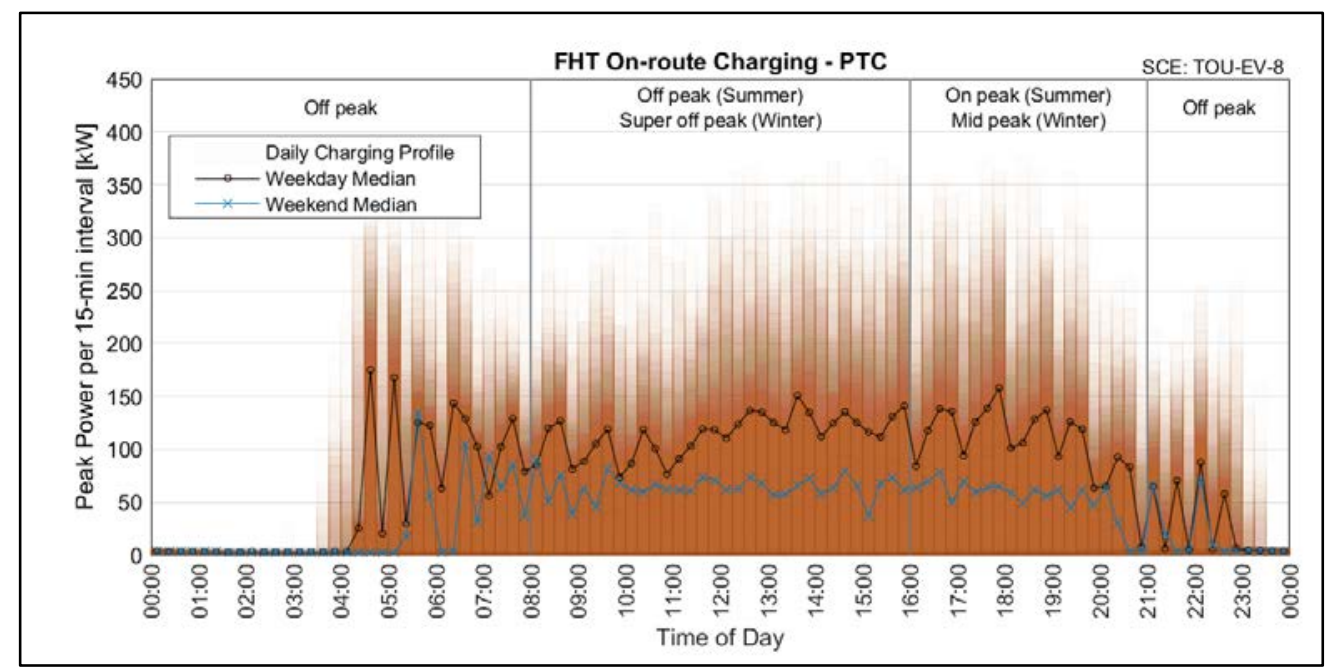

Figure 23. Daily charging profile for BEB fleet at PTC

Foothill Transit's electric utility, Southern California Edison (SCE), has implemented several rate structures to govern the costs of the PTC chargers since the BEBs began operating in 2014. The rate schedules have prescribed a combination of TOU and demand charges. When the first three BEBs were deployed, Proterra and Foothill Transit were concerned that the maximum electricity demand would exceed $500 \mathrm{~kW}$ because the two fast chargers at the station are each rated for $500 \mathrm{~kW}$ and exceeding this level would trigger a move onto an industrial rate schedule (TOU-8), ${ }^{4}$ which had high demand charges. Proterra petitioned the California Public Utilities Commission to help address this issue for Foothill Transit and other transit agencies considering fast-charge buses. The California Public Utilities Commission issued resolution E-4514, ${ }^{5}$ which allowed Foothill Transit to stay on the small commercial schedule (TOU-GS-1) ${ }^{6}$ that had no demand charges. Typically, this rate schedule is only applicable to customers that demand less than $20 \mathrm{~kW}$. That exemption expired at the end of 2015. SCE established new rate schedules specifically for commercial customers using electric vehicles. TOU-EV-4 ${ }^{7}$ was applicable to customers whose monthly demand is between $20 \mathrm{~kW}$ and $500 \mathrm{~kW}$. Foothill Transit worked with Proterra to implement charge management software that limits the total charging demand to less than the $500-\mathrm{kW}$ threshold, helping to prevent higher electricity costs. In early 2019, SCE implemented commercial electric vehicle rate schedules that exclude demand charges for 5 years (2019-2023), but plan to phase them back in slowly in the subsequent 5 years. This is intended to encourage commercial customers, including transit agencies, to transition their fleets to electric vehicles.

Figure 24 shows the monthly unit cost of electricity $(\$ / \mathrm{kWh})$ for each rate structure during the evaluation period. The costs are color-coded by TOU periods and demand charges. Electricity is

\footnotetext{
${ }^{4}$ https://library.sce.com/content/dam/sce-doclib/public/regulatory/tariff/electric/schedules/general-service- \&industrial-rates/ELECTRIC SCHEDULES TOU-8.pdf

${ }^{5}$ http://docs.cpuc.ca.gov/publisheddocs/published/g000/m032/k702/32702823.pdf

${ }^{6}$ https://library.sce.com/content/dam/sce-doclib/public/regulatory/tariff/electric/schedules/general-service- $\&$ industrial-rates/ELECTRIC SCHEDULES TOU-GS-1.pdf

${ }^{7}$ https://library.sce.com/content/dam/sce-doclib/public/regulatory/tariff/electric/schedules/general-service- \&industrial-rates/ELECTRIC SCHEDULES_TOU-EV-4.pdf
} 
more expensive during summer months, which causes seasonal fluctuation in the costs regardless of demand charges. (Note: 2020 data for months with very low electricity consumption were removed from the figure as monthly taxes/fees account for a disproportionate fraction of the monthly utility costs and the calculated $\$ / \mathrm{kWh}$ value is anomalously high as a result.)

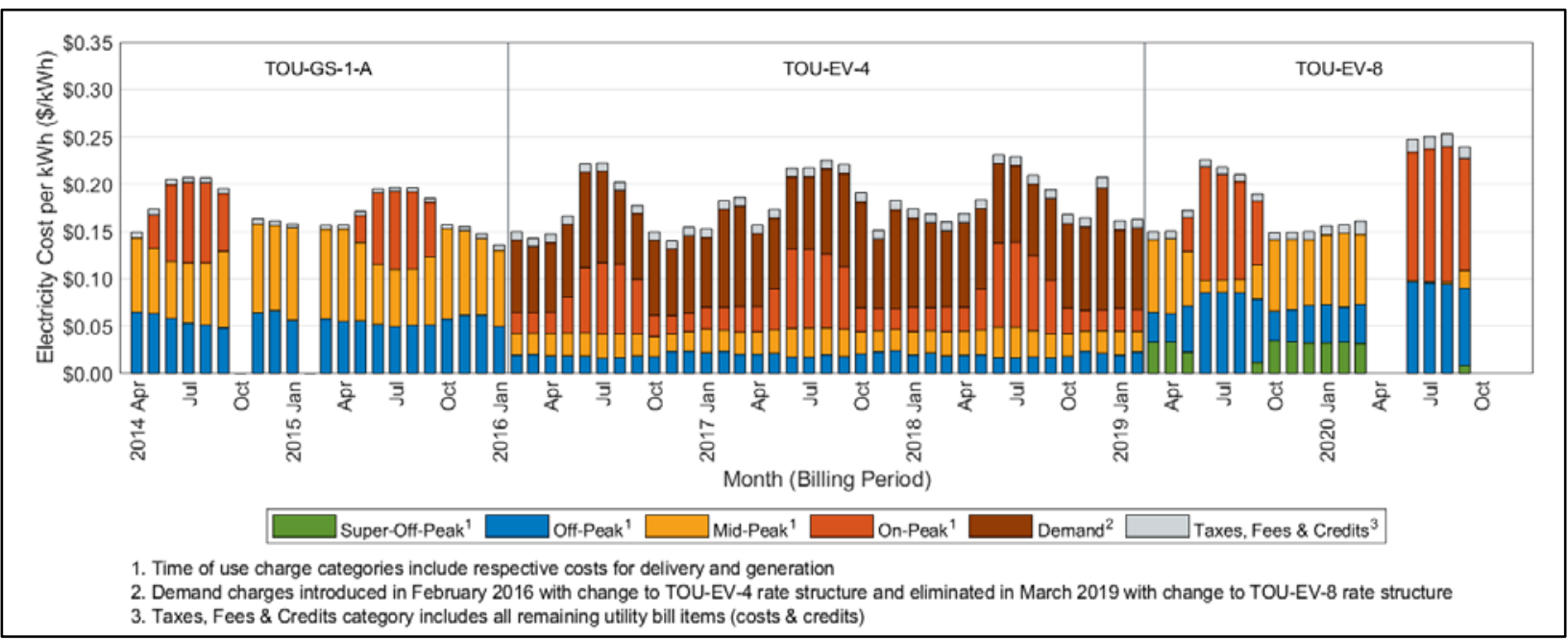

Figure 24. Monthly average electricity cost for PTC charging

Table 10 summarizes the average electricity price for each rate structure, as well as winter and summer averages for the full evaluation period. The seasonal averages are $\$ 0.21$ per $\mathrm{kWh}$ during summer months (June-September) and $\$ 0.16$ per kWh during winter (October-May). The average price under the current rate structure, TOU-EV-8, is $\$ 0.23$ per $\mathrm{kWh}$, which translates to a diesel-equivalent fuel price of $\$ 8.82$ per dge.

Table 10. Average Electricity Price for PTC Charging

\begin{tabular}{|c|c|c|c|c|c|}
$\begin{array}{c}\text { Average } \\
\begin{array}{c}\text { Electricity } \\
\text { Price }\end{array}\end{array}$ & TOU-GS-1-A & TOU-EV-4 & TOU-EV-8 & $\begin{array}{c}\text { Summer } \\
\text { Average } \\
\text { (June-Sept.) }\end{array}$ & $\begin{array}{c}\text { Winter } \\
\text { Average } \\
\text { (Oct-May) }\end{array}$ \\
\hline \$/kWh & 0.17 & 0.18 & 0.23 & 0.21 & 0.16 \\
\hline \$/dge & 6.55 & 6.84 & 8.82 & 7.90 & 6.08 \\
\hline
\end{tabular}

Fuel costs to operate the CNG bus fleet include the commodity cost of the CNG fuel as well as the costs for operations and maintenance (O\&M) of the CNG fueling station for the Pomona fleet. Figure 25 tracks the monthly unit cost for CNG fuel during the evaluation period, indicating the commodity and O\&M portions. There were a few months when limitations in regional CNG supply caused temporary price increases, and station O\&M costs have increased slightly during 2020, contributing to higher CNG prices. Otherwise, the monthly price has remained relatively consistent during the evaluation, averaging $\$ 1.21$ per dge overall. 


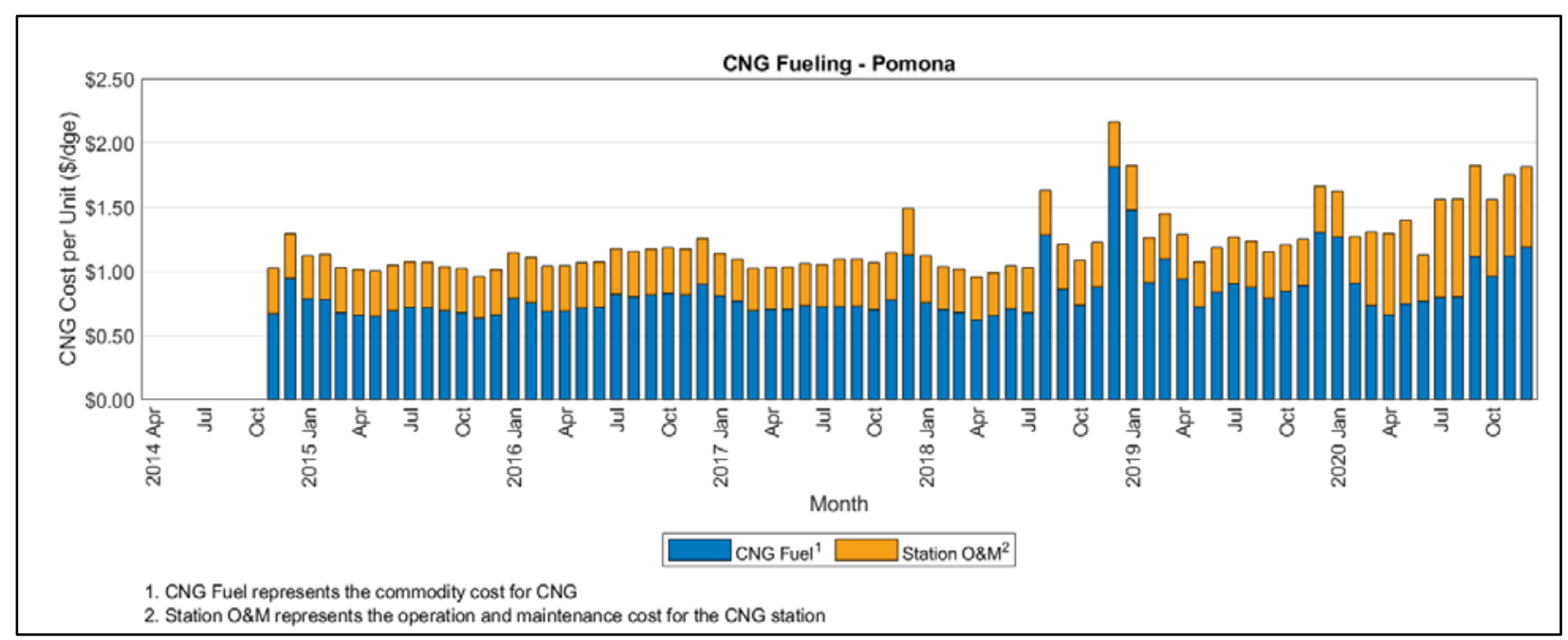

Figure 25. Monthly average CNG price for Pomona

Monthly average price for electricity and CNG fuel are compared on a diesel-equivalent basis in Figure 26. Electricity is 5-6.5 times more expensive than CNG fuel, depending on the season. Combining the unit cost of fuel with the fuel economy for each fleet produces the average fuel cost per mile, which is compared in Figure 27. The fuel economy benefit of the more efficient BEB fleet is largely offset by the higher cost of electricity relative to CNG fuel, resulting in a higher fuel cost per mile for the BEBs. Increasing CNG costs in 2019 and 2020 bring the recent fuel cost per mile for the CNG fleet close to the winter average fuel cost per mile for the BEB fleet. During summer months, the BEBs have lower fuel economy and higher electricity prices, resulting in a large seasonal variation in fuel cost per mile. Overall, the BEB fleet averaged $\$ 0.45$ per mile and the CNG fleet averaged $\$ 0.28$ per mile during the evaluation.

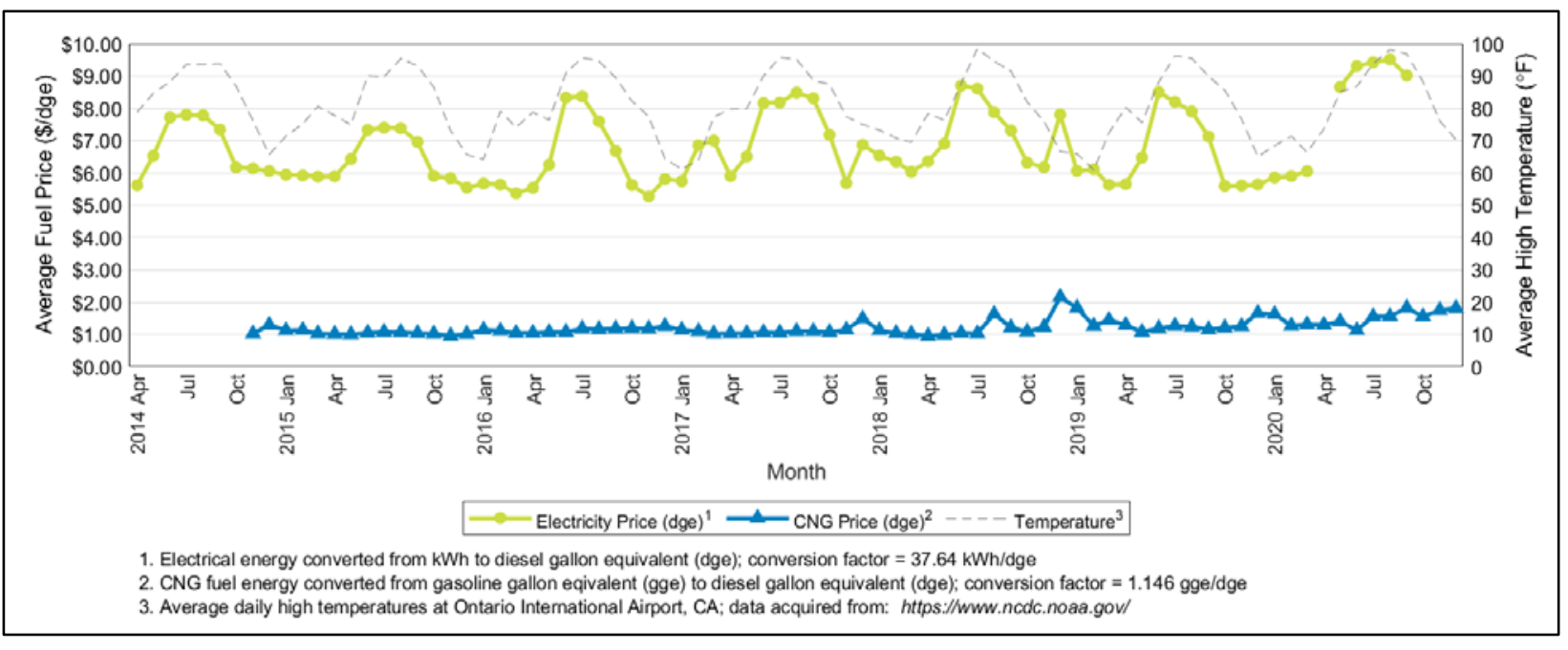

Figure 26. Monthly average fuel price for the BEB and CNG fleets 


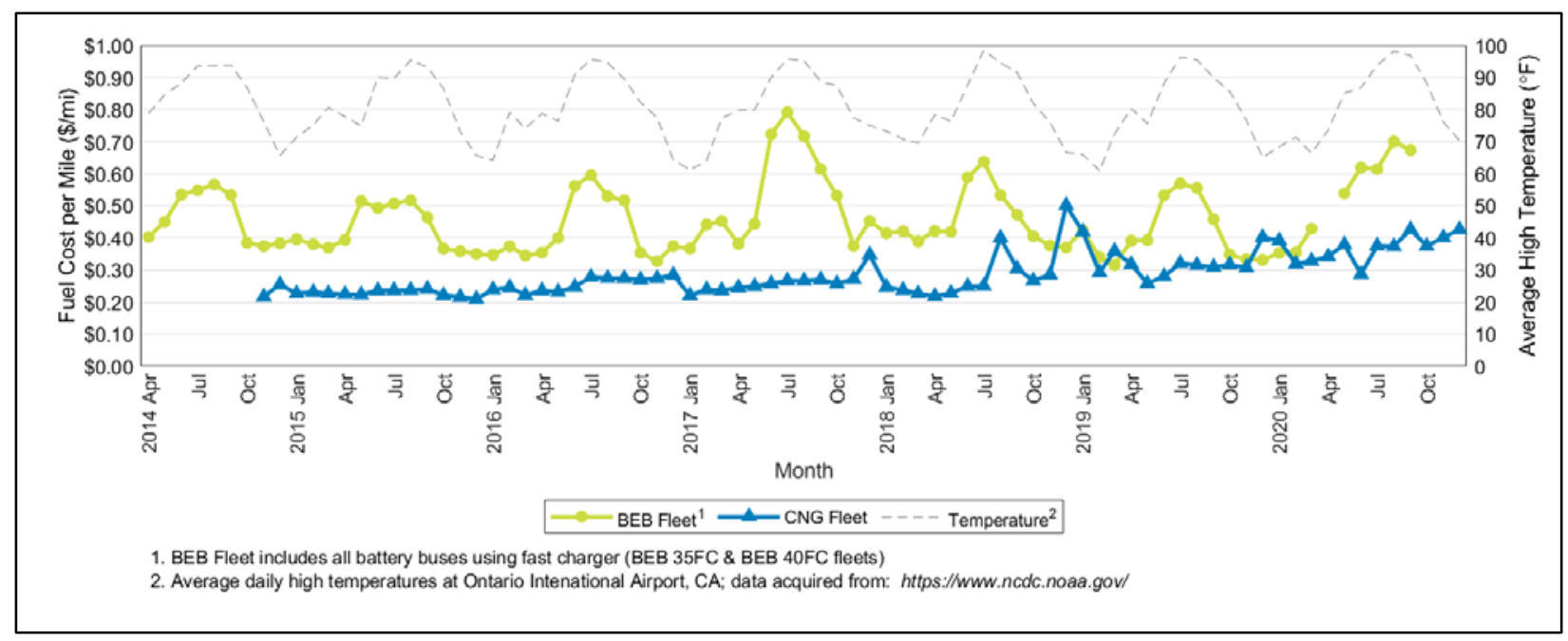

Figure 27. Monthly average energy cost per mile for the BEB and CNG fleets

\subsection{Roadcall Analysis}

A roadcall or revenue vehicle system failure (as named in the National Transit Database ${ }^{8}$ ) is defined as a failure of an in-service bus that causes the bus to be replaced on route or causes a significant delay in schedule. If the problem with the bus can be repaired during a layover and the schedule is kept, this is not considered a roadcall. The analysis described here includes only roadcalls that were caused by "chargeable" failures. Chargeable roadcalls include systems that can physically disable the bus from operating on route, such as interlocks (doors, air system), engine, or things that are deemed to be safety issues if operation of the bus continues. They do not include roadcalls for things such as problems with radios, fareboxes, or destination signs.

The transit industry measures reliability as mean distance between failures, also documented as miles between roadcalls (MBRC). Table 11 provides the MBRC for the BEBs and CNG buses categorized by general bus roadcalls, propulsion-related roadcalls, and ESS-related roadcalls. Propulsion-related roadcalls include all roadcalls due to propulsion-related systems, including the battery system (or engine for a conventional bus), electric drive, fuel, exhaust, air intake, cooling, non-lighting electrical, and transmission systems. The ESS-related roadcalls and MBRC are included for the BEBs. This roadcall analysis includes data accumulated since the clean point of April 2014.

\footnotetext{
${ }^{8} \mathrm{https}: / / \mathrm{www}$. transit.dot.gov/ntd
} 
Table 11. Roadcalls and MBRC for BEB and CNG Fleets

\begin{tabular}{|l|c|c|c|}
\hline \multicolumn{1}{|c}{} & BEB 35FC & BEB 40FC & CNG \\
\hline Dates & $4 / 2014-12 / 2020$ & $1 / 2017-12 / 2020$ & $10 / 2014-12 / 2020$ \\
\hline Total miles accumulated & $1,772,084$ & 153,005 & $2,763,746$ \\
\hline Average miles accumulated per bus & 147,674 & 76,503 & 345,468 \\
\hline Bus roadcalls & 312 & 19 & 110 \\
\hline Bus MBRC & 5,680 & 8,053 & 25,125 \\
\hline Propulsion-related roadcalls & 132 & 9 & 73 \\
\hline Propulsion-related MBRC & 13,425 & 17,001 & 37,860 \\
\hline ESS-related roadcalls & 9 & 1 & - \\
\hline ESS-related MBRC & 196,898 & 153,005 & - \\
\hline
\end{tabular}

Figure 28 presents the cumulative MBRC by category for the BEB and CNG fleets. The upper chart tracks the total bus MBRC for all chargeable roadcalls. DOE and the Federal Transit Administration have not established performance targets specific to BEBs, but the MBRC targets established for $\mathrm{FCEBs}^{9}$ were based on typical conventional buses, and the targets could be considered appropriate for any advanced technology. The ultimate target for total bus MBRC $(4,000)$ is included in the upper plot of Figure 28 as a red dashed line. The total bus MBRC for each BEB fleet is lower than that of the CNG fleet but has surpassed the ultimate target. The lower chart tracks the propulsion-related MBRC for each fleet.

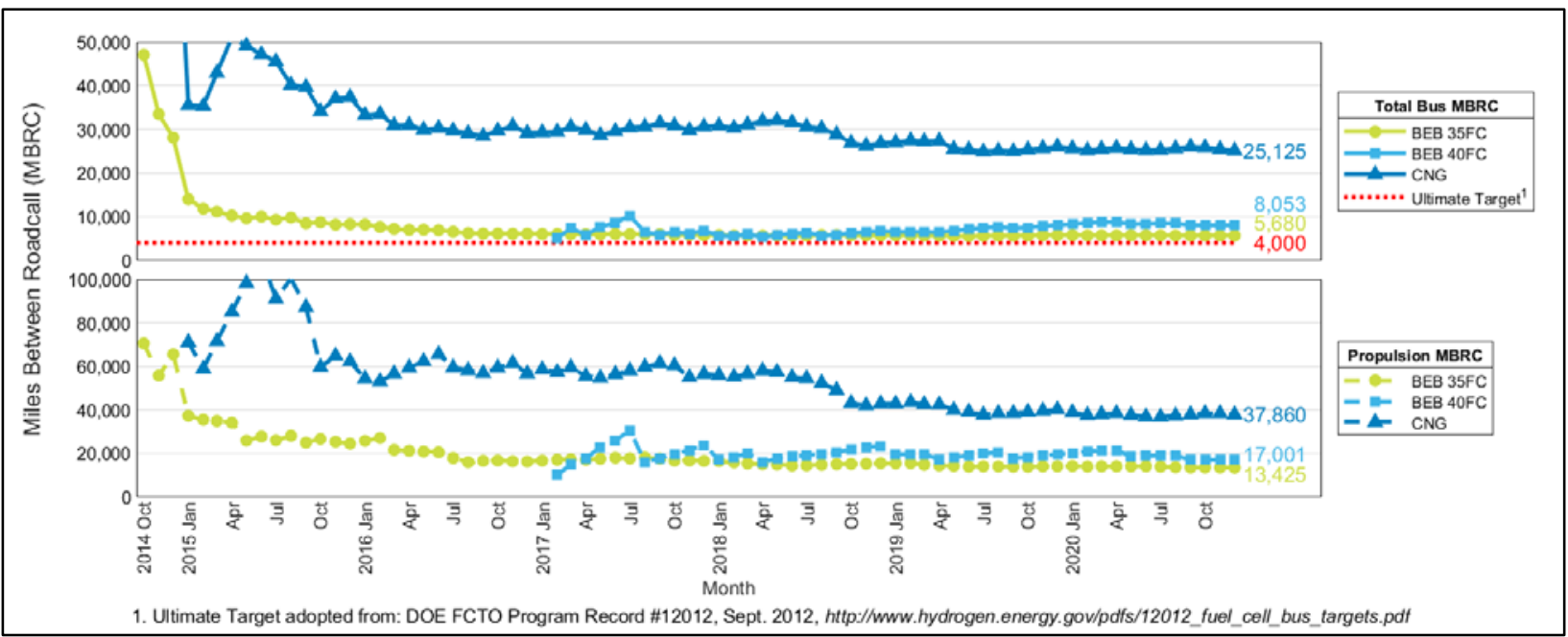

Figure 28. Cumulative MBRC for the BEB and CNG fleets

\subsection{Maintenance Analysis}

NREL collected all work orders for the BEB and CNG buses for this evaluation. Costs for accident-related repair, which are extremely variable from bus to bus, were eliminated from the analysis for all three bus fleets. Warranty costs were also removed from the cost-per-mile

\footnotetext{
9 “Fuel Cell Bus Targets," Fuel Cell Technologies Program Record \# 12012, Sept. 2012, www.hydrogen.energy.gov/pdfs/12012 fuel_cell_bus targets.pdf.
} 
calculations because those costs are covered in the capital cost of the buses. For consistency, NREL uses a constant maintenance labor rate of $\$ 50$ per hour; this does not reflect an average rate for Foothill Transit. This section first covers total maintenance costs and then maintenance costs by bus system.

At the beginning of the project, Proterra technicians performed all maintenance on the BEBs. In January 2015, the Foothill Transit contractor staff took over the preventive maintenance inspection (PMI) and general bus work. In mid-2017, most maintenance work was transitioned to Foothill Transit contractor staff, who request assistance from Proterra as needed. All three fleets have now surpassed the end of the warranty period for most components.

\subsubsection{Total Work Order Maintenance Costs}

Total maintenance costs include the price of parts and labor rates at $\$ 50$ per hour. Cost per mile is calculated as follows:

Cost per mile $=[($ labor hours $\times 50)+$ parts cost $] /$ mileage

Table 12 shows total maintenance costs for the two BEB fleets and CNG baseline fleet since the beginning of the evaluation period. Scheduled and unscheduled maintenance cost per mile is provided for each bus and fleet of buses. When compared to the baseline CNG fleet, the BEB $35 \mathrm{FC}$ buses and BEB 40FC buses had a maintenance cost per mile that was $56 \%$ and $75 \%$ higher, respectively.

Table 12. Total Work Order Maintenance Costs, BEB Fleets

\begin{tabular}{|c|c|c|c|c|c|c|}
\hline Bus ID & Miles & $\begin{array}{l}\text { Parts Cost } \\
\text { (\$) }\end{array}$ & $\begin{array}{l}\text { Labor } \\
\text { Hours }\end{array}$ & $\begin{array}{l}\text { Scheduled } \\
\text { Cost per } \\
\text { Mile (\$) }\end{array}$ & $\begin{array}{l}\text { Unscheduled } \\
\text { Cost per Mile } \\
\text { (\$) }\end{array}$ & $\begin{array}{l}\text { Total Cost } \\
\text { per Mile (\$) }\end{array}$ \\
\hline 2004 & 119,121 & $42,252.22$ & 553.3 & 0.08 & 0.51 & 0.59 \\
\hline 2005 & 136,406 & $28,181.32$ & 622.3 & 0.07 & 0.36 & 0.43 \\
\hline 2006 & 133,939 & $37,258.55$ & 871.6 & 0.08 & 0.52 & 0.60 \\
\hline 2007 & 135,606 & $23,694.96$ & 783.0 & 0.07 & 0.39 & 0.46 \\
\hline 2008 & 132,585 & $45,431.19$ & 773.6 & 0.07 & 0.56 & 0.63 \\
\hline 2009 & 145,524 & $35,769.95$ & 739.2 & 0.07 & 0.43 & 0.50 \\
\hline 2010 & 132,445 & $27,786.37$ & 642.4 & 0.07 & 0.38 & 0.45 \\
\hline 2011 & 131,787 & $27,348.24$ & 550.2 & 0.08 & 0.34 & 0.42 \\
\hline 2012 & 131,233 & $29,690.72$ & 608.6 & 0.07 & 0.39 & 0.46 \\
\hline 2013 & 108,337 & $18,852.89$ & 680.7 & 0.08 & 0.41 & 0.49 \\
\hline 2014 & 145,999 & $23,707.82$ & 615.3 & 0.07 & 0.30 & 0.37 \\
\hline 2015 & 122,523 & $41,542.08$ & 687.2 & 0.07 & 0.55 & 0.62 \\
\hline $\begin{array}{c}\text { BEB 35FC } \\
\text { Fleet }\end{array}$ & $1,575,505$ & $381,516.31$ & $8,127.5$ & 0.07 & 0.43 & 0.50 \\
\hline 2016 & 70,885 & $18,006.37$ & 568.8 & 0.07 & 0.58 & 0.66 \\
\hline 2017 & 82,120 & $16,791.27$ & 460.7 & 0.07 & 0.42 & 0.49 \\
\hline $\begin{array}{l}\text { BEB 40FC } \\
\text { Fleet }\end{array}$ & 153,005 & $34,797.64$ & 1029.5 & 0.07 & 0.49 & 0.56 \\
\hline
\end{tabular}


Table 13. Total Work Order Maintenance Costs, CNG Fleet

\begin{tabular}{|c|c|c|c|c|c|c|}
\hline Bus ID & Miles & $\begin{array}{c}\text { Parts Cost } \\
\mathbf{( \$ )}\end{array}$ & $\begin{array}{c}\text { Labor } \\
\text { Hours }\end{array}$ & $\begin{array}{c}\text { Scheduled } \\
\text { Cost per } \\
\text { Mile } \mathbf{( \$ )}\end{array}$ & $\begin{array}{c}\text { Unscheduled } \\
\text { Cost per Mile } \\
\mathbf{( \$ )}\end{array}$ & $\begin{array}{c}\text { Total } \\
\text { Cost per } \\
\text { Mile (\$) }\end{array}$ \\
\hline 2200 & 348,085 & $54,119.46$ & 954.1 & 0.11 & 0.18 & 0.29 \\
\hline 2201 & 322,333 & $63,491.78$ & $1,147.6$ & 0.12 & 0.25 & 0.37 \\
\hline 2202 & 350,310 & $50,915.21$ & 942.4 & 0.12 & 0.16 & 0.28 \\
\hline 2203 & 348,350 & $67,744.43$ & $1,045.9$ & 0.12 & 0.23 & 0.34 \\
\hline 2204 & 331,246 & $65,350.23$ & $1,125.2$ & 0.11 & 0.25 & 0.37 \\
\hline 2205 & 351,153 & $57,399.85$ & $1,007.5$ & 0.11 & 0.20 & 0.31 \\
\hline 2206 & 356,190 & $52,267.29$ & $1,020.1$ & 0.12 & 0.17 & 0.29 \\
\hline 2207 & 356,079 & $61,893.17$ & 969.3 & 0.10 & 0.21 & 0.31 \\
\hline CNG Fleet & $\mathbf{2 , 7 6 3 , 7 4 6}$ & $\mathbf{4 7 3 , 1 8 1 . 4 0}$ & $\mathbf{8 , 2 1 2 . 1}$ & $\mathbf{0 . 1 1}$ & $\mathbf{0 . 2 1}$ & $\mathbf{0 . 3 2}$ \\
\hline
\end{tabular}

Figure 29 presents the cumulative maintenance cost for all three fleets since the start of operation. Costs for the BEB 35FC and CNG fleets are low in the first 2 years when both are under full warranty. After reaching the end of the warranty period, the CNG fleet shows a steady upward trend as the buses age. This is the typical pattern for conventional technology buses. The cost trend for the BEB 35FC fleet begins a steeper increase in mid-2017. At that time, operation and maintenance at the Pomona facility was transferred to a new contractor. In addition, the contractor staff took over all maintenance of the fleet. Prior to that time, OEM technicians were on-site to handle many of the advanced technology troubleshooting and repair. Added labor hours for training on the advanced technology was one factor in the higher cost. Another factor was that the agency had to cover most parts costs once the warranty period ended. Some of the advanced technology parts were expensive, such as DC-DC converters and motors.

Cumulative cost for the BEB 40FC fleet was more variable. Because the fleet consists of only two buses, cost-per-mile calculations are more sensitive to changes in costs and mileage. Lower mileage accumulation for one bus can have a significant effect on the cost per mile, even if the total costs are low.

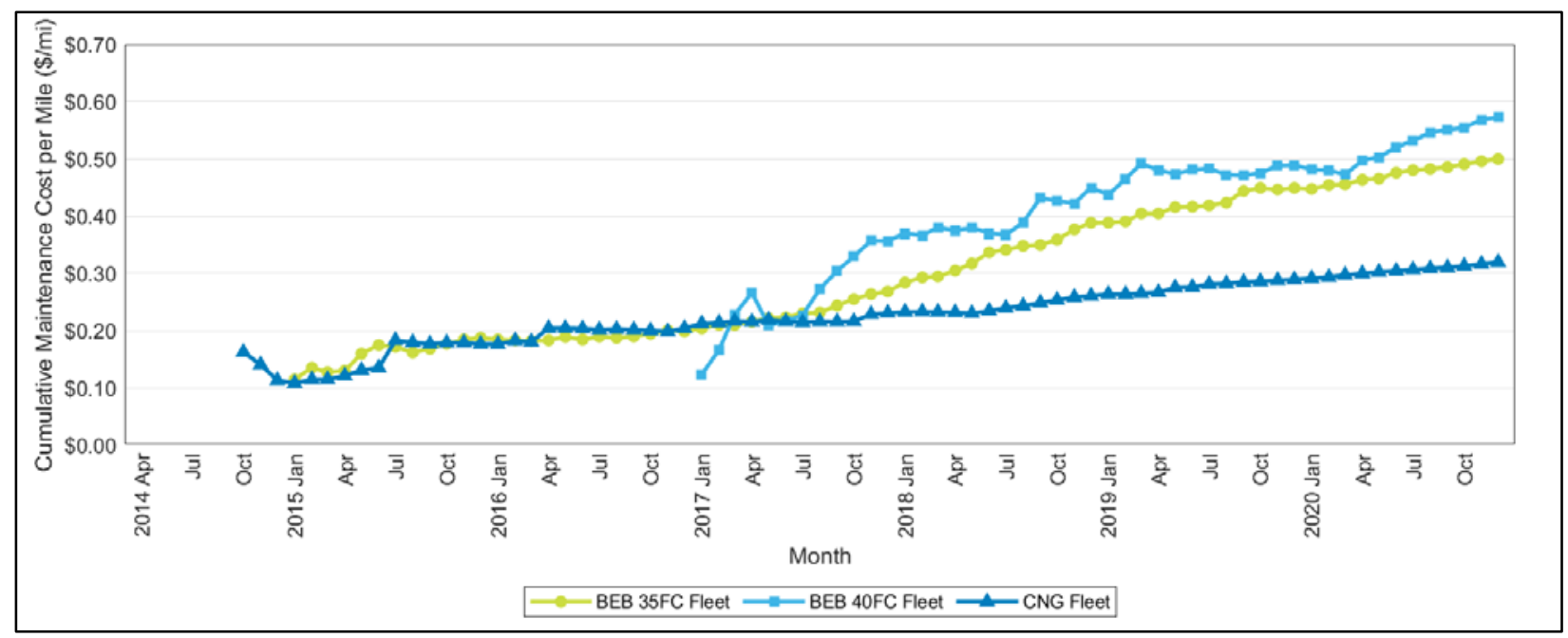

Figure 29. Cumulative maintenance costs per mile for the BEB and CNG fleets 


\subsubsection{Monthly Maintenance Cost Comparison}

This section presents the monthly maintenance cost for each fleet for the entire data period. To understand what factors are driving costs, NREL analyses the data multiple ways. Figure 30 shows the monthly total cost per mile for each of the three fleets. After the warranty period, costs for the BEB 35FC and BEB 40FC fleets are highly variable from month to month when highcost parts, increased labor hours, and low mileage all have an effect on the cost per mile for a specific month. In the first half of 2020, these effects were compounded by reduced service due to the COVID-19 pandemic. Later that year, an accident with the fast charger resulted in all the buses being removed from service. Transit technicians completed maintenance work during this time, but few miles were accumulated on the buses. This results in spikes in monthly cost per mile that are too high for the chart scale. Those months are excluded from the figures because they are not representative of the overall costs. The data are included in the analysis totals.

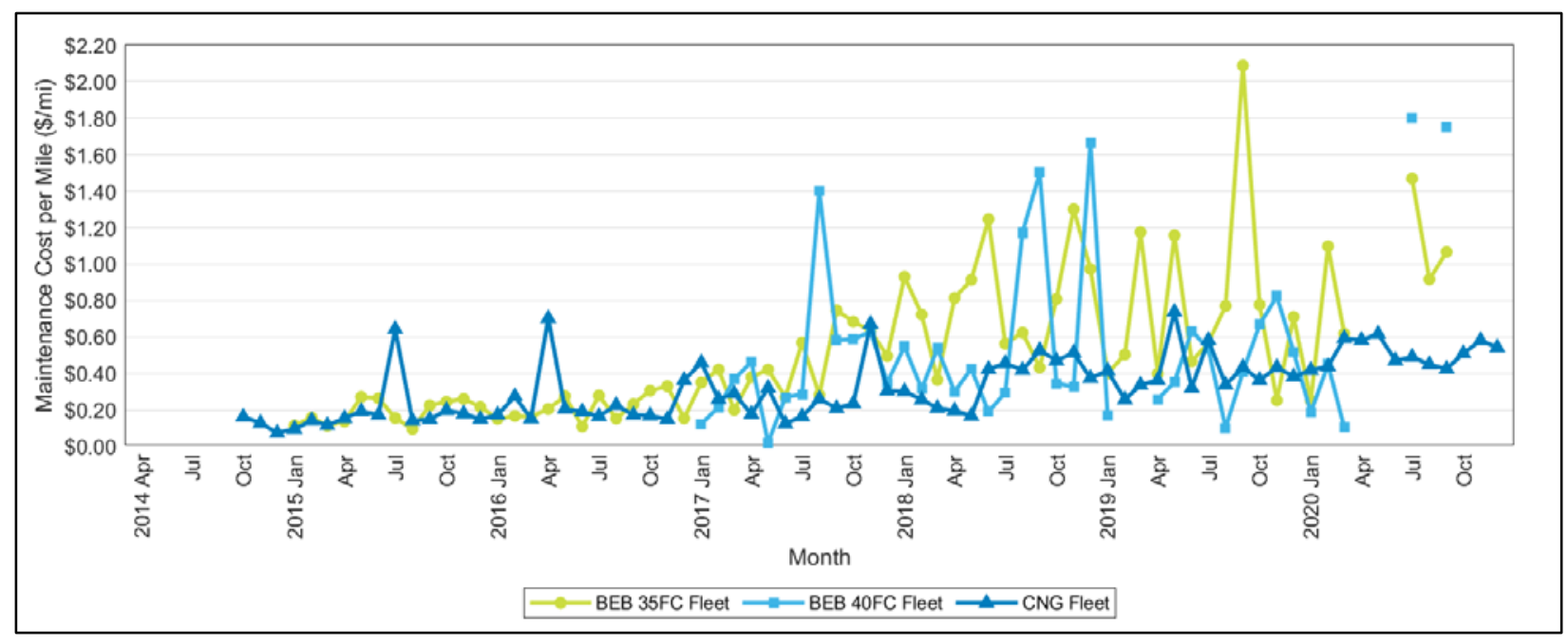

Figure 30. Monthly maintenance costs per mile for the BEB and CNG fleets

The monthly scheduled and unscheduled maintenance cost per mile for the BEB 35FC, BEB 40FC, and CNG buses are shown as stacked columns in Figure 31, Figure 32, and Figure 33, respectively. Scheduled maintenance for all three fleets was consistent over the data period. The CNG buses typically have higher scheduled maintenance costs per mile than the BEBs and lower unscheduled costs per mile. Spikes in cost for the CNG buses typically occur when several buses reach the mileage target for a major PMI in the same month. Unscheduled costs for the CNG fleet increase over time as the buses age and require major repair or tune-ups. The higher unscheduled maintenance costs for the BEBs occur in the latter half of the evaluation period once the warranty ended and parts costs became the transit agency's responsibility. 


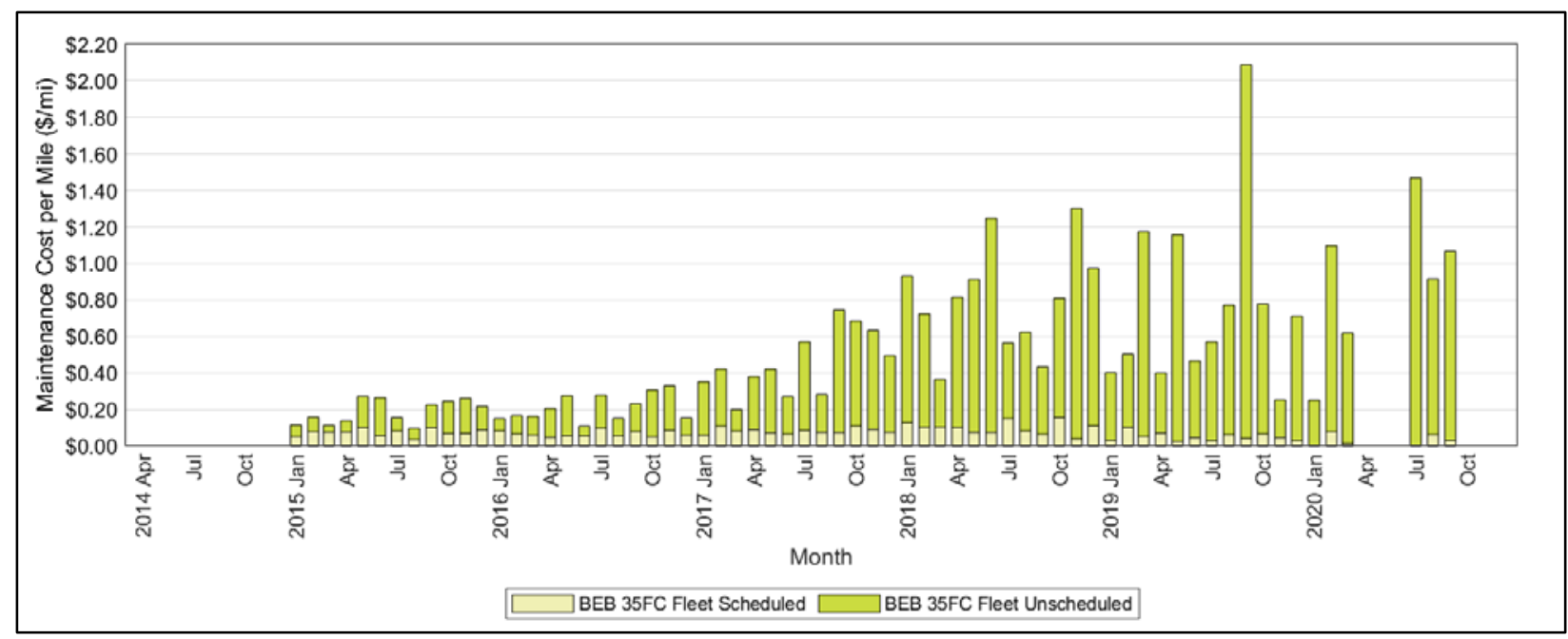

Figure 31. Monthly scheduled and unscheduled maintenance costs per mile for the BEB 35FC fleet

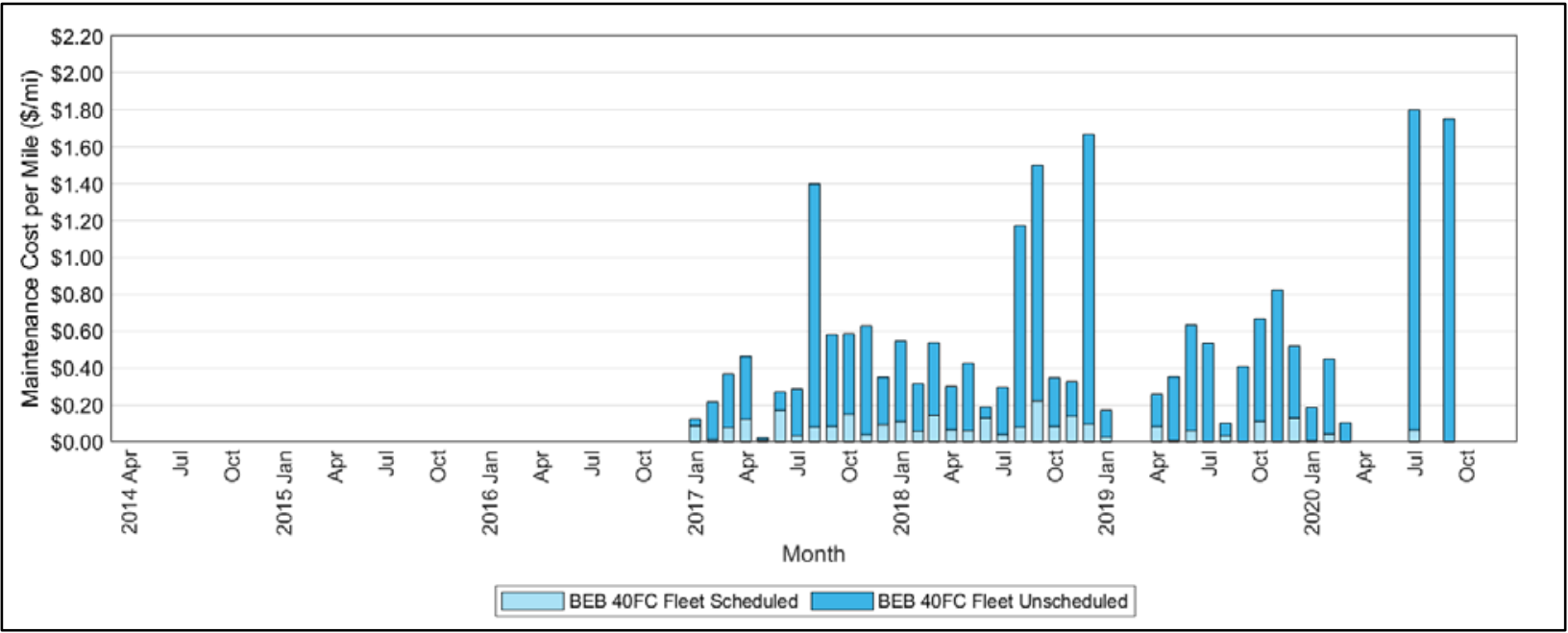

Figure 32. Monthly scheduled and unscheduled maintenance costs per mile for the BEB 40FC fleet

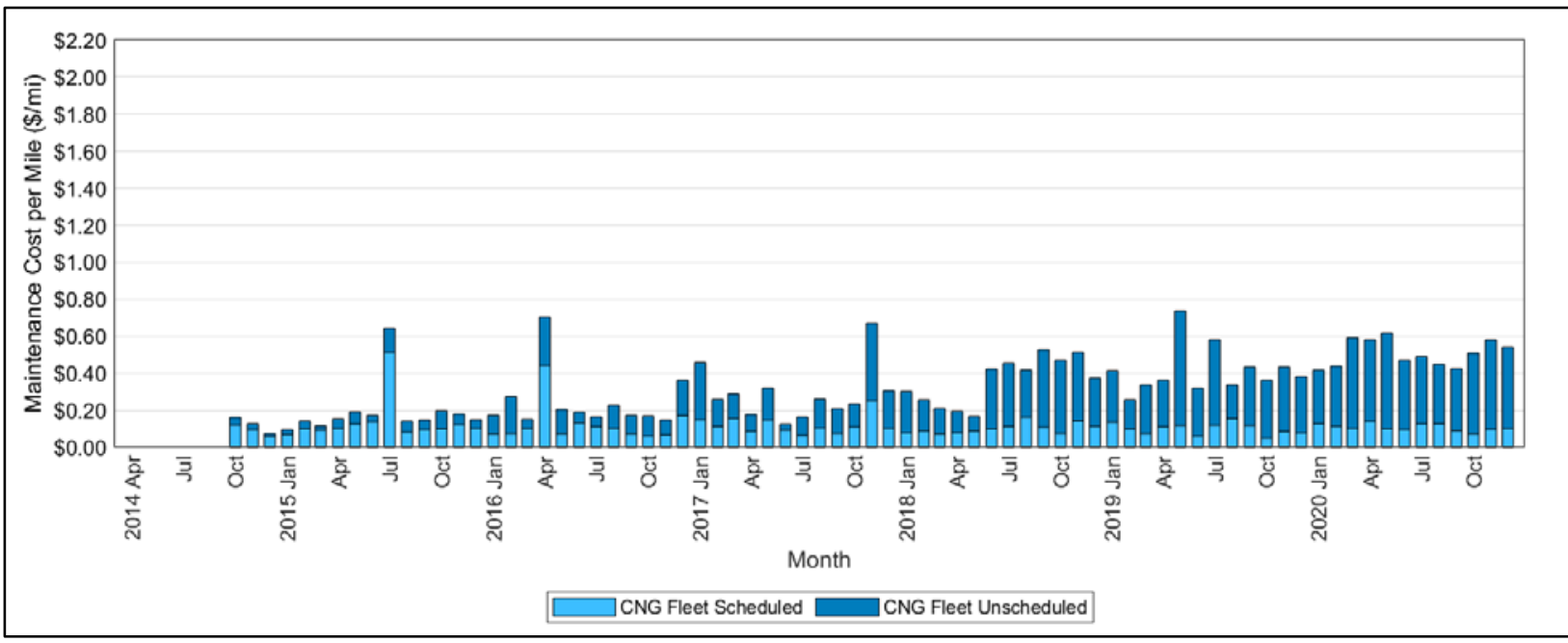

Figure 33. Monthly scheduled and unscheduled maintenance costs per mile for the CNG fleet 
To better understand what is driving costs, Figure 34, Figure 35, and Figure 36 present the same data for the three fleets, separated by parts and labor cost per mile. Although the parts costs for the BEB fleets appear high, the biggest percent of cost was for labor hours to troubleshoot and repair issues. For the BEB 35FC buses, the labor cost made up 52\% of the total cost. For the BEB $40 \mathrm{FC}$ fleet, labor cost made up $60 \%$ of the total cost. For the CNG buses, $46 \%$ of the total cost was for labor.

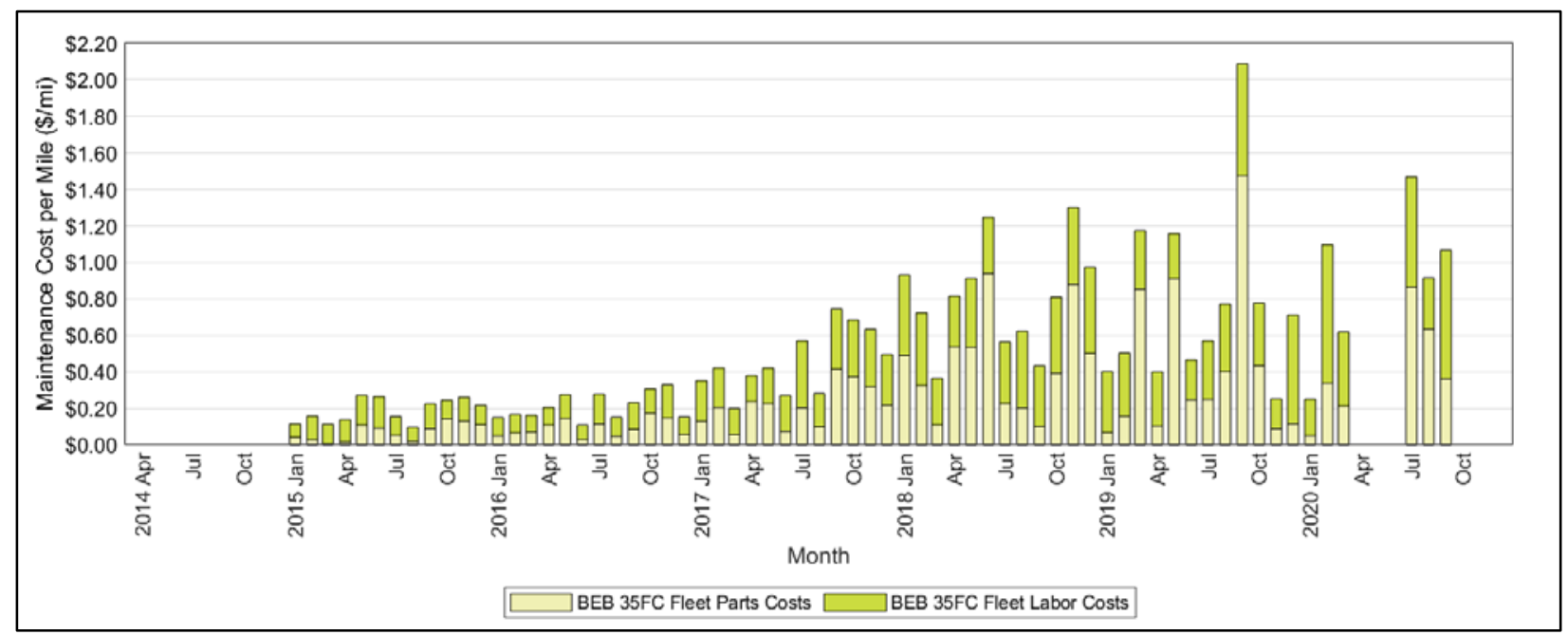

Figure 34. Monthly parts and labor maintenance costs per mile for the BEB 35FC fleet

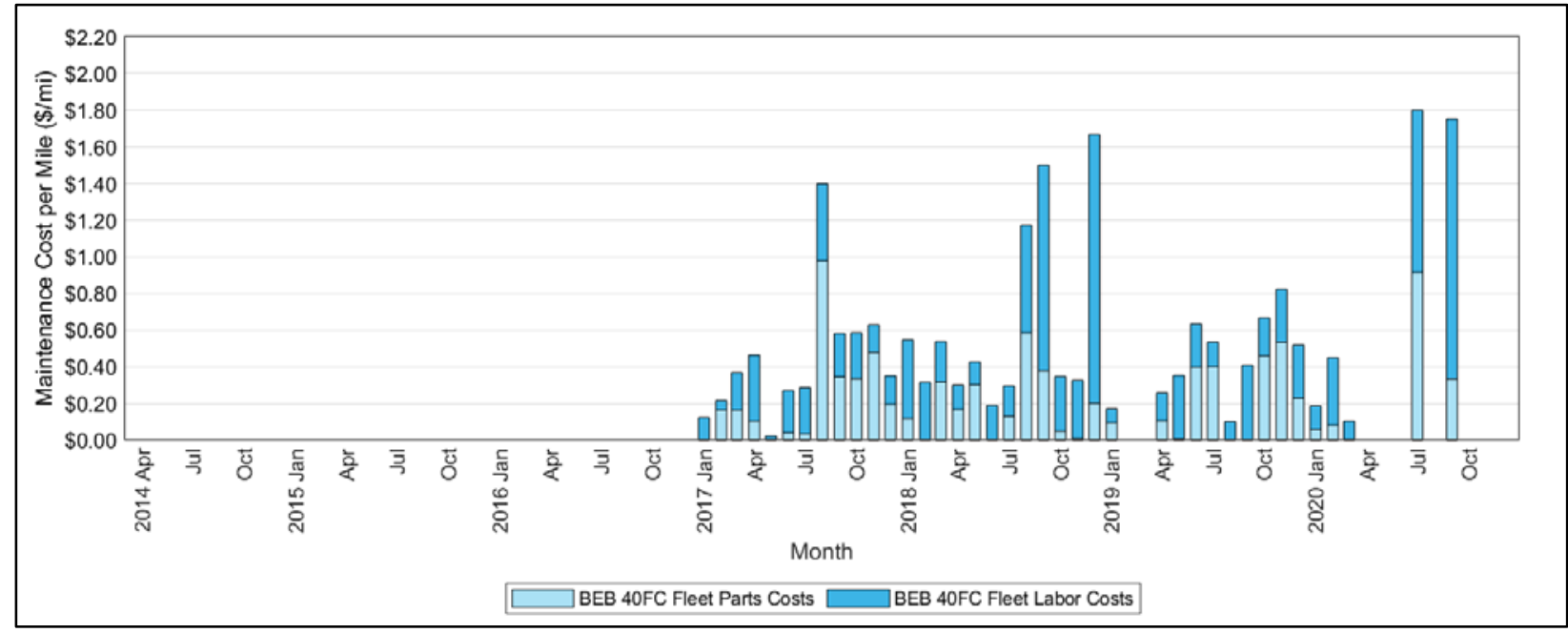

Figure 35. Monthly parts and labor maintenance costs per mile for the BEB 40FC fleet 


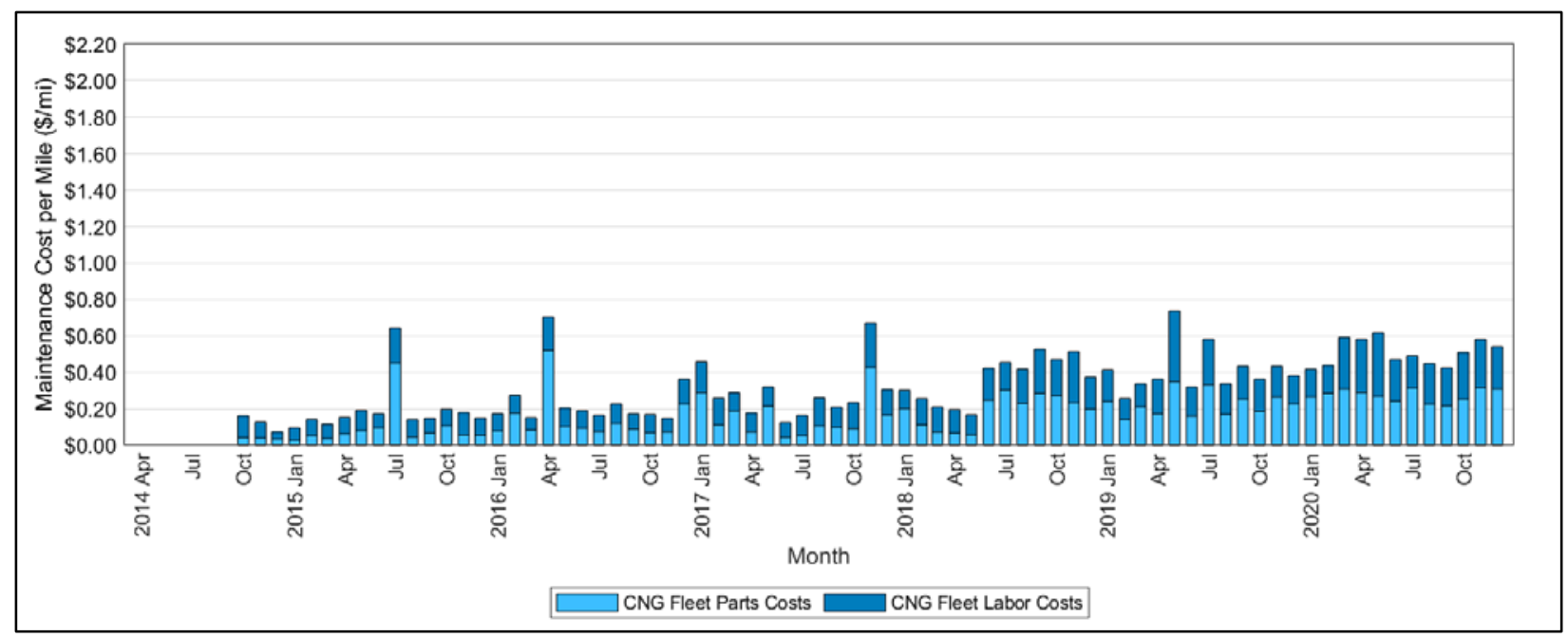

Figure 36. Monthly parts and labor maintenance costs per mile for the CNG fleet

\subsubsection{Work Order Maintenance Costs Categorized by System}

Table 14 shows maintenance costs by vehicle system for each fleet (without warranty costs). The vehicle systems shown in the table are as follows:

- Cab, body, and accessories: Includes body, glass, cab and sheet metal, seats and doors, and accessory repairs such as hubodometers and radios

- Propulsion-related systems: Repairs for exhaust, fuel, engine, electric motors, battery modules, propulsion control, non-lighting electrical (charging, cranking, and ignition), air intake, cooling, and transmission

- PMI: Labor for inspections during preventive maintenance

- Brakes: Includes brake pads, disks, calipers, anti-lock braking system, and brake chambers

- Frame, steering, and suspension

- Heating, ventilation, and air conditioning (HVAC)

- Lighting

- Air system, general

- Axles, wheels, and drive shaft

- Tires

- Towing charges. 
Table 14. Maintenance Cost per Mile by Vehicle System

\begin{tabular}{|c|c|c|c|c|c|c|}
\hline \multirow[b]{2}{*}{ Vehicle System } & \multicolumn{2}{|c|}{ BEB 35FC Fleet } & \multicolumn{2}{|c|}{ BEB 40FC Fleet } & \multicolumn{2}{|c|}{ CNG Fleet } \\
\hline & $\begin{array}{l}\text { Cost per } \\
\text { Mile } \\
\text { (\$) }\end{array}$ & $\begin{array}{c}\text { Percent } \\
\text { of Total } \\
(\%)\end{array}$ & $\begin{array}{c}\text { Cost } \\
\text { per Mile } \\
(\$)\end{array}$ & $\begin{array}{c}\text { Percent } \\
\text { of Total } \\
(\%)\end{array}$ & $\begin{array}{l}\text { Cost per } \\
\text { Mile } \\
\text { (\$) }\end{array}$ & $\begin{array}{c}\text { Percent } \\
\text { of Total } \\
(\%)\end{array}$ \\
\hline Propulsion-related & 0.182 & 36.4 & 0.225 & 39.9 & 0.133 & 41.5 \\
\hline Cab, body, and accessories & 0.077 & 15.4 & 0.112 & 19.8 & 0.052 & 16.1 \\
\hline PMI & 0.071 & 14.2 & 0.063 & 11.1 & 0.052 & 16.2 \\
\hline Brakes & 0.012 & 2.4 & 0.005 & 0.8 & 0.018 & 5.7 \\
\hline Frame, steering, and suspension & 0.014 & 2.8 & 0.003 & 0.6 & 0.007 & 2.2 \\
\hline HVAC & 0.016 & 3.2 & 0.009 & 1.6 & 0.009 & 3.0 \\
\hline Lighting & 0.012 & 2.5 & 0.011 & 1.9 & 0.003 & 0.8 \\
\hline Air, general & 0.002 & 0.4 & 0.053 & 9.3 & 0.012 & 3.7 \\
\hline Axles, wheels, and drive shaft & 0.036 & 7.3 & 0.009 & 1.5 & 0.004 & 1.2 \\
\hline Tires & 0.073 & 14.6 & 0.074 & 13.1 & 0.030 & 9.3 \\
\hline Towing charges & 0.004 & 0.8 & 0.002 & 0.3 & 0.001 & 0.3 \\
\hline Total & 0.500 & 100 & 0.564 & 100 & 0.320 & 100 \\
\hline
\end{tabular}

The color shading denotes the systems with the highest percentage of maintenance costs: orange for the highest, green for the second highest, and purple for the third highest. The systems with the highest percentage of maintenance costs for the BEB 35FC and BEB 40FC fleets were the same: (1) propulsion-related; (2) cab, body, and accessories; and (3) tires. For the CNG buses the three systems with the highest percentage of maintenance costs were (1) propulsion-related; (2) PMI; and (3) cab, body, and accessories. Figure 37 shows the monthly maintenance cost per mile by system for the BEB 35FC fleet and Figure 38 shows the cost per mile by system for the BEB 40FC fleet. Figure 39 presents the same data for the CNG buses. As mentioned previously, months with abnormally high costs were removed from the charts but are included in the analysis and tables. Both BEB fleets experienced issues with premature failure of the low-voltage batteries. These issues contribute to the high cost for the propulsion system. Tire replacement and repair also resulted in higher costs for the BEB fleets. The issues of tire wear and failure of low-voltage batteries are explained in more detail in Section 4.6.5.

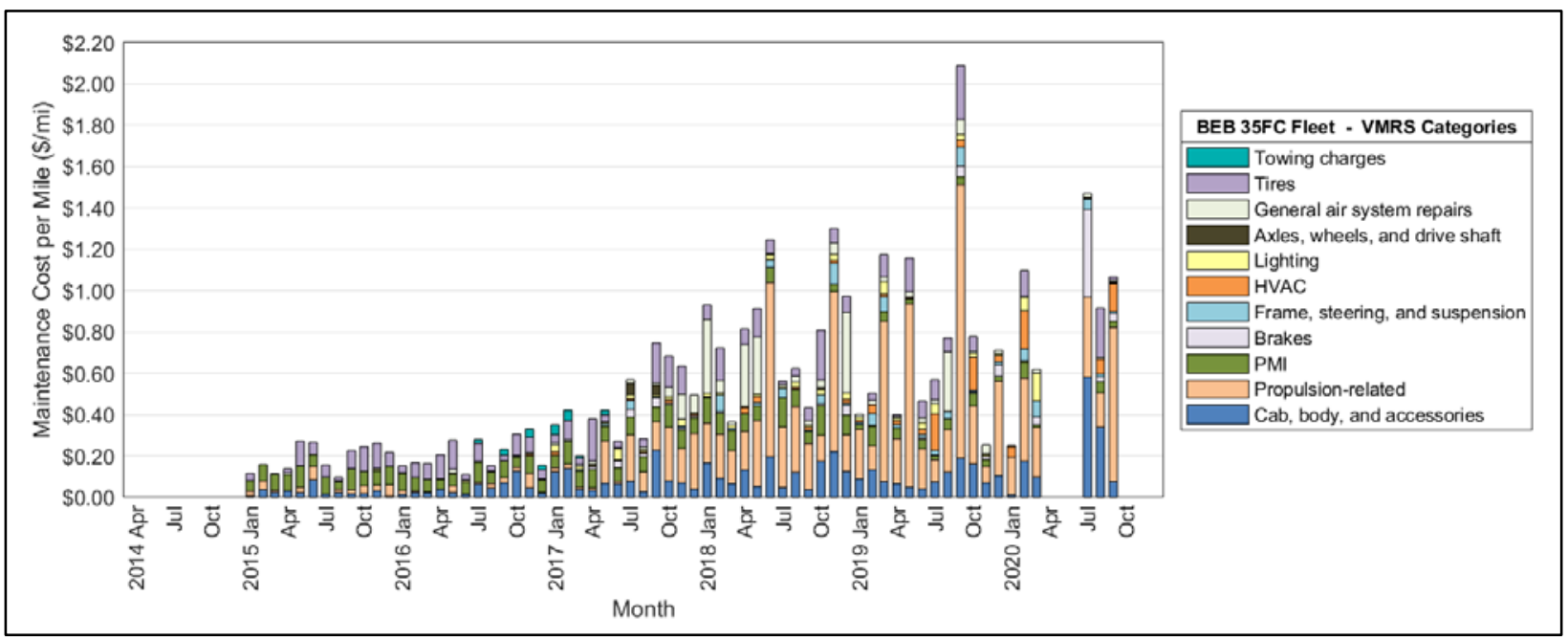

Figure 37. Monthly maintenance cost per mile by vehicle system for the BEB 35FC fleet 


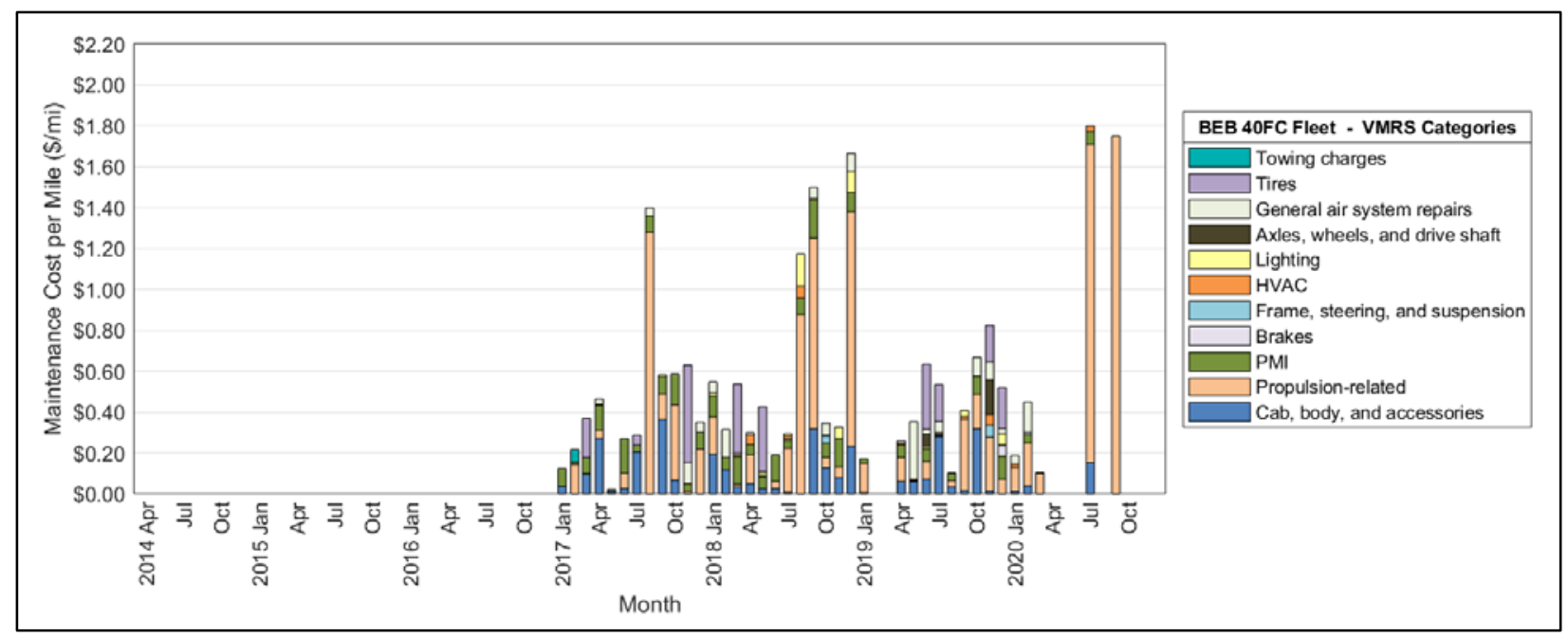

Figure 38. Monthly maintenance cost per mile by vehicle system for the BEB 40FC fleet

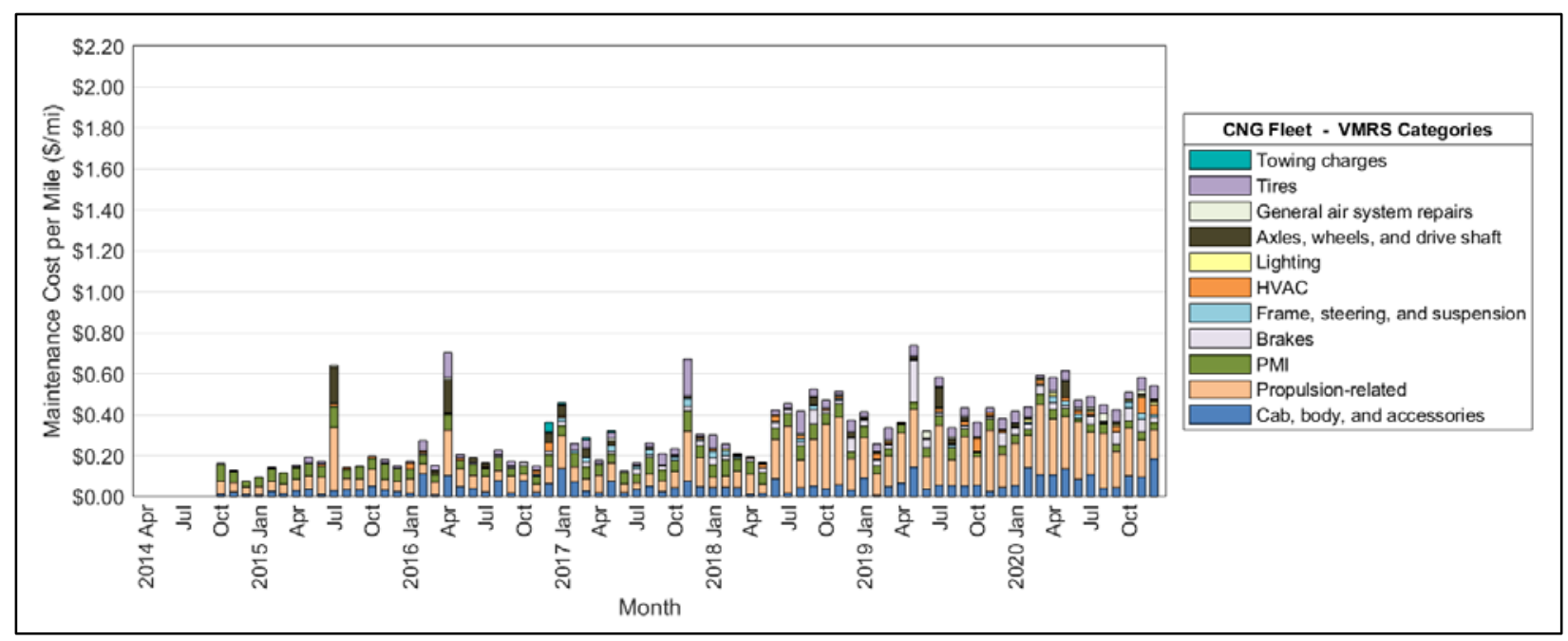

Figure 39. Monthly maintenance cost per mile by vehicle system for the CNG fleet

\subsubsection{Propulsion-Related Work Order Maintenance Costs}

Propulsion-related vehicle systems include the exhaust, fuel, engine, battery modules, electric propulsion, air intake, cooling, non-lighting electrical, and transmission systems. These vehicle subsystems have been separated to highlight how maintenance costs for the propulsion system are affected by the change from conventional technology (CNG engine) to advanced technology (batteries and electric drive system).

Table 15 shows the propulsion-related system maintenance by category. The propulsion-related maintenance costs for the BEB 35FC buses were 37\% higher than that of the CNG buses. For the BEB 40FC buses, the propulsion-related costs were $70 \%$ higher than that of the CNG fleet. Parts for scheduled maintenance, such as filters and fluids, are included in the specific system categories. For example, oil and oil filters are included in the power plant subsystem parts costs, whereas air filters are included in the air intake subsystem parts costs. Cost of low-voltage batteries, which are included in the non-lighting electrical system, was the primary factor in the 
higher cost for that system. High-dollar parts and extensive labor for troubleshooting issues resulted in high costs for the electric drive and motor system subsystem.

Table 15. Propulsion-Related Work Order Maintenance Costs by Subsystem $(\$ / \mathrm{mi})$

\begin{tabular}{|l|c|c|c|}
\hline \multicolumn{1}{|c}{ Propulsion Subsystem } & BEB 35FC & BEB 40FC & CNG \\
\hline Exhaust system & 0.000 & 0.000 & 0.010 \\
\hline Fuel system & 0.000 & 0.000 & 0.006 \\
\hline Power plant system (battery or CNG engine) & 0.008 & 0.004 & 0.040 \\
\hline Electric drive and motor system & 0.066 & 0.071 & 0.000 \\
\hline $\begin{array}{l}\text { Non-lighting electrical system (general electrical, } \\
\text { charging, cranking, ignition) }\end{array}$ & 0.085 & 0.136 & 0.037 \\
\hline Air intake system & 0.000 & 0.000 & 0.009 \\
\hline Cooling system & 0.006 & 0.008 & 0.022 \\
\hline Transmission system & 0.016 & 0.005 & 0.009 \\
\hline Hydraulic system & 0.000 & 0.000 & 0.000 \\
\hline Total propulsion-related system maintenance & 0.182 & 0.225 & 0.133 \\
\hline
\end{tabular}

Figure 40, Figure 41, and Figure 42 show the monthly cost per mile by propulsion subsystem for each fleet. High costs for the low-voltage batteries show up in the cranking/charging category. The high costs for the electric drive category are due to expensive parts and higher labor hours for troubleshooting and repair on components such as drive motors and DC-DC converters.

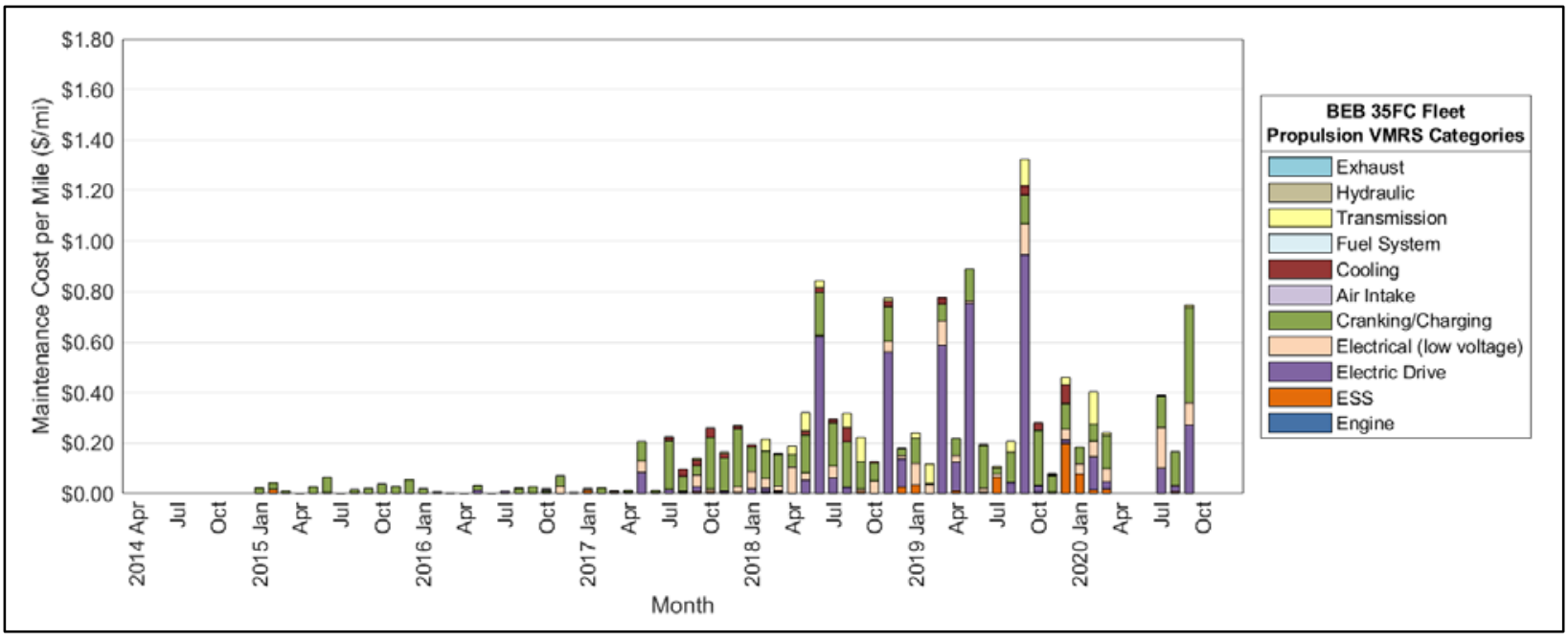

Figure 40. Monthly maintenance cost per mile by propulsion subsystem for the BEB 35FC fleet 


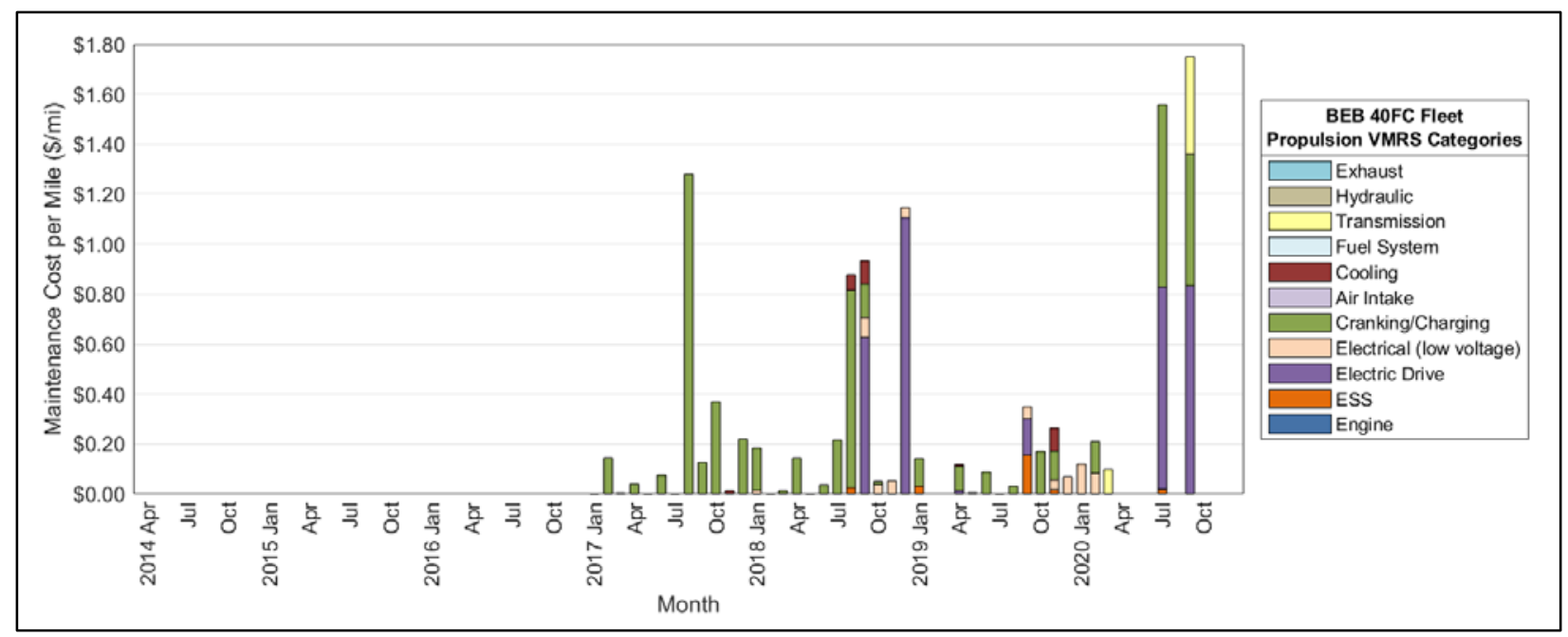

Figure 41. Monthly maintenance cost per mile by propulsion subsystem for the BEB 40FC fleet

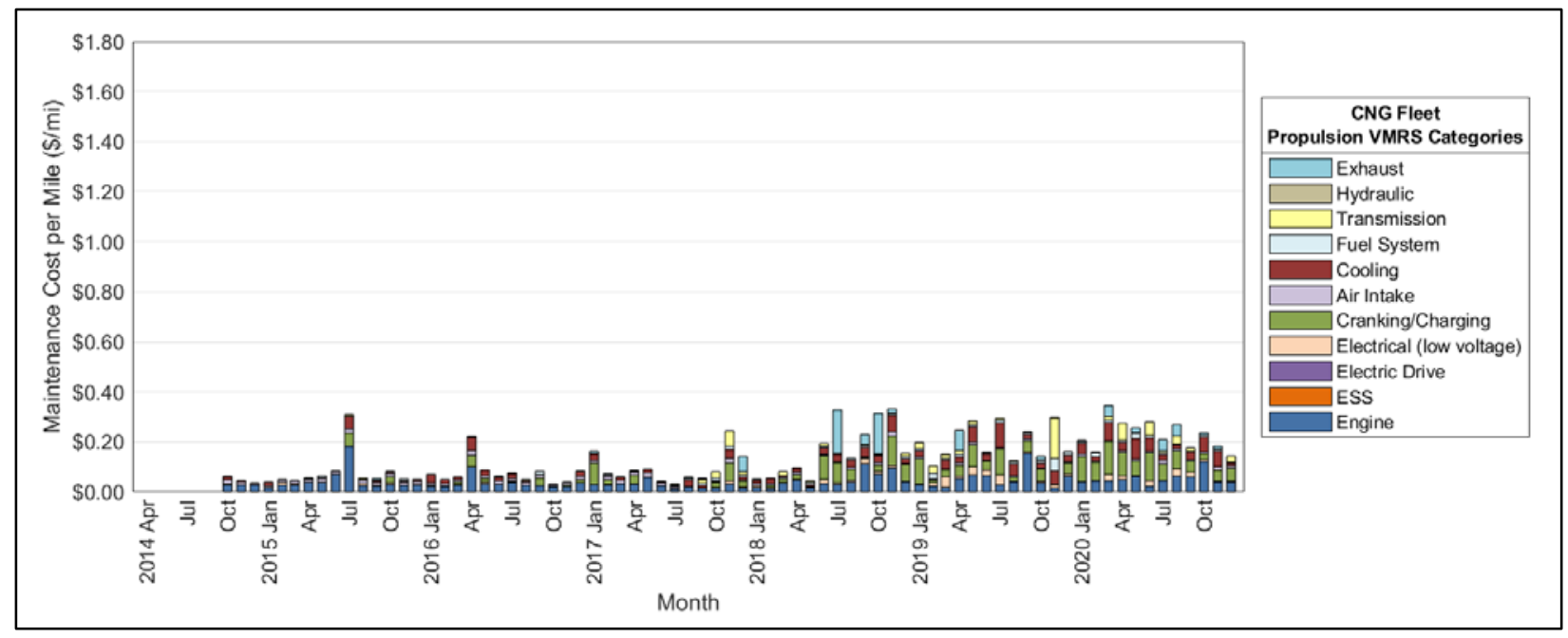

Figure 42. Monthly maintenance cost per mile by propulsion subsystem for the CNG fleet

\subsubsection{Summary of Maintenance Issues}

Since placing the BEBs into service, Foothill Transit has experienced several issues that caused downtime and resulted in higher maintenance costs. This section outlines the most significant issues.

Low-voltage batteries - The BEBs are equipped with two low-voltage batteries that enable startup of the bus and power some accessory loads. Early in the deployment of the BEB 35FC fleet, Foothill Transit began experiencing issues with premature failure of these low-voltage batteries. One issue is that the accessories (farebox, cameras, radio) continually draw power from these batteries. In some cases, the operators were not turning off the master switch, which allows the accessories to continue to draw power. If a bus sits idle for several days, the continual draw will completely drain the batteries. The maintenance contractor switched to a better-performing battery, but the batteries still failed at a high rate. The BEB 40FC buses also experience this issue. Proterra was made aware of the problem and has designed an automatic shutoff to address the problem. All new buses built by the OEM include this feature. Proterra also designed a 
retrofit for older bus models purchased prior to the design change, but this retrofit has not been completed on the Foothill Transit BEBs.

The low-voltage batteries on the BEB 35FC and BEB $40 \mathrm{FC}$ fleets have been replaced a total of 178 times since January 2015. This equates to approximately 10 battery changeouts per 100,000 miles. On a per-bus basis, the fleet averaged 12.7 battery changeouts during the evaluation period. The CNG buses are equipped with four low-voltage batteries but have an automatic disconnect feature. For comparison, the CNG baseline bused averaged three battery changeouts per bus -0.9 per 100,000 miles. Comparing the difference in cost for the low-voltage battery system on a per-mile basis, the BEB $35 \mathrm{FC}$ buses had an overall cost of $\$ 0.06$ per mile, the BEB $40 \mathrm{FC}$ buses had a cost of $\$ 0.11$ per mile, and the CNG buses had a cost of $\$ 0.01$ per mile.

Tire wear-The BEB 35FC and BEB 40FC fleets continue to experience higher tire wear compared to the CNG buses. Since the BEBs went into service, Foothill Transit has replaced 292 tires at a parts cost of more than $\$ 112,000$ and 303 labor hours. Average cost per bus is $\$ 8,012$ for parts and 21.7 labor hours. The CNG buses also had significant tire costs during the data period. The agency replaced 256 tires at a cost of more than $\$ 68,800$ for parts and 256 labor hours. The per-bus average cost for the eight-bus CNG fleet is $\$ 8,607$ for parts and 32 labor hours. The tires used are similar between fleets, but the fleets are operated in different servicethe BEBs are used only on local routes, which tend to have more road damage such as potholes and broken curbs, whereas the CNG buses are operated on both local roads and highways. This differing use results in a higher mileage accumulation for the CNG buses, and road conditions could contribute to different tire wear between fleets. When taking mileage into account, the BEBs travel an average of 5,920 miles per tire and have a cost of $\$ 0.07$ per mile. The CNG buses travel 10,796 miles per tire and have a cost of $\$ 0.03$ per mile.

On-route charging system thermal events-Foothill Transit's fast-charge BEBs are designed with a unique overhead docking and charging system that connects electrical contactors on the roof of the bus to corresponding electrical contactors in the overhead charging assembly to deliver a charge. Foothill Transit experienced three thermal incidents with BEBs and overhead chargers in late 2019 and in 2020 . These incidents resulted in damage to the charger blades on three buses and damage to three separate overhead chargers - both charging heads at the PTC and one charger at Arcadia. An investigation was conducted and Foothill Transit reports that these thermal events likely resulted from poor connections between the electrical contactors in the charger head and those on the bus rooftop. Bolts securing the contactors had become loose over time and the protruding heads of the bolts caused physical damage and misalignment of the contactors, resulting in high electrical resistance and/or electrical arcing that caused a fire to ignite at the charger interface. Foothill Transit worked with Proterra to identify the cause and correct the issue. Concurrently, Proterra had been redesigning the overhead charging system for improved performance and safety and was able to install the latest design on these chargers.

Parts availability and cost - Foothill Transit reports that availability of parts has been an issue for the BEBs. Once the buses were out of the warranty period and parts cost became the agency's responsibility, some advanced technology parts were expensive. For example, a DC-DC converter for the BEB 35FC fleet costs more than $\$ 12,600$ and a traction motor costs approximately $\$ 14,600$. Proterra reports that for the newer design BEBs, several of the advanced 
technology parts are lower in cost. For example, the cost for a DC-DC converter in the Catalyst model is about three times less. 


\section{BEB Evaluation Results: Arcadia}

The results presented in this section present data on the Arcadia buses from January 2020 through December 2020. The buses evaluated include the 14 BEB 40E2 and 14 New Flyer 40-ft CNG buses as a baseline. Although Foothill Transit's 35-ft E2 buses (BEB 35E2) are not a focus of this report, NREL collects mileage and energy from these buses. This is necessary to calculate cost per mile for Arcadia because all 17 BEBs are charged at the facility. The utility data are not separated by bus, so the data from all buses are required for the calculation. Appendix E provides a detailed summary of the Arcadia bus operation and costs. Appendix F provides a summary of results in metric units.

\subsection{Route Assignments}

Foothill Transit uses the BEB 40E2 buses primarily on Line 280 (Figure 43), which cycles through the Azusa Intermodal Transit Center, allowing for supplemental charging at the fastcharge station to increase range. The BEB 40E2 fleet operating on Line 280 has an average overall speed of $21.0 \mathrm{mph}$. The CNG buses are randomly dispatched on all routes out of the Arcadia facility, including commuter routes. Average speed for all Arcadia operations is approximately $17 \mathrm{mph}$. Foothill Transit operates the BEB 35E2 fleet on a circulator route for the City of Duarte. This route (Line 860 and Line 861 ) runs through the city and residential areas with narrow streets and parked cars, which requires shorter buses. Figure 44 displays the route maps for Line 860 and 861, which are similar but follow different paths depending on the direction of travel. The BEB 35E2 fleet on Line 860/861 averages 17.9 mph overall.

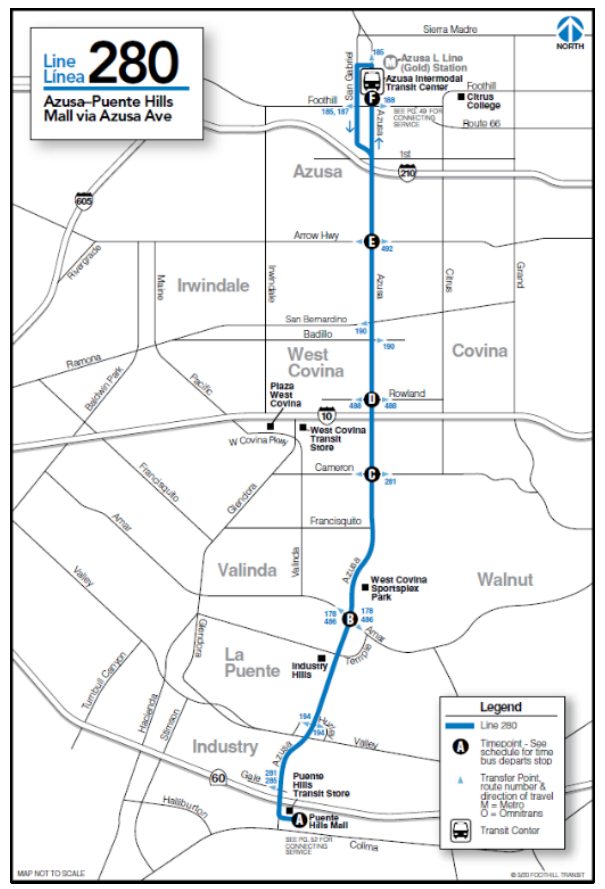

Figure 43. Route map for Line 280

Image courtesy of Foothill Transit 

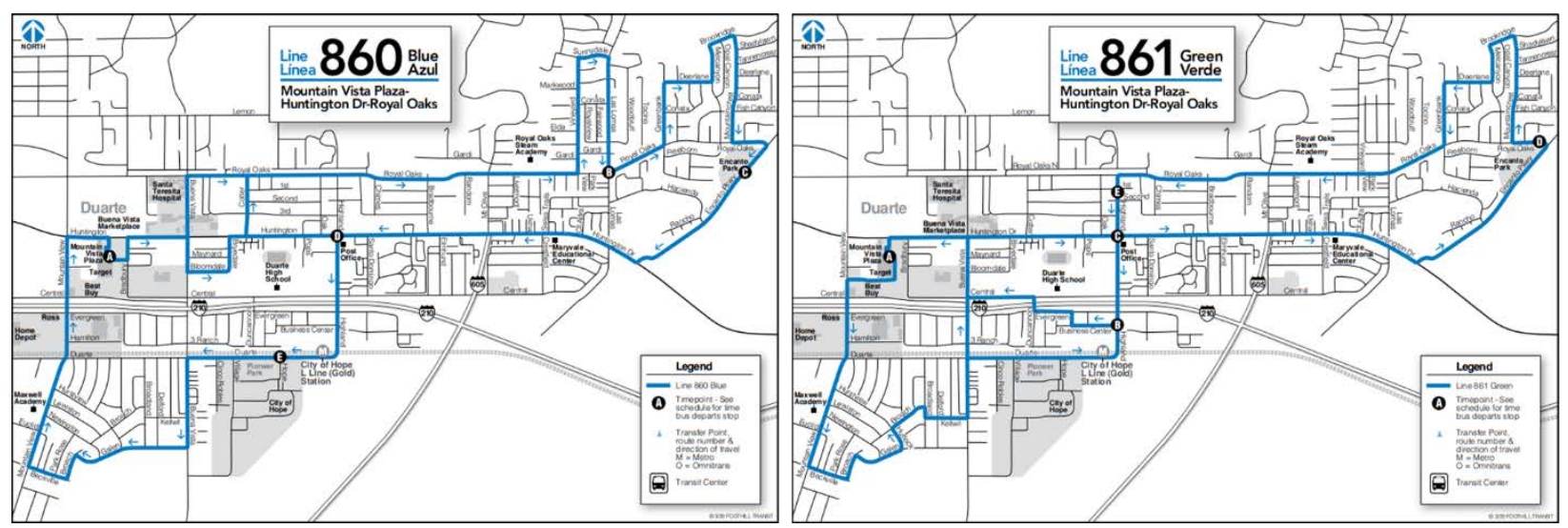

Figure 44. Route maps for Line 860 and Line 861

Images courtesy of Foothill Transit

\subsection{Bus Availability}

This section summarizes bus availability for the BEBs and CNG baseline buses at Arcadia. The Arcadia fleets are scheduled to operate every day, including weekends. As with the Pomona facility, the availability analysis for Arcadia was derived from garage activity sheets that list all buses that are not available for service at morning pull-out each day. The garage activity sheets were not available for every day; during the data period, $68 \%$ of the activity sheets were available for NREL's analysis.

Table 16 summarizes the availability for the BEB 40E2 fleet during the 1-year evaluation period. The per-bus availability ranges from a high of $95.2 \%$ to a low of $43.3 \%$. The overall average for the fleet is $81.9 \%$. The per-bus CNG availability in Table 17 ranges from a high of $98.0 \%$ to a low of $88.4 \%$, with an overall fleet average of $93.5 \%$. Figure 45 and Figure 46 show the monthly availability trends for the BEB 40E2 fleet and CNG fleet, respectively, including stacked columns that indicate the number of unavailable days for each category of downtime. Table 18 and Figure 47 provide a summary of the overall availability and reasons for unavailability for the Arcadia fleets.

Most of the downtime for the BEBs was related to general bus maintenance issues. The BEB fleet also experienced downtime due to transmission issues and a few problems with electric drive systems in the second half of the evaluation period. The CNG fleet had higher availability overall, which is expected for an incumbent technology that maintenance staff are familiar with troubleshooting and repairing. The primary reasons for CNG fleet downtime were divided between general bus-related maintenance and engine issues. Preventive maintenance inspections accounted for $1.0 \%$ or less of the downtime for both bus fleets. 
Table 16. Summary of Availability by Bus for the Arcadia BEB 40E2 Fleet

\begin{tabular}{|c|c|c|c|}
\hline Bus ID & $\begin{array}{c}\text { Planned } \\
\text { Days }\end{array}$ & $\begin{array}{c}\text { Available } \\
\text { Days }\end{array}$ & $\begin{array}{c}\text { Percent } \\
\text { Availability }\end{array}$ \\
\hline 2600 & 249 & 217 & 87.1 \\
\hline 2601 & 248 & 180 & 72.6 \\
\hline 2602 & 248 & 223 & 89.9 \\
\hline 2603 & 248 & 203 & 81.9 \\
\hline 2604 & 249 & 211 & 84.7 \\
\hline 2605 & 249 & 223 & 89.6 \\
\hline 2606 & 249 & 223 & 89.6 \\
\hline 2607 & 249 & 237 & 95.2 \\
\hline 2608 & 208 & 90 & 43.3 \\
\hline 2609 & 249 & 207 & 83.1 \\
\hline 2610 & 249 & 230 & 92.4 \\
\hline 2611 & 249 & 147 & 59.0 \\
\hline 2016 & 249 & 231 & 92.8 \\
\hline 2017 & 230 & 182 & 79.1 \\
\hline BEB 40E2 & 3,423 & 2,804 & 81.9 \\
\hline Fleet & & & \\
\hline
\end{tabular}

Table 17. Summary of Availability by Bus for the Arcadia CNG Fleet

\begin{tabular}{|c|c|c|c|}
\hline Bus ID & $\begin{array}{l}\text { Planned } \\
\text { Days }\end{array}$ & $\begin{array}{c}\text { Available } \\
\text { Days }\end{array}$ & $\begin{array}{c}\text { Percent } \\
\text { Availability }\end{array}$ \\
\hline 2516 & 249 & 236 & 94.8 \\
\hline 2517 & 249 & 231 & 92.8 \\
\hline 2518 & 249 & 237 & 95.2 \\
\hline 2519 & 249 & 230 & 92.4 \\
\hline 2520 & 249 & 244 & 98.0 \\
\hline 2521 & 249 & 235 & 94.4 \\
\hline 2522 & 249 & 223 & 89.6 \\
\hline 2523 & 249 & 240 & 96.4 \\
\hline 2524 & 249 & 242 & 97.2 \\
\hline 2525 & 249 & 234 & 94.0 \\
\hline 2526 & 224 & 201 & 89.7 \\
\hline 2527 & 249 & 230 & 92.4 \\
\hline 2528 & 249 & 234 & 94.0 \\
\hline 2529 & 249 & 220 & 88.4 \\
\hline CNG Fleet & 3,461 & 3,237 & 93.5 \\
\hline
\end{tabular}




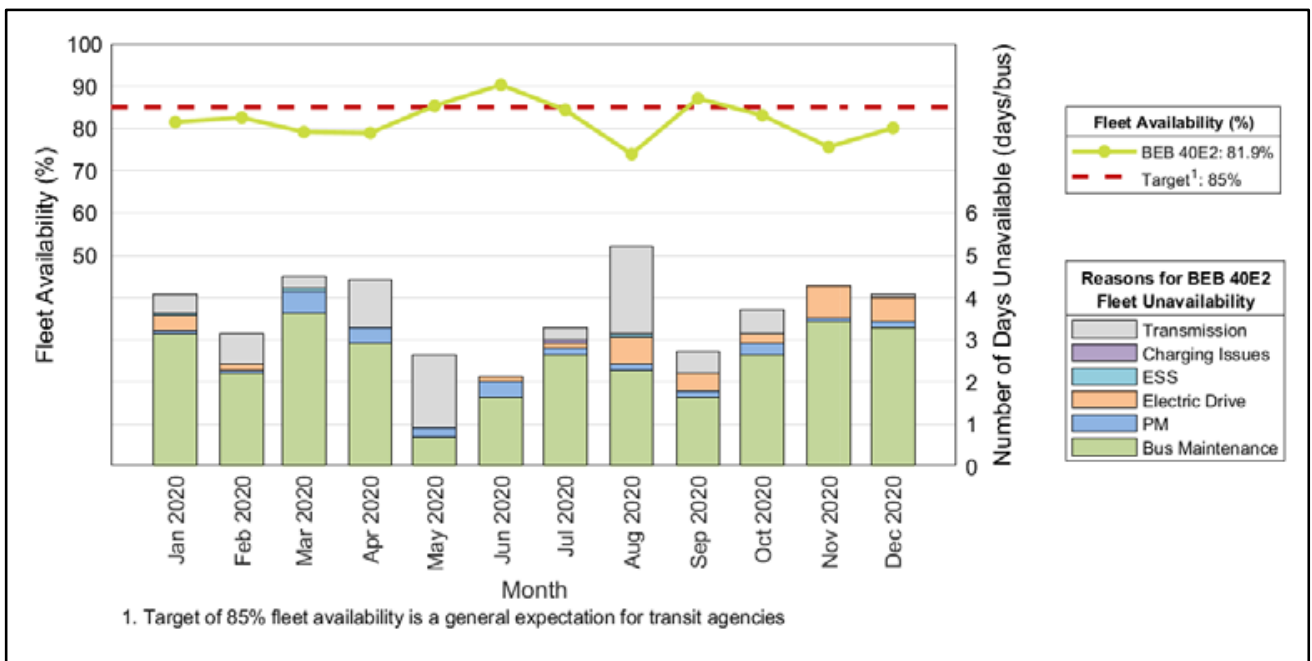

Figure 45. Monthly availability for the BEB 40E2 fleet

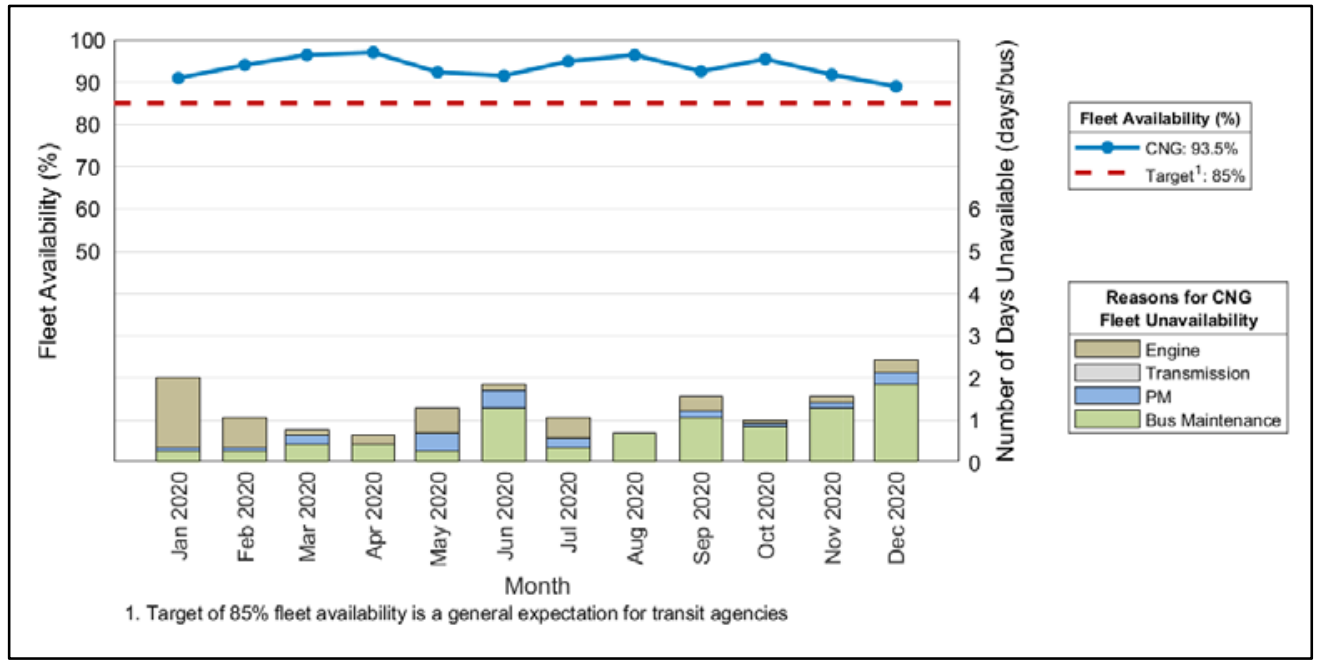

Figure 46. Monthly availability for the CNG fleet

Table 18. Summary of Availability and Unavailable Days for the BEB $40 E 2$ and CNG Fleets

\begin{tabular}{|l|c|c|c|c|}
\multicolumn{1}{c}{} & \multicolumn{2}{c}{ BEB 40E2 } & \multicolumn{2}{c|}{ CNG } \\
\hline Planned work days & $\mathbf{3 , 4 2 3}$ & - & $\mathbf{3 , 4 6 1}$ & - \\
\hline Available days & 2,804 & 81.9 & 3,237 & 93.5 \\
\hline Unavailable days & $\mathbf{6 1 9}$ & $\mathbf{1 8 . 1}$ & $\mathbf{2 2 4}$ & $\mathbf{6 . 5}$ \\
\hline ESS & 3 & 0.1 & - & - \\
\hline CNG engine & - & - & 67 & 1.9 \\
\hline Electric drive & 48 & 1.4 & - & - \\
\hline Charging issues & 1 & 0.0 & - & - \\
\hline Preventive maintenance & 35 & 1.0 & 29 & 0.8 \\
\hline General bus maintenance & 423 & 12.4 & 128 & 3.7 \\
\hline Transmission & 109 & 3.2 & 0 & 0.0 \\
\hline
\end{tabular}




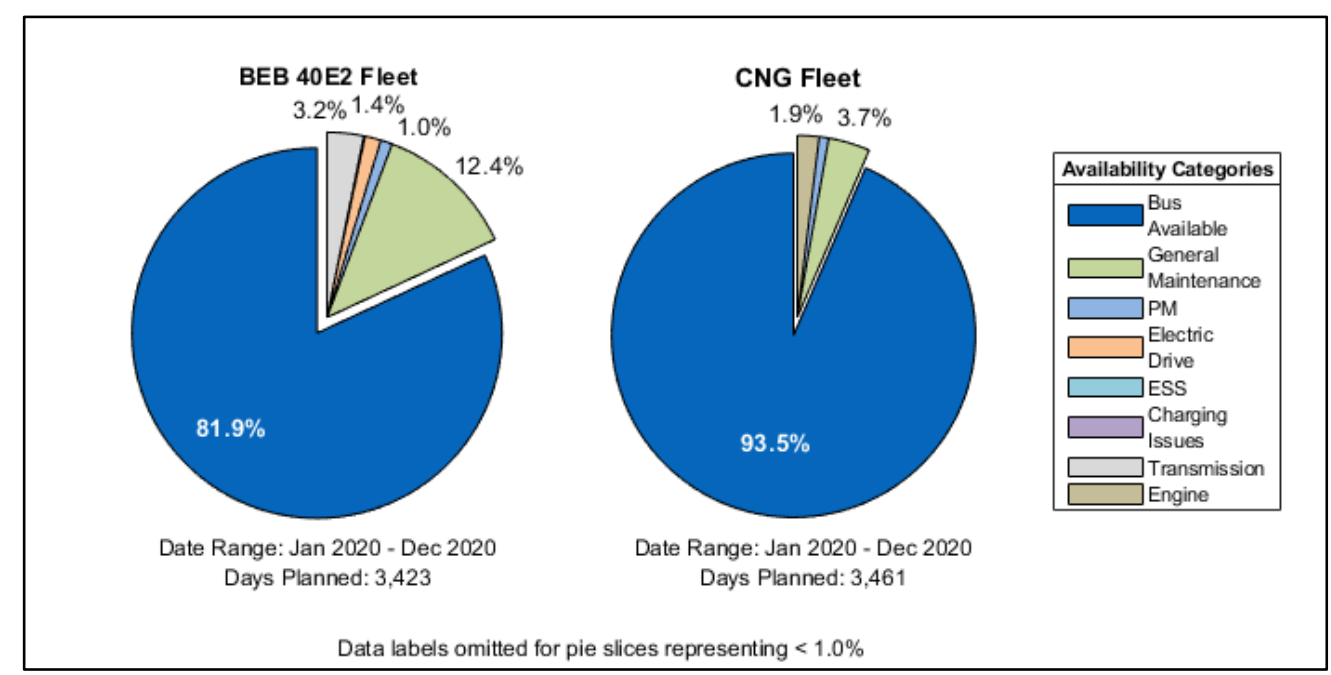

Figure 47. Cumulative availability for the BEB 40E2 and CNG fleets

\subsection{Bus Mileage, Energy Use, and Fuel Economy}

Foothill Transit began receiving the extended-range BEBs in 2017. At that time, the charging infrastructure needed to consistently operate the new fleets in passenger service was not completed. Foothill Transit used some of the BEBs for training and testing activities until the charging infrastructure was completed and fully commissioned at the end of 2019. January 2020 was selected at the clean point for the evaluation to coincide with the new BEB fleets (BEB $40 \mathrm{E} 2$ and BEB 35E2) being placed into full passenger service on their scheduled routes. Figure 48 shows the accumulation of miles for the BEBs from all data received by NREL since the BEBs were delivered. During 2020, the BEB 40E2 fleet (14 BEBs) accumulated 507,619 miles and the BEB 35E2 fleet (3 BEBs) accumulated 100,130 miles in service. The baseline CNG buses selected for this evaluation were new 40-ft buses also placed into service in January 2020. This fleet (14 buses) accumulated 787,353 miles in the first year of operation.

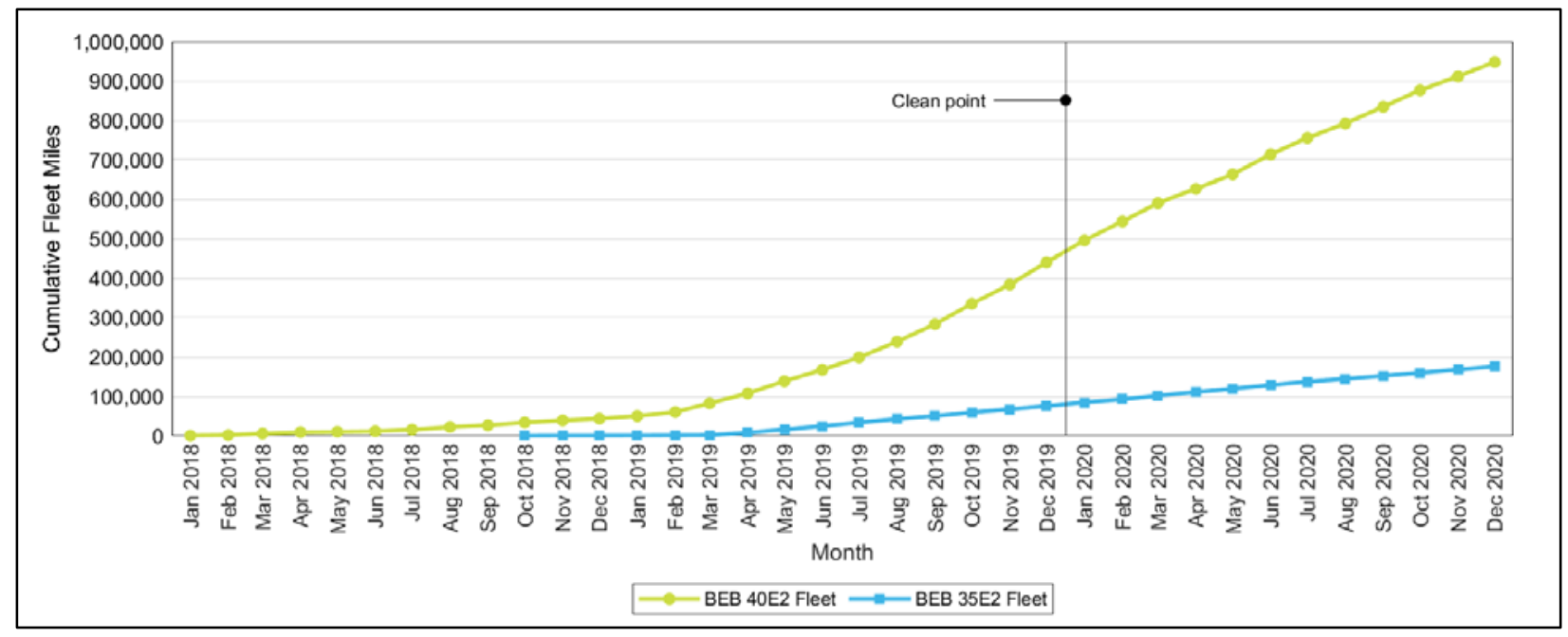

Figure 48. Cumulative miles for the Arcadia BEB fleets

Table 19 and Table 20 summarize the overall mileage for each bus in the BEB and CNG fleets, respectively, and Figure 49 compares the average monthly mileage trends between the three 
fleets. The overall monthly average for the BEB 40E2 fleet was 3,022 miles per bus and the BEB 35E2 fleet averaged 2,781 miles per bus per month. The CNG fleet had a much higher monthly average of 4,687 miles per bus. Again, the randomly dispatched CNG buses that service some commuter routes are expected to accumulate more miles than the BEBs, which are scheduled for a slower-speed route.

Table 19. Average Monthly Miles, BEB 40E2 Fleet

\begin{tabular}{|c|c|c|c|c|}
\hline Bus ID & $\begin{array}{c}\text { Start } \\
\text { Month }\end{array}$ & Miles & Bus & $\begin{array}{c}\text { Average } \\
\text { Months }\end{array}$ \\
\hline 2600 & Jan. 2020 & 26,752 & 12 & 2,229 \\
\hline 2601 & Jan. 2020 & 33,025 & 12 & 2,752 \\
\hline 2602 & Jan. 2020 & 41,890 & 12 & 3,491 \\
\hline 2603 & Jan. 2020 & 35,966 & 12 & 2,997 \\
\hline 2604 & Jan. 2020 & 37,787 & 12 & 3,149 \\
\hline 2605 & Jan. 2020 & 41,464 & 12 & 3,455 \\
\hline 2606 & Jan. 2020 & 42,174 & 12 & 3,515 \\
\hline 2607 & Jan. 2020 & 44,245 & 12 & 3,687 \\
\hline 2608 & Jan. 2020 & 17,443 & 12 & 1,454 \\
\hline 2609 & Jan. 2020 & 38,874 & 12 & 3,240 \\
\hline 2610 & Jan. 2020 & 43,898 & 12 & 3,658 \\
\hline 2611 & Jan. 2020 & 26,146 & 12 & 2,179 \\
\hline 2612 & Jan. 2020 & 42,792 & 12 & 3,566 \\
\hline 2613 & Jan. 2020 & 35,161 & 12 & 2,930 \\
\hline BEB 40E2 & & $\mathbf{5 0 7 , 6 1 9}$ & 168 & 3,022 \\
\hline Fleet & & 33,759 & 12 & 2,813 \\
\hline 2800 & Jan. 2020 & 30,461 & 12 & 2,538 \\
\hline 2801 & Jan. 2020 & 30,499 \\
\hline 2602 & Jan. 2020 & 35,909 & 12 & 2,992 \\
\hline BEB 35E2 & & $\mathbf{1 0 0 , 1 3 0}$ & $\mathbf{3 6}$ & $\mathbf{2 , 7 8 1}$ \\
\hline Fleet & & & & \\
\hline
\end{tabular}


Table 20. Average Monthly Miles, CNG Fleet

\begin{tabular}{|c|c|c|c|c|}
\hline Bus ID & $\begin{array}{c}\text { Start } \\
\text { Month }\end{array}$ & Miles & $\begin{array}{c}\text { Bus } \\
\text { Months }\end{array}$ & $\begin{array}{c}\text { Average } \\
\text { Monthly Miles }\end{array}$ \\
\hline 2516 & Jan. 2020 & 56,174 & 12 & 4,681 \\
\hline 2517 & Jan. 2020 & 55,099 & 12 & 4,592 \\
\hline 2518 & Jan. 2020 & 58,050 & 12 & 4,838 \\
\hline 2519 & Jan. 2020 & 56,001 & 12 & 4,667 \\
\hline 2520 & Jan. 2020 & 58,689 & 12 & 4,891 \\
\hline 2521 & Jan. 2020 & 55,922 & 12 & 4,660 \\
\hline 2522 & Jan. 2020 & 54,927 & 12 & 4,577 \\
\hline 2523 & Jan. 2020 & 59,062 & 12 & 4,922 \\
\hline 2524 & Jan. 2020 & 58,892 & 12 & 4,908 \\
\hline 2525 & Jan. 2020 & 55,152 & 12 & 4,596 \\
\hline 2526 & Jan. 2020 & 51,322 & 12 & 4,277 \\
\hline 2527 & Jan. 2020 & 57,458 & 12 & 4,788 \\
\hline 2528 & Jan. 2020 & 57,958 & 12 & 4,830 \\
\hline 2529 & Jan. 2020 & 52,647 & 12 & 4,387 \\
\hline CNG Fleet & & $\mathbf{7 8 7 , 3 5 3}$ & $\mathbf{1 6 8}$ & $\mathbf{4 , 6 8 7}$ \\
\hline
\end{tabular}

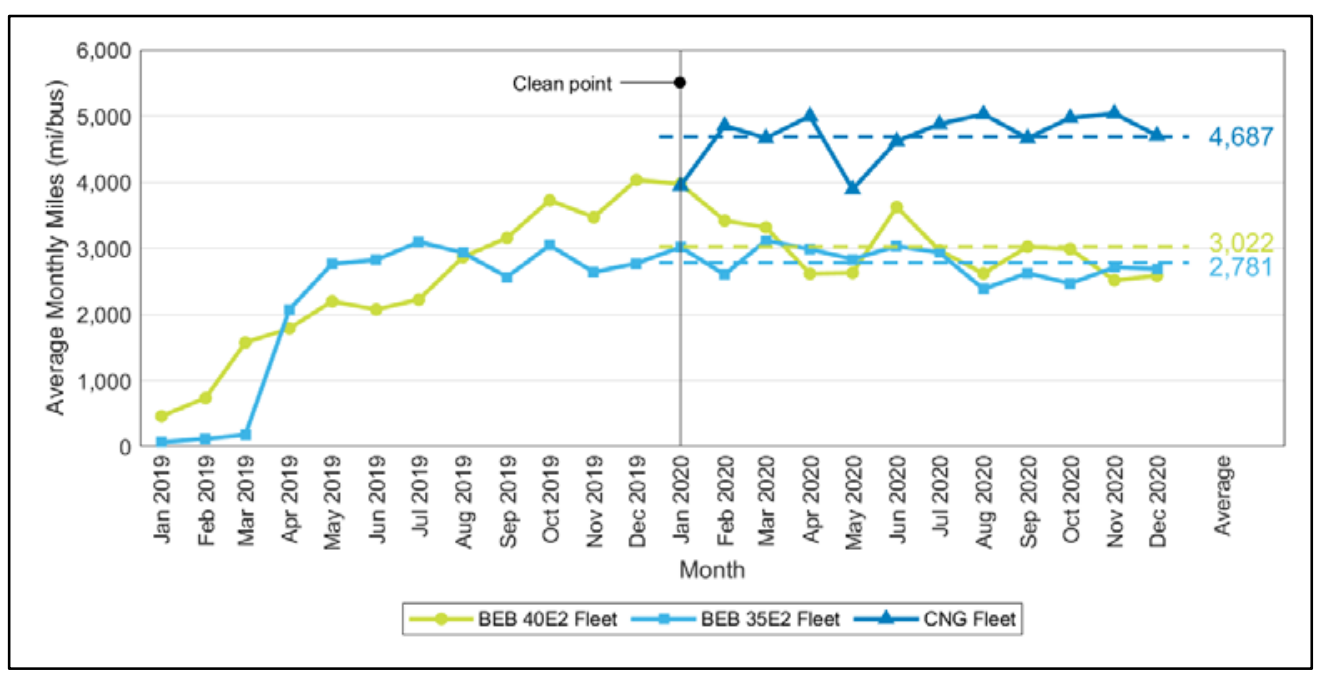

Figure 49. Average monthly miles for the Arcadia BEB and CNG fleets

Table 21 and Table 22 summarize the mileage, energy consumption, and fuel economy for the BEB 40E2 fleet and the CNG fleet at Arcadia, respectively. As with the Pomona fleets, the electricity consumption of the BEBs and the fuel consumption of the CNG buses were both converted to dge units for comparison. The BEB 40E2 fleet had an overall average fuel economy of 19.76 mpdge, which is five times that of the CNG average of 3.88 mpdge. The CNG fuel economy is very consistent throughout the year, whereas the BEB fuel economy displays some minor seasonal variation due to ambient temperature changes, as shown in Figure 50. 
Table 21. Total Miles, Fuel Consumption, and Fuel Economy, BEB 40E2 Fleet

\begin{tabular}{|c|c|c|c|c|c|}
\hline Bus ID & $\begin{array}{c}\text { Fuel } \\
\text { Miles }\end{array}$ & $\begin{array}{c}\text { Fuel } \\
\text { Consumption } \\
\text { (BEB: kWh) }\end{array}$ & $\begin{array}{c}\text { Consumption } \\
\text { (dge) }\end{array}$ & $\begin{array}{c}\text { Fuel Economy } \\
\text { (BEB: } \\
\text { kWh/mi) }\end{array}$ & $\begin{array}{c}\text { Fuel Economy } \\
\text { (mpdge) }\end{array}$ \\
\hline 2600 & 26,752 & 51,748 & 1,375 & 1.93 & 19.46 \\
\hline 2601 & 33,025 & 64,131 & 1,704 & 1.94 & 19.38 \\
\hline 2602 & 41,890 & 80,623 & 2,142 & 1.92 & 19.55 \\
\hline 2603 & 35,966 & 66,925 & 1,778 & 1.86 & 20.23 \\
\hline 2604 & 37,787 & 73,837 & 1,962 & 1.95 & 19.26 \\
\hline 2605 & 41,464 & 79,219 & 2,105 & 1.91 & 19.70 \\
\hline 2606 & 42,174 & 79,665 & 2,117 & 1.89 & 19.92 \\
\hline 2607 & 44,245 & 81,484 & 2,165 & 1.84 & 20.44 \\
\hline 2608 & 17,443 & 33,005 & 877 & 1.89 & 19.89 \\
\hline 2609 & 38,874 & 76,419 & 2,031 & 1.97 & 19.15 \\
\hline 2610 & 43,898 & 83,485 & 2,218 & 1.90 & 19.79 \\
\hline 2611 & 26,146 & 49,478 & 1,315 & 1.89 & 19.89 \\
\hline 2612 & 42,792 & 80,595 & 2,141 & 1.88 & 19.98 \\
\hline 2613 & 35,161 & 65,993 & 1,753 & 1.88 & 20.05 \\
\hline BEB 40E2 & $\mathbf{5 0 7 , 6 1 9}$ & 966,606 & 25,683 & 1.90 & 19.76 \\
\hline Fleet & & & & & \\
\hline
\end{tabular}

Table 22. Total Miles, Fuel Consumption, and Fuel Economy, CNG Fleet

\begin{tabular}{|c|c|c|c|c|c|}
\hline Bus ID & $\begin{array}{c}\text { Fuel } \\
\text { Miles }\end{array}$ & $\begin{array}{c}\text { Consumption } \\
\text { (CNG: gge) }\end{array}$ & $\begin{array}{c}\text { Consumption } \\
\text { (dge) }\end{array}$ & $\begin{array}{c}\text { Fuel Economy } \\
\text { (CNG: mpgge) }\end{array}$ & $\begin{array}{c}\text { Fuel Economy } \\
\text { (mpdge) }\end{array}$ \\
\hline 2516 & 5,510 & 1,486 & 1,297 & 3.71 & 4.25 \\
\hline 2517 & 1,525 & 410 & 358 & 3.72 & 4.26 \\
\hline 2518 & 3,531 & 1,010 & 881 & 3.50 & 4.01 \\
\hline 2519 & 1,684 & 494 & 431 & 3.41 & 3.91 \\
\hline 2520 & 3,859 & 1,166 & 1,017 & 3.31 & 3.79 \\
\hline 2521 & 440 & 128 & 112 & 3.44 & 3.94 \\
\hline 2522 & 2,273 & 742 & 647 & 3.07 & 3.51 \\
\hline 2523 & 2,292 & 698 & 609 & 3.28 & 3.76 \\
\hline 2524 & 3,461 & 1,082 & 944 & 3.20 & 3.66 \\
\hline 2525 & 3,663 & 1,077 & 940 & 3.40 & 3.90 \\
\hline 2526 & 1,175 & 356 & 311 & 3.30 & 3.78 \\
\hline 2527 & 1,619 & 514 & 448 & 3.15 & 3.61 \\
\hline 2528 & 872 & 293 & 256 & 2.98 & 3.41 \\
\hline 2529 & 2,485 & 710 & 619 & 3.50 & 4.01 \\
\hline CNG Fleet & $\mathbf{3 4 , 3 8 9}$ & $\mathbf{1 0 , 1 6 4}$ & $\mathbf{8 , 8 6 9}$ & $\mathbf{3 . 3 8}$ & 3.88 \\
\hline
\end{tabular}




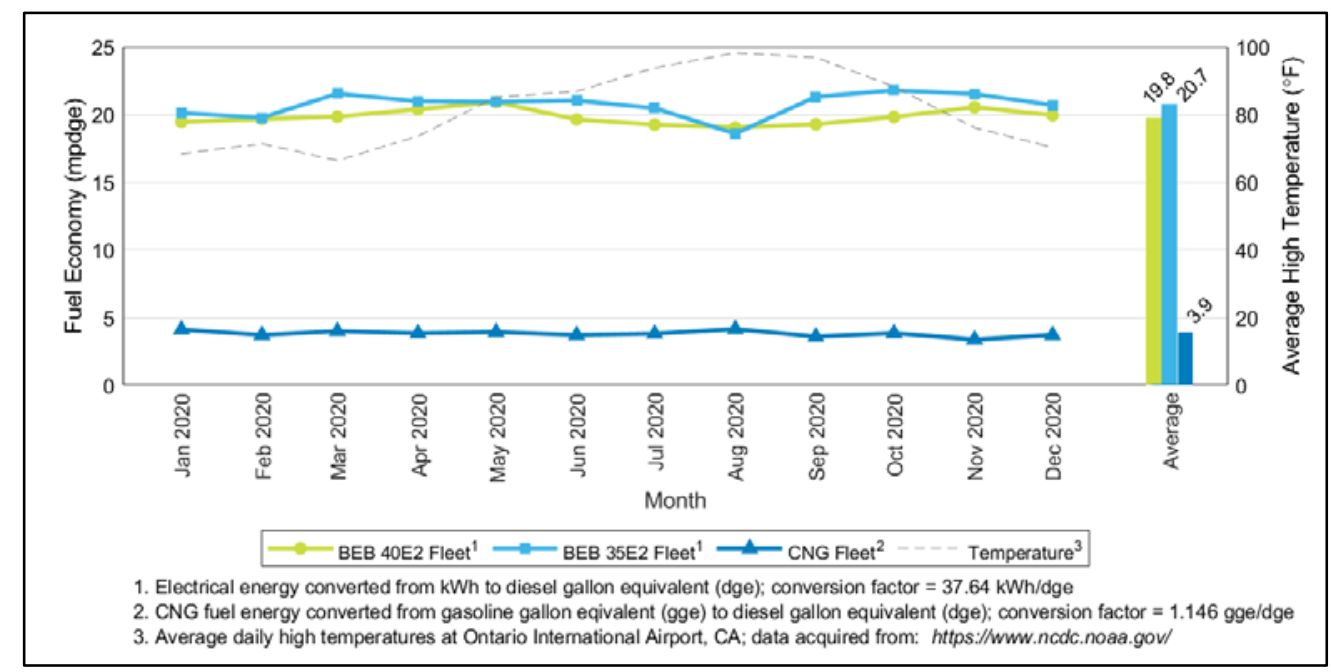

Figure 50. Monthly average fuel economy for the BEB and CNG fleets

Detailed energy data from the BEB telemetry, collected and made available by Proterra, provide a breakdown of the energy consumption by the BEBs operating at Arcadia. Figure 51 reveals that the BEBs recover — or return to the ESS through regenerative braking (regen) $-24 \%$ of the propulsion energy, on average. This is one of the reasons the BEBs achieve much higher fuel economy than conventional diesel and $\mathrm{CNG}$ buses. The second pie chart in the figure shows the typical energy consumption by vehicle subsystem: $73 \%$ of the BEB energy consumption goes to the powertrain, $9 \%$ to defrost and battery thermal management (BTM), 7\% to the HVAC system, and the remainder is distributed to other small accessory loads such as power steering.

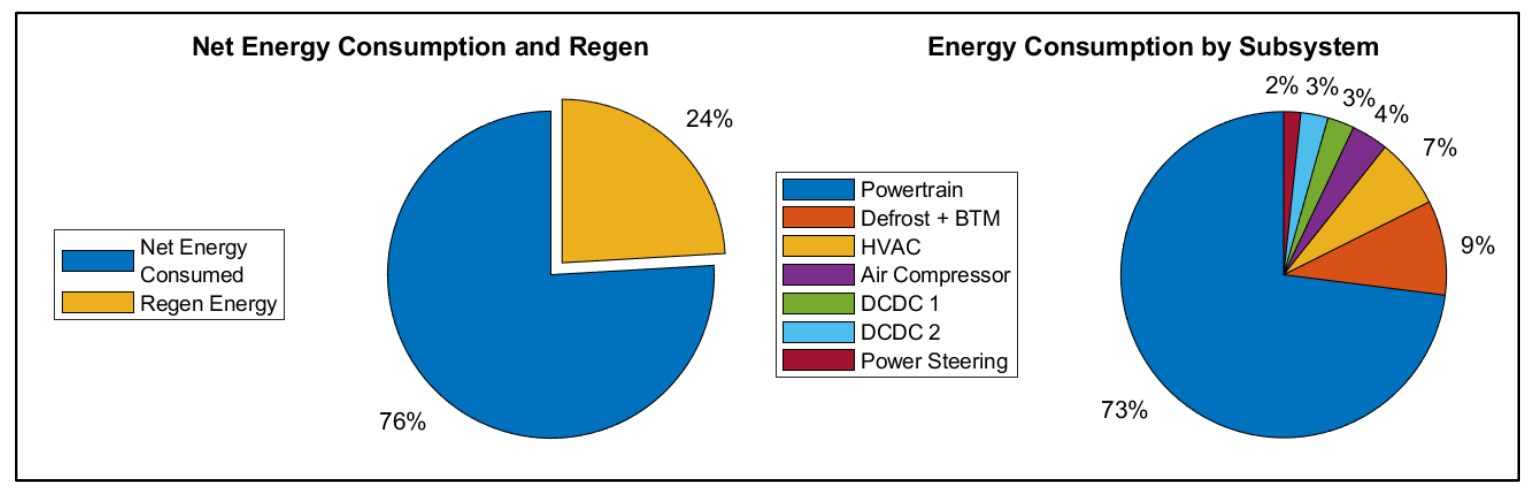

Figure 51. Energy regen and energy consumption by subsystem, BEB 40E2 fleet

\subsection{Charging Performance and Fuel Cost}

The extended-range BEBs at Arcadia are primarily charged with overnight charging at the depot but are also capable of using the on-route fast-charging stations when needed. Figure 52 shows the distributions of charge energy and charge duration for both charging methods. Depot charges deliver a wide range of energy, up to $300 \mathrm{kWh}$ per charging session, and can last up to 6 hours. On-route fast charging sessions typically deliver less than $80 \mathrm{kWh}$ in approximately 30 minutes or less. On-route charges are often limited to the time available during layovers, and thus do not always charge the ESS up to full (100\%) SOC. Conversely, depot charges usually end once the ESS has been fully charged. This is reflected in the first plot of Figure 53, which shows the charging session starting SOC, ending SOC, and the difference between the start and end (SOC 
charged) for both charging methods. Depot charging typically charges the BEBs up to full SOC, regardless of the starting SOC, whereas the SOC charged (and therefore, the energy delivered) for on-route charges is dictated by the charging time available.
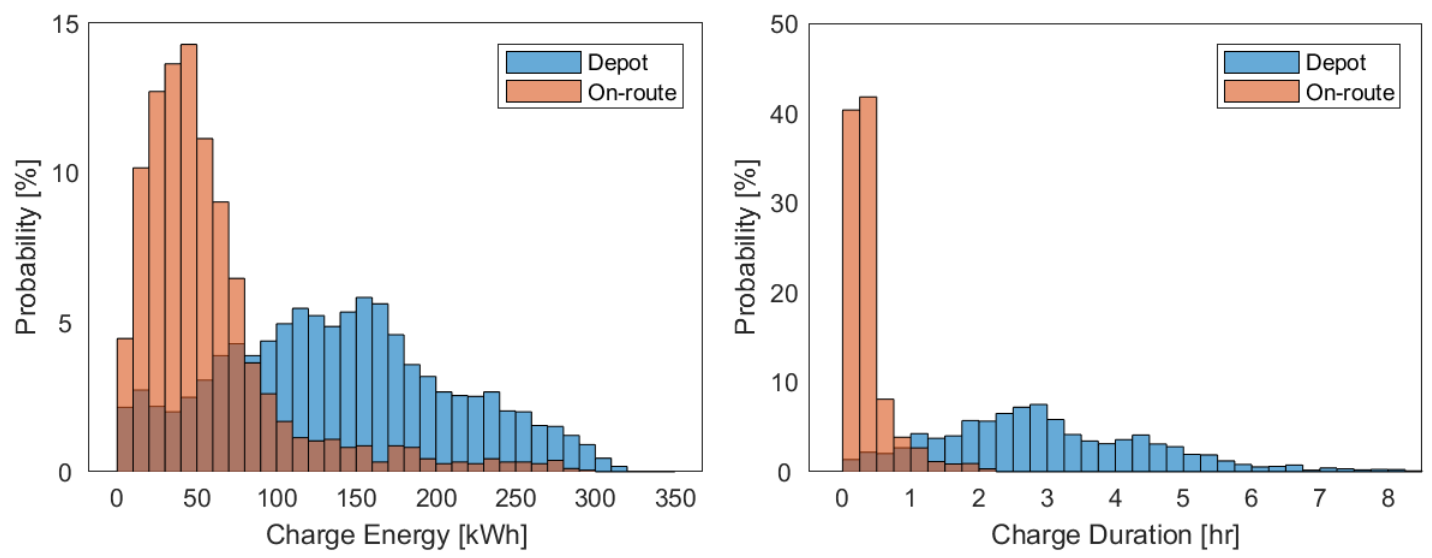

Figure 52. Charge energy and charge duration for the BEBs at Arcadia

The supplemental on-route charging received by the BEB 40E2 fleet allows the BEBs to extend their daily operating range. The daily distance distributions in Figure 53 show a peak near 150 miles per day for BEBs operating on the depot charge only, and a peak near 200 miles per day for BEBs that receive supplemental on-route charging in addition to overnight depot charging.
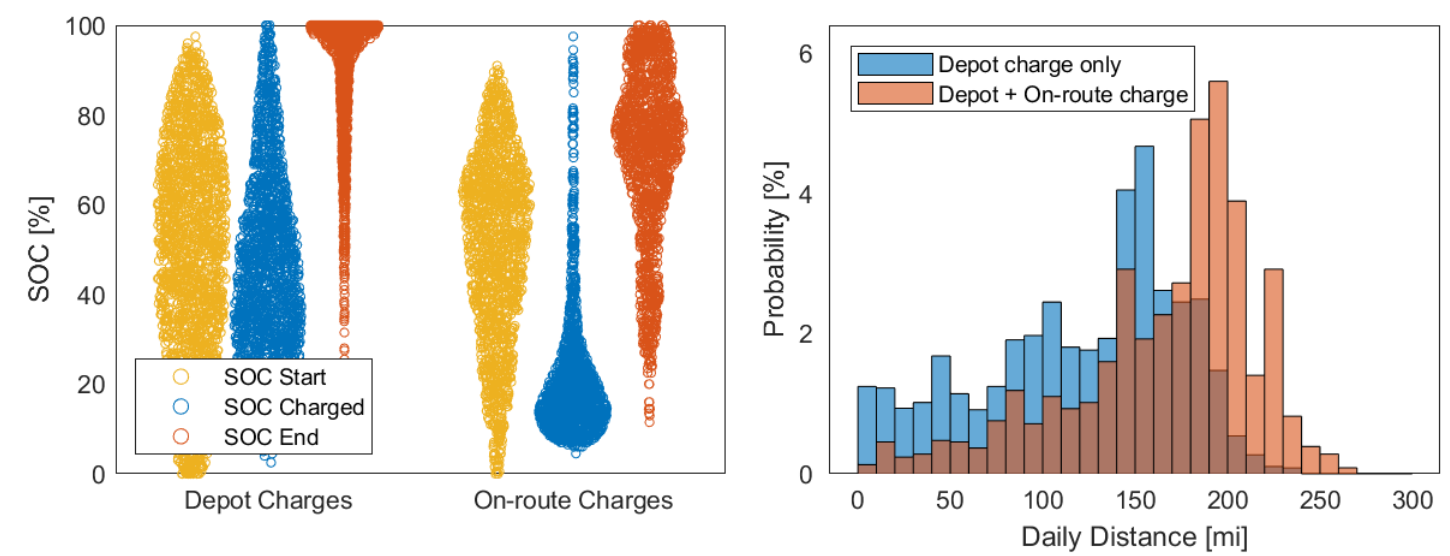

Figure 53. ESS SOC by charging method and BEB daily distance for the BEBs at Arcadia

As with the PTC fast chargers, the charging station at Arcadia depot has a dedicated utility meter to measure energy used to charge the BEB fleet. Detailed meter data and utility bills were provided to NREL for BEB charging and costs analysis. The charging station is currently billed under SCE's commercial electric vehicle rate structure TOU-EV-9, which includes TOU charges but no demand charges at this time.

The extended-range BEBs at Arcadia depot use overnight charging, which means many of the BEBs are charging at the same time, leading to a large electrical load at the charging station. Figure 54 shows the daily charging profile for the Arcadia BEB fleet, as measured by the utility meter. The time of day is shifted to show continuous overnight charging periods, and the weekday and weekend median trend lines are indicated by black and blue lines, respectively. 
Charging typically begins between 6 p.m. and 7 p.m. as BEBs begin returning to the depot after completing scheduled daily service. Foothill Transit staff try to minimize charging during on/mid-peak TOU periods (4-9 p.m.), delaying some charging until after 9 p.m. when the TOU period changes to off-peak electricity rates. However, the 14 chargers are shared amongst 17 BEBs, which necessitates charging a few BEBs as soon as possible to ensure all BEBs have sufficient time to fully charge prior to service the next day.

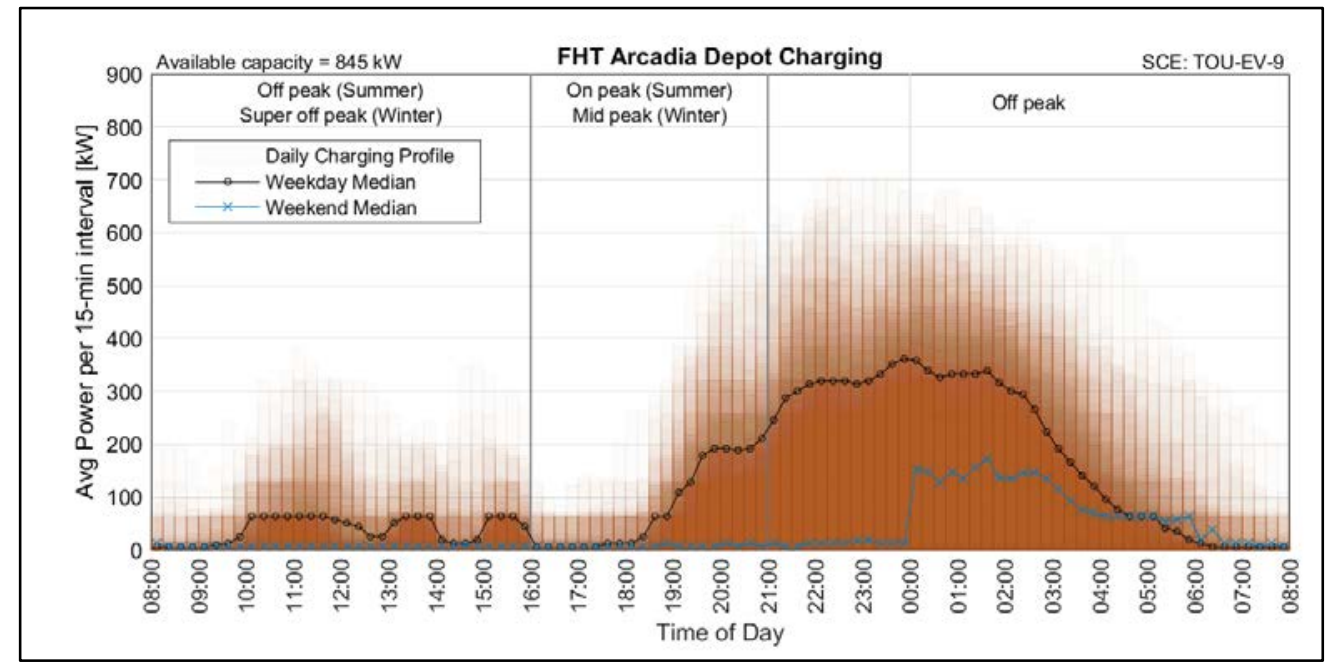

Figure 54. Daily total charging profile for BEB fleet at Arcadia depot

The heatmap in Figure 55 displays the same charging data for Arcadia, reformatted by time of day vs. day of the year. The colored regions correspond to the TOU categories shown in Figure 56-On Peak (red), Mid Peak (yellow), Off Peak (blue), and Super Off Peak (green). The heatmap view of the data also shows weekday charging typically beginning around 6-7 p.m. and ending in the early morning hours the following day, as well as limited midday charging. This view illustrates that a consistent charging strategy can lead to different energy costs throughout the year because the TOU categories change seasonally. The average energy consumption rates (in $\$ / \mathrm{kWh}$ ) shown in Figure 56 indicate that each TOU category costs approximately twice as much as the category just below it. At 9 p.m. during winter months, when the TOU category changes from Mid Peak to Off Peak, the energy consumption rate decreases from $\$ 0.26$ per $\mathrm{kWh}$ to $\$ 0.11$ per kWh. During summer months, the TOU category changes at 9 p.m. from On Peak to Off Peak, which drops the energy rate from $\$ 0.46$ per $\mathrm{kWh}$ to $\$ 0.11$ per $\mathrm{kWh}$. This substantial difference in the energy consumption rate charged by the utility highlights how the charging strategy and schedule for a BEB fleet can have a significant impact on the cost to operate the fleet. Charge management software that controls the timing and power levels for BEB charging can help transit agencies and other fleet operators manage electricity costs when TOU charges and demand charges are involved. 


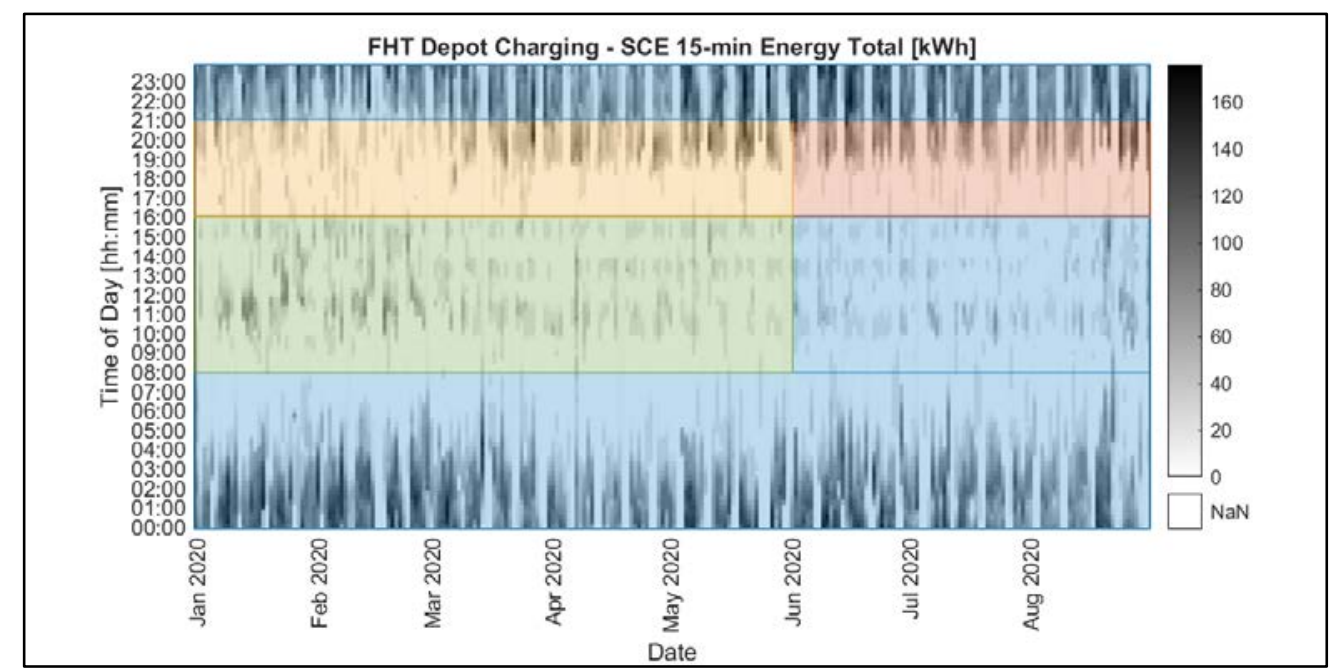

Figure 55. Heatmap of energy consumption by TOU category for Arcadia depot charging

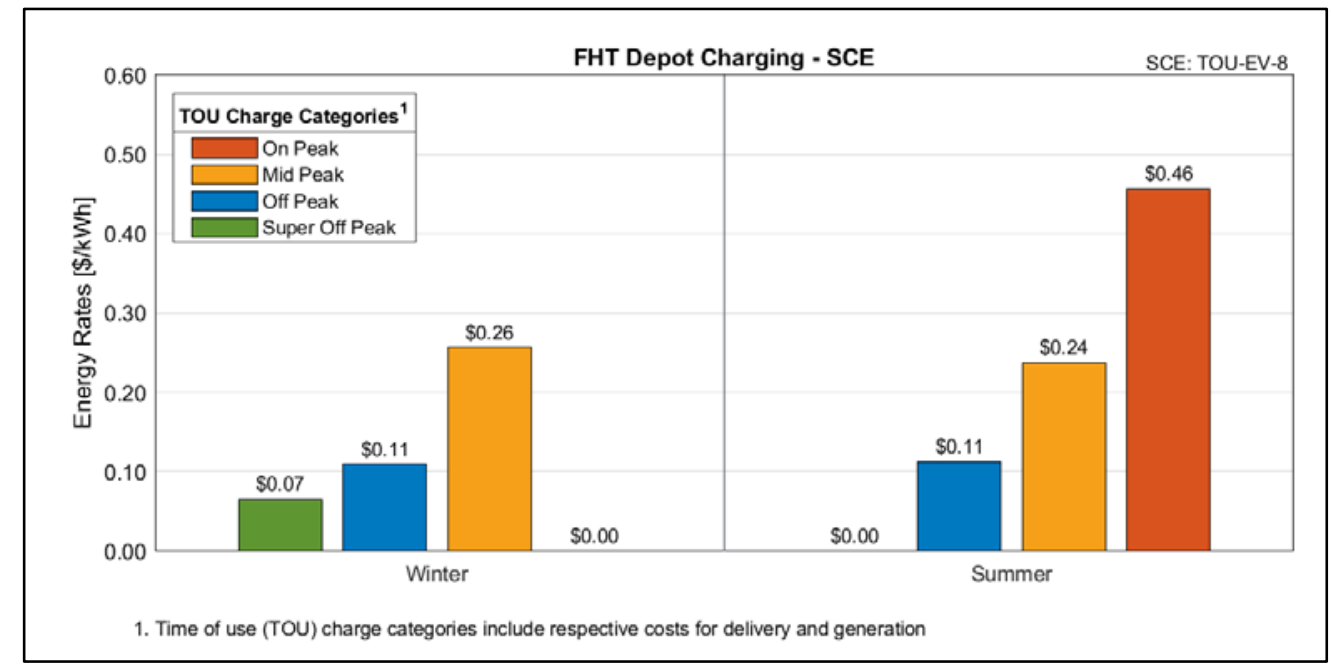

Figure 56. Average TOU electricity consumption rates for Arcadia depot charging

The monthly average unit cost of electricity $(\$ / \mathrm{kWh})$ for the Arcadia charging station is shown in Figure 57, separated by cost category. Most depot charging occurs during Off-Peak (overnight) time periods, yet the limited On-Peak charging during summer months accounts for a significant portion of the utility bills for those months. Figure 58 shows a similar chart for the electricity costs at the AITC charging station. This station is governed by Azusa Light \& Water, and the rate schedule applied by the utility uses TOU charges and demand charges. The TOU cost categories for Azusa Light \& Water are not the same as those prescribed by SCE, but they function similarly. Demand charges are a significant factor in the electricity costs for the supplemental on-route charging provided by the AITC charging station. 


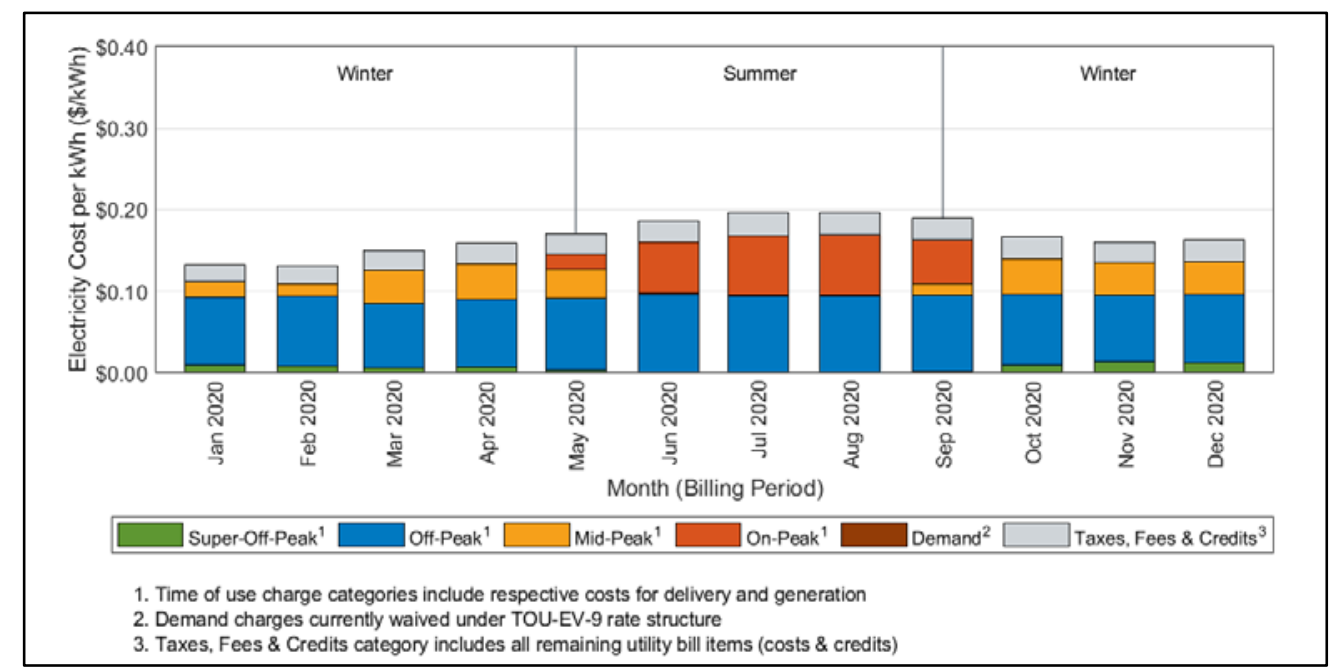

Figure 57. Monthly electricity costs for Arcadia depot charging

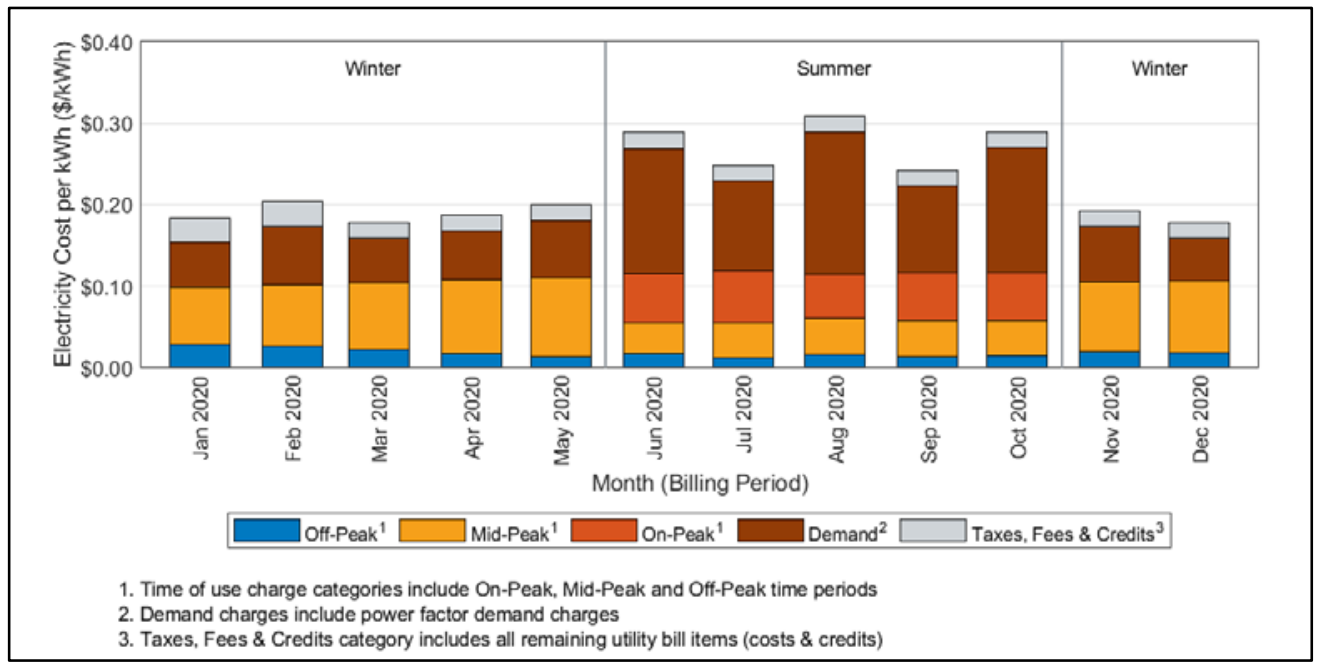

Figure 58. Monthly electricity costs for AITC fast charging

Figure 59 shows the total monthly energy used to charge the BEB fleet from the Arcadia and AITC charging stations. The Arcadia station accounts for $55 \%-70 \%$ of the fleet charging energy each month. 


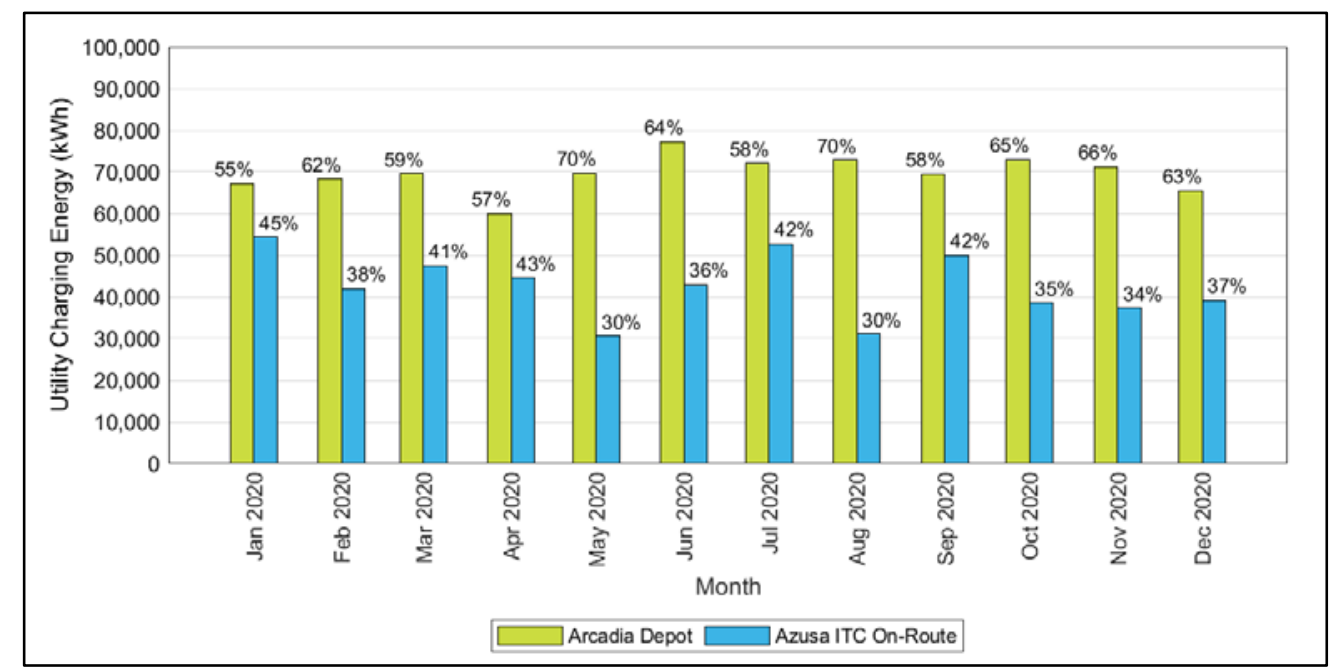

Figure 59. Monthly electricity consumption for Arcadia depot and AITC charging

Table 23 shows the average electricity price for each charging station as well as combined seasonal averages. For Arcadia, the 2020 average was $\$ 0.17$ per $\mathrm{kWh}$ and for AITC, the average was $\$ 0.22$ per $\mathrm{kWh}$. Coincidentally, the winter and summer averages are $\$ 0.17$ per $\mathrm{kWh}$ and $\$ 0.22$ per kWh, respectively. Overall, the average electricity price for the BEB fleets at Arcadia was $\$ 0.19$ per $\mathrm{kWh}$, which corresponds to a diesel-equivalent fuel price of $\$ 7.07$ per dge.

Table 23. Average Electricity Price for the Arcadia BEB Fleets

\begin{tabular}{|c|c|c|c|c|c|}
$\begin{array}{c}\text { Average } \\
\begin{array}{c}\text { Electricity } \\
\text { Price }\end{array}\end{array}$ & $\begin{array}{c}\text { Arcadia Depot } \\
\text { Charging }\end{array}$ & $\begin{array}{c}\text { AlTC On- } \\
\text { Route } \\
\text { Charging }\end{array}$ & $\begin{array}{c}\text { Overall } \\
\text { Average }\end{array}$ & $\begin{array}{c}\text { Summer } \\
\text { Average } \\
\text { (June-Sept.) }\end{array}$ & $\begin{array}{c}\text { Winter } \\
\text { Average } \\
\text { (Oct-May) }\end{array}$ \\
\hline \$/kWh & 0.17 & 0.22 & 0.19 & 0.22 & 0.17 \\
\hline \$/dge & 6.29 & 8.37 & 7.07 & 7.90 & 6.08 \\
\hline
\end{tabular}

Foothill Transit's CNG buses at Arcadia are also fueled once each day. NREL analyzed fueling records for the $\mathrm{CNG}$ buses to calculate the average monthly fuel price, which includes the CNG commodity cost and O\&M costs (Figure 60). The average fuel price during 2020 was $\$ 1.46$ per dge, less than $25 \%$ of the average electricity price ( $\$ 7.07$ per dge). In addition, the CNG price is more consistent throughout the year. Figure 61 compares the monthly average price of electricity and $\mathrm{CNG}$ fuel on an energy-equivalent basis. 


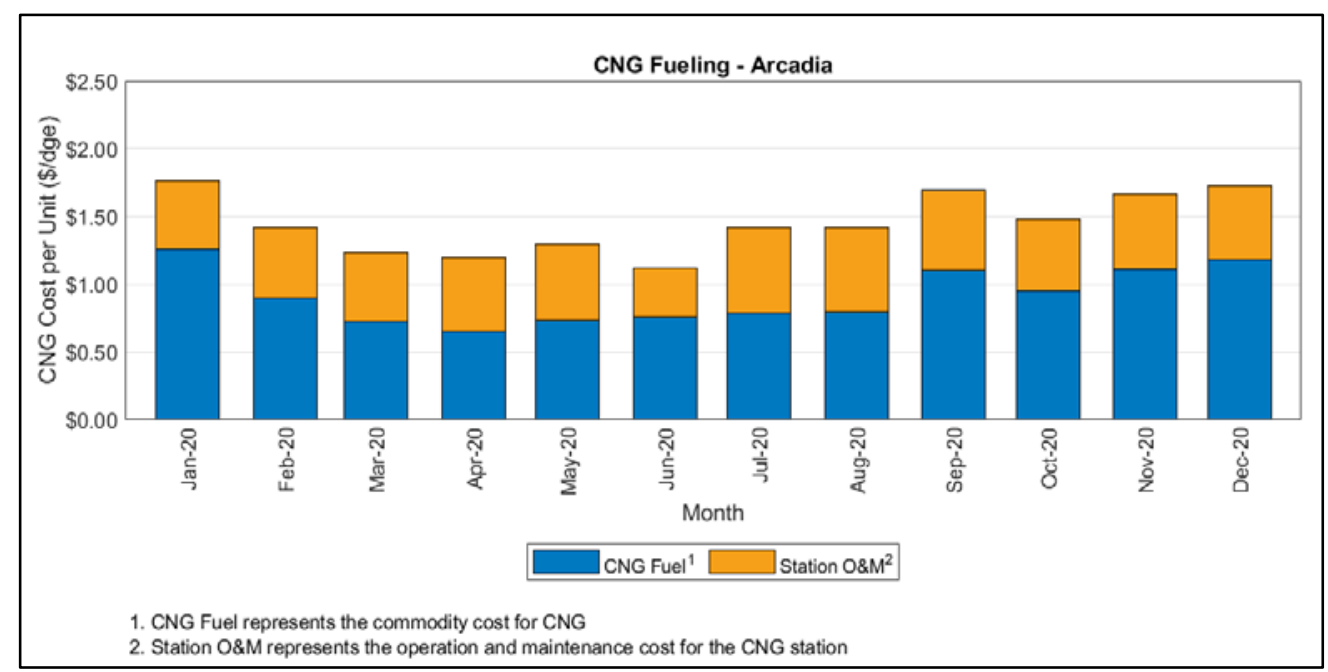

Figure 60. Monthly average CNG price for Arcadia

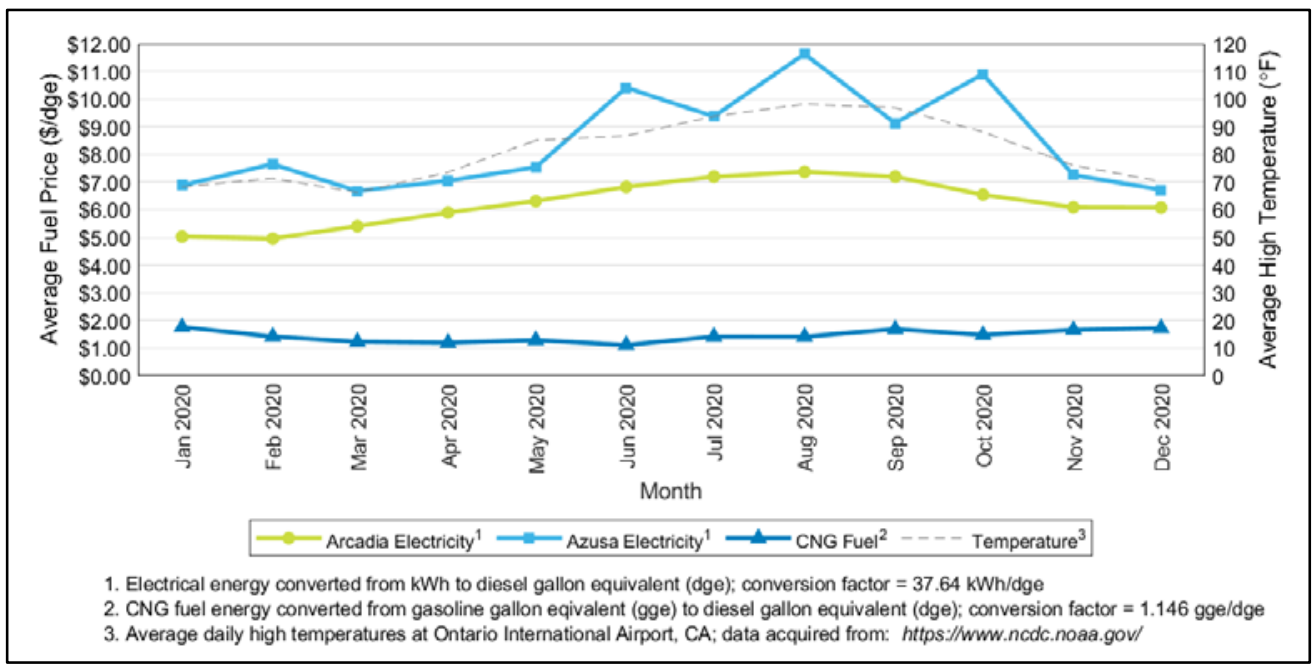

Figure 61. Monthly average fuel price for the BEBs and CNG fleets

Figure 62 shows the monthly average fuel cost per mile for the BEBs and CNG buses at Arcadia, as well as the monthly average high temperature. The higher fuel economy for the BEBs and the higher electricity price for the BEBs offset each other, resulting in a similar fuel cost per mile for the BEBs compared to the CNG fleet, especially during winter months. The 2020 average fuel cost per mile was $\$ 0.42$ per mile for the BEB fleet and $\$ 0.37$ per mile for the CNG fleet. 


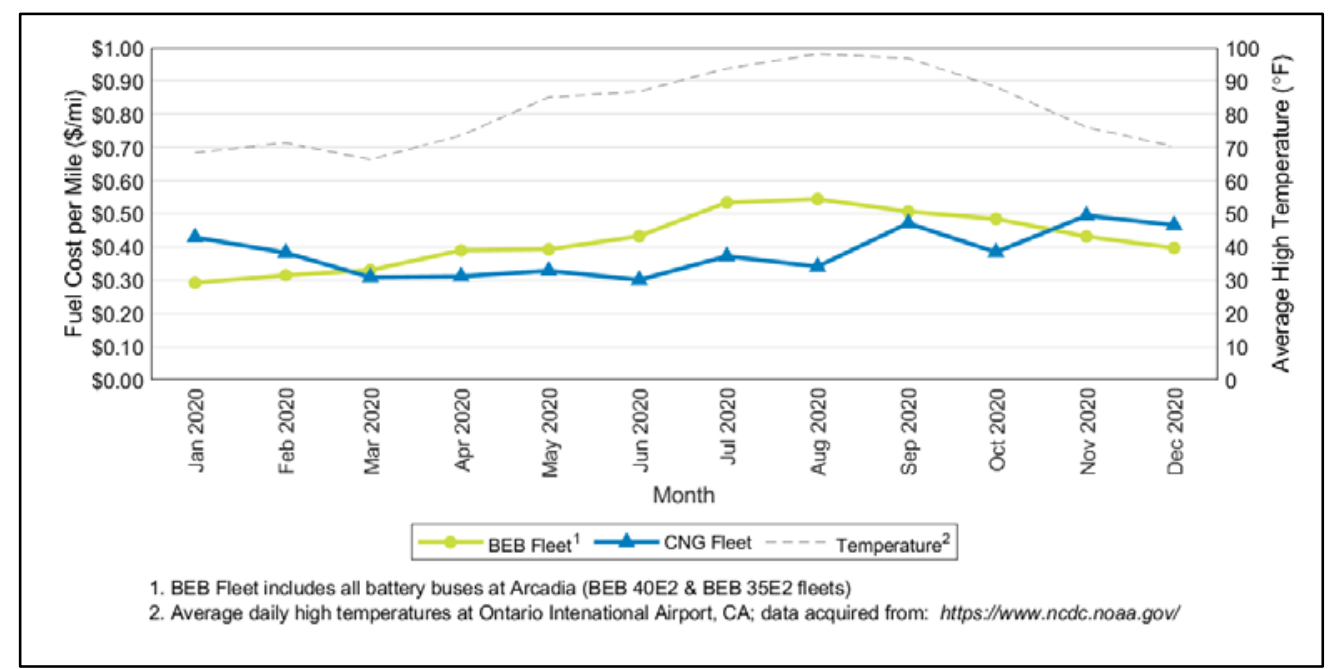

Figure 62. Monthly average fuel cost per mile for the BEB and CNG fleets

\subsection{Roadcall Analysis}

Table 11 provides the MBRC for the BEBs and CNG buses categorized by general bus roadcalls, propulsion-related roadcalls, and ESS-related roadcalls. To date, the BEB 40E2 fleet has not had an ESS-related roadcall. This roadcall analysis includes data accumulated since the clean point of January 2020. Since the beginning of the data period, the BEB 40E2 fleet has total bus MBRC and propulsion-related MBRC similar to that of the CNG fleet.

Table 24. Roadcalls and MBRC

\begin{tabular}{|l|c|c|}
\hline \multicolumn{2}{|c|}{ BEB 40E2 } & CNG \\
\hline Dates & $1 / 2020-12 / 2020$ & $1 / 2020-12 / 2020$ \\
\hline Total miles accumulated & 507,619 & 787,353 \\
\hline Average miles accumulated per bus & 36,258 & 56,240 \\
\hline Bus roadcalls & 22 & 32 \\
\hline Bus MBRC & 23,074 & 24,605 \\
\hline Propulsion-related roadcalls & 15 & 25 \\
\hline Propulsion-related MBRC & 33,841 & 31,494 \\
\hline ESS-related roadcalls & 0 & - \\
\hline ESS-related MBRC & - & - \\
\hline
\end{tabular}

Figure 63 presents the cumulative MBRC by category for the BEB 40E2 and CNG fleets. The ultimate target for bus MBRC (4,000) is included in the upper plot of Figure 63 as a red dashed line. 


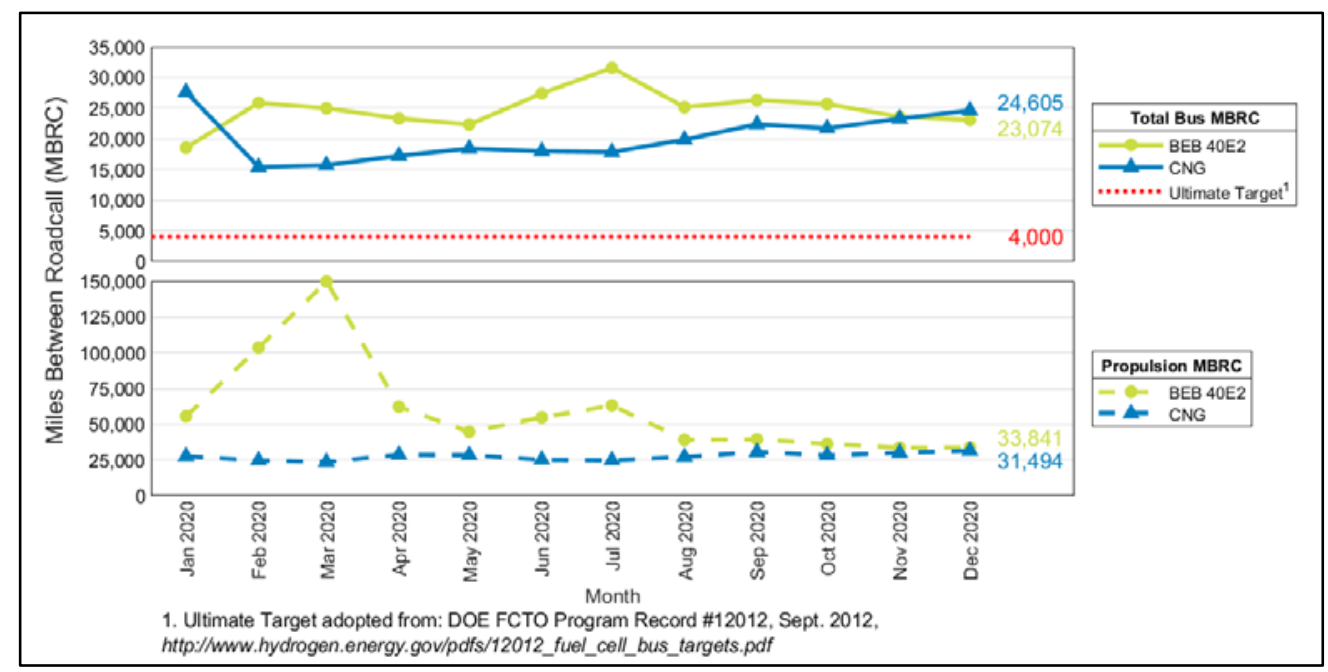

Figure 63. Cumulative MBRC, BEB 40E2 and CNG fleets

\subsection{Maintenance Analysis}

NREL evaluated the maintenance costs for the Arcadia buses using the same protocol as that of Pomona. This section first covers total maintenance costs and then maintenance costs by bus system. The BEB 40E2 fleet is still under warranty. Foothill Transit contractor staff handle PMI and general bus work. Transit staff also handle most of the warranty work with help from Proterra technicians as needed. The agency is reimbursed by Proterra for warranty-covered parts and some labor. This has remained constant throughout the data period.

\subsubsection{Total Work Order Maintenance Costs}

Total maintenance costs include the cost of parts and labor rates at $\$ 50$ per hour. Table 25 and Table 26 show total maintenance costs for the BEB 40E2 and CNG fleets, respectively. Scheduled and unscheduled maintenance cost per mile is provided for each bus individually and for each fleet. During the reporting period, the BEB 40E2 fleet had a maintenance cost per mile that was very similar to that of the CNG buses. 
Table 25. Total Work Order Maintenance Costs, BEB 40E2 Fleet

\begin{tabular}{|c|c|c|c|c|c|c|}
\hline Bus ID & Miles & \multicolumn{2}{c}{$\begin{array}{c}\text { Parts } \\
\text { Cost (\$) }\end{array}$} & \multicolumn{2}{c}{ Labor } & \multicolumn{2}{c}{$\begin{array}{c}\text { Scheduled Cost } \\
\text { per Mile (\$) }\end{array}$} & $\begin{array}{c}\text { Unscheduled } \\
\text { Cost per Mile (\$) }\end{array}$ & $\begin{array}{c}\text { Total Cost } \\
\text { per Mile (\$) }\end{array}$ \\
\hline 2600 & 26,752 & $3,479.92$ & 148.9 & 0.09 & 0.32 & 0.41 \\
\hline 2601 & 33,025 & $6,648.08$ & 214.0 & 0.06 & 0.47 & 0.53 \\
\hline 2602 & 41,890 & $4,665.60$ & 170.3 & 0.07 & 0.25 & 0.31 \\
\hline 2603 & 35,966 & $4,261.39$ & 173.5 & 0.07 & 0.29 & 0.36 \\
\hline 2604 & 37,787 & $2,651.14$ & 160.1 & 0.07 & 0.21 & 0.28 \\
\hline 2605 & 41,464 & $3,755.66$ & 167.4 & 0.07 & 0.22 & 0.29 \\
\hline 2606 & 42,174 & $2,932.50$ & 198.9 & 0.07 & 0.24 & 0.31 \\
\hline 2607 & 44,245 & $4,527.58$ & 168.9 & 0.08 & 0.21 & 0.29 \\
\hline 2608 & 17,439 & 921.97 & 119.9 & 0.08 & 0.32 & 0.40 \\
\hline 2609 & 38,874 & $8,600.56$ & 224.5 & 0.08 & 0.43 & 0.51 \\
\hline 2610 & 43,898 & $3,946.34$ & 146.9 & 0.07 & 0.19 & 0.26 \\
\hline 2611 & 26,146 & $5,256.91$ & 223.5 & 0.08 & 0.55 & 0.63 \\
\hline 2612 & 42,792 & $4,710.63$ & 163.4 & 0.05 & 0.25 & 0.30 \\
\hline 2613 & 35,161 & $5,035.95$ & 186.0 & 0.07 & 0.34 & 0.41 \\
\hline BEB 40E2 & $\mathbf{5 0 7 , 6 1 5}$ & $\mathbf{6 1 , 3 9 4 . 2 3}$ & $\mathbf{2 , 4 6 6 . 0}$ & $\mathbf{0 . 0 7}$ & $\mathbf{0 . 2 9}$ & 0.36 \\
\hline Fleet & & & & & & 0.36 \\
\hline
\end{tabular}

Table 26. Total Work Order Maintenance Costs, CNG Fleet

\begin{tabular}{|c|c|c|c|c|c|c|}
\hline Bus ID & Miles & $\begin{array}{l}\text { Parts Cost } \\
\text { (\$) }\end{array}$ & $\begin{array}{l}\text { Labor } \\
\text { Hours }\end{array}$ & $\begin{array}{c}\text { Scheduled Cost } \\
\text { per Mile (\$) }\end{array}$ & $\begin{array}{l}\text { Unscheduled } \\
\text { Cost per Mile (\$) }\end{array}$ & $\begin{array}{l}\text { Total Cost } \\
\text { per Mile (\$) }\end{array}$ \\
\hline 2516 & 56,174 & $7,669.11$ & 245.4 & 0.12 & 0.24 & 0.35 \\
\hline 2517 & 55,099 & $8,628.15$ & 246.6 & 0.12 & 0.26 & 0.38 \\
\hline 2518 & 58,050 & $15,809.87$ & 240.4 & 0.11 & 0.37 & 0.48 \\
\hline 2519 & 56,001 & $8,944.95$ & 235.9 & 0.11 & 0.26 & 0.37 \\
\hline 2520 & 58,689 & $4,833.69$ & 187.4 & 0.11 & 0.13 & 0.24 \\
\hline 2521 & 55,922 & $7,564.90$ & 205.6 & 0.11 & 0.21 & 0.32 \\
\hline 2522 & 54,927 & $8,048.92$ & 261.7 & 0.11 & 0.27 & 0.38 \\
\hline 2523 & 59,062 & $8,367.98$ & 208.7 & 0.11 & 0.21 & 0.32 \\
\hline 2524 & 58,892 & $7,492.21$ & 212.6 & 0.12 & 0.19 & 0.31 \\
\hline 2525 & 55,152 & $10,656.36$ & 239.7 & 0.13 & 0.28 & 0.41 \\
\hline 2526 & 51,322 & $10,298.55$ & 226.1 & 0.12 & 0.30 & 0.42 \\
\hline 2527 & 57,458 & $10,222.16$ & 227.0 & 0.12 & 0.25 & 0.38 \\
\hline 2528 & 57,958 & $6,367.73$ & 224.3 & 0.13 & 0.17 & 0.30 \\
\hline 2529 & 52,647 & $4,807.15$ & 218.6 & 0.12 & 0.17 & 0.30 \\
\hline CNG Fleet & 787,353 & $119,711.72$ & 3,180 & 0.12 & 0.24 & 0.35 \\
\hline
\end{tabular}

\subsubsection{Monthly Maintenance Cost Comparison}

This section presents the monthly maintenance cost for each fleet for the entire data period. To understand what factors are driving costs, NREL analyses the data multiple ways-looking at scheduled vs. unscheduled costs, parts vs. labor costs, and costs by vehicle system and subsystem. Figure 64 provides the total monthly maintenance cost for the BEB 40E2 and CNG bus fleets. The monthly cost for the propulsion system is also included for each fleet as dashed lines. 


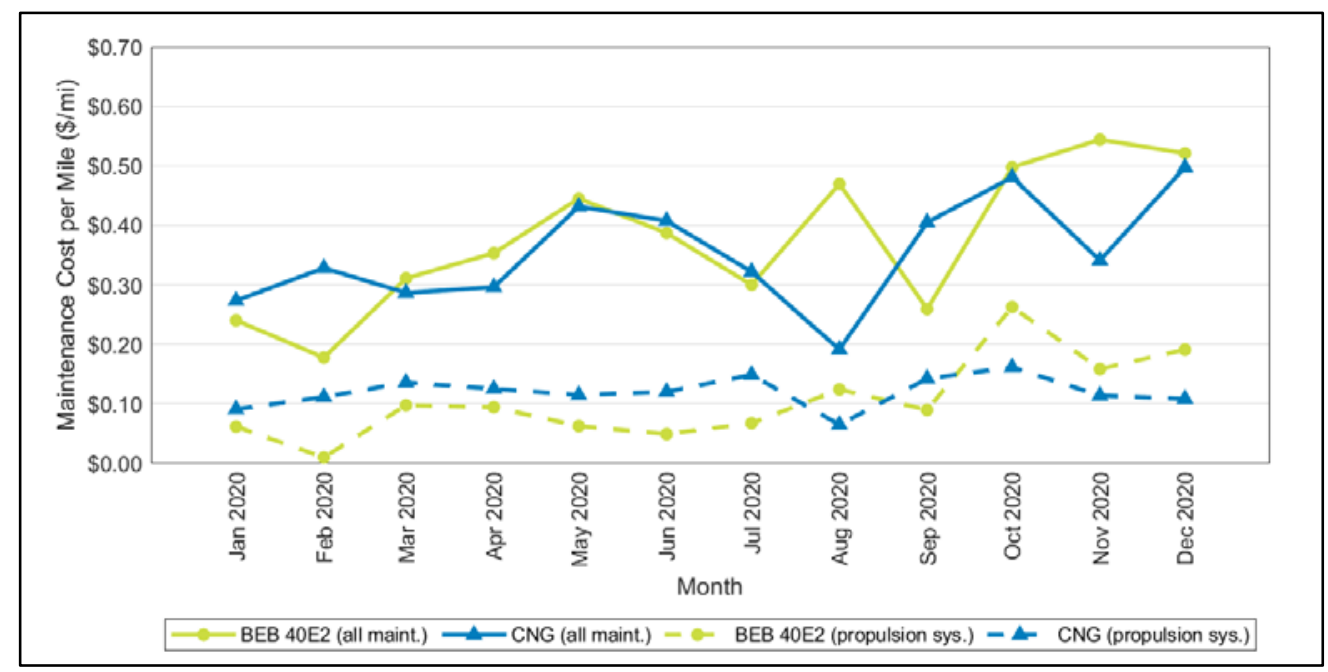

Figure 64. Monthly maintenance costs per mile, BEB 40E2 and CNG fleets

The monthly scheduled and unscheduled maintenance cost per mile for the BEB 40E2 and CNG fleets are shown as stacked columns in Figure 65 and Figure 66, respectively. Scheduled maintenance for the BEB 40E2 buses was consistent over the data period. For most months, eight out of the 13 BEBs reached a mileage for a minor preventive maintenance, which consists of safety inspections and changeout of several filters. The CNG buses typically have higher scheduled maintenance costs per mile than the BEBs and lower unscheduled costs per mile. Scheduled maintenance for the CNG buses consists of safety inspections, routine oil and filter replacements, and tune-ups.

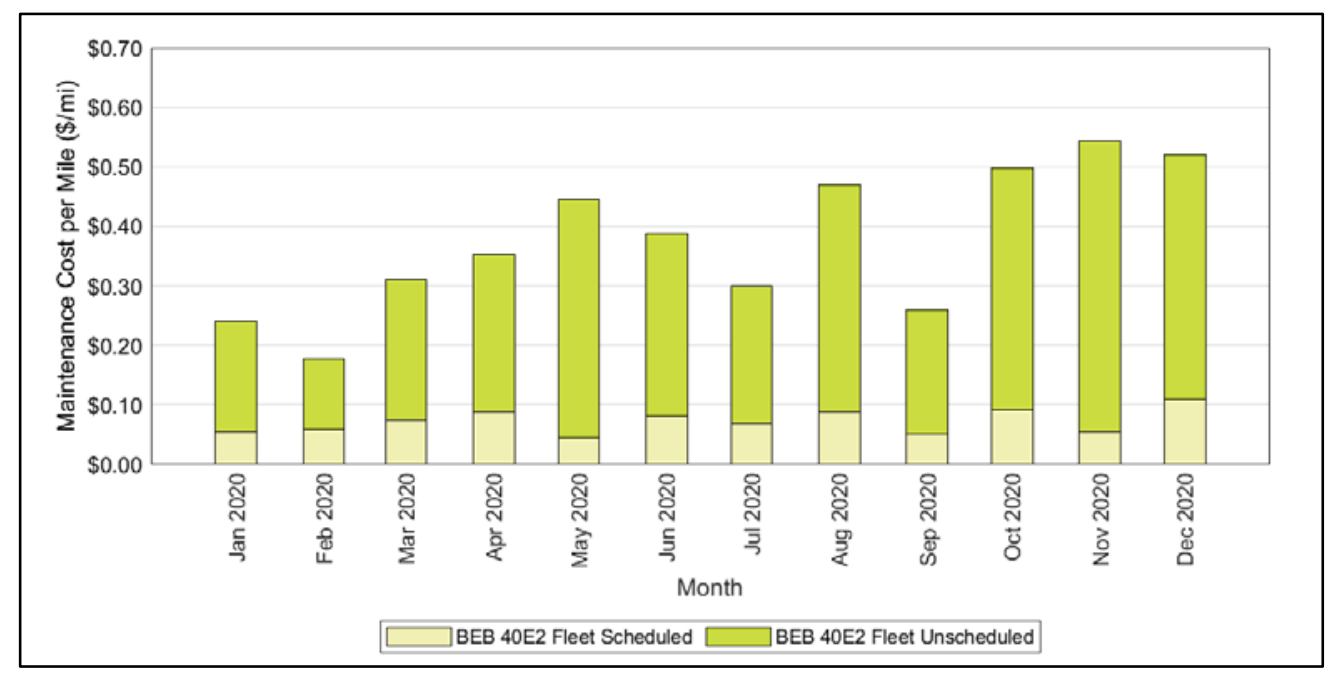

Figure 65. Monthly scheduled and unscheduled maintenance costs per mile, BEB 40E2 fleet 


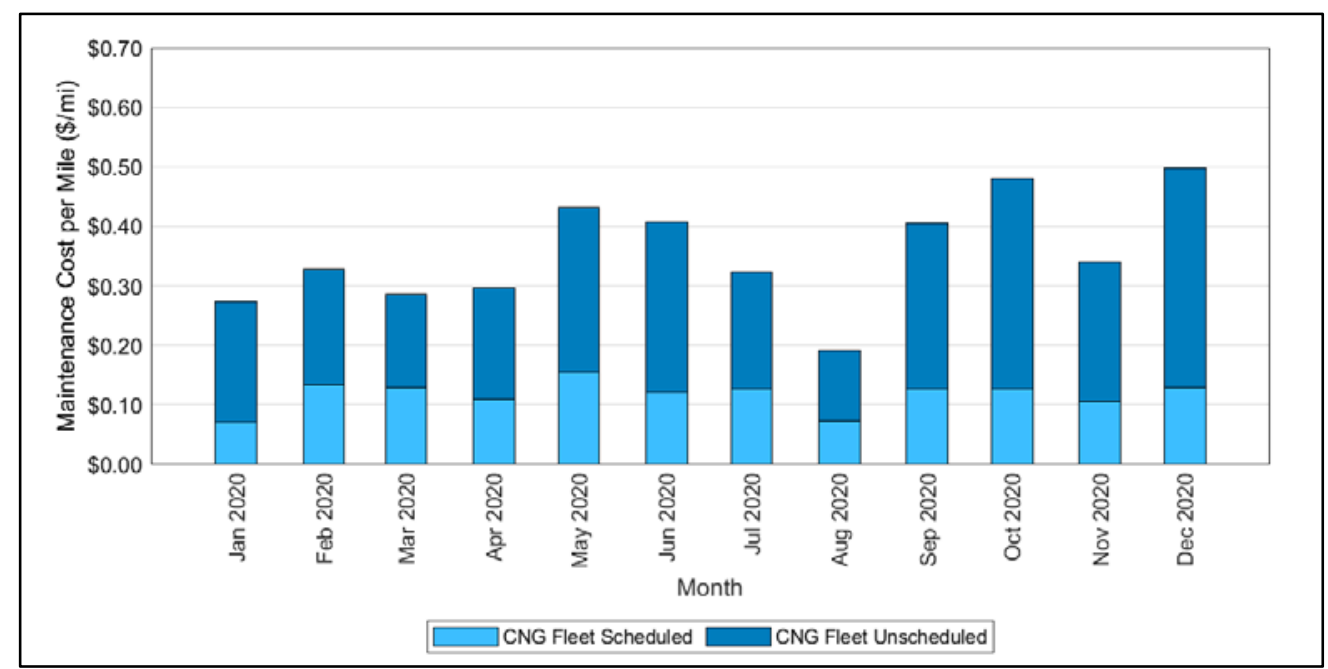

Figure 66. Monthly scheduled and unscheduled maintenance costs per mile, CNG fleet

Figure 67 and Figure 68 present the same data for the two fleets separated by parts and labor cost per mile. For the BEB 40E2 fleet, labor costs make up $67 \%$ of the total costs. While most of the major repairs for the BEB 40E2 fleet are being handled by the OEM under warranty, transit staff sometimes spend time troubleshooting an issue prior to that time. As transit staff become more familiar with the BEBs and systems, labor hours are expected to decrease. For the CNG fleet, labor costs are $57 \%$ of total costs.

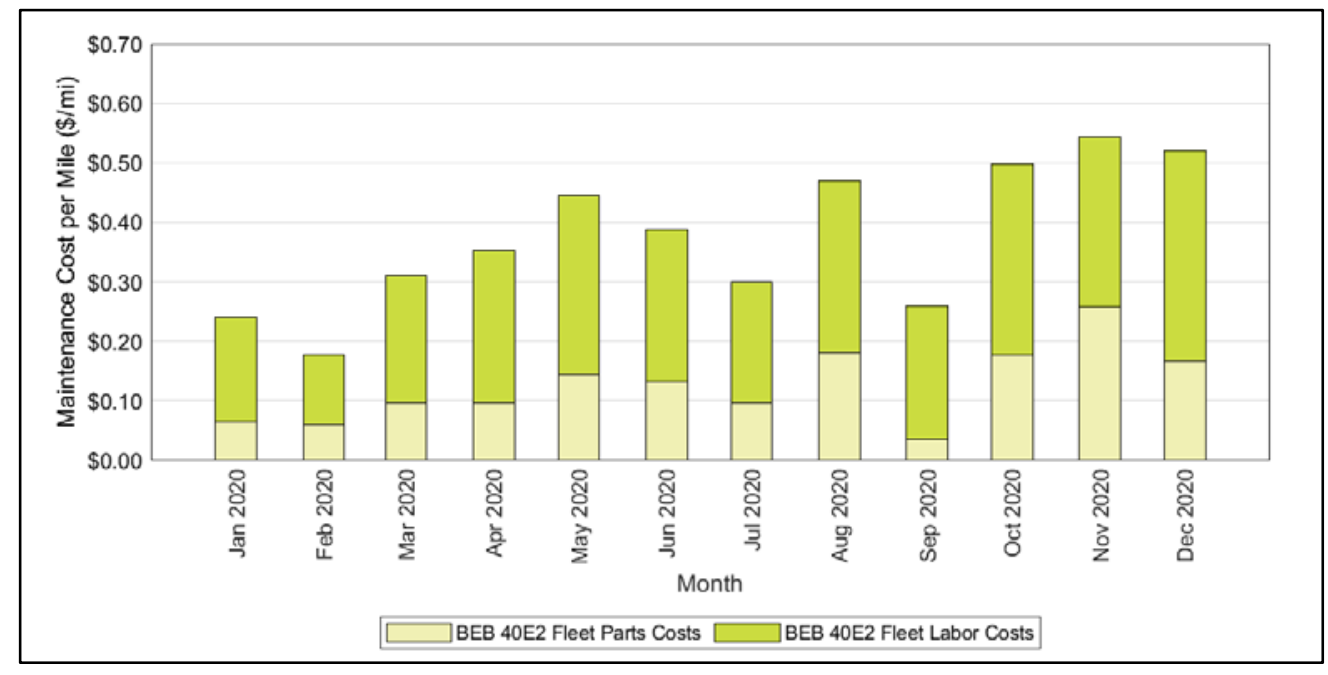

Figure 67. Monthly parts and labor maintenance costs per mile, BEB 40E2 fleet 


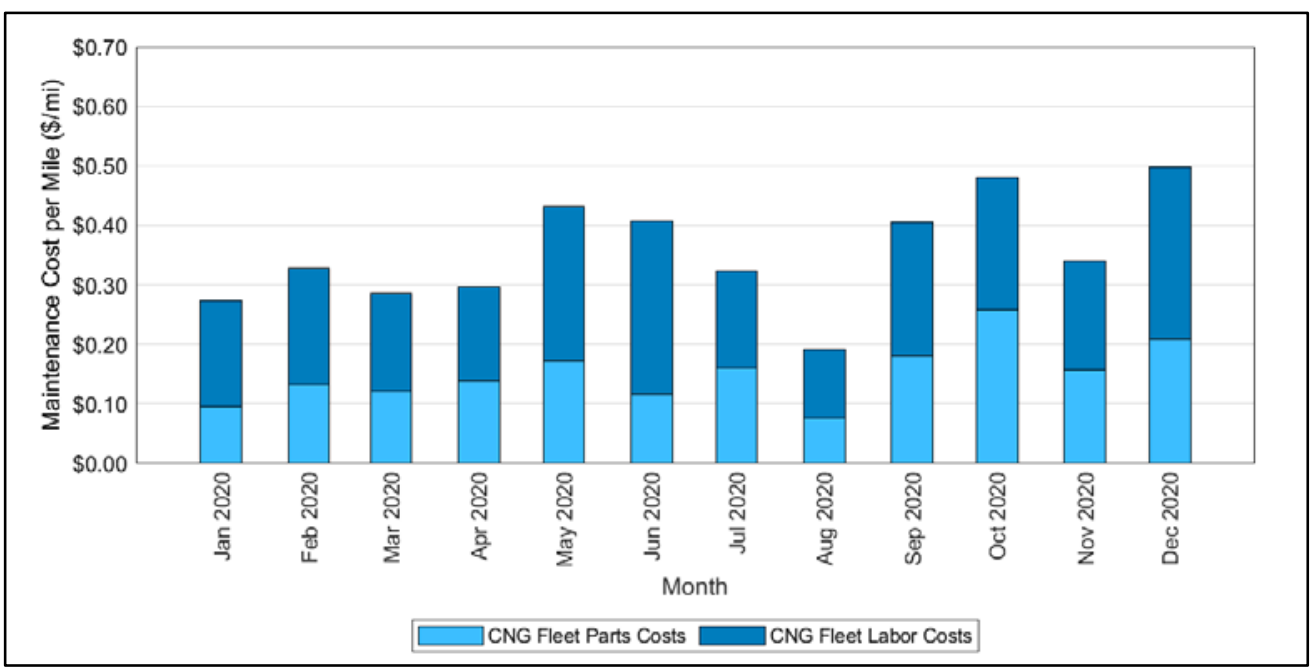

Figure 68. Monthly parts and labor maintenance costs per mile, CNG fleet

\subsubsection{Work Order Maintenance Costs Categorized by System}

Table 27 shows maintenance costs by vehicle system and bus fleet (without warranty costs). The color shading denotes the systems with the highest percentage of maintenance costs: orange for the highest, green for the second highest, and purple for the third highest. The top three systems with the highest percentage of maintenance costs for the BEB 40E2 fleet and the CNG fleet were the same (in order from highest to lowest): (1) propulsion-related; (2) PMI; and (3) cab, body, and accessories.

Table 27. Maintenance Cost per Mile by Vehicle System

\begin{tabular}{|l|c|c|c|c|}
\multicolumn{1}{|c|}{ Vehicle System } & \multicolumn{2}{c}{ BEB 40E2 Fleet } & \multicolumn{2}{c|}{ CNG Fleet } \\
& $\begin{array}{c}\text { Cost per } \\
\text { Mile (\$) }\end{array}$ & $\begin{array}{c}\text { Percent of } \\
\text { Total }(\%)\end{array}$ & $\begin{array}{c}\text { Cost per } \\
\text { Mile (\$) }\end{array}$ & $\begin{array}{c}\text { Percent of } \\
\text { Total (\%) }\end{array}$ \\
\hline Propulsion-related & 0.101 & 27.8 & 0.120 & 34.0 \\
\hline Cab, body, and accessories & 0.065 & 17.7 & 0.046 & 12.9 \\
\hline PMI & 0.067 & 18.4 & 0.065 & 18.4 \\
\hline Brakes & 0.004 & 1.1 & 0.019 & 5.4 \\
\hline Frame, steering, and suspension & 0.010 & 2.6 & 0.036 & 10.3 \\
\hline HVAC & 0.014 & 3.8 & 0.015 & 4.3 \\
\hline Lighting & 0.010 & 2.8 & 0.007 & 2.0 \\
\hline Air, general & 0.004 & 1.1 & 0.002 & 0.4 \\
\hline Axles, wheels, and drive shaft & 0.026 & 7.2 & 0.007 & 1.9 \\
\hline Tires & 0.063 & 17.4 & 0.037 & 10.4 \\
\hline Towing charges & 0.000 & 0.0 & 0.000 & 0.0 \\
\hline Total & $\mathbf{0 . 3 6 4}$ & $\mathbf{1 0 0}$ & $\mathbf{0 . 3 5 4}$ & 100 \\
\hline
\end{tabular}

Figure 69 shows the monthly maintenance cost per mile by vehicle system for the BEB 40 E2 fleet. The high costs in May for cab, body, and accessories were primarily for information technology equipment. Higher propulsion system costs in October, November, and December were for replacing low-voltage batteries and labor for troubleshooting issues with the cooling system and high-voltage systems. Figure 70 presents equivalent data for the $\mathrm{CNG}$ buses. 


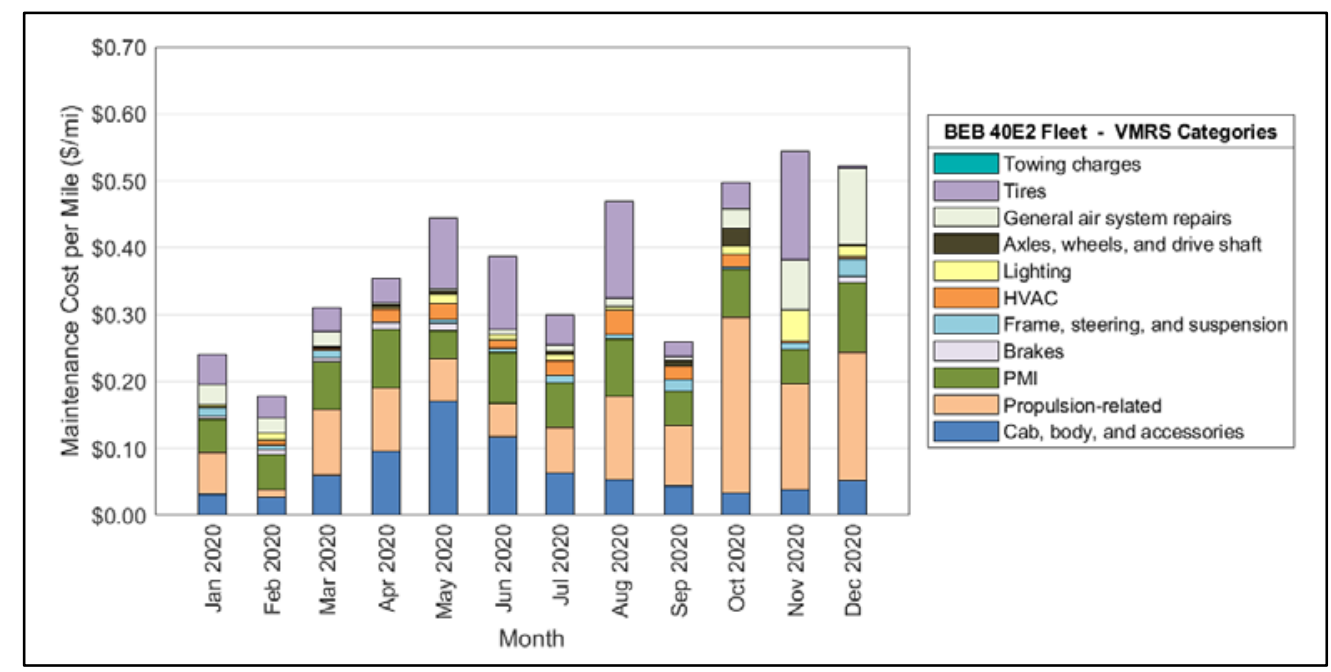

Figure 69. Monthly maintenance cost per mile by vehicle system, BEB 40E2 fleet

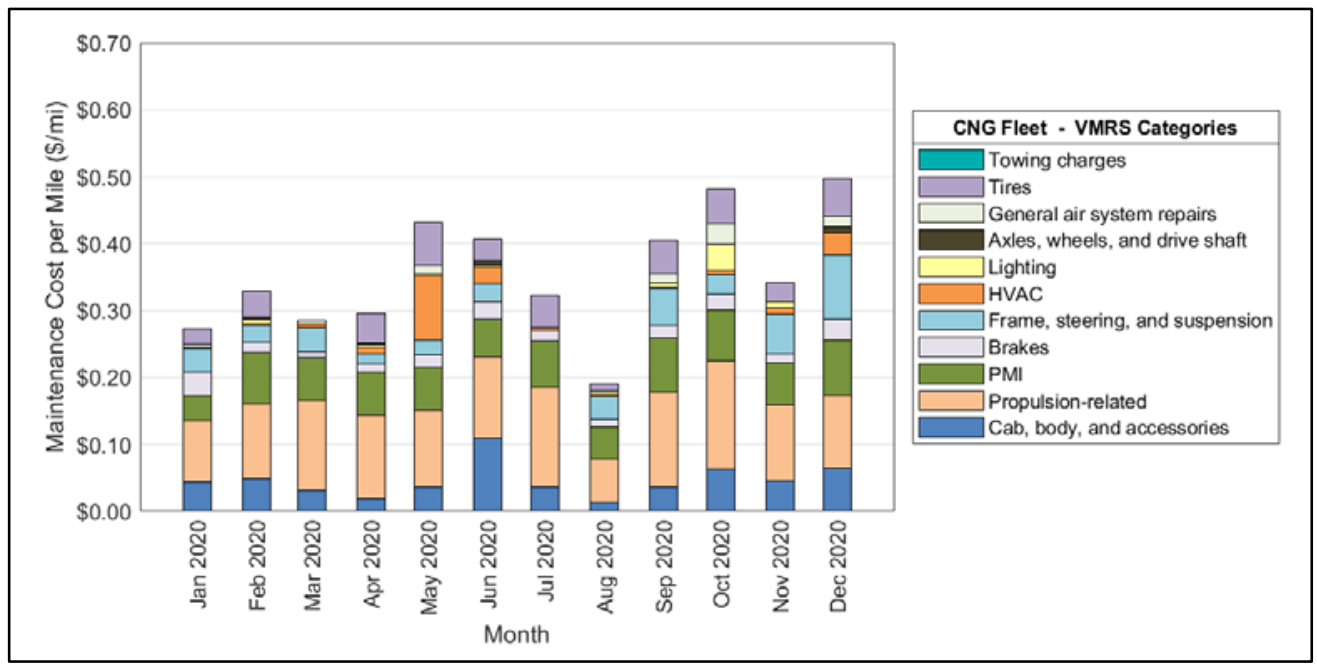

Figure 70. Monthly maintenance cost per mile by vehicle system, CNG fleet

\subsubsection{Propulsion-Related Work Order Maintenance Costs}

Table 28 shows the propulsion-related system maintenance by category. During the data period, the propulsion-related maintenance costs for the BEB 40E2 fleet were 16\% lower than that of the CNG buses. Items contributing to costs for the BEB 40E2 fleet were low-voltage batteries (cranking/charging category) and labor hours for troubleshooting systems such as cooling and high-voltage wiring. Parts costs for the $\mathrm{CNG}$ buses were the primary contributor to propulsion subsystem costs. High-cost CNG parts included an electronic control module, an exhaust gas recirculation cooler, low-voltage batteries, spark plugs, water pumps, high-pressure regulators, and air valves. 
Table 28. Propulsion-Related Maintenance Costs by Subsystem $(\$ / \mathrm{mi})$

\begin{tabular}{|l|c|c|}
\multicolumn{1}{|c}{ Propulsion System Maintenance Costs } & BEB 40E2 & CNG \\
\hline Exhaust system & 0.000 & 0.007 \\
\hline Fuel system & 0.000 & 0.019 \\
\hline Power plant system (battery system or CNG engine) & 0.008 & 0.032 \\
\hline Electric drive and motor & 0.019 & 0.000 \\
\hline $\begin{array}{l}\text { Non-lighting electrical system (general electrical, } \\
\text { charging, cranking, ignition) }\end{array}$ & 0.037 & 0.035 \\
\hline Air intake system & 0.000 & 0.004 \\
\hline Cooling system & 0.026 & 0.020 \\
\hline Transmission system & 0.010 & 0.004 \\
\hline Hydraulic system & 0.000 & 0.000 \\
\hline Total propulsion-related system maintenance & 0.101 & 0.120 \\
\hline
\end{tabular}

Figure 71 and Figure 72 show the monthly propulsion-related cost by subsystem for the BEB 40E2 fleet and CNG fleet, respectively. The cranking/charging category includes costs for replacing low-voltage batteries. Both fleets had these batteries replaced during the evaluation period. The cooling system costs for the BEB 40E2 fleet were primarily for labor to troubleshoot the problem with cooling pumps; the parts for the actual repair were covered under warranty.

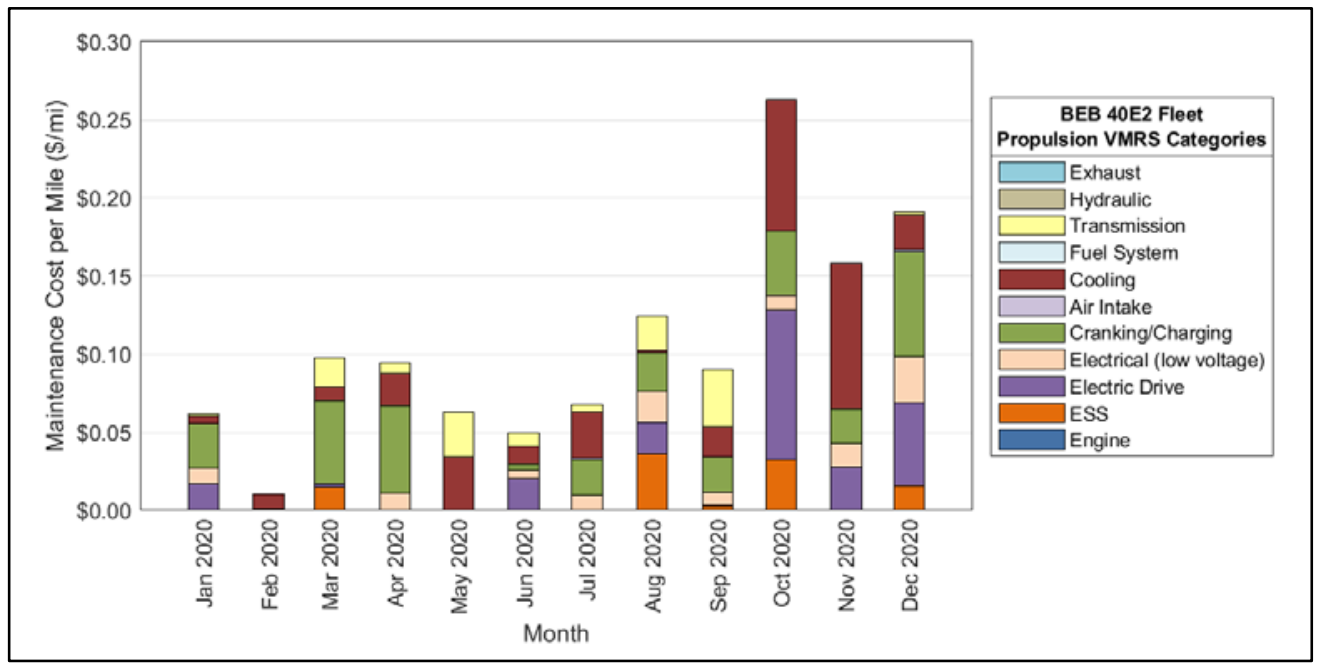

Figure 71. Monthly maintenance cost per mile by propulsion subsystem, BEB 40E2 fleet 


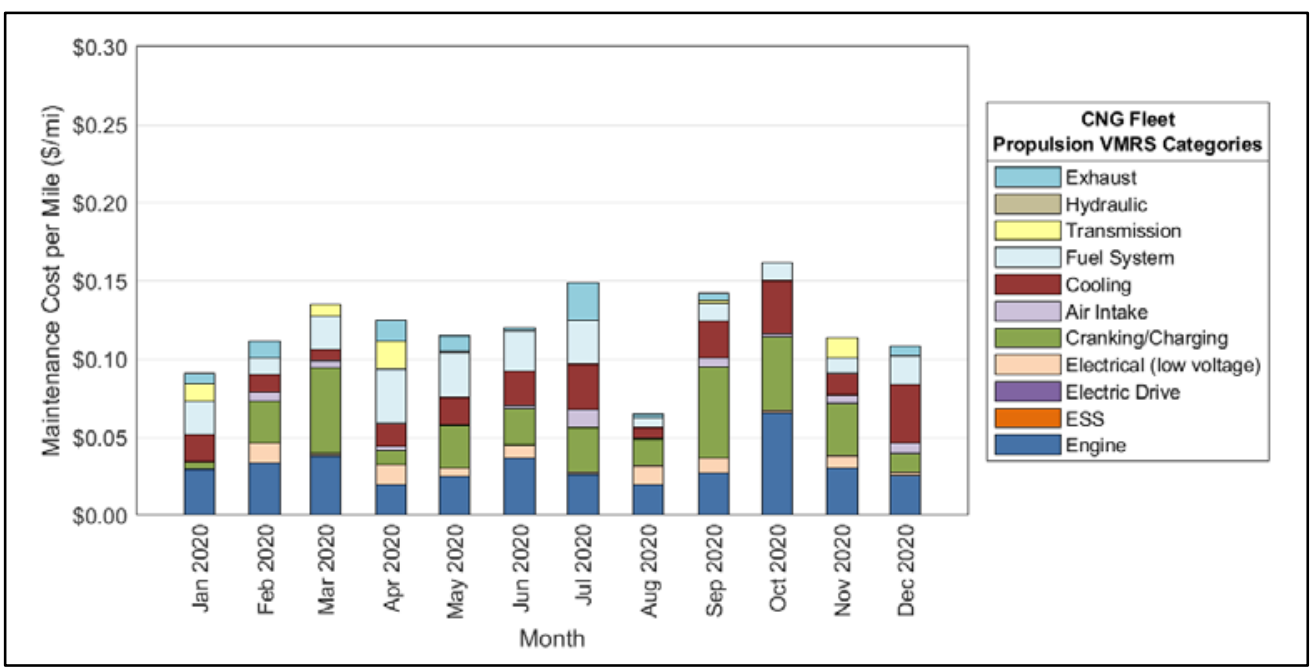

Figure 72. Monthly maintenance cost per mile by propulsion subsystem, CNG fleet

\subsubsection{Summary of Maintenance Issues}

The BEB 40E2 fleet has been in service for a full year and is still under warranty. Foothill Transit has experienced several issues with the fleet, most of which were covered under warranty. This section outlines the primary issues encountered.

Coolant pump failure-The coolant pumps on several of the BEB 40E2 buses developed cracks, resulting in leaks. The OEM determined the pumps had quality issues and replaced all under warranty.

DC-DC converter-For one bus, a DC-DC converter failed and was replaced under warranty.

Air compressor issue - The air compressors on several buses developed leaks and were replaced under warranty.

Low-voltage batteries-Like the fast-charge BEBs at Pomona, the BEB 40E2 fleet had lowvoltage battery failures. The BEBs have two low-voltage batteries, whereas the CNG buses have four. The BEB fleet had low-voltage batteries changed out 21 times compared to 11 times for the CNG baseline fleet. This equates to 4.1 changeouts per 100,000 miles for the BEB fleet and 1.4 changeouts per 100,000 miles for the CNG fleet. On a cost basis, the low-voltage battery replacements cost $\$ 0.02$ per mile for the BEBs and $\$ 0.01$ per mile for the CNG buses.

Tire wear-The BEB 40E2 fleet experience higher tire wear compared to the CNG buses. Tire cost made up $17 \%$ of the maintenance cost for the BEB 40E2 fleet. Since the BEBs went into service, Foothill Transit has replaced 83 tires with an average cost per bus of $\$ 2,472$ (parts plus labor). Tire costs for the $\mathrm{CNG}$ buses made up $10 \%$ of the maintenance costs during the data period. The agency replaced 74 tires with an average per-bus cost of $\$ 2,238$. When taking mileage into account, the BEBs travel an average of 6,116 miles per tire and have a cost of $\$ 0.06$ per mile. The CNG buses travel 10,640 miles per tire and have a cost of $\$ 0.04$ per mile. 


\section{Summary of Achievements and Challenges}

This section focuses on the achievements and challenges for Foothill Transit and its partners in implementing BEBs into their transit operations. As with all new technology development and deployment, lessons learned during this project can aid other agencies considering BEB technology. Advanced technology demonstrations typically experience new and sometimes unique challenges that need to be resolved to continue advancing the state of the technology. As the technology matures, improved costs and operational effectiveness enable more agencies to implement the technology.

Foothill Transit was an early adopter of BEB technology, deploying one of the first fleets of BEBs in larger numbers than previous demonstrations. This early demonstration was valuable to help the OEM identify issues, develop solutions, and make design improvements for the nextgeneration buses. However, early-adopter agencies also take on added risk and cost during these demonstrations.

Since being placed in service in April 2014, the BEB 35FC fleet has operated more than 1.77 million miles. At 6 years, the BEB 35FC fleet has now reached the middle of expected life and is showing signs of age. Foothill Transit reports that the fleet has experienced problems with bus bodies and other bus components. This section summarizes the primary challenges experienced by Foothill Transit during the evaluation.

BEB range - Foothill Transit reports that, despite implementing new extended-range BEBs, it still has range limitations because the current BEB technology cannot meet all its service blocks. Some planned blocks include interlines between multiple routes, which are too long for the BEBs. This creates a challenge for Foothill Transit to expand the size of its BEB fleet and limits the flexibility of operating the current BEBs. The agency is exploring options for meeting these more demanding routes with ZEBs in the future.

On-route chargers - Deploying on-route chargers can be complicated and expensive. An agency needs to find the optimal site for charger installation and may need more than one site to cover multiple routes. A site needs to be off the street to allow time for a bus to fully charge without blocking traffic. The site also needs to have space for charging equipment and access to enough power from the electric grid. Transit centers can be convenient sites, especially if the land is owned by the agency. If not, an agreement with the property owner is required. Installation requires the agency to work with multiple partners including local code officials. An agency also needs to consider how to service and maintain these chargers that are not co-located with existing facilities.

On-route charger availability - For on-route charged buses, availability of the charger is paramount for operating BEBs. Foothill Transit installed two chargers at its Pomona Transit Center to help avoid schedule delays and downtime of the fast-charge BEB fleet. In May 2020, one of the chargers experienced a thermal event that damaged the charger and made it unavailable for use - misalignment of the rooftop charging system and physical damage to electrical contactors caused an arc and ignited a fire during a charging event, taking the charger out of service. Foothill Transit was still able to operate BEBs on the route, using the second charger only. In October 2020, the second charger experienced a similar event, taking the second 
charger out of service. At that time, the agency was forced to park the fast-charge BEB fleet and service the route with $\mathrm{CNG}$ buses until the chargers were repaired and returned to service in late January 2021. These incidents highlight the critical role of charger availability in successfully operating BEBs.

Coordination with charger installation and bus delivery — One of the biggest challenges Foothill Transit experienced with deploying its BEB 40E2 fleet was planning and installation of the charging infrastructure at the Arcadia facility. Delays in planning and construction resulted in the buses being delivered before the charging infrastructure was completed. The agency could not reliably charge the full fleet of BEBs after they were received, and therefore could not deploy the BEBs in service. Although delivery of the buses began in 2017, the agency was not able to put the entire fleet in full service until the beginning of 2020, after the chargers were fully commissioned. Prior to that time, some of the buses were used for training and limited service and were charged using other available chargers at the facility.

\subsection{Recommendations for Agencies Considering BEBs}

Foothill Transit has gained valuable experience in deploying BEBs. The agency highlights the following key recommendations for other agencies when considering deployment of BEBs:

- Conduct a full analysis of routes to identify the energy requirements to meet service. Use the data collected to model the number of BEBs that would be required. Some routes will be well suited for the current capabilities of electric buses and others might require midday charging or more buses. Understand that HVAC use lowers the effective range in warmer and cooler months and take this into account when planning service. Also consider battery degradation over time to determine if a particular BEB can meet service as it ages.

- Design and develop the infrastructure based on the route analysis to ensure you can charge the buses effectively.

- Work with the local utility to install charging infrastructure and address potential costs for demand and time-of-use charges. Start discussions with the utility early in the planning process.

- Consider redundant chargers for on-route charged buses to avoid downtime.

- Plan for cost and operational impacts when adding new technology buses. Agencies need to train staff, including operators, maintenance technicians, and dispatchers. Develop procedures to ensure BEBs are fully charged in time for service.

- Develop a plan for how to handle meeting service with BEBs during an emergency. Traffic backups can result in depletion of charge before the buses complete routes. Consider how to charge buses during major power outages.

- Monitor BEB performance to help identify potential issues prior to failure and understand how the buses are operating in your service. There are different options to collect and analyze bus performance data. Many OEMs provide solutions for tracking performance. Another option is outfitting buses with data loggers from third-party companies that can collect data on any bus OEM. 
With the arrival of 2 Alexander Dennis double deck electric buses in January 2021, Foothill Transit's fleet of BEBs has grown to 34 buses. The agency continues to work to fully transition its fleet to zero-emission buses and meet state regulations. The agency is exploring options for ZEB technologies to meet the requirements for some of its longer routes which surpass 150miles. Evaluations of fuel cell electric buses (FCEBs) have shown range and operational characteristics similar to CNG buses. Foothill Transit is moving forward with an order of 20 FCEBs and a hydrogen station slated for completion in the third quarter of 2022. Results from these deployments will allow a comparison between the two ZEB technologies and provide data the agency will use in future purchase decisions. 


\section{Glossary}

\section{Term}

Availability

Average driving speed

Clean point

Deadhead

Miles between roadcalls (MBRC)

Revenue service

Roadcall

\section{Definition}

The number of days the buses are available for service compared to the days that the buses are planned for operation, expressed as a percent.

The average speed of the buses while driving, not including stops and idle time. These data are collected using data loggers.

For each evaluation, NREL works with the project partners to determine a starting point — or clean point — for the data analysis period. The clean point is chosen to avoid some of the early and expected operations problems with a new vehicle going into service, such as early maintenance campaigns. In some cases, reaching the clean point may require 3 to 6 months of operation before the evaluation can start.

The miles and hours a vehicle travels when out of revenue service, with no expectation of carrying revenue passengers. Deadhead includes leaving or returning to the garage or yard facility and changing routes.

A measure of reliability calculated by dividing the number of miles traveled by the number of roadcalls. (Also known as mean distance between failures.) MBRC results presented are categorized as follows:

Bus MBRC-Includes all chargeable roadcalls. Includes propulsionrelated issues as well as problems with bus-related systems such as brakes, suspension, steering, windows, doors, and tires.

Propulsion-related $M B R C$-Includes roadcalls attributed to the propulsion system. Propulsion-related roadcalls can be caused by issues with the transmission, batteries, and electric drive.

ESS-related MBRC - Includes roadcalls attributed to the energy storage system (ESS) only.

The time when a vehicle is available to the public with an expectation of carrying fare-paying passengers. Vehicles operated in a fare-free service are also considered revenue service.

A failure of an in-service bus that causes the bus to be replaced on route or causes a significant delay in schedule. The analysis includes chargeable roadcalls that affect the operation of the bus or may cause a safety hazard. Non-chargeable roadcalls can be passenger incidents that require the bus to be cleaned before going back into service, or problems with an accessory such as a farebox or radio. 


\section{Contact Information}

\section{California Air Resources Board}

1001 I Street

P.O. Box 2815

Sacramento, CA 95812

Yachun Chow, Manager, Zero Emission Truck and Bus Section

Phone: 279-203-7449

Email: Yachun.Chow@arb.ca.gov

\section{NREL}

15013 Denver West Parkway

Golden, CO 80401

Matthew Jeffers, Research Engineer, Commercial Vehicle Technologies

Phone: 303-275-3778

Email: matthew.jeffers@,nrel.gov

Leslie Eudy, Senior Project Leader, Commercial Vehicle Technologies

Phone: 303-275-4412

Email: leslie.eudy@,nrel.gov

\section{Foothill Transit}

100 S. Vincent Ave.

Suite 200

West Covina, CA 91790

Roland Cordero, Director of Maintenance and Vehicle Technology

Phone: 626-931-7246

Email: rcordero@,foothilltransit.org

\section{Proterra}

1 Whitley Court

Greenville, SC 29607

Mike Finnern, Customer Service Director

Phone: 864-214-0393

Email: MFinnern@,Proterra.com 


\title{
Appendix A. Related NREL Reports
}

\author{
All NREL zero-emission bus evaluation reports can be downloaded from the following \\ website: https://www.nrel.gov/hydrogen/fuel-cell-bus-evaluation.html
}

Eudy, L.; Prohaska, R.; Kelley, K.; Post, M. (2016). Foothill Transit Battery Electric Bus Demonstration Results. NREL/TP-5400-65274. Golden, CO: National Renewable Energy Laboratory. http://www.nrel.gov/docs/fy16osti/65274.pdf.

Eudy, L.; Jeffers M. (2017). Foothill Transit Battery Electric Bus Demonstration Results: Second Report. NREL/TP-5400-67698. Golden, CO: National Renewable Energy Laboratory. http://www.nrel.gov/docs/fy17osti/67698.pdf.

Eudy, L.; Jeffers M. (2018). Foothill Transit Agency Battery Electric Bus Progress Report-Data Period Focus: Jan. 2017 through Dec. 2017. NREL/PR-5400-71292. Golden, CO: National Renewable Energy Laboratory. http://www.nrel.gov/docs/fy18osti/71292.pdf.

Eudy, L.; Jeffers M. (2018). Foothill Transit Agency Battery Electric Bus Progress Report-Data Period Focus: Jan. 2018 through Jun. 2018. NREL/PR-5400-72207. Golden, CO: National Renewable Energy Laboratory. http://www.nrel.gov/docs/fy19osti/72207.pdf.

Eudy, L.; Jeffers M. (2019). Foothill Transit Agency Battery Electric Bus Progress Report-Data Period Focus: Jul. 2018 through Dec. 2018. NREL/PR-5400-72209. Golden, CO: National Renewable Energy Laboratory. http://www.nrel.gov/docs/fy19osti/72209.pdf.

Eudy, L.; Jeffers M. (2019). Foothill Transit Agency Battery Electric Bus Progress Report-Data Period Focus: Jan. 2019 through Jun. 2019. NREL/PR-5400-73516. Golden, CO: National Renewable Energy Laboratory. http://www.nrel.gov/docs/fy20osti/73516.pdf.

Eudy, L.; Jeffers M. (2020). Foothill Transit Agency Battery Electric Bus Progress Report-Data Period Focus: Jul. 2019 through Dec. 2019. NREL/PR-5400-75581. Golden, CO: National Renewable Energy Laboratory. https:/www.nrel.gov/docs/fy20osti/75581.pdf.

Eudy, L.; Jeffers M. (2020). Foothill Transit Agency Battery Electric Bus Progress Report-Data Period Focus: Jan. 2020 through June 2020. NREL/PR-5400-76259. Golden, CO: National Renewable Energy Laboratory. http://www.nrel.gov/docs/fy21osti/76259.pdf. 


\section{Appendix B. Analysis Notes}

1. To compare the BEB electrical energy $(\mathrm{kWh})$ to $\mathrm{CNG}$ fuel energy (reported in gasoline gallon equivalent, gge), both energy sources were converted to diesel gallon equivalent (dge) based on the energy content of each fuel. ${ }^{10}$ The energy conversion factors used in this evaluation were derived as follows:

Lower heating value $(\mathrm{LHV})$ for diesel $=128,488 \mathrm{Btu} / \mathrm{gal}_{\text {diesel }}$

Energy content of electricity $=3,414 \mathrm{Btu} / \mathrm{kWh}$

LHV for gasoline $=112,114 \mathrm{Btu} /$ gal $_{\text {gasoline }}$.

Conversion factor for electricity to diesel gallon equivalent (dge):

$$
\left(128,488 \mathrm{Btu} / \mathrm{gal}_{\text {diesel }}\right) /(3,414 \mathrm{Btu} / \mathrm{kWh})=37.6356 \mathrm{kWh} / \mathrm{gal}_{\text {diesel }}
$$

Conversion factor for $\mathrm{CNG}$ fuel (in gge) to diesel gallon equivalent (dge):

$$
\left(128,488 \mathrm{Btu} / \mathrm{gal}_{\text {diesel }}\right) /\left(112,114 \mathrm{Btu} / \mathrm{gal}_{\text {gasoline }}\right)=1.1460 \mathrm{gal} \text { gasoline }_{\text {gal }} / l_{\text {diesel }}
$$

2. The propulsion-related systems were chosen to include only those systems of the vehicles that could be affected directly by the selection of a fuel or advanced technology.

3. American Trucking Associations (ATA) Vehicle Maintenance Reporting Standards (VMRS) coding is based on parts that were replaced. If there was no part replaced in a given repair, then the code was selected based on the system being worked on.

4. In general, inspections (with no part replacements) were included only in the overall totals (not by system). Category 101 was created to track labor costs for PMIs.

5. ATA VMRS 02-Cab and Sheet Metal represents seats, doors, etc.; ATA VMRS 50Accessories represents fire extinguishers, test kits, fareboxes, etc.; ATA VMRS 71-Body represents mostly windows and windshields.

6. Average labor cost is assumed to be $\$ 50$ per hour for consistency with previous transit ZEB evaluations. This does not necessarily reflect an average labor rate for Foothill Transit.

7. Warranty costs are not included in the maintenance costs analysis.

\footnotetext{
${ }^{10}$ Alternative Fuels Data Center, "Fuel Properties Comparison,"
} http://www.afdc.energy.gov/fuels/fuel_properties.php 


\section{Appendix C. Fleet Summary Statistics, Pomona}

\section{C.1 Pomona Operations and Economics}

\begin{tabular}{|c|c|c|c|c|c|c|}
\hline & $\begin{array}{l}\text { BEB 35FC } \\
\text { All Data }\end{array}$ & $\begin{array}{l}\text { BEB 35FC } \\
2020\end{array}$ & $\begin{array}{l}\text { BEB 40FC } \\
\text { All Data }\end{array}$ & $\begin{array}{l}\text { BEB 40FC } \\
2020\end{array}$ & $\begin{array}{c}\text { CNG } \\
\text { All Data }\end{array}$ & $\begin{array}{l}\text { CNG } \\
2020\end{array}$ \\
\hline Number of vehicles & 12 & 12 & 2 & 2 & 8 & 8 \\
\hline $\begin{array}{l}\text { Period used for fuel and } \\
\text { energy operation analysis }\end{array}$ & $\begin{array}{l}4 / 2014- \\
12 / 2020\end{array}$ & $\begin{array}{l}1 / 2020- \\
12 / 2020\end{array}$ & $\begin{array}{l}1 / 2017- \\
12 / 2020\end{array}$ & $\begin{array}{l}1 / 2020- \\
12 / 2020\end{array}$ & $\begin{array}{r}10 / 2014- \\
12 / 2020\end{array}$ & $\begin{array}{l}1 / 2020 \\
12 / 2020\end{array}$ \\
\hline $\begin{array}{l}\text { Total number of months in } \\
\text { period }\end{array}$ & 82 & 12 & 48 & 12 & 75 & 12 \\
\hline $\begin{array}{l}\text { Fuel and energy analysis } \\
\text { base fleet mileage }\end{array}$ & $1,728,036$ & 70,088 & 79,918 & 15,801 & $2,439,422$ & 315,809 \\
\hline $\begin{array}{l}\text { Period used for } \\
\text { maintenance analysis }\end{array}$ & $\begin{array}{l}1 / 2015- \\
12 / 2020\end{array}$ & $\begin{array}{l}1 / 2020 \\
12 / 2020\end{array}$ & $\begin{array}{l}1 / 2017- \\
12 / 2020\end{array}$ & $\begin{array}{l}1 / 2020 \\
12 / 2020\end{array}$ & $\begin{array}{r}10 / 2014- \\
12 / 2020\end{array}$ & $\begin{array}{l}1 / 2020 \\
12 / 2020\end{array}$ \\
\hline $\begin{array}{l}\text { Total number of months in } \\
\text { period }\end{array}$ & 73 & 12 & 48 & 12 & 75 & 12 \\
\hline $\begin{array}{l}\text { Maintenance analysis base } \\
\text { fleet mileage }\end{array}$ & $1,575,505$ & 70,088 & 153,005 & 15,801 & $2,763,746$ & 392,900 \\
\hline $\begin{array}{l}\text { Average monthly mileage } \\
\text { per vehicle }\end{array}$ & 1,885 & 531 & 1,594 & 658 & 4,606 & 4,093 \\
\hline Availability (\%) & 80.6 & 64.6 & 76.1 & 61.0 & 94.0 & 88.8 \\
\hline $\begin{array}{l}\text { Fleet energy usage (kWh } \\
\text { for BEB; gge for CNG) }\end{array}$ & $3,722,506.0$ & $139,374.1$ & $167,461.4$ & $30,963.1$ & $651,404.3$ & $88,908.9$ \\
\hline Roadcalls & 312 & 17 & 19 & 2 & 110 & 19 \\
\hline Total MBRC & 5,680 & 4,123 & 8,053 & 7,901 & 25,125 & 20,679 \\
\hline Propulsion roadcalls & 132 & 11 & 9 & 2 & 73 & 14 \\
\hline Propulsion MBRC & 13,425 & 6,372 & 17,001 & 7,901 & 37,860 & 28,064 \\
\hline $\begin{array}{l}\text { Fleet kWh/mile (BEB) or } \\
\text { miles/gge (CNG) }\end{array}$ & 2.15 & 1.99 & 2.10 & 1.96 & 3.74 & 3.55 \\
\hline $\begin{array}{l}\text { Representative fleet mpg } \\
\text { (diesel energy equiv.) }\end{array}$ & 17.47 & 18.93 & 17.96 & 19.21 & 4.29 & 4.07 \\
\hline $\begin{array}{l}\text { Energy cost per kWh (CNG } \\
\text { cost per gge) }\end{array}$ & 0.180 & 0.199 & 0.180 & 0.199 & 1.05 & 1.33 \\
\hline $\begin{array}{l}\text { Energy/fuel cost per mile } \\
\text { (based on purchased } \\
\text { energy) }\end{array}$ & 0.44 & 0.64 & 0.44 & 0.64 & 0.28 & 0.37 \\
\hline $\begin{array}{l}\text { Total scheduled repair cost } \\
\text { per mile }\end{array}$ & 0.07 & 0.07 & 0.07 & 0.04 & 0.11 & 0.10 \\
\hline $\begin{array}{l}\text { Total unscheduled repair } \\
\text { cost per mile }\end{array}$ & 0.43 & 1.53 & 0.49 & 1.26 & 0.21 & 0.40 \\
\hline $\begin{array}{l}\text { Total maintenance cost per } \\
\text { mile }\end{array}$ & 0.50 & 1.59 & 0.56 & 1.30 & 0.32 & 0.50 \\
\hline $\begin{array}{l}\text { Total operating cost per } \\
\text { mile }\end{array}$ & 0.94 & 2.23 & 1.01 & 1.93 & 0.60 & 0.87 \\
\hline
\end{tabular}




\section{C.2 Pomona Maintenance Costs Overview}

\begin{tabular}{|c|c|c|c|c|c|c|}
\hline & $\begin{array}{l}\text { BEB 35FC } \\
\text { All Data }\end{array}$ & $\begin{array}{l}\text { BEB 35FC } \\
2020\end{array}$ & $\begin{array}{l}\text { BEB 40FC } \\
\text { All Data }\end{array}$ & $\begin{array}{l}\text { BEB 40FC } \\
2020\end{array}$ & $\begin{array}{c}\text { CNG } \\
\text { All Data }\end{array}$ & $\begin{array}{l}\text { CNG } \\
2020\end{array}$ \\
\hline Fleet mileage & $1,575,505$ & 70,088 & 153,005 & 15,801 & $2,763,746$ & 392,900 \\
\hline Total parts cost & $381,516.31$ & $42,323.60$ & $34,797.64$ & $7,668.33$ & $473,181.40$ & $107,366.01$ \\
\hline Total labor hours & $8,127.5$ & $1,384.3$ & $1,029.5$ & 256.1 & $8,212.1$ & $1,801.6$ \\
\hline Total labor cost (at $\$ 50 /$ hour) & $406,375.50$ & $69,213.50$ & $51,475.50$ & $12,804.50$ & $410,603.00$ & $90,077.50$ \\
\hline Total maintenance cost & $787,891.81$ & $111,537.10$ & $86,273.14$ & $20,472.83$ & $883,784.40$ & $197,443.51$ \\
\hline $\begin{array}{l}\text { Total maintenance cost per } \\
\text { bus }\end{array}$ & $65,657.65$ & $9,294.76$ & $43,136.57$ & $10,236.42$ & $110,473.05$ & $24,680.44$ \\
\hline $\begin{array}{l}\text { Total maintenance cost per } \\
\text { mile }\end{array}$ & 0.500 & 1.591 & 0.564 & 1.296 & 0.320 & 0.503 \\
\hline
\end{tabular}




\begin{tabular}{|c|c|c|c|c|c|c|}
\hline & $\begin{array}{l}\text { BEB 35FC } \\
\text { All Data }\end{array}$ & $\begin{array}{c}\text { BEB 35FC } \\
2020\end{array}$ & $\begin{array}{l}\text { BEB 40FC } \\
\text { All Data }\end{array}$ & $\begin{array}{c}\text { BEB 40FC } \\
2020\end{array}$ & $\begin{array}{c}\text { CNG } \\
\text { All Data }\end{array}$ & $\begin{array}{l}\text { CNG } \\
2020\end{array}$ \\
\hline Fleet mileage & $1,575,505$ & 70,088 & 153,005 & 15,801 & $2,763,746$ & 392,900 \\
\hline \multicolumn{7}{|c|}{ Total Engine/Fuel-Related Systems (ATA VMRS 27, 30, 31, 32, 33, 41, 42, 43, 44, 45, 46, 65) } \\
\hline Parts cost & $161,183.76$ & $18,237.12$ & $17,078.84$ & $6,835.69$ & $247,864.34$ & $53,364.13$ \\
\hline Labor hours & $2,517.38$ & 685.41 & 346.73 & 136.97 & $2,377.22$ & 684.61 \\
\hline Total labor cost & $125,869.00$ & $34,270.50$ & $17,336.50$ & $6,848.50$ & $118,861.00$ & $34,230.50$ \\
\hline Total cost & $287,052.76$ & $52,507.62$ & $34,415.34$ & $13,684.19$ & $366,725.34$ & $87,594.63$ \\
\hline Total cost per bus & $23,921.06$ & $4,375.64$ & $17,207.67$ & $6,842.10$ & $45,840.67$ & $10,949.33$ \\
\hline Total system cost per mile & 0.182 & 0.749 & 0.225 & 0.866 & 0.133 & 0.223 \\
\hline \multicolumn{7}{|c|}{ Exhaust System Repairs (ATA VMRS 43) } \\
\hline Parts cost & 0.00 & 0.00 & 0.00 & 0.00 & $23,432.18$ & $4,559.94$ \\
\hline Labor hours & 0.0 & 0.0 & 0.0 & 0.0 & 88.6 & 22.1 \\
\hline Total labor cost & 0.00 & 0.00 & 0.00 & 0.00 & $4,428.00$ & $1,102.50$ \\
\hline Total cost & 0.00 & 0.00 & 0.00 & 0.00 & $27,860.18$ & $5,662.44$ \\
\hline Total cost per bus & 0.00 & 0.00 & 0.00 & 0.00 & $3,482.52$ & 707.81 \\
\hline Total system cost per mile & 0.000 & 0.000 & 0.000 & 0.000 & 0.010 & 0.014 \\
\hline \multicolumn{7}{|c|}{ Fuel System Repairs (ATA VMRS 44) } \\
\hline Parts cost & 0.00 & 0.00 & 0.00 & 0.00 & $8,792.13$ & $1,701.34$ \\
\hline Labor hours & 0.0 & 0.0 & 0.0 & 0.0 & 149.0 & 33.1 \\
\hline Total labor cost & 0.00 & 0.00 & 0.00 & 0.00 & $7,448.50$ & $1,654.50$ \\
\hline Total cost & 0.00 & 0.00 & 0.00 & 0.00 & $16,240.63$ & $3,355.84$ \\
\hline Total cost per bus & 0.00 & 0.00 & 0.00 & 0.00 & $2,030.08$ & 419.48 \\
\hline Total system cost per mile & 0.000 & 0.000 & 0.000 & 0.000 & 0.006 & 0.009 \\
\hline \multicolumn{7}{|c|}{ Power Plant (Engine or ESS) Repairs (ATA VMRS 45) } \\
\hline Parts cost & 56.34 & 0.00 & 0.00 & 0.00 & $72,173.20$ & $8,357.07$ \\
\hline Labor hours & 248.5 & 91.8 & 13.2 & 0.5 & 756.4 & 242.8 \\
\hline Total labor cost & $12,425.50$ & $4,590.50$ & 660.00 & 25.00 & $37,819.00$ & $12,140.00$ \\
\hline Total cost & $12,481.84$ & $4,590.50$ & 660.00 & 25.00 & $109,992.20$ & $20,497.07$ \\
\hline Total cost per bus & $1,040.15$ & 382.54 & 330.00 & 12.50 & $13,749.03$ & $2,562.13$ \\
\hline Total system cost per mile & 0.008 & 0.065 & 0.004 & 0.002 & 0.040 & 0.052 \\
\hline \multicolumn{7}{|c|}{ Electric Propulsion Repairs (ATA VMRS 46) } \\
\hline Parts cost & $72,260.80$ & 488.14 & $2,336.64$ & $2,336.64$ & 0.00 & 0.00 \\
\hline Labor hours & 637.1 & 292.8 & 171.7 & 76.3 & 0.0 & 0.0 \\
\hline Total labor cost & $31,855.00$ & $14,639.00$ & $8,585.00$ & $3,812.50$ & 0.00 & 0.00 \\
\hline Total cost & $104,115.80$ & $15,127.14$ & $10,921.64$ & $6,149.14$ & 0.00 & 0.00 \\
\hline Total cost per bus & $8,676.32$ & $1,260.60$ & $5,460.82$ & $3,074.57$ & 0.00 & 0.00 \\
\hline Total system cost per mile & 0.066 & 0.216 & 0.071 & 0.389 & 0.000 & 0.000 \\
\hline
\end{tabular}




\begin{tabular}{|c|c|c|c|c|c|c|}
\hline & $\begin{array}{c}\text { BEB 35FC } \\
\text { All Data }\end{array}$ & $\begin{array}{c}\text { BEB 35FC } \\
2020\end{array}$ & $\begin{array}{c}\text { BEB 40FC } \\
\text { All Data }\end{array}$ & $\begin{array}{c}\text { BEB 40FC } \\
2020\end{array}$ & $\begin{array}{c}\text { CNG } \\
\text { All Data }\end{array}$ & $\begin{array}{l}\text { CNG } \\
2020\end{array}$ \\
\hline \multicolumn{7}{|c|}{ Electrical System Repairs (ATA VMRS 30-Electrical General, 31-Charging, 32-Cranking, 33-Ignition) } \\
\hline Parts cost & $76,656.60$ & $11,758.93$ & $14,243.80$ & $4,491.93$ & $73,573.38$ & $26,026.85$ \\
\hline Labor hours & 1147.8 & 191.2 & 131.0 & 45.5 & 584.9 & 124.6 \\
\hline Total labor cost & $57,391.00$ & $9,562.00$ & $6,548.00$ & $2,272.50$ & $29,245.00$ & $6,230.50$ \\
\hline Total cost & $134,047.60$ & $21,320.93$ & $20,791.80$ & $6,764.43$ & $102,818.38$ & $32,257.35$ \\
\hline Total cost per bus & $11,170.63$ & $1,776.74$ & $10,395.90$ & $3,382.22$ & $12,852.30$ & $4,032.17$ \\
\hline Total system cost per mile & 0.085 & 0.304 & 0.136 & 0.428 & 0.037 & 0.082 \\
\hline \multicolumn{7}{|c|}{ Air Intake System Repairs (ATA VMRS 41) } \\
\hline Parts cost & 115.70 & 7.50 & 6.20 & 0.00 & $24,696.82$ & $3,039.26$ \\
\hline Labor hours & 3.9 & 0.0 & 0.0 & 0.0 & 16.5 & 6.7 \\
\hline Total labor cost & 195.00 & 0.00 & 0.00 & 0.00 & 823.00 & 334.00 \\
\hline Total cost & 310.70 & 7.50 & 6.20 & 0.00 & $25,519.82$ & $3,373.26$ \\
\hline Total cost per bus & 25.89 & 0.63 & 3.10 & 0.00 & $3,189.98$ & 421.66 \\
\hline Total system cost per mile & 0.000 & 0.000 & 0.000 & 0.000 & 0.009 & 0.009 \\
\hline \multicolumn{7}{|c|}{ Cooling System Repairs (ATA VMRS 42) } \\
\hline Parts cost & $4,307.51$ & 0.00 & 485.08 & 0.00 & $29,480.42$ & $6,626.84$ \\
\hline Labor hours & 116.5 & 0.0 & 16.1 & 0.0 & 601.7 & 180.0 \\
\hline Total labor cost & $5,827.00$ & 0.00 & 805.00 & 0.00 & $30,086.50$ & $9,000.50$ \\
\hline Total cost & $10,134.51$ & 0.00 & $1,290.08$ & 0.00 & $59,566.92$ & $15,627.34$ \\
\hline Total cost per bus & 844.54 & 0.00 & 645.04 & 0.00 & $7,445.86$ & $1,953.42$ \\
\hline Total system cost per mile & 0.006 & 0.000 & 0.008 & 0.000 & 0.022 & 0.040 \\
\hline \multicolumn{7}{|c|}{ Hydraulic System Repairs (ATA VMRS 65) } \\
\hline Parts cost & 0.00 & 0.00 & 0.00 & 0.00 & 126.03 & 0.00 \\
\hline Labor hours & 2.0 & 0.0 & 0.0 & 0.0 & 1.0 & 0.0 \\
\hline Total labor cost & 97.50 & 0.00 & 0.00 & 0.00 & 50.00 & 0.00 \\
\hline Total cost & 97.50 & 0.00 & 0.00 & 0.00 & 176.03 & 0.00 \\
\hline Total cost per bus & 8.13 & 0.00 & 0.00 & 0.00 & 22.00 & 0.00 \\
\hline Total system cost per mile & 0.000 & 0.000 & 0.000 & 0.000 & 0.000 & 0.000 \\
\hline \multicolumn{7}{|c|}{ General Air System Repairs (ATA VMRS 10) } \\
\hline Parts cost & $38,815.93$ & 589.40 & $1,288.77$ & 28.41 & $6,152.00$ & $2,056.21$ \\
\hline Labor hours & 371.4 & 16.2 & 135.2 & 20.4 & 97.2 & 29.3 \\
\hline Total labor cost & $18,569.00$ & 807.50 & $6,761.50$ & $1,021.00$ & $4,859.50$ & $1,462.50$ \\
\hline Total cost & $57,384.93$ & $1,396.90$ & $8,050.27$ & $1,049.41$ & $11,011.50$ & $3,518.71$ \\
\hline Total cost per bus & $4,782.08$ & 116.41 & $4,025.14$ & 524.71 & $1,376.44$ & 439.84 \\
\hline Total system cost per mile & 0.036 & 0.020 & 0.053 & 0.066 & 0.004 & 0.009 \\
\hline
\end{tabular}




\begin{tabular}{|c|c|c|c|c|c|c|}
\hline & $\begin{array}{l}\text { BEB 35FC } \\
\text { All Data }\end{array}$ & $\begin{array}{l}\text { BEB 35FC } \\
2020\end{array}$ & $\begin{array}{l}\text { BEB 40FC } \\
\text { All Data }\end{array}$ & $\begin{array}{l}\text { BEB 40FC } \\
2020\end{array}$ & $\begin{array}{c}\text { CNG } \\
\text { All Data }\end{array}$ & $\begin{array}{l}\text { CNG } \\
2020\end{array}$ \\
\hline \multicolumn{7}{|c|}{ Brake System Repairs (ATA VMRS 13) } \\
\hline Parts cost & $7,380.17$ & $4,337.13$ & 0.00 & 0.00 & $26,688.72$ & $6,838.23$ \\
\hline Labor hours & 229.5 & 119.0 & 14.4 & 1.2 & 478.5 & 137.4 \\
\hline Total labor cost & $11,474.50$ & $5,950.50$ & 717.50 & 58.50 & $23,923.00$ & $6,869.00$ \\
\hline Total cost & $18,854.67$ & $10,287.63$ & 717.50 & 58.50 & $50,611.72$ & $13,707.23$ \\
\hline Total cost per bus & $1,571.22$ & 857.30 & 358.75 & 29.25 & $6,326.47$ & $1,713.40$ \\
\hline Total system cost per mile & 0.012 & 0.147 & 0.005 & 0.004 & 0.018 & 0.035 \\
\hline \multicolumn{7}{|c|}{ Transmission Repairs (ATA VMRS 27) } \\
\hline Parts cost & $7,786.81$ & $5,982.55$ & 7.12 & 7.12 & $15,590.18$ & $3,052.83$ \\
\hline Labor hours & 361.6 & 109.6 & 14.8 & 14.8 & 179.2 & 75.4 \\
\hline Total labor cost & $18,078.00$ & $5,479.00$ & 738.50 & 738.50 & $8,961.00$ & $3,768.50$ \\
\hline Total cost & $25,864.81$ & $11,461.55$ & 745.62 & 745.62 & $24,551.18$ & $6,821.33$ \\
\hline Total cost per bus & $2,155.40$ & 955.13 & 372.81 & 372.81 & $3,068.90$ & 852.67 \\
\hline Total system cost per mile & 0.016 & 0.164 & 0.005 & 0.047 & 0.009 & 0.017 \\
\hline \multicolumn{7}{|c|}{ Inspections Only - No Parts Replacements (101) } \\
\hline Parts cost & 0.00 & 0.00 & 0.00 & 0.00 & 0.00 & 0.00 \\
\hline Labor hours & 2240.8 & 71.5 & 191.6 & 6.1 & 2861.7 & 295.1 \\
\hline Total labor cost & $112,039.00$ & $3,574.00$ & $9,578.50$ & 306.50 & $143,085.00$ & $14,753.00$ \\
\hline Total cost & $112,039.00$ & $3,574.00$ & $9,578.50$ & 306.50 & $143,085.00$ & $14,753.00$ \\
\hline Total cost per bus & $9,336.58$ & 297.83 & $4,789.25$ & 153.25 & $17,885.63$ & $1,844.13$ \\
\hline Total system cost per mile & 0.071 & 0.051 & 0.063 & 0.019 & 0.052 & 0.038 \\
\hline \multicolumn{7}{|c|}{$\begin{array}{l}\text { Cab, Body, and Accessories Systems Repairs (ATA VMRS 02-Cab and Sheet Metal, 50-Accessories, 71- } \\
\text { Body) }\end{array}$} \\
\hline Parts cost & $40,425.94$ & $7,167.47$ & $4,209.32$ & 0.00 & $62,144.09$ & $17,400.91$ \\
\hline Labor hours & 1614.0 & 215.5 & 257.9 & 76.0 & 1608.2 & 420.0 \\
\hline Total labor cost & $80,701.50$ & $10,773.00$ & $12,896.00$ & $3,799.00$ & $80,410.00$ & $20,999.50$ \\
\hline Total cost & $121,127.44$ & $17,940.47$ & $17,105.32$ & $3,799.00$ & $142,554.09$ & $38,400.41$ \\
\hline Total cost per bus & $10,093.95$ & $1,495.04$ & $8,552.66$ & $1,899.50$ & $17,819.26$ & $4,800.05$ \\
\hline Total system cost per mile & 0.077 & 0.256 & 0.112 & 0.240 & 0.052 & 0.098 \\
\hline \multicolumn{7}{|c|}{ HVAC System Repairs (ATA VMRS 01) } \\
\hline Parts cost & $10,095.31$ & $2,528.80$ & 166.29 & 7.50 & $18,522.54$ & $6,054.66$ \\
\hline Labor hours & 303.9 & 147.4 & 24.3 & 11.4 & 152.0 & 39.7 \\
\hline Total labor cost & $15,196.50$ & $7,372.00$ & $1,216.00$ & 569.00 & $7,599.50$ & $1,985.50$ \\
\hline Total cost & $25,291.81$ & $9,900.80$ & $1,382.29$ & 576.50 & $26,122.04$ & $8,040.16$ \\
\hline Total cost per bus & $2,107.65$ & 825.07 & 691.15 & 288.25 & $3,265.26$ & $1,005.02$ \\
\hline Total system cost per mile & 0.016 & 0.141 & 0.009 & 0.036 & 0.009 & 0.020 \\
\hline
\end{tabular}




\begin{tabular}{|c|c|c|c|c|c|c|}
\hline & $\begin{array}{l}\text { BEB 35FC } \\
\text { All Data }\end{array}$ & $\begin{array}{l}\text { BEB 35FC } \\
2020\end{array}$ & $\begin{array}{l}\text { BEB 40FC } \\
\text { All Data }\end{array}$ & $\begin{array}{l}\text { BEB 40FC } \\
2020\end{array}$ & $\begin{array}{l}\text { CNG } \\
\text { All Data }\end{array}$ & $\begin{array}{l}\text { CNG } \\
2020\end{array}$ \\
\hline \multicolumn{7}{|c|}{ Lighting System Repairs (ATA VMRS 34) } \\
\hline Parts cost & $4,808.03$ & 239.85 & 369.30 & 6.73 & $1,625.77$ & $1,003.55$ \\
\hline Labor hours & 296.0 & 60.9 & 25.4 & 2.0 & 106.0 & 48.5 \\
\hline Total labor cost & $14,799.50$ & $3,042.50$ & $1,270.50$ & 98.50 & $5,300.00$ & $2,423.50$ \\
\hline Total cost & $19,607.53$ & $3,282.35$ & $1,639.80$ & 105.23 & $6,925.77$ & $3,427.05$ \\
\hline Total cost per bus & $1,633.96$ & 273.53 & 819.90 & 52.62 & 865.72 & 428.38 \\
\hline Total system cost per mile & 0.012 & 0.047 & 0.011 & 0.007 & 0.003 & 0.009 \\
\hline \multicolumn{7}{|c|}{ Frame, Steering, and Suspension Repairs (ATA VMRS 14-Frame, 15-Steering, 16-Suspension) } \\
\hline Parts cost & $9,725.95$ & $3,357.50$ & 331.52 & 0.00 & $11,567.29$ & $2,542.57$ \\
\hline Labor hours & 246.7 & 35.5 & 3.1 & 0.0 & 153.1 & 54.7 \\
\hline Total labor cost & $12,336.50$ & $1,776.00$ & 155.50 & 0.00 & $7,654.50$ & $2,737.00$ \\
\hline Total cost & $22,062.45$ & $5,133.50$ & 487.02 & 0.00 & $19,221.79$ & $5,279.57$ \\
\hline Total cost per bus & $1,838.54$ & 427.79 & 243.51 & 0.00 & $2,402.72$ & 659.95 \\
\hline Total system cost per mile & 0.014 & 0.073 & 0.003 & 0.000 & 0.007 & 0.013 \\
\hline \multicolumn{7}{|c|}{$\begin{array}{l}\text { Axle, Wheel, and Drive Shaft Repairs (ATA VMRS 11-Front Axle, 18-Wheels, 22-Rear Axle, 24-Drive } \\
\text { Shaft) }\end{array}$} \\
\hline Parts cost & $2,229.23$ & 336.33 & 799.69 & 0.00 & $27,046.02$ & $1,469.51$ \\
\hline Labor hours & 25.4 & 8.9 & 10.1 & 0.0 & 118.1 & 36.9 \\
\hline Total labor cost & $1,270.00$ & 442.50 & 503.50 & 0.00 & $5,906.00$ & $1,843.50$ \\
\hline Total cost & $3,499.23$ & 778.83 & $1,303.19$ & 0.00 & $32,952.02$ & $3,313.01$ \\
\hline Total cost per bus & 291.60 & 64.90 & 651.60 & 0.00 & $4,119.00$ & 414.13 \\
\hline Total system cost per mile & 0.002 & 0.011 & 0.009 & 0.000 & 0.012 & 0.008 \\
\hline \multicolumn{7}{|l|}{ Tire Repairs (ATA VMRS 17) } \\
\hline Parts cost & $100,566.99$ & $5,530.00$ & $10,268.91$ & 790.00 & $68,869.43$ & $16,636.24$ \\
\hline Labor hours & 282.4 & 24.1 & 20.8 & 2.1 & 259.1 & 55.5 \\
\hline Total labor cost & $14,120.00$ & $1,205.00$ & $1,040.00$ & 103.50 & $12,954.50$ & $2,773.50$ \\
\hline Total cost & $114,686.99$ & $6,735.00$ & $11,308.91$ & 893.50 & $81,823.93$ & $19,409.74$ \\
\hline Total cost per bus & $9,557.25$ & 561.25 & $5,654.46$ & 446.75 & $10,227.99$ & $2,426.22$ \\
\hline Total system cost & 0.073 & 0.096 & 0.074 & 0.057 & 0.030 & 0.049 \\
\hline \multicolumn{7}{|l|}{ Tow Charges } \\
\hline Parts cost & $6,285.00$ & 0.00 & 285.00 & 0.00 & $2,701.20$ & 0.00 \\
\hline Labor hours & 0.00 & 0.00 & 0.00 & 0.00 & 1.0 & 0.0 \\
\hline Total labor cost & 0.00 & 0.00 & 0.00 & 0.00 & 50.00 & 0.00 \\
\hline Total cost & $6,285.00$ & 0.00 & 285.00 & 0.00 & $2,751.20$ & 0.00 \\
\hline Total cost per bus & 523.75 & 0.00 & 142.50 & 0.00 & 343.90 & 0.00 \\
\hline Total system cost per mile & 0.004 & 0.000 & 0.002 & 0.000 & 0.001 & 0.000 \\
\hline
\end{tabular}




\section{Appendix D. Fleet Summary Statistics, Pomona-SI Units}

\section{D.1 Pomona Operations and Economics}

\begin{tabular}{|c|c|c|c|c|c|c|}
\hline & $\begin{array}{l}\text { BEB 35FC } \\
\text { All Data }\end{array}$ & $\begin{array}{l}\text { BEB 35FC } \\
2020\end{array}$ & $\begin{array}{l}\text { BEB 40FC } \\
\text { All Data }\end{array}$ & $\begin{array}{l}\text { BEB 40FC } \\
2020\end{array}$ & $\begin{array}{c}\text { CNG } \\
\text { All Data }\end{array}$ & $\begin{array}{l}\text { CNG } \\
2020\end{array}$ \\
\hline Number of vehicles & 12 & 12 & 2 & 2 & 8 & 8 \\
\hline $\begin{array}{l}\text { Period used for fuel and } \\
\text { energy analysis }\end{array}$ & $\begin{array}{l}4 / 2014- \\
12 / 2020\end{array}$ & $\begin{array}{l}1 / 2020- \\
12 / 2020\end{array}$ & $\begin{array}{l}1 / 2017- \\
12 / 2020\end{array}$ & $\begin{array}{l}1 / 2020- \\
12 / 2020\end{array}$ & $\begin{array}{r}10 / 2014- \\
2 / 2020\end{array}$ & $\begin{array}{l}1 / 2020 \\
12 / 2020\end{array}$ \\
\hline $\begin{array}{l}\text { Total number of months in } \\
\text { period }\end{array}$ & 82 & 12 & 48 & 12 & 75 & 12 \\
\hline $\begin{array}{l}\text { Fuel and energy analysis } \\
\text { base fleet kilometers }\end{array}$ & $2,780,929$ & 112,792 & 128,612 & 25,429 & $3,925,762$ & 508,231 \\
\hline $\begin{array}{l}\text { Period used for } \\
\text { maintenance analysis }\end{array}$ & $\begin{array}{l}1 / 2015- \\
12 / 2020\end{array}$ & $\begin{array}{l}1 / 2020- \\
12 / 2020\end{array}$ & $\begin{array}{l}1 / 2017- \\
12 / 2020\end{array}$ & $\begin{array}{l}1 / 2020- \\
12 / 2020\end{array}$ & $\begin{array}{r}10 / 2014- \\
12 / 2020\end{array}$ & $\begin{array}{l}1 / 2020 \\
12 / 2020\end{array}$ \\
\hline $\begin{array}{l}\text { Total number of months in } \\
\text { period }\end{array}$ & 73 & 12 & 48 & 12 & 75 & 12 \\
\hline $\begin{array}{l}\text { Maintenance analysis base } \\
\text { fleet kilometers }\end{array}$ & $2,535,461$ & 112,792 & 246,231 & 25,429 & $4,447,696$ & 632,294 \\
\hline $\begin{array}{l}\text { Average monthly kilometers } \\
\text { per vehicle }\end{array}$ & 3,034 & 854 & 2,565 & 1,060 & 7,413 & 6,586 \\
\hline Availability & 81 & 65 & 76 & 61 & 94 & 89 \\
\hline $\begin{array}{l}\text { Fleet fuel usage in } \\
\text { kWh/CNG liter equiv. }\end{array}$ & $3,722,506$ & 139,374 & 167,461 & 30,963 & $2,465,834$ & 336,557 \\
\hline Roadcalls & 312 & 17 & 19 & 2 & 110 & 19 \\
\hline Total KMBRCa & 9,140 & 6,635 & 12,960 & 12,714 & 40,434 & 33,279 \\
\hline Propulsion roadcalls & 132 & 11 & 9 & 2 & 73 & 14 \\
\hline Propulsion KMBRC & 21,605 & 10,254 & 27,359 & 12,714 & 60,927 & 45,164 \\
\hline $\begin{array}{l}\text { Rep. fleet fuel consumption } \\
(\mathrm{L} / 100 \mathrm{~km})\end{array}$ & 13.44 & 12.41 & 13.07 & 12.22 & 56.22 & 59.27 \\
\hline $\begin{array}{l}\text { Energy cost per kWh (CNG } \\
\text { cost/liter) }\end{array}$ & 0.18 & 0.20 & 0.18 & 0.20 & 0.28 & 0.35 \\
\hline $\begin{array}{l}\text { Energy/fuel cost per } \\
\text { kilometer (based on } \\
\text { purchased energy) }\end{array}$ & 0.28 & 0.40 & 0.28 & 0.40 & 0.17 & 0.23 \\
\hline $\begin{array}{l}\text { Total scheduled repair cost } \\
\text { per kilometer }\end{array}$ & 0.05 & 0.02 & 0.04 & 0.00 & 0.07 & 0.03 \\
\hline $\begin{array}{l}\text { Total unscheduled repair } \\
\text { cost per kilometer }\end{array}$ & 0.26 & 0.42 & 0.31 & 0.36 & 0.13 & 0.14 \\
\hline $\begin{array}{l}\text { Total maintenance cost per } \\
\text { kilometer }\end{array}$ & 0.31 & 0.44 & 0.35 & 0.36 & 0.20 & 0.17 \\
\hline $\begin{array}{l}\text { Total operating cost per } \\
\text { kilometer }\end{array}$ & 0.59 & 0.83 & 0.63 & 0.76 & 0.37 & 0.40 \\
\hline
\end{tabular}

a Kilometers between roadcalls 


\section{D.2 Pomona Maintenance Costs}

\begin{tabular}{|c|c|c|c|c|c|c|}
\hline & $\begin{array}{l}\text { BEB 35FC } \\
\text { All Data }\end{array}$ & $\begin{array}{l}\text { BEB 35FC } \\
2020\end{array}$ & $\begin{array}{l}\text { BE40FC } \\
\text { All Data }\end{array}$ & $\begin{array}{l}\text { BEB 40FC } \\
2020\end{array}$ & $\begin{array}{c}\text { CNG } \\
\text { All Data }\end{array}$ & $\begin{array}{l}\text { CNG } \\
2020\end{array}$ \\
\hline Fleet mileage & $2,535,461$ & 112,792 & 246,231 & 25,429 & $4,447,696$ & 632,294 \\
\hline Total parts cost & $381,516.31$ & $42,323.60$ & $34,797.64$ & $7,668.33$ & $473,181.40$ & $107,366.01$ \\
\hline Total labor hours & $8,127.51$ & $1,384.27$ & $1,029.51$ & 256.09 & $8,212.06$ & $1,801.55$ \\
\hline $\begin{array}{l}\text { Average labor cost (at } \\
\$ 50.00 \text { per hour) }\end{array}$ & $406,375.50$ & $69,213.50$ & $51,475.50$ & $12,804.50$ & $410,603.00$ & $90,077.50$ \\
\hline Total maintenance cost & $787,891.81$ & $111,537.10$ & $86,273.14$ & $20,472.83$ & $883,784.40$ & $197,443.51$ \\
\hline $\begin{array}{l}\text { Total maintenance cost } \\
\text { per bus }\end{array}$ & $65,657.65$ & $9,294.76$ & $43,136.57$ & $10,236.42$ & $110,473.05$ & $24,680.44$ \\
\hline $\begin{array}{l}\text { Total maintenance } \\
\text { cost per kilometer }\end{array}$ & 0.31 & 0.99 & 0.35 & 0.81 & 0.20 & 0.31 \\
\hline
\end{tabular}




\section{Appendix E. Fleet Summary Statistics, Arcadia}

\section{E.1 Arcadia Operations and Economics}

\begin{tabular}{|l|r|r|}
\hline & $\begin{array}{c}\text { BEB 40E2 } \\
\text { All Data }\end{array}$ & $\begin{array}{c}\text { CNG } \\
\text { Number of vehicles }\end{array}$ \\
\hline Period used for fuel and energy analysis & 14 & 14 \\
\hline Total number of months in period & $1 / 2020-12 / 2020$ & $1 / 2020-12 / 2020$ \\
\hline Fuel and energy analysis base fleet mileage & 12 & 12 \\
\hline Period used for maintenance analysis & 507,619 & 34,389 \\
\hline Total number of months in period & $1 / 2020-12 / 2020$ & $1 / 2020-12 / 2020$ \\
\hline Maintenance analysis base fleet mileage & 12 & 12 \\
\hline Average monthly mileage per vehicle & 507,619 & 787,353 \\
\hline Availability (\%) & 3,022 & 4,687 \\
\hline Fleet energy usage in kWh for BEB (gge for CNG) & 81.9 & 93.5 \\
\hline Roadcalls & 966,606 & $10,164.47$ \\
\hline Total MBRC & 22 & 32 \\
\hline Propulsion roadcalls & 23,074 & 24,605 \\
\hline Propulsion MBRC & 15 & 25 \\
\hline Fleet kWh/mile (BEB) or miles/gge (CNG) & 33,841 & 31,494 \\
\hline Representative fleet mpg (diesel energy equiv.) & 1.90 & 3.38 \\
\hline Energy cost per kWh (CNG cost per gge) & 19.76 & 3.88 \\
\hline Energy/fuel cost per mile (based on purchased energy) & 0.188 & 1.27 \\
\hline Total scheduled repair cost per mile & 0.42 & 0.37 \\
\hline Total unscheduled repair cost per mile & 0.07 & 0.12 \\
\hline Total maintenance cost per mile & 0.29 & 0.24 \\
\hline Total operating cost per mile & 0.36 & 0.35 \\
\hline & 0.78 & $\mathbf{0 . 7 2}$ \\
\hline
\end{tabular}

\section{E.2 Arcadia Maintenance Costs}

\begin{tabular}{|l|r|r|} 
& \multicolumn{1}{|c|}{$\begin{array}{c}\text { BEB 40E2 } \\
\text { All Data }\end{array}$} & \multicolumn{1}{c|}{$\begin{array}{c}\text { CNG } \\
\text { All Data }\end{array}$} \\
\hline Fleet mileage & 507,615 & 787,353 \\
\hline Total parts cost & $61,394.23$ & $119,711.72$ \\
\hline Total labor hours & $2,466.0$ & $3,180.1$ \\
\hline Total labor cost $($ at $\$ 50.00$ per hour) & $123,299.00$ & $159,002.50$ \\
\hline Total maintenance cost & $184,693.23$ & $278,714.22$ \\
\hline Total maintenance cost per bus & $13,192.37$ & $19,908.16$ \\
\hline Total maintenance cost per mile & $\mathbf{0 . 3 6 4}$ & $\mathbf{0 . 3 5 4}$ \\
\hline
\end{tabular}




\section{E.3 Arcadia Breakdown of Maintenance Costs by Vehicle System}

\begin{tabular}{|c|c|c|}
\hline & $\begin{array}{c}\text { BEB 40E2 } \\
\text { All Data }\end{array}$ & $\begin{array}{c}\text { CNG } \\
\text { All Data }\end{array}$ \\
\hline Fleet mileage & 507,615 & 787,353 \\
\hline \multicolumn{3}{|c|}{ Total Engine/Fuel-Related Systems (ATA VMRS 27, 30, 31, 32, 33, 41, 42, 43, 44, 45, 46, 65) } \\
\hline Parts cost & $15,400.44$ & $55,420.73$ \\
\hline Labor hours & 719.97 & 785.01 \\
\hline Total labor cost & $35,998.50$ & $39,250.50$ \\
\hline Total cost & $51,398.94$ & $94,671.23$ \\
\hline Total cost per bus & $3,671.35$ & $6,762.23$ \\
\hline Total system cost per mile & 0.101 & 0.120 \\
\hline \multicolumn{3}{|c|}{ Exhaust System Repairs (ATA VMRS 43) } \\
\hline Parts cost & 0.00 & $2,932.27$ \\
\hline Labor hours & 0.0 & 46.3 \\
\hline Total labor cost & 0.00 & $2,316.50$ \\
\hline Total cost & 0.00 & $5,248.77$ \\
\hline Total cost per bus & 0.00 & 374.91 \\
\hline Total system cost per mile & 0.000 & 0.007 \\
\hline \multicolumn{3}{|c|}{ Fuel System Repairs (ATA VMRS 44) } \\
\hline Parts cost & 0.00 & $10,402.65$ \\
\hline Labor hours & 0.0 & 87.3 \\
\hline Total labor cost & 0.00 & $4,367.00$ \\
\hline Total cost & 0.00 & $14,769.65$ \\
\hline Total cost per bus & 0.00 & $1,054.98$ \\
\hline Total system cost per mile & 0.000 & 0.019 \\
\hline \multicolumn{3}{|c|}{ Power Plant (Engine or ESS) Repairs (ATA VMRS 45) } \\
\hline Parts cost & 814.00 & $14,750.00$ \\
\hline Labor hours & 65.5 & 203.9 \\
\hline Total labor cost & $3,272.50$ & $10,195.50$ \\
\hline Total cost & $4,086.50$ & $24,945.50$ \\
\hline Total cost per bus & 291.89 & $1,781.82$ \\
\hline Total system cost per mile & 0.008 & 0.032 \\
\hline \multicolumn{3}{|c|}{ Electric Propulsion Repairs (ATA VMRS 46) } \\
\hline Parts cost & 719.45 & 0.00 \\
\hline Labor hours & 182.3 & 0.0 \\
\hline Total labor cost & $9,112.50$ & 0.00 \\
\hline Total cost & $9,831.95$ & 0.00 \\
\hline Total cost per bus & 702.28 & 0.00 \\
\hline Total system cost per mile & 0.019 & 0.000 \\
\hline
\end{tabular}




\begin{tabular}{|c|c|c|}
\hline & $\begin{array}{c}\text { BEB 40E2 } \\
\text { All Data }\end{array}$ & $\begin{array}{c}\text { CNG } \\
\text { All Data }\end{array}$ \\
\hline \multicolumn{3}{|c|}{ Electrical System Repairs (ATA VMRS 30-Electrical General, 31-Charging, 32-Cranking, 33-Ignition) } \\
\hline Parts cost & $10,369.51$ & $19,809.79$ \\
\hline Labor hours & 166.9 & 157.1 \\
\hline Total labor cost & $8,344.50$ & $7,856.00$ \\
\hline Total cost & $18,714.01$ & $27,665.79$ \\
\hline Total cost per bus & $1,336.72$ & $1,976.13$ \\
\hline Total system cost per mile & 0.037 & 0.035 \\
\hline \multicolumn{3}{|c|}{ Air Intake System Repairs (ATA VMRS 41) } \\
\hline Parts cost & 115.04 & $2,835.40$ \\
\hline Labor hours & 0.0 & 7.8 \\
\hline Total labor cost & 0.00 & 392.00 \\
\hline Total cost & 115.04 & $3,227.40$ \\
\hline Total cost per bus & 8.22 & 230.53 \\
\hline Total system cost per mile & 0.000 & 0.004 \\
\hline \multicolumn{3}{|c|}{ Cooling System Repairs (ATA VMRS 42) } \\
\hline Parts cost & $3,382.44$ & $2,459.48$ \\
\hline Labor hours & 199.5 & 258.8 \\
\hline Total labor cost & $9,975.00$ & $12,941.50$ \\
\hline Total cost & $13,357.44$ & $15,400.98$ \\
\hline Total cost per bus & 954.10 & $1,100.07$ \\
\hline Total system cost per mile & 0.026 & 0.020 \\
\hline \multicolumn{3}{|c|}{ Hydraulic System Repairs (ATA VMRS 65) } \\
\hline Parts cost & 0.00 & 11.19 \\
\hline Labor hours & 0.0 & 0.0 \\
\hline Total labor cost & 0.00 & 0.00 \\
\hline Total cost & 0.00 & 11.19 \\
\hline Total cost per bus & 0.00 & 0.80 \\
\hline Total system cost per mile & 0.000 & 0.000 \\
\hline \multicolumn{3}{|c|}{ General Air System Repairs (ATA VMRS 10) } \\
\hline Parts cost & $6,857.01$ & $2,873.00$ \\
\hline Labor hours & 129.2 & 50.6 \\
\hline Total labor cost & $6,460.00$ & $2,532.00$ \\
\hline Total cost & $13,317.01$ & $5,405.00$ \\
\hline Total cost per bus & 951.22 & 386.07 \\
\hline Total system cost per mile & 0.026 & 0.007 \\
\hline
\end{tabular}




\begin{tabular}{|c|c|c|}
\hline & $\begin{array}{l}\text { BEB 40E2 } \\
\text { All Data }\end{array}$ & $\begin{array}{l}\text { CNG } \\
\text { All Data }\end{array}$ \\
\hline \multicolumn{3}{|c|}{ Brake System Repairs (ATA VMRS 13) } \\
\hline Parts cost & 0.00 & $4,731.41$ \\
\hline Labor hours & 41.6 & 205.9 \\
\hline Total labor cost & $2,079.00$ & $10,292.50$ \\
\hline Total cost & $2,079.00$ & $15,023.91$ \\
\hline Total cost per bus & 148.50 & $1,073.14$ \\
\hline Total system cost per mile & 0.004 & 0.019 \\
\hline \multicolumn{3}{|c|}{ Transmission Repairs (ATA VMRS 27) } \\
\hline Parts cost & 0.00 & $2,219.95$ \\
\hline Labor hours & 105.9 & 23.6 \\
\hline Total labor cost & $5,294.00$ & $1,182.00$ \\
\hline Total cost & $5,294.00$ & $3,401.95$ \\
\hline Total cost per bus & 378.14 & 243.00 \\
\hline Total system cost per mile & 0.010 & 0.004 \\
\hline \multicolumn{3}{|c|}{ Inspections Only - No Parts Replacements (101) } \\
\hline Parts cost & 0.00 & 0.00 \\
\hline Labor hours & 678.2 & 1027.7 \\
\hline Total labor cost & $33,910.50$ & $51,384.50$ \\
\hline Total cost & $33,910.50$ & $51,384.50$ \\
\hline Total cost per bus & $2,422.18$ & $3,670.32$ \\
\hline Total system cost per mile & 0.067 & 0.065 \\
\hline \multicolumn{3}{|c|}{$\begin{array}{l}\text { Cab, Body, and Accessories Systems Repairs (ATA VMRS 02-Cab and Sheet Metal, 50- } \\
\text { Accessories, 71-Body) }\end{array}$} \\
\hline Parts cost & $5,494.03$ & $5,773.96$ \\
\hline Labor hours & 545.3 & 603.1 \\
\hline Total labor cost & $27,265.50$ & $30,155.00$ \\
\hline Total cost & $32,759.53$ & $35,928.96$ \\
\hline Total cost per bus & $2,339.97$ & $2,566.35$ \\
\hline Total system cost per mile & 0.065 & 0.046 \\
\hline \multicolumn{3}{|c|}{ HVAC System Repairs (ATA VMRS 01) } \\
\hline Parts cost & 355.38 & $6,426.52$ \\
\hline Labor hours & 133.4 & 109.0 \\
\hline Total labor cost & $6,671.00$ & $5,449.00$ \\
\hline Total cost & $7,026.38$ & $11,875.52$ \\
\hline Total cost per bus & 501.88 & 848.25 \\
\hline Total system cost per mile & 0.014 & 0.015 \\
\hline
\end{tabular}




\begin{tabular}{|c|c|c|}
\hline & $\begin{array}{l}\text { BEB 40E2 } \\
\text { All Data }\end{array}$ & $\begin{array}{l}\text { CNG } \\
\text { All Data }\end{array}$ \\
\hline \multicolumn{3}{|c|}{ Lighting System Repairs (ATA VMRS 34) } \\
\hline Parts cost & $2,210.74$ & $4,003.76$ \\
\hline Labor hours & 57.8 & 29.0 \\
\hline Total labor cost & $2,889.50$ & $1,448.50$ \\
\hline Total cost & $5,100.24$ & $5,452.26$ \\
\hline Total cost per bus & 364.30 & 389.45 \\
\hline Total system cost per mile & 0.010 & 0.007 \\
\hline \multicolumn{3}{|c|}{ Frame, Steering, and Suspension Repairs (ATA VMRS 14-Frame, 15-Steering, 16-Suspension) } \\
\hline Parts cost & 727.04 & $14,932.98$ \\
\hline Labor hours & 83.0 & 274.4 \\
\hline Total labor cost & $4,149.00$ & $13,718.50$ \\
\hline Total cost & $4,876.04$ & $28,651.48$ \\
\hline Total cost per bus & 348.29 & $2,046.53$ \\
\hline Total system cost per mile & 0.010 & 0.036 \\
\hline \multicolumn{3}{|c|}{$\begin{array}{l}\text { Axle, Wheel, and Drive Shaft Repairs (ATA VMRS 11-Front Axle, 18-Wheels, 22-Rear Axle, 24-Drive } \\
\text { Shaft) }\end{array}$} \\
\hline Parts cost & $1,140.60$ & 608.81 \\
\hline Labor hours & 19.0 & 12.2 \\
\hline Total labor cost & 947.50 & 611.50 \\
\hline Total cost & $2,088.10$ & $1,220.31$ \\
\hline Total cost per bus & 149.15 & 87.17 \\
\hline Total system cost per mile & 0.004 & 0.002 \\
\hline \multicolumn{3}{|l|}{ Tire Repairs (ATA VMRS 17) } \\
\hline Parts cost & $29,208.99$ & $24,940.55$ \\
\hline Labor hours & 58.6 & 83.2 \\
\hline Total labor cost & $2,928.50$ & $4,160.50$ \\
\hline Total cost & $32,137.49$ & $29,101.05$ \\
\hline Total cost per bus & $2,295.54$ & $2,078.65$ \\
\hline Total system cost per mile & 0.063 & 0.037 \\
\hline
\end{tabular}




\section{Appendix F. Fleet Summary Statistics, Arcadia-SI Units}

\section{F.1 Arcadia Operations and Economics}

\begin{tabular}{|l|r|r|}
\hline & \multicolumn{2}{|c|}{ BEB 40 CNG } \\
\hline Number of vehicles & 14 & 14 \\
\hline Period used for fuel and energy analysis & $1 / 2020-12 / 2020$ & $1 / 2020-12 / 2020$ \\
\hline Total number of months in period & 12 & 12 \\
\hline Fuel and energy analysis base fleet kilometers & 816,910 & 55,342 \\
\hline Period used for maintenance analysis & $1 / 2020-12 / 2020$ & $1 / 2020-12 / 2020$ \\
\hline Total number of months in period & 12 & 12 \\
\hline Maintenance analysis base fleet kilometers & 816,910 & $1,267,087$ \\
\hline Average monthly kilometers per vehicle & 4,863 & 7,542 \\
\hline Availability (\%) & 82 & 94 \\
\hline Fleet fuel usage in kWh (CNG liter equivalent) & 966,606 & 38,477 \\
\hline Roadcalls & 22 & 32 \\
\hline Total KMBRC & 37,132 & 39,596 \\
\hline Propulsion roadcalls & 15 & 25 \\
\hline Propulsion KMBRC & 54,461 & 50,683 \\
\hline Rep. fleet fuel consumption (L/100 km) & 11.88 & 62.22 \\
\hline Energy cost per kWh (CNG cost/liter) & 0.19 & 0.34 \\
\hline Energy/fuel cost per kilometer (based on purchased energy) & $\mathbf{0 . 2 6}$ & $\mathbf{0 . 2 3}$ \\
\hline Total scheduled repair cost per kilometer & 0.04 & 0.05 \\
\hline Total unscheduled repair cost per kilometer & 0.18 & 0.15 \\
\hline Total maintenance cost per kilometer & $\mathbf{0 . 2 3}$ & $\mathbf{0 . 2 2}$ \\
\hline Total operating cost per kilometer & $\mathbf{0 . 4 8}$ & $\mathbf{0 . 4 5}$ \\
\hline
\end{tabular}

\section{F.2 Arcadia Maintenance Costs}

\begin{tabular}{|l|r|r|}
\hline Fleet mileage & \multicolumn{1}{|c|}{$\begin{array}{c}\text { BEB 40E2 } \\
\text { All Data }\end{array}$} & \multicolumn{1}{c|}{ CNG } \\
\hline All Data \\
\hline Total parts cost & 816,906 & $1,267,087$ \\
\hline Total labor hours & $61,394.23$ & $119,711.72$ \\
\hline Total labor cost $($ at $\$ 50.00$ per hour) & $2,465.98$ & $3,180.05$ \\
\hline Total maintenance cost & $123,299.00$ & $159,002.50$ \\
\hline Total maintenance cost per bus & $184,693.23$ & $278,714.22$ \\
\hline Total maintenance cost per kilometer & $13,192.37$ & $19,908.16$ \\
\hline
\end{tabular}

